\title{
Corrective Measures Evaluation Report for Technical Area-V Groundwater
}

Jonathan L. Witt; M. Hope Howard; Kevin A. Hall; Brennon R. Orr; Dana L. Dettmers

Prepared by

Sandia National Laboratories

Albuquerque, New Mexico 87185 and Livermore, California 94550

Sandia is a multiprogram laboratory operated by Sandia Corporation,

a Lockheed Martin Company, for the United States Department of Energy's

National Nuclear Security Administration under Contract DE-AC04-94AL85000.

Approved for public release; further dissemination unlimited.

\section{Iit Sandia National Laboratories}


Issued by Sandia National Laboratories, operated for the United States Department of Energy by Sandia Corporation.

NOTICE: This report was prepared as an account of work sponsored by an agency of the United States Government. Neither the United States Government, nor any agency thereof, nor any of their employees, nor any of their contractors, subcontractors, or their employees, make any warranty, express or implied, or assume any legal liability or responsibility for the accuracy, completeness, or usefulness of any information, apparatus, product, or process disclosed, or represent that its use would not infringe privately owned rights. Reference herein to any specific commercial product, process, or service by trade name, trademark, manufacturer, or otherwise, does not necessarily constitute or imply its endorsement, recommendation, or favoring by the United States Government, any agency thereof, or any of their contractors or subcontractors. The views and opinions expressed herein do not necessarily state or reflect those of the United States Government, any agency thereof, or any of their contractors.

Printed in the United States of America. This report has been reproduced directly from the best available copy.

Available to DOE and DOE contractors from

U.S. Department of Energy

Office of Scientific and Technical Information

P.O. Box 62

Oak Ridge, TN 37831

Telephone: (865) 576-8401

Facsimile: (865) 576-5728

E-Mail: reports@adonis.osti.gov

Online ordering: http://www.doe.gov/bridge

Available to the public from

U.S. Department of Commerce

National Technical Information Service

5285 Port Royal Rd

Springfield, VA 22161

Telephone: (800) 553-6847

Facsimile: (703) 605-6900

E-Mail: orders@ntis.fedworld.gov

Online order: http://www.ntis.gov/help/ordermethods.asp?loc=7-4-0\#online 


\title{
Corrective Measures Evaluation Report For Technical Area-V Groundwater
}

\author{
Jonathan L. Witt; M. Hope Howard; \\ Kevin A. Hall; Brennon R. Orr; Dana L. Dettmers \\ North Wind, Inc. \\ Idaho Falls, Idaho
}

\begin{abstract}
This Corrective Measures Evaluation Report was prepared as directed by the Compliance Order on Consent issued by the New Mexico Environment Department to document the process of selecting the preferred remedial alternative for contaminated groundwater at Technical Area V. Supporting information includes background information about the site conditions and potential receptors and an overview of work performed during the Corrective Measures Evaluation. Evaluation of remedial alternatives included identification and description of four remedial alternatives, an overview of the evaluation criteria and approach, qualitative and quantitative evaluation of remedial alternatives, and selection of the preferred remedial alternative. As a result of the Corrective Measures Evaluation, it was determined that monitored natural attenuation of all contaminants of concern (trichloroethene, tetrachloroethene, and nitrate) was the preferred remedial alternative for implementation as the corrective measure to remediate contaminated groundwater at Technical Area V of Sandia National Laboratories/New Mexico. Finally, design criteria to meet cleanup goals and objectives and the corrective measures implementation schedule for the preferred remedial alternative are presented.
\end{abstract}


This Page Intentionally Left Blank 


\section{Contents}

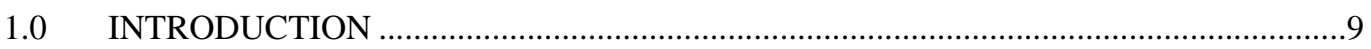

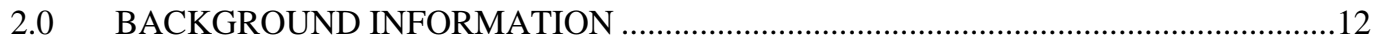

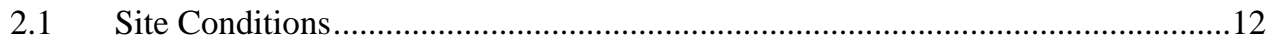

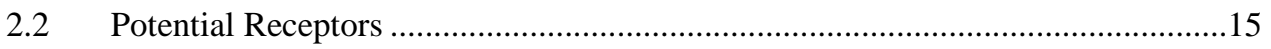

3.0 EVALUATION OF REMEDIAL ALTERNATIVES ....................................................16

3.1 Overview of the Corrective Measures Evaluation ...................................................16

3.1.1 Remedial Alternatives Data Gaps Review.................................................. 19

3.1.2 Evaluation of Contaminant Transport in Groundwater ............................. 20

3.1.3 Investigation of Intrinsic Anaerobic Biodegradation................................. 21

3.1.4 Evaluation of an Intrinsic Aerobic Biodegradation Mechanism................ 21

3.2 Identification and Description of Remedial Alternatives ......................................22

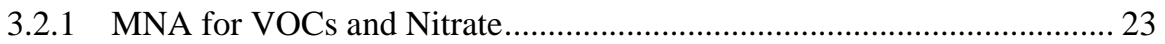

3.2.2 ISB for VOCs and Nitrate and MNA for VOCs ........................................ 26

3.3 Overview of Evaluation Criteria and Approach ......................................................29

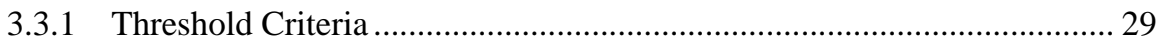

3.3.2 Remedial Alternative Criteria .................................................................... 30

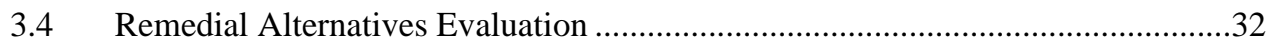

3.5 Selection of a Preferred Remedial Alternative ......................................................34

4.0 REMEDIAL ALTERNATIVE DESIGN CRITERIA TO MEET CLEANUP GOALS

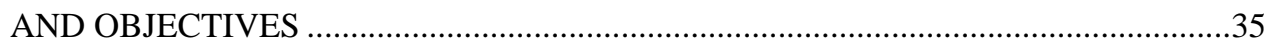

4.1 Performance Goals and Objectives...........................................................................35

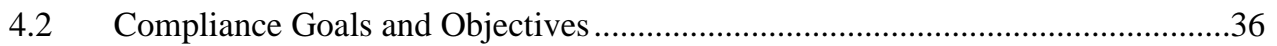

5.0 CORRECTIVE MEASURES IMPLEMENTATION PLAN ...............................................37

$5.1 \quad$ Corrective Measures Implementation Plan Outline ...................................................37

5.2 Corrective Measures Implementation Schedule ……..............................................38

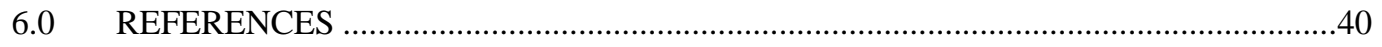


Attachment A. Conceptual Model Update: Contaminant Distribution in Groundwater

Attachment B. Remedial Alternatives Data Gaps Review

Attachment C. Evaluation of Contaminant Transport in Groundwater

Attachment D. Investigation of Contaminant Biodegradation

Attachment E. Evaluation of an Intrinsic Aerobic Degradation Mechanism

\section{Figures}

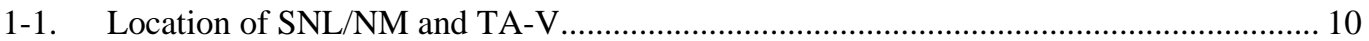

2-1. TCE concentration in TA-V groundwater (May 2003). ...................................................... 14

3-1. Illustration of the process of devising remedial alternatives. ............................................. 17

3-2. Illustration of the staged process of data gathering activities and production of informal

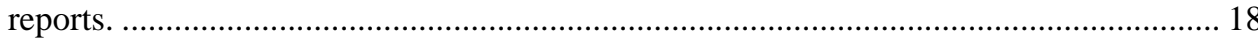

3-3. Changes in remedial alternatives for TA-V groundwater during the Paper Study........... 20

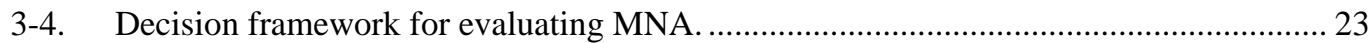

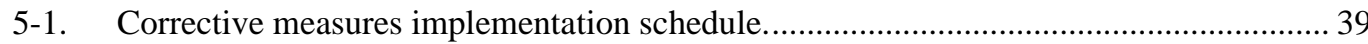

\section{Tables}

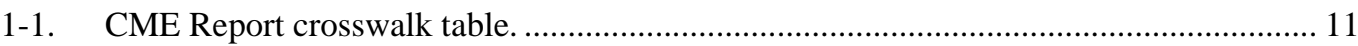

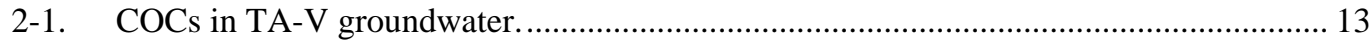

3-1. Outline of documents produced in support of the Corrective Measures Evaluation........ 18

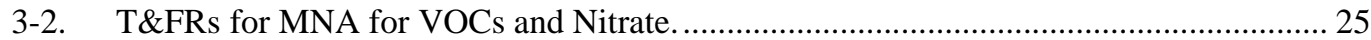

3-3. Itemized costs for the MNA for VOCs and Nitrate remedial alternative. ......................... 26

3-4. T\&FRs for ISB for VOCs and Nitrate and MNA for VOCs. ............................................. 27

3-5. Itemized costs for the ISB and MNA for VOCs and ISB for Nitrate remedial

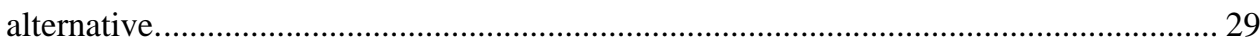

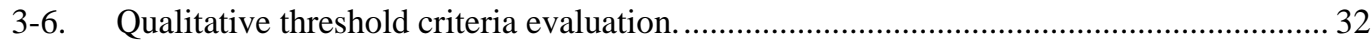

3-7. Quantitative analysis of remedial alternatives for TA-V ................................................. 32

3-8. Information supporting quantitative remedial alternatives evaluation. .............................. 33

5-1. Summary of TA-V documents and delivery dates............................................................... 38 


\section{Acronyms}

\begin{tabular}{|c|c|}
\hline ARD & anaerobic reductive dechlorination \\
\hline ARG & ancestral Rio Grande \\
\hline CME & Corrective Measures Evaluation \\
\hline CMI & Corrective Measures Implementation \\
\hline COA & City of Albuquerque \\
\hline COC & contaminant of concern \\
\hline COOC & Compliance Order on Consent \\
\hline DNA & deoxyribonucleic acid \\
\hline DOE & U.S. Department of Energy \\
\hline EPA & Environmental Protection Agency \\
\hline ER & Environmental Restoration \\
\hline FY & fiscal year \\
\hline ISB & in situ bioremediation \\
\hline KAFB & Kirtland Air Force Base \\
\hline MCL & maximum contaminant level \\
\hline MNA & monitored natural attenuation \\
\hline NMED & New Mexico Environment Department \\
\hline PCE & tetrachloroethene \\
\hline RCRA & Resource Conservation and Recovery Act \\
\hline sMMO & soluble methane monooxygenase \\
\hline SNL/NM & Sandia National Laboratories/New Mexico \\
\hline TA & Technical Area \\
\hline TCE & trichloroethene \\
\hline T\&FR & technical and functional requirement \\
\hline VA & Veterans Administration \\
\hline VOC & volatile organic compound \\
\hline WQCC & Quality Control Commission \\
\hline
\end{tabular}


This Page Intentionally Left Blank 


\subsection{INTRODUCTION}

Sandia National Laboratories, New Mexico (SNL/NM) is a government-owned, contractoroperated, multiprogram laboratory overseen by the U.S. Department of Energy (DOE), National Nuclear Security Administration through the Sandia Site Office, Albuquerque, New Mexico. Sandia Corporation, a wholly-owned subsidiary of Lockheed Martin Corporation, operates SNL/NM under Contract DE-AC04-94AL85000. SNL/NM operates five technical areas (TAs) (i.e., TA-I, TA-II, TA-III, TA-IV, and TA-V) (Figure 1-1). TA-V, which has been operating since the 1960s, is a secured 35-acre research and testing area located immediately northeast of TA-III at SNL/NM. The facility conducts research and development of advanced nuclear reactors, simulation sources, reactor safety, energy-related programs, and nuclear weapons systems.

The SNL/NM Environmental Restoration (ER) Project has reported concentrations of trichloroethene (TCE) exceeding the U.S. Environmental Protection Agency (EPA) maximum contaminant level (MCL) in samples from TA-V monitoring wells since 1993. Since initial discovery of TCE in groundwater, the ER Project has voluntarily undertaken various activities to determine the nature and extent of groundwater contamination, particularly to identify potential sources of this contamination (SNL/NM 1999). Contaminants of concern (COCs) in TA-V groundwater include TCE, tetrachloroethene (PCE), and nitrate.

The New Mexico Environment Department (NMED) issued a Compliance Order on Consent (COOC) (NMED 2004) to the DOE, which among other things identified TA-V as an area of groundwater contamination requiring completion of a Corrective Measures Evaluation (CME). The COOC directed that a CME Work Plan be developed to identify and outline a process to evaluate remedial alternatives for implementation at TA-V. The CME Work Plan was formally approved by the NMED in April 2004 (SNL/NM 2004a). Results of activities performed under the TA-V CME Work Plan are documented in this CME Report.

The purpose of this CME Report is to select a preferred remedial alternative for implementation at TA-V based on the results of information gathered during the CME process. The CME was conducted to ascertain which remedial alternative would most effectively meet the project goals and objectives for cleanup within the regulatory framework. The performance and compliance goals and objectives for TA-V groundwater were developed in the TA-V CME Work Plan (SNL/NM 2004a).

This document is organized in accordance with guidance from the TA-V CME Work Plan (SNL/NM 2004a). Table 1-1 shows a crosswalk of the sections specified by the guidance of the CME Work Plan and the corresponding sections of this document. The Current Conceptual Model of Groundwater Flow and Contaminant Transport at Sandia National Laboratories/New Mexico Technical Area-V (SNL/NM 2004b), referred to in this document as the TA-V Current Conceptual Model, is summarized as background information in Section 2.0. Section 3.0 provides the details for the evaluation of the remedial alternatives. Section 4.0 presents remedial alternative design criteria to meet the cleanup goals and objectives. Section 5.0 presents an outline for the Corrective Measures Implementation (CMI) Plan and forecasts the schedule for CMI. 


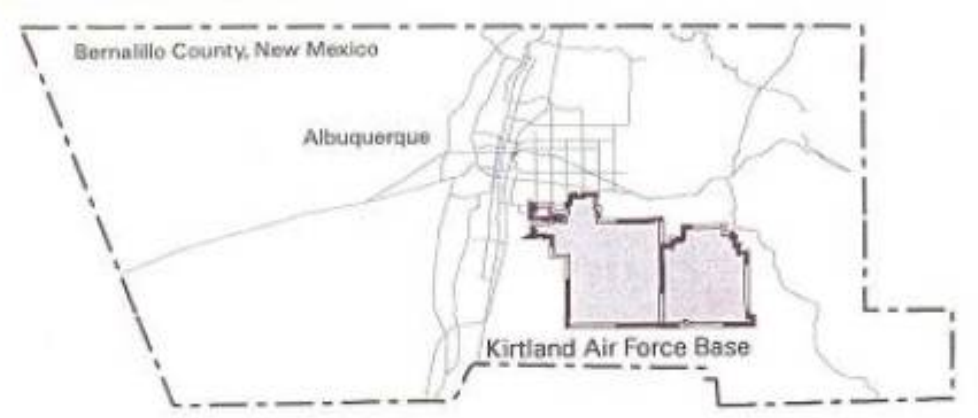

Location Map of Sandia National Laboratories/New Mexico

\& Technical Areas II \& V

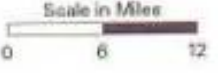

Bernalillo County, New Mexico
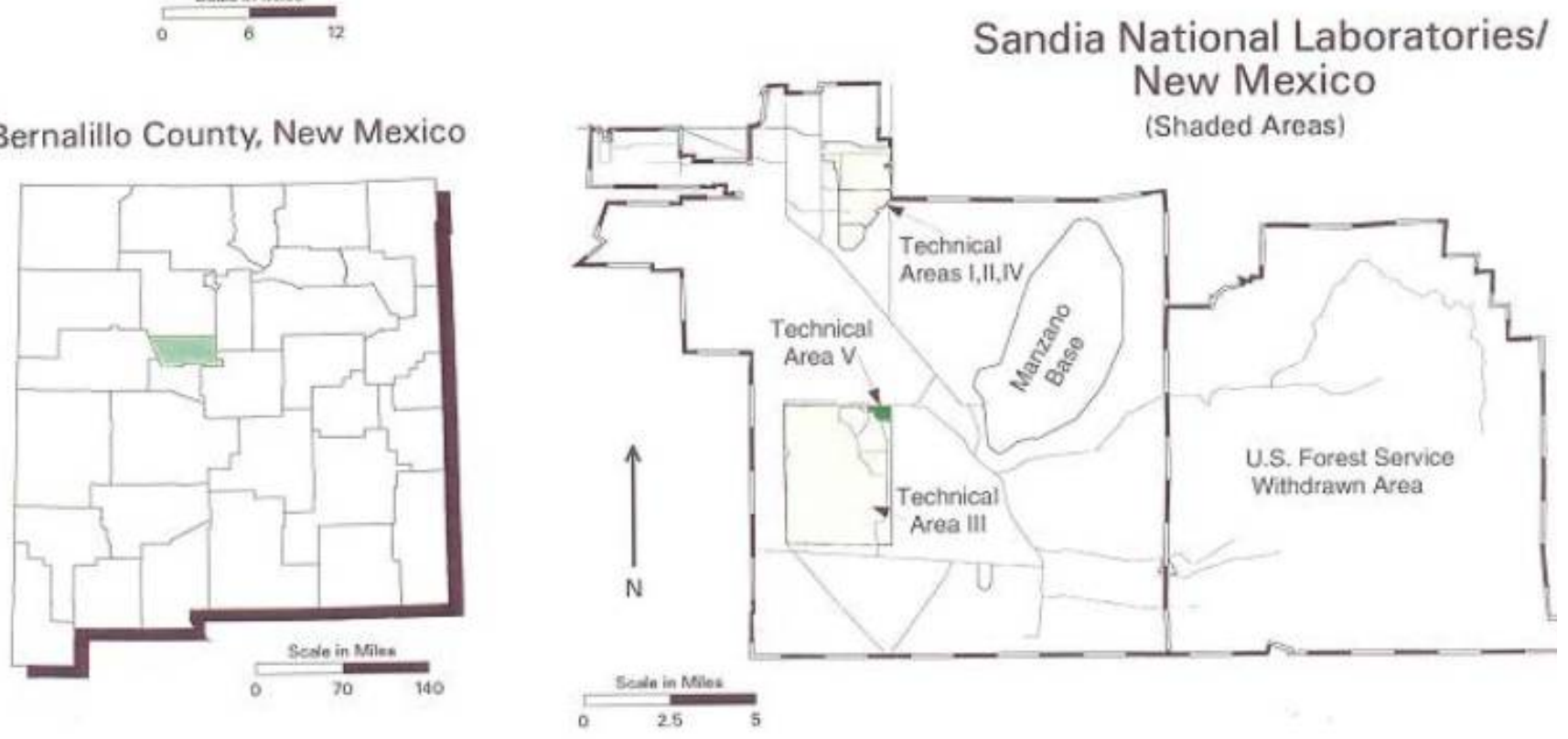

Figure 1-1. Location of SNL/NM and TA-V. 
Table 1-1. CME Report crosswalk table.

\begin{tabular}{l|ll}
$\begin{array}{c}\text { CME Report Requirements } \\
\text { (as stated in the CME Work Plan and } \\
\text { the COOC) }\end{array}$ & \multicolumn{2}{c}{$\begin{array}{c}\text { TA-V CME Report } \\
\text { (Section) }\end{array}$} \\
\hline Introduction & 1.0 & Introduction \\
\hline Background Information & 2.0 & Background Information \\
\hline Site Conditions & 2.1 & Site Conditions \\
\hline Potential Receptors & 2.2 & Potential Receptors \\
\hline Regulatory Criteria & 3.3 & $\begin{array}{l}\text { Overview of Evaluation Criteria and } \\
\text { Approach }\end{array}$ \\
\hline Identification of Remedial Alternatives & 3.2 & $\begin{array}{l}\text { Identification and Description of Remedial } \\
\text { Alternatives }\end{array}$ \\
\hline Evaluation of Remedial Alternatives & 3.0 & Evaluation of Remedial Alternatives \\
\hline $\begin{array}{l}\text { Selection of a Preferred Remedial } \\
\text { Alternative }\end{array}$ & 3.5 & $\begin{array}{l}\text { Selection of a Preferred Remedial } \\
\text { Alternative }\end{array}$ \\
\hline $\begin{array}{l}\text { Design Criteria to Meet Cleanup } \\
\text { Objectives }\end{array}$ & 4.0 & $\begin{array}{l}\text { Remedial Alternative Design Criteria to } \\
\text { Meet Cleanup Objectives }\end{array}$ \\
\hline Schedule & 5.0 & \begin{tabular}{l} 
Schedule \\
\hline
\end{tabular} \\
\hline
\end{tabular}




\subsection{BACKGROUND INFORMATION}

This section provides a summary of the TA-V site conditions and potential receptors. A complete discussion of the TA-V site conditions and potential receptors is found in the TA-V Current Conceptual Model (SNL/NM 2004b).

\subsection{Site Conditions}

The COCs in groundwater at TA-V have been identified based on detections above MCLs in samples collected from monitoring wells. These COCs consist of PCE, TCE, and nitrate. Table 2-1 identifies the COCs for this project and includes the maximum historical concentrations, maximum concentrations observed during a more recent sampling event, and MCLs for each COC. TCE is the most widely distributed COC at TA-V. The extent of TCE contamination is approximately 1,200 ft long and $600 \mathrm{ft}$ wide. Figure 2-1 illustrates the location of the TCE contaminated groundwater at TA-V. The other COCs are distributed over smaller areas within or near the TCE contaminated zone. PCE has been detected in well TAV-MW7 and nitrate has routinely been detected in LWDS-MW1 above the MCL. For evaluation of remedial alternatives, maximum historical values of COCs are used; however, more recent observations demonstrate that the contaminant concentrations are lower.

Attachment A of this CME Report presents time series COC concentration plots, originally presented in the NMED-approved Current Conceptual Model (SNL/NM 2004b), that have been updated with groundwater monitoring data from Fiscal Year (FY)-2003 and FY-04. The most current concentration data show that COCs in TA-V groundwater are not increasing. The extent of TCE, PCE, and nitrate contaminated groundwater is stable (or not expanding) because concentration trends are not increasing in TA-V monitoring wells.

TA-V lies within the Albuquerque Basin of the Rio Grande Rift in north central New Mexico. The Albuquerque Basin is filled with sedimentary deposits of the alluvial fan lithofacies and ancestral Rio Grande (ARG) lithofacies of the Santa Fe Group. The vadose zone at TA-V extends from ground surface to the water table at a depth of approximately $500 \mathrm{ft}$ and consists of heterogeneous, lenticular, coarse- to fine-grained deposits. The underlying aquifer at TA-V consists of fine-grained, clay-rich, alluvial-fan sediments. Groundwater in the vicinity of TA-V flows generally from east to west. As discussed in the "Evaluation of Contaminant Transport in Groundwater" (Attachment C), the rate of groundwater flow at TA-V is estimated to be approximately $20 \mathrm{ft} / \mathrm{yr}$. To the west of TA-V, groundwater flow paths turn to the north in response to pumpage from large municipal well fields north of Kirtland Air Force Base (KAFB). 
Table 2-1. COCs in TA-V groundwater.

\begin{tabular}{|c|c|c|c|}
\hline Contaminant & $\begin{array}{l}\text { Maximum Historical } \\
\text { Concentration } \\
\text { (FY } 2000 \text { to FY 2004) }\end{array}$ & $\begin{array}{c}\text { Maximum Concentration } \\
\text { during a more recent sampling } \\
\text { event (fourth-quarter FY 2004, } \\
\text { SNL/NM 2005a) }\end{array}$ & $\begin{array}{c}\text { Federal Drinking } \\
\text { Water Standard } \\
\text { (MCL) }\end{array}$ \\
\hline \multicolumn{4}{|c|}{ VOLATILE ORGANIC COMPOUNDS } \\
\hline Trichloroethene (TCE) & $26 \mu \mathrm{g} / \mathrm{L}^{\mathrm{a}}$ & $17.9 \mu \mathrm{g} / \mathrm{L}^{\mathrm{c}}$ & $5 \mu \mathrm{g} / \mathrm{L}^{\mathrm{e}}$ \\
\hline Tetrachloroethene (PCE) & $7.5 \mu \mathrm{g} / \mathrm{L}^{\mathrm{b}}$ & $<0.33 \mu \mathrm{g} / \mathrm{L}^{\mathrm{d}}$ & $5 \mu \mathrm{g} / \mathrm{L}^{\mathrm{e}}$ \\
\hline \multicolumn{4}{|l|}{ INORGANIC CHEMICAL } \\
\hline Nitrate (as nitrogen) & $19 \mathrm{mg} / \mathrm{L}^{\mathrm{a}}$ & $12.2 \mathrm{mg} / \mathrm{L}^{\mathrm{c}}$ & $10 \mathrm{mg} / \mathrm{L}^{\mathrm{f}}$ \\
\hline \multicolumn{4}{|l|}{$\begin{array}{l}\mu \mathrm{g} / \mathrm{L}=\text { micrograms per liter } \\
\mathrm{mg} / \mathrm{L}=\text { milligrams per liter }\end{array}$} \\
\hline \multicolumn{4}{|c|}{ a. Detected in a sample from well LWDS-MW1 collected in November 2000.} \\
\hline \multicolumn{4}{|c|}{ b. Detected in a sample from well TAV-MW7 collected in February 2002.} \\
\hline \multicolumn{4}{|c|}{ c. Detected in a sample from well LWDS-MW1 collected in September 2004.} \\
\hline \multicolumn{4}{|c|}{$\begin{array}{l}\text { d. PCE has not been detected in any TA-V monitoring well since December } 2003 \text { when it was detected at } 0.91 \mu \mathrm{g} / \mathrm{L} \text {, which is below the practical } \\
\text { quantitation limit. }\end{array}$} \\
\hline \multicolumn{4}{|c|}{ e. 40 CFR 141.61, “Maximum Contaminant Levels for Organic Contaminants.” } \\
\hline f. 40 CFR 141.62, "Maximum Conta & for Inorganic Contaminants." & & \\
\hline
\end{tabular}




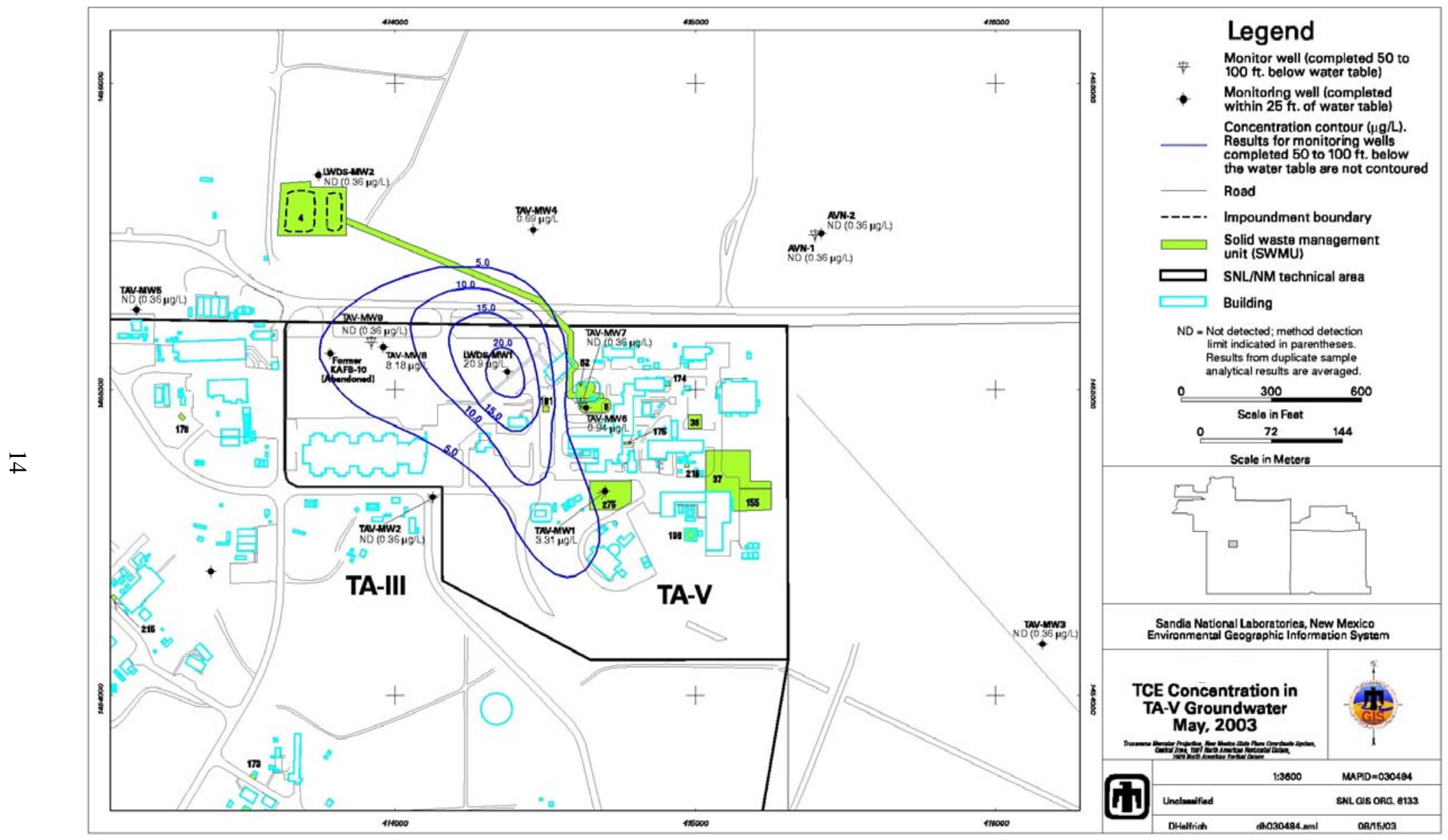

Figure 2-1. TCE concentration in TA-V groundwater (May 2003). 


\subsection{Potential Receptors}

Production wells completed in the regional aquifer of the Albuquerque Basin are the only exposure points for COCs (TCE, PCE, and nitrate) in TA-V groundwater to reach human receptors. These production wells include wells owned and operated by the City of Albuquerque (COA), KAFB, and the Veterans Administration (VA). Currently, the COC-contaminated groundwater is inaccessible to human and ecological receptors, as depth to groundwater ranges from approximately 481 to $536 \mathrm{ft}$ below ground surface (bgs) (as measured in local TA-V wells during September 2003).

Assessing the potential for migration of contaminants to current and hypothetical production wells is part of an evaluation of contaminant transport, as presented in Section 3.1.3. This evaluation took into account both existing production wells and the construction of production wells in the Mesa del Sol area. The closest existing or hypothetical production wells include:

- COA municipal well (RG-9302-S), which is approximately 6 miles downgradient of TA-V.

- KAFB production well (KAFB-4), which is approximately 3.8 miles downgradient of TA-V.

- A production well could hypothetically be installed just off of federal property 2 miles downgradient of TA-V. 


\subsection{EVALUATION OF REMEDIAL ALTERNATIVES}

This section details information gathered during the TA-V CME in order to evaluate the remedial alternatives. This work was directed by the CME Work Plan (SNL/NM 2004a) and is detailed in Section 3.1. Using these results, the remedial alternatives evaluated in this CME Report are identified and described in Section 3.2; an overview of the evaluation criteria and approach is provided in Section 3.3; the remedial alternatives evaluation is described in Section 3.4; and Section 3.5 identifies the preferred remedial alternative selected for remediation of TA-V groundwater.

\subsection{Overview of the Corrective Measures Evaluation}

An initial list of 13 technologies was identified in the CME Work Plan (SNL/NM 2004a). These 13 technologies were screened based on applicability of each technology at TA-V. Following this technology screening, four technologies remained (i.e., groundwater monitoring, monitored natural attenuation [MNA], in situ bioremediation [ISB], and pump and treat). These four technologies were used to identify nine remedial alternatives to be considered for evaluation during the CME process, as shown in Figure 3-1. The nine remedial alternatives were strategies for implementing the four technologies in order to address all COCs in TA-V groundwater.

The TA-V CME Work Plan identified four potential data gathering activities that may be performed during the CME. These activities include:

1. Paper study,

2. Numerical modeling,

3. Laboratory studies, and

4. Field scale studies.

As stated in the TA-V CME Work Plan, only activities that were determined to be necessary were performed. The utility of each data gathering activity was determined in the Remedial Alternatives Data Gaps Review, which is summarized in Section 3.1.1 and included in this CME report as Attachment B. Reports were prepared to document the results of each of the data gathering activities. A summary of each report is presented in Sections 3.1.1 through 3.1.4. The reports are included in this CME Report as Attachments B through E. Figure 3-2 illustrates the CME process and Table 3-1 lists the reports produced in support of the CME. The purpose of these reports was to:

- Report results and interpretation of results to the project leader, technical peer review panel, and technical support personnel,

- Document decisions made during the CME process and the results of the data gathering stages, and

- Provide supporting information for the CME Report. 
Technologies Identified in Section 3.0 of the CME Work Plan
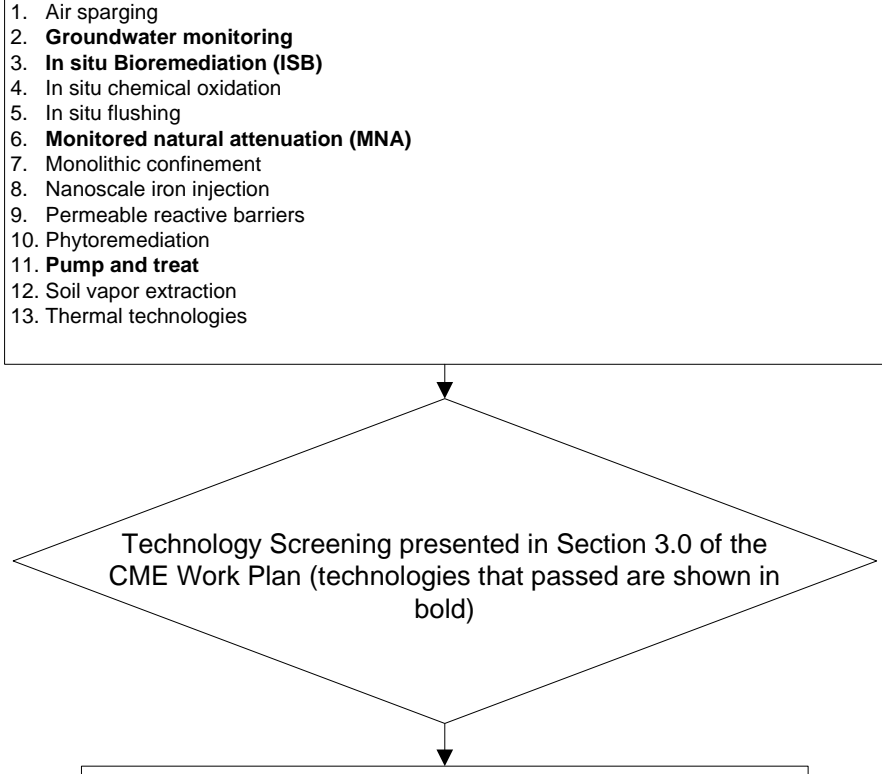

Technologies recommended for further evaluation

1. Groundwater monitoring

2. MNA

3. ISB

4. Pump and Treat

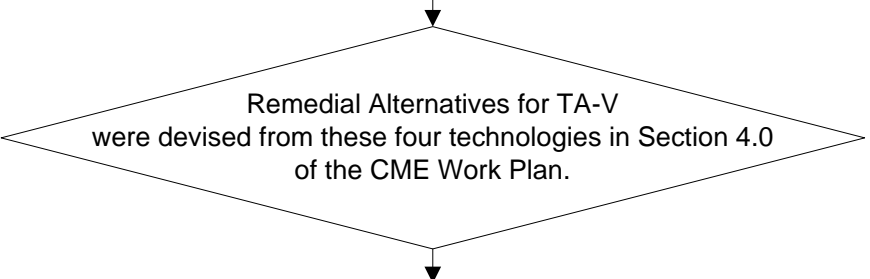

Remedial Alternatives to be Considered in CME
1. Groundwater monitoring for volatile organic compounds (VOCs) and nitrate
2. MNA for VOCs and nitrate
3. MNA for VOCS and groundwater monitoring for nitrate
4. ISB followed by MNA for VOCs and nitrate
5. ISB followed by MNA for VOCs and groundwater monitoring for nitrate
6. ISB followed by MNA for VOCS and MNA for nitrate
7. Pump-and-treat followed by MNA for VOCs and nitrate
8. Pump-and-treat followed by MNA for VOCs and groundwater monitoring for nitrate
9. Pump-and-treat followed by MNA for VOCs and MNA for nitrate

Figure 3-1. Illustration of the process of devising remedial alternatives. 


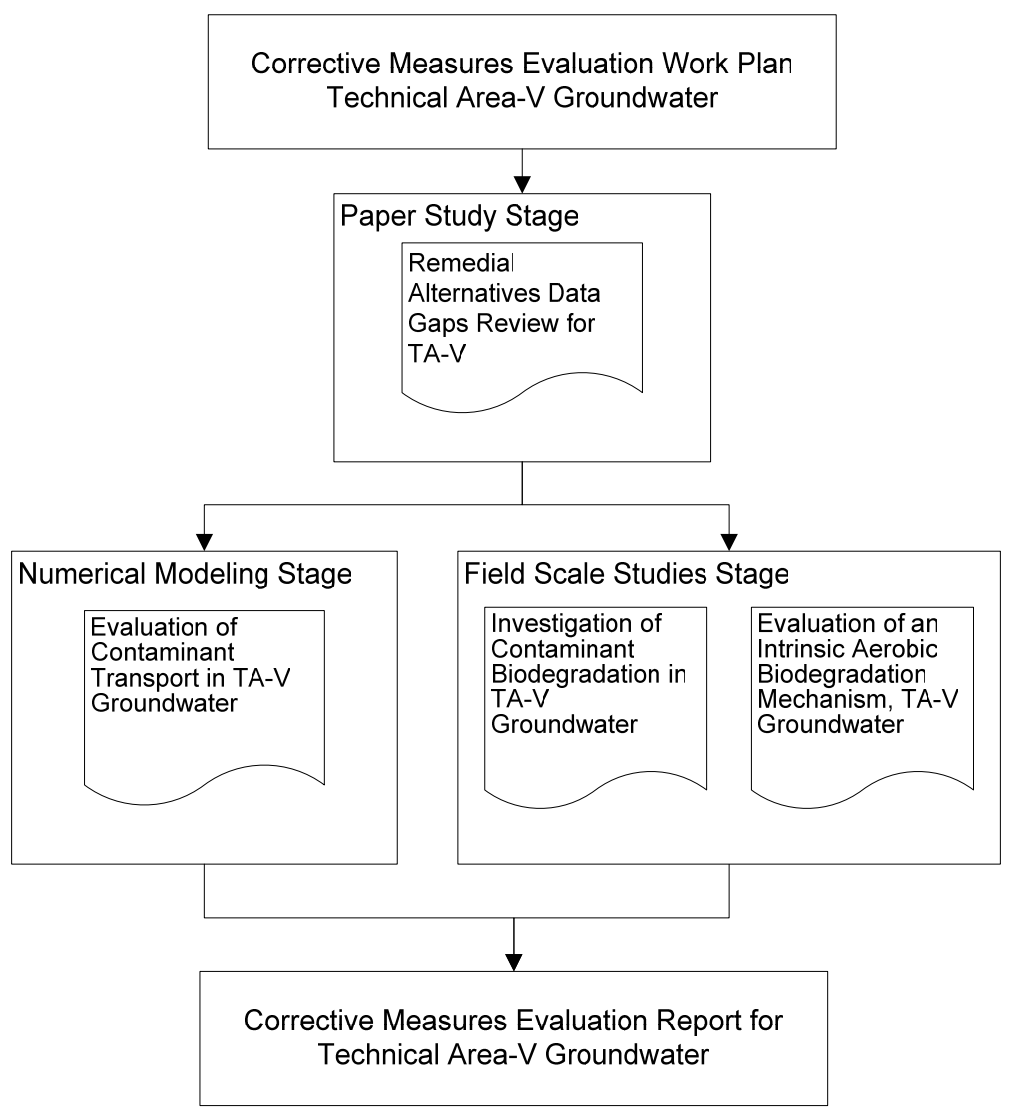

Figure 3-2. Illustration of the staged process of data gathering activities and production of informal reports.

Table 3-1. Outline of documents produced in support of the Corrective Measures Evaluation.

\begin{tabular}{|c|c|c|}
\hline $\begin{array}{l}\text { Section in } \\
\text { CME Report }\end{array}$ & Document Title & Attachment \\
\hline Section 3.1.1 & $\begin{array}{l}\text { Remedial Alternatives Data Gaps Review } \\
\text { (Paper Study Stage) }\end{array}$ & Attachment B \\
\hline Section 3.1.2 & $\begin{array}{l}\text { Evaluation of Contaminant Transport in Groundwater } \\
\text { (Numerical Modeling Stage) }\end{array}$ & Attachment C \\
\hline Section 3.1.3 & $\begin{array}{l}\text { Investigation of Intrinsic Anaerobic Biodegradation } \\
\text { (Field Scale Studies Stage) }\end{array}$ & Attachment D \\
\hline Section 3.1.4 & $\begin{array}{l}\text { Evaluation of an Intrinsic Aerobic Biodegradation } \\
\text { Mechanism (Field Scale Studies Stage) }\end{array}$ & Attachment E \\
\hline
\end{tabular}




\subsubsection{Remedial Alternatives Data Gaps Review}

The Remedial Alternatives Data Gaps Review (Attachment B) documents the results of the paper study. The Remedial Alternatives Data Gaps Review presents conceptual designs for each remedial alternative, which include an overview of the remedial alternative, a description of the technical and functional requirements (T\&FRs), and a list of the expected costs for each remedial alternative.

A preliminary remedial alternative evaluation was performed based on information gathered during the paper study stage, which was the first stage of the CME process. Therefore, this preliminary remedial alternative evaluation was intended to be updated upon completion of subsequent CME stages. The final remedial alternative evaluation is presented in Section 3.4. Completion of this Remedial Alternatives Data Gaps Review produced the following two conclusions:

1. Of the initial list of nine remedial alternatives stated in the CME Work Plan (SNL/NM 2004a), four remedial alternatives were recommended for continued evaluation during the remainder of the CME (Figure 3-3), and

2. Data gathering activities for the four remaining alternatives were recommended for two of the CME stages (numerical modeling and field scale studies). Several of the data gathering activities, discussed as possibilities in the CME Work Plan, were determined to be unnecessary.

Based on the information gathered, assessed, and summarized in the Remedial Alternatives Data Gaps Review, recommendations were made regarding the need of performing activities to evaluate the four remaining remedial alternatives during the final three CME stages, as follows:

- Numerical modeling was recommended, as planned in the TA-V CME Work Plan;

- Field scale studies were recommended:

- to investigate anaerobic mechanisms of biodegradation during natural attenuation,

- to investigate aerobic TCE biodegradation mechanisms during natural attenuation, as planned in the TA-V CME Work Plan.

The following studies were not recommended:

- Laboratory studies;

- Field-scale studies for ISB; and

- Field-scale studies for pump and treat. 


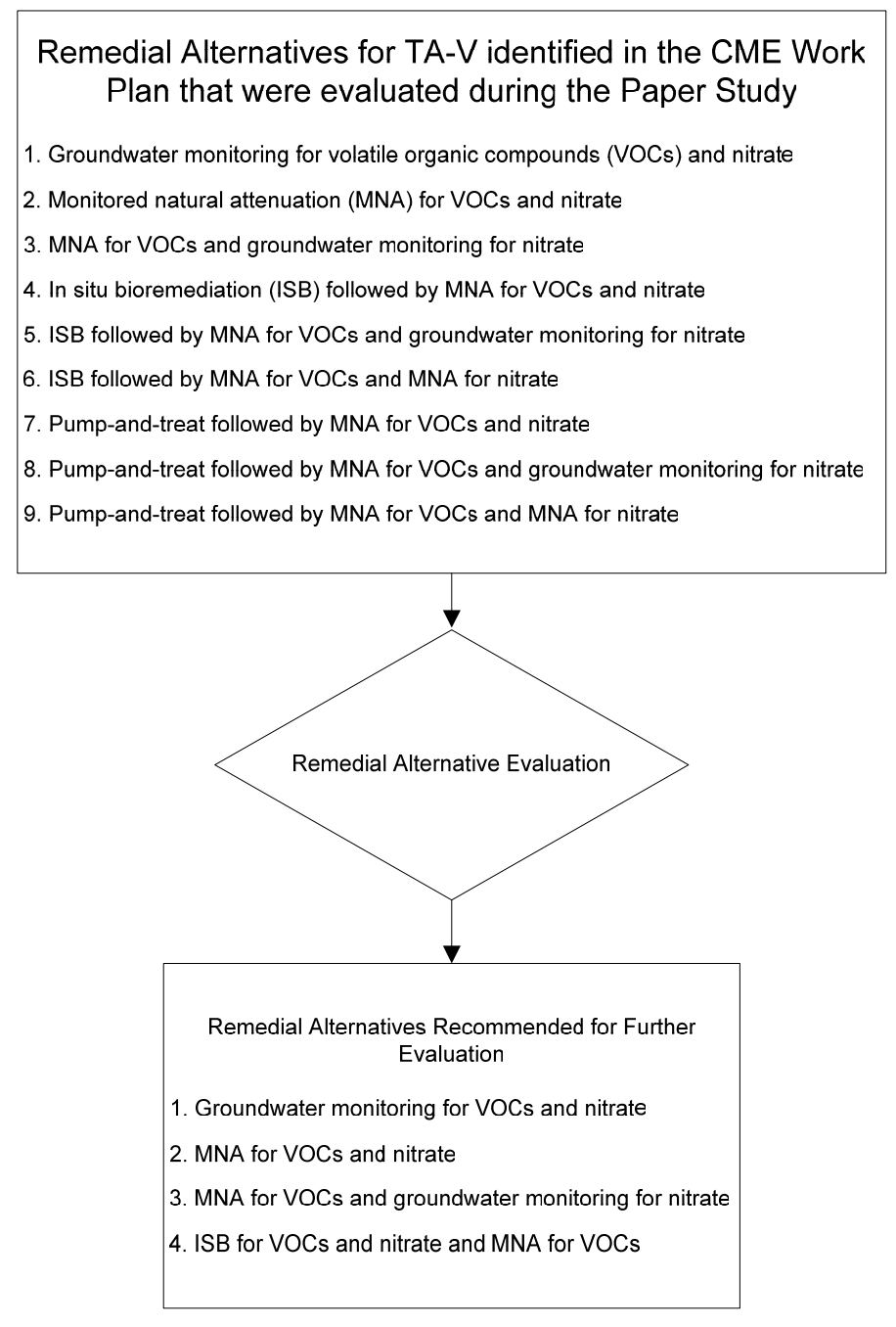

Figure 3-3. Changes in remedial alternatives for TA-V groundwater during the Paper Study.

\subsubsection{Evaluation of Contaminant Transport in Groundwater}

As part of the CME, a numerical modeling study was performed to evaluate the potential for COC migration to receptors (production wells) and concentration reduction during transport. The complete Evaluation of Contaminant Transport in Groundwater report is included as Attachment C. This evaluation was performed using a cross-sectional modeling approach to evaluate transport and concentration reduction along a flow path between the current location of contaminants and production wells. 
The study incorporated two cross-sectional models to simulate concentrations relative to an initial unit concentration (1 unit or 100\%) in groundwater at TA-V. The first model represented westward groundwater flow in the alluvial fan lithofacies beneath TA-V. The second model represented northward flow within the ARG toward COA and KAFB production wells. In order to evaluate concentration reduction conservatively, the cross-sectional models intentionally neglected contaminant biodegradation, sorption, and lateral dispersion.

The results indicated that significant attenuation of contaminants would occur due to dilution by underflow that enters the aquifer along the flowpath to the production wells. The simulation indicated that contaminant concentrations would be diluted by approximately four orders of magnitude before reaching potential pumping wells in the ARG lithofacies. The minimum travel time of groundwater and conservative solutes from TA-V to the Ridgecrest well field was estimated to be 230 years; however, before the end of this timeframe, contaminant concentrations will be below MCLs. When compared to the maximum historical concentrations presented in Section 2.1, these results demonstrate that the natural attenuation mechanism of dilution will reduce the concentration of all three COCs to below their respective MCLs before reaching the production wells.

\subsubsection{Investigation of Intrinsic Anaerobic Biodegradation}

An investigation of anaerobic contaminant biodegradation was performed as part of the CME to evaluate MNA. The complete Investigation of Contaminant Biodegradation report is included as Attachment D. This evaluation was performed using the volatile organic compound (VOC) contaminant biodegradation screening assessment described in the Technical Protocol for Evaluating Natural Attenuation of Chlorinated Solvents in Ground Water (EPA 1998) and a biodegradation evaluation for nitrate.

The evaluation used sample data collected during the first- (November 17 to December 4, 2003) and second- (March 29 to April 16, 2004) quarter sampling rounds of FY 2004. For each parameter, the significance of the data relative to assessing biodegradation and general observations was evaluated. The results indicated that biodegradation via the process of anaerobic reductive dechlorination (ARD) is not occurring in TA-V groundwater. In addition, anaerobic biodegradation of nitrate via denitrification is not occurring in the TA-V groundwater.

\subsubsection{Evaluation of an Intrinsic Aerobic Biodegradation Mechanism}

As part of the CME, a field scale study was performed to investigate the natural attenuation mechanism of aerobic biodegradation via aerobic cometabolic oxidation. The complete Evaluation of Intrinsic Aerobic Biodegradation report is included as Attachment E. This field study coupled enzyme activity probes (evidence of cometabolic enzyme activity) with deoxyribonucleic acid (DNA) analysis (evidence of cometabolic gene presence) to evaluate cometabolic activity, or the potential for such activity, at TA-V.

Enzyme activity probes provide direct evidence that the mechanism for aerobic cometabolic oxidation of chlorinated ethenes is present and active in a given sample. Organisms that oxidize substrates such as toluene or methane also oxidize TCE. Thus, cometabolism of TCE will occur if the appropriate enzymes are both present and active. Probes that serve as alternate substrates for TCE-cometabolizing enzymes have been developed for several of the toluene oxygenases and 
for the soluble methane monooxygenase (sMMO). These non-fluorescent probes are transformed by oxygenase enzymes into strongly fluorescent products, providing a clear, quantifiable signal only when the enzyme of interest is actively functioning. In addition to the enzyme probes, DNA analysis was performed to investigate the genetic potential of toluene and methane-oxidizing microbial populations. This technique is designed to look for the presence of the toluene or methane oxygenase gene.

The application of enzyme activity probes to groundwater samples demonstrated that toluene oxygenase and sMMO enzymes were present and active in all of the wells at TA-V. All 13 of the wells sampled at the TA-V site had a positive response with the sMMO enzyme activity probe and at least one of the toluene probes. DNA results for the sMMO gene showed that groundwater samples from all of the wells were positive for the presence of the sMMO gene. A positive response (active enzymes) was found both inside and outside the contaminated area at TA-V, for both the sMMO and toluene oxygenase enzyme probes. These data provide conclusive evidence of active enzyme systems capable of TCE biodegradation at TA-V, and more importantly represent an active mechanism for the natural attenuation of contaminants.

\subsection{Identification and Description of Remedial Alternatives}

Four remedial alternatives were evaluated in order to select a preferred remedial alternative for TA-V groundwater. These four alternatives include:

1. Groundwater monitoring for VOCs and Nitrate;

2. MNA for VOCs and Nitrate;

3. MNA for VOCs and Groundwater Monitoring for Nitrate; and

4. ISB for VOCs and Nitrate and MNA for VOCs.

During the CME process, evaluation of contaminant transport (Section 3.1.2) and determination of the presence of an aerobic biodegradation mechanism (Section 3.1.4) identified that natural attenuation mechanisms are present for all COCs in TA-V groundwater. Evidence of these natural attenuation mechanisms no longer allows for an accurate comparison of groundwater monitoring and MNA as separate remedial alternatives; therefore, remedial alternatives containing groundwater monitoring (i.e., groundwater monitoring for VOCs and Nitrate, and MNA for VOCs and Groundwater Monitoring for Nitrate) are no longer being considered. Evaluation of the following two remedial alternatives was performed:

1. MNA for VOCs and Nitrate; and

2. ISB for VOCs and Nitrate and MNA for VOCs.

A description of each remedial alternative, as defined during the CME process, is provided in the following sections. Descriptions include T\&FRs and cost elements. 


\subsubsection{MNA for VOCs and Nitrate}

Implementation of MNA for VOCs and Nitrate requires consideration of site conditions, including identifying natural attenuation mechanisms and potential receptors. MNA is not a default or presumptive remedial alternative but rather is an acceptable remedial alternative to be evaluated with other alternatives (EPA 1999). The EPA has provided policy and guidance on the use of MNA as a remedy in the Use of MNA at Superfund, RCRA Corrective Action, and Underground Storage Tank Sites (EPA 1999). The DOE used principles set forth in EPA's directive as a foundation for a decision making framework for evaluating the effectiveness of MNA. This framework is set forth in the Decision-Making Framework Guide for the Evaluation and Selection of Monitored Natural Attenuation Remedies at Department of Energy Sites (DOE 1999). This decision making framework was used when considering the MNA for VOCs and Nitrate remedial alternative during the CME. Figure 3-4 is an illustration of DOE's tiered approach to evaluating MNA.

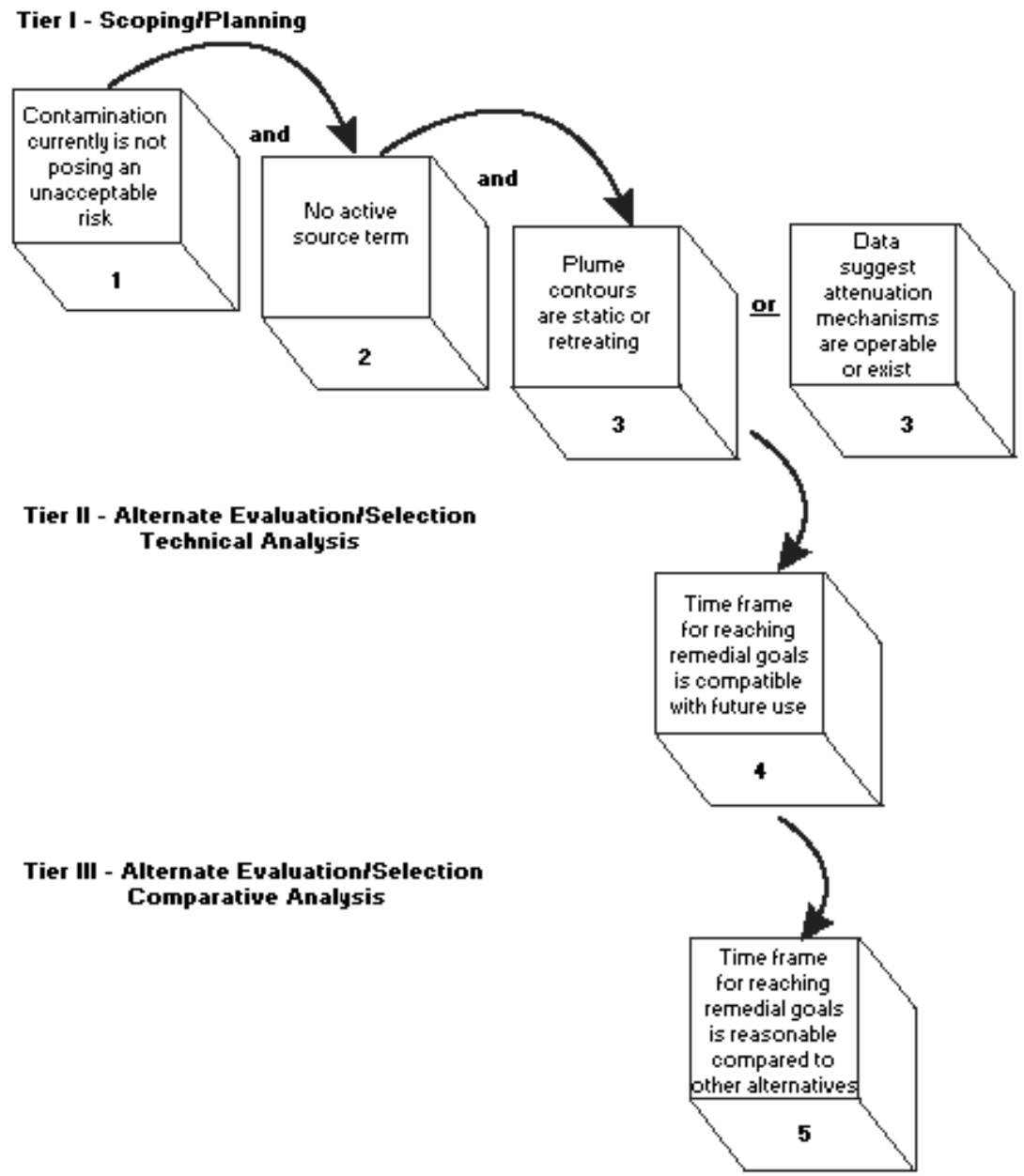

Figure 3-4. Decision framework for evaluating MNA (from DOE 1999). 
MNA for VOCs and Nitrate has been found to be an appropriate and applicable remedial alternative for TA-V groundwater. A summary of determinations made concerning each of the tiers of the DOE decision making framework is as follows:

1. Tier I. Item 1. Contamination currently is not posing an unacceptable risk. The contaminated groundwater is currently inaccessible to potential receptors, as depth to groundwater ranges from approximately 481 to $536 \mathrm{ft}$ bgs (as measured in local TA-V wells during September 2003), and there are no nearby production wells. In addition, the Evaluation of Contaminant Transport in Groundwater (see Section 3.1.2 and Attachment C) has demonstrated that contaminants do not pose an unacceptable risk to potential receptors at production wells in the future.

2. Tier I. Item 2. There is no active source term. Source control technologies are to be used to control an active source term, which has been defined as a source inventory of contaminant that is being released to the groundwater where the rate of contaminant release is greater than attenuation rates such that the inventory of mobile contaminants is increasing over time (DOE 1999). One important conclusion of the TA-V Current Conceptual Model is that there is no ongoing source; therefore, source control measures will not be a necessary component of a remedy at TA-V (SNL/NM 2004b).

3. Tier I. Item 3. Plume contours are static (or are retreating) or data suggests that attenuation mechanisms are operable (or exist). COC concentration data presented in the NMED approved Current Conceptual Model (SNL/NM 2004b) and updated in Attachment A of this report show that COC concentrations are not increasing as monitored in the TA-V monitoring well network, demonstrating that the plume contours are stable. In addition, natural attenuation mechanisms have been demonstrated. Natural attenuation processes or mechanisms may include biodegradation, dispersion, dilution, sorption, volatilization, stabilization, transformation, or destruction of contaminants (EPA 1999). The approach used during the CME process to evaluate MNA was to focus on investigating two of these natural attenuation mechanisms, dilution and biodegradation. Although other natural attenuation mechanisms may be operable, further reducing contaminant concentrations, they were not evaluated. Evaluation of dilution during transport (see Section 3.1.2 and Attachment C) has demonstrated that this mechanism will reduce COC concentrations to orders of magnitude below MCLs. Evaluation of biodegradation mechanisms (see Section 3.1.4 and Attachment E) has demonstrated that a mechanism for aerobic biodegradation of TCE exists.

4. Tier II. Item 4. Timeframe for reaching remedial goals is compatible with future use. There is no current use of TA-V groundwater within the TA-V boundary. However, in the future as this groundwater migrates west and north off of the federal property, it may be extracted from the aquifer for potable water. The Transport Evaluation (see Section 3.1.2 and Attachment C) demonstrates that contaminants will be reduced by several orders of magnitude before reaching these production wells and will be below the federal drinking water standards (MCLs). This analysis intentionally neglected other potential attenuation mechanisms that could further reduce contaminant concentrations. 


\section{Tier III. Item 5. Timeframe for reaching remedial goals is reasonable compared to}

other alternatives. Evaluation of the remedial timeframe compared to other alternatives is part of the criteria used to evaluate remedial alternatives and is discussed in Section 3.4.

Given these criteria and site-specific information, MNA for VOCs and Nitrate is a viable remedial alternative for TA-V groundwater and is considered in the Remedial Alternative Evaluation presented in Section 3.4. The T\&FRs that define the MNA for VOCs and Nitrate remedial alternative are presented in Table 3-2. Assumptions of these T\&FRs include the ability to monitor for the appropriate remedial timeframe, which would require maintaining the necessary equipment, utilities, personnel availability, and a sufficient monitoring well network. Cost elements to be considered for implementing MNA for VOCs and Nitrate are outlined in Table 3-3 and include capital equipment and operations and maintenance cost items, as defined in Section 3.3.2.

Table 3-2. T\&FRs for MNA for VOCs and Nitrate.

\begin{tabular}{l|l}
\hline \multicolumn{1}{c|}{ Parameter } & \multicolumn{1}{c}{ Requirement } \\
\hline Duration of monitoring & $\begin{array}{l}\text { Groundwater monitoring would continue until it is demonstrated } \\
\text { that contaminants are below MCLs for a period of time that will be } \\
\text { determined during preparation of the CMI Plan. }\end{array}$ \\
\hline Frequency of monitoring & Annual. \\
\hline Analytes & $\begin{array}{l}\text { All COCs (PCE, TCE, and nitrate), water levels, and parameters to } \\
\text { monitor attenuation mechanisms. }\end{array}$ \\
\hline Reporting & $\begin{array}{l}\text { The monitoring data would be analyzed and interpreted. This data } \\
\text { would be used to monitor attenuation mechanisms and track COC } \\
\text { concentration changes. }\end{array}$ \\
\hline $\begin{array}{l}\text { Replacement monitoring } \\
\text { wells }\end{array}$ & $\begin{array}{l}\text { Annual reporting for the first 5 years, followed by reporting every } \\
5 \text { years until the end of long-term operations. Reports would } \\
\text { include analysis of concentration trends and comparison to } \\
\text { predicted trends of attenuation, which will be in the CMI Plan. }\end{array}$ \\
\hline Equipment & $\begin{array}{l}\text { A monitoring well network would be maintained throughout the } \\
\text { to regional water level decline or other factors. }\end{array}$ \\
\hline Equipment storage & $\begin{array}{l}\text { All equipment necessary for monitoring including pumps, sample } \\
\text { bottles, power (generator or utilities), shipping supplies, purge } \\
\text { water tanks, personal protection equipment, and any other } \\
\text { necessary equipment. }\end{array}$ \\
\hline
\end{tabular}


Table 3-2. (continued).

\begin{tabular}{l|l}
\hline \multicolumn{1}{c|}{ Parameter } & \multicolumn{1}{c}{ Requirement } \\
\hline Waste storage & Storage of purge water until authorized to dispose. \\
\hline $\begin{array}{l}\text { Institutional } \\
\text { controls }\end{array}$ & $\begin{array}{l}\text { Institutional controls consist of engineering and administrative controls } \\
\text { to protect current and future users from health risks associated with } \\
\text { exposure to contaminated groundwater. Engineering controls consist of } \\
\text { methods to restrict access to contaminated water, including locking } \\
\text { devices on wellheads. Administrative controls include postings on } \\
\text { wellheads identifying potential hazards and placing written notification } \\
\text { of this corrective measure in the facility land-use master plan. }\end{array}$ \\
\hline Operations & $\begin{array}{l}\text { Operations consist of groundwater monitoring and maintenance } \\
\text { associated with institutional controls. }\end{array}$ \\
\hline Facilities & No additional facilities are required. \\
\hline
\end{tabular}

Table 3-3. Itemized costs for the MNA for VOCs and Nitrate remedial alternative.

\begin{tabular}{l|l}
\hline \multicolumn{1}{c|}{ Capital } & \multicolumn{1}{c}{ Operations and Maintenance } \\
\hline $\begin{array}{l}\text { - } \begin{array}{l}\text { Costs associated with designing } \\
\text { a long-term groundwater } \\
\text { monitoring program. }\end{array} \\
\begin{array}{l}\text { - Costs of characterizing natural } \\
\text { attenuation. }\end{array}\end{array}$ & $\begin{array}{l}\text { - } \begin{array}{l}\text { Costs of maintaining an adequate monitoring well } \\
\text { network for the duration of the remedy while } \\
\text { regional water levels decline. }\end{array} \\
\text { - Indirect costs (legal and } \\
\text { permitting fees). }\end{array}$ \\
$\begin{array}{l}\text { - Sampling and analyses costs. } \\
\text { - Reporting costs for the duration of the remedy. }\end{array}$ \\
$\begin{array}{l}\text { - Indirect operational costs, including institutional } \\
\text { controls, contingency allowances, and administrative } \\
\text { costs. }\end{array}$ \\
\hline
\end{tabular}

\subsubsection{ISB for VOCs and Nitrate and MNA for VOCs}

Application of this remedial alternative at TA-V would begin by implementing ISB for VOCs and Nitrate. ISB implementation would target the aquifer region with higher TCE

concentrations. The highest nitrate concentrations are located in this same area and would also be reduced via denitrification when amendments are injected. MNA will be implemented for the lower concentration zones and for the entire contaminated area following completion of ISB to further reduce contaminant concentrations and ensure that clean up goals are met for the entire plume. Therefore, the requirements and costs associated with both ISB and MNA are necessary components of this remedial alternative. 
Implementation of ISB would require injecting amendments to induce biological activity, which will change aquifer conditions from aerobic to anaerobic and induce anaerobic processes of biodegradation. Amendments will only be distributed to the high concentration zone of the plume. This system would be composed of at least one amendment injection well and would include an amendment injection facility.

The most significant technical challenge of implementing ISB is distribution of amendments to contaminated portions of the aquifer. Scoping calculations, presented in Attachment B, demonstrate that distribution of amendments to the higher concentration zones using several injection wells is only feasible under the most favorable conditions. However, the calculations also demonstrate that distribution of amendments may not be feasible under less favorable conditions.

As stated in the CME Work Plan, data gathering activities were carried out in a staged approach. It was decided during the paper study stage that conducting an injection test would be postponed until after an evaluation of remedial alternatives was performed. ISB implementation (given the most favorable conditions) was considered in the evaluation presented in this report. If the ISB for VOCs and Nitrate and MNA for VOCs remedial alternative is determined to be the preferred remedial alternative under the most favorable conditions, then it would be appropriate to investigate if those conditions exist using an injection demonstration.

Table 3-4 lists the T\&FRs for this remedial alternative. This remedial alternative was evaluated based on the following assumptions:

- Necessary equipment, utilities, personnel, and a sufficient injection and monitoring well network will be made available.

- A dechlorinating microbial community can be induced by the injection of amendments.

- Favorable conditions for amendment distribution exist (details in Attachment B). A conservative estimate, presented in the Data Gaps Review (Attachment B), demonstrates that sufficient distribution of amendments is only feasible given the most favorable observed conditions.

Table 3-4. T\&FRs for ISB for VOCs and Nitrate and MNA for VOCs.

\begin{tabular}{l|l}
\hline \multicolumn{1}{c|}{ Parameter } & \multicolumn{1}{c}{ Requirement } \\
\hline $\begin{array}{l}\text { Duration of } \\
\text { monitoring }\end{array}$ & $\begin{array}{l}\text { Monitoring of groundwater would increase in frequency in all wells } \\
\text { during, and for a short period of time after, the amendment } \\
\text { injection(s). It is estimated that monitoring would continue at a } \\
\text { reduced frequency for several years after the beginning of remedy } \\
\text { implementation. }\end{array}$ \\
\hline $\begin{array}{l}\text { Frequency of } \\
\text { monitoring }\end{array}$ & $\begin{array}{l}\text { ISB monitoring would include sampling and analyses, in addition to } \\
\text { MNA monitoring, necessary to monitor the effect of amendment } \\
\text { injections. A period of groundwater monitoring following ISB } \\
\text { injections would be required to confirm clean up goals are achieved. }\end{array}$ \\
\hline
\end{tabular}


Table 3-4. (continued).

\begin{tabular}{|c|c|}
\hline Parameter & Requirement \\
\hline Analytes & $\begin{array}{l}\text { All COCs (PCE, TCE, and nitrate), water levels, parameters necessary } \\
\text { to monitor ISB operations (i.e., chemical oxygen demand to monitor } \\
\text { amendment distribution and utilization), and parameters necessary to } \\
\text { monitor attenuation mechanisms. }\end{array}$ \\
\hline Analyses & $\begin{array}{l}\text { The groundwater monitoring data would be analyzed and interpreted. } \\
\text { Data would be used to track the performance of ISB and monitor } \\
\text { contaminant reduction. }\end{array}$ \\
\hline Reporting & $\begin{array}{l}\text { Annual reporting for first } 5 \text { years, followed by annual data summaries } \\
\text { with formal reports submitted every } 5 \text { years until the end of long-term } \\
\text { operations. Reports would include analysis of concentration trends and } \\
\text { comparison to predicted trends of attenuation. }\end{array}$ \\
\hline $\begin{array}{l}\text { Sampling } \\
\text { equipment }\end{array}$ & $\begin{array}{l}\text { All equipment necessary for monitoring, including pumps, sample } \\
\text { bottles, power (generator or utilities), shipping supplies, purge water } \\
\text { tanks, personal protection equipment, and any other necessary } \\
\text { equipment. }\end{array}$ \\
\hline Equipment storage & $\begin{array}{l}\text { Storage for amendments, injection system, field sampling equipment, } \\
\text { and waste. }\end{array}$ \\
\hline Waste storage & Storage of purge water and drill cuttings until authorized to dispose. \\
\hline $\begin{array}{l}\text { Institutional } \\
\text { controls }\end{array}$ & $\begin{array}{l}\text { Institutional controls consist of engineering and administrative controls } \\
\text { to protect current and future users from health risks associated with } \\
\text { exposure to contaminated groundwater. Engineering controls consist of } \\
\text { methods to restrict access to contaminated water, including locking } \\
\text { devices on wellheads. Administrative controls include postings on } \\
\text { wellheads identifying potential hazards and placing written notification } \\
\text { of this corrective measure in the facility land-use master plan. }\end{array}$ \\
\hline \multirow{2}{*}{ Operations } & $\begin{array}{l}\text { Duration of ISB operations would be determined prior to } \\
\text { implementation. It is estimated that ISB would require a relatively short } \\
\text { implementation period followed by confirmatory monitoring. The } \\
\text { implementation would require less time than the other remedies. }\end{array}$ \\
\hline & $\begin{array}{l}\text { An injection event would require several days of continuous injection } \\
\text { into one or two wells. This estimate is only valid assuming the well(s) } \\
\text { will accept the injection at a sufficient rate and distribution is } \\
\text { approximately radial. }\end{array}$ \\
\hline Facilities & $\begin{array}{l}\text { The injection facility would be capable of mixing amendments into } \\
\text { potable water and injecting at a maximum of } 5 \text { gpm. The facility may } \\
\text { be temporary. At least one injection well would need to be constructed. }\end{array}$ \\
\hline
\end{tabular}


Cost elements to be considered for implementing ISB for VOCs and Nitrate and MNA for VOCs are outlined in Table 3-5 and include capital equipment and operations and maintenance costs, as defined in Section 3.3.2.

Table 3-5. Itemized costs for the ISB and MNA for VOCs and ISB for Nitrate remedial alternative.

\begin{tabular}{|c|c|}
\hline Capital & Operations and Maintenance \\
\hline $\begin{array}{l}\text { - } \text { Engineering costs to design ISB system. } \\
\text { - Costs associated with designing a long- } \\
\text { - } \text { Costs groundwater monitoring program. } \\
\text { attenuation. } \\
\text { - Construction of injection well(s). } \\
\text { - Construction of an injection facility. } \\
\text { - } \text { Indirect costs (legal and permitting fees). }\end{array}$ & $\begin{array}{l}\text { - Includes labor, material, and equipment costs } \\
\text { to inject continuously for several days. } \\
\text { - Cost of amendments. } \\
\text { - Sampling and analyses costs for both ISB } \\
\text { and MNA components of the remedy. } \\
\text { - Reporting costs for the duration of the } \\
\text { remedy. } \\
\text { - Costs for data analyses and interpretation. } \\
\text { - Costs of maintaining an adequate monitoring } \\
\text { well network for the duration of the ISB and } \\
\text { MNA components of the remedy. } \\
\text { - Indirect operational costs, including } \\
\text { institutional controls, contingency } \\
\text { allowances, and administrative costs. }\end{array}$ \\
\hline
\end{tabular}

\subsection{Overview of Evaluation Criteria and Approach}

Each remedial alternative was evaluated using the threshold and remedial alternative criteria, as stated in the TA-V CME Work Plan (SNL/NM 2004a) and specified in the COOC

(Section VII.C.3, CME Criteria [NMED 2004]). The purpose of the evaluation criteria is to provide a basis for comparing the remedial alternatives. This section provides details for both the threshold and remedial alternative evaluation criteria.

\subsubsection{Threshold Criteria}

Each remedial alternative will be evaluated to assure that it can meet the threshold criteria. The following threshold criteria were evaluated:

- Protective of human health and the environment. Any proposed remedy must be protective of human health and the environment. As stated in the Resource Conservation and Recovery Act (RCRA) Corrective Action Plan, "Remedies may include those measures that are needed to be protective but are not directly related to media cleanup, source control, or management of wastes" (EPA 1994). Components of remedies considered at TA-V include evaluating protection of human health and the environment for air emissions, potential formation of hazardous degradation products, any hazards associated with operations and maintenance of the remedy, and remediation within an appropriate timeframe. 
- Attain media cleanup standard or alternative, approved risk-based cleanup goals. Any proposed remedy must attain groundwater cleanup standards or goals. As stated in the RCRA Corrective Action Plan, "Remedies will be required to attain media cleanup standards set by the implementing agency, which may be derived from existing state or federal regulations (e.g., groundwater standards) or other standards. The media cleanup standards for a remedy will often play a large role in determining the extent of, and technical approaches to, the remedy" (EPA 1994). The cleanup goals and objectives for $\mathrm{TA}-\mathrm{V}$ are described in Section 4.1. If a remedy cannot meet any one of these goals or objectives, it should no longer be considered.

- Comply with standards for management of wastes. Any proposed remedy must comply with all applicable state or federal regulations. As stated in the RCRA Corrective Action Plan, "Waste management activities will be conducted in compliance with all applicable state or federal regulations (e.g., closure requirements, land disposal restrictions)" (EPA 1994). In addition, waste is to be managed according to the requirements of SNL/NM's Environment, Safety, and Health (ES\&H) Manual, "Chapter 19 - Waste Management," which describes the main institutional requirements relevant to waste management on SNL/NM-controlled premises (SNL/NM 2005b). For remedies considered at TA-V, waste could be generated during the life cycle of the remedy in the form of contaminated groundwater brought to the surface and laboratory and field sampling wastes, and at the completion of the remedy during final decommissioning of the remedy system.

As discussed in the TA-V Current Conceptual Model (SNL/NM 2004b), there is no ongoing source of contaminants; therefore, the source control threshold criterion will not be evaluated. The TA-V CME Work Plan (SNL/NM 2004a) identifies that the threshold criteria will be evaluated qualitatively, so a YES/NO evaluation will be used. If a remedial alternative does not meet a threshold criterion (i.e., it received a NO evaluation), the remedial alternative will be eliminated.

\subsubsection{Remedial Alternative Criteria}

Remedial alternative evaluation criteria will be evaluated for each remedy. As specified in the COOC (NMED 2004), the remedial alternative evaluation must be balanced and includes the following:

- Long-term reliability and effectiveness. In general, this criterion evaluates the reliability of the remedy for meeting cleanup standards and reducing risk. As stated in the COOC, "Each remedy shall be evaluated for long-term reliability and effectiveness. This factor includes consideration of the magnitude of the risks that will remain after implementation of the remedy; the extent of long-term monitoring or other management that will be required after implementation of the remedy; the uncertainties associated with leaving contaminants in place; and the potential for failure of the remedy. A remedy that reduces risks with little long-term management, and that has proven effective under similar conditions, shall be preferred" (NMED 2004). This criterion will include defining the institutional controls to be established at TA-V for each remedy. 
- Reduction of toxicity, mobility, or volume. This criterion is intended to evaluate the effectiveness of the remedy for reducing TCE, PCE, and nitrate concentrations in the TA-V groundwater plume. As stated in the COOC, "Each remedy shall be evaluated for its reduction in the toxicity, mobility, and volume of contaminants. A remedy that more completely and permanently reduces the toxicity, mobility, and volume of contaminants shall be preferred" (NMED 2004).

- Short-term effectiveness. In general, short-term effectiveness applies to the ability of the remedy to reduce risks during the remediation process. These risks include exposure to contaminants during remedy implementation and risks and hazards introduced by remedy implementation. As stated in the COOC, "Each remedy shall be evaluated for its short-term effectiveness. This factor includes consideration of the short-term reduction in existing risks that the remedy would achieve; the time needed to achieve that reduction; and the short-term risks that might be posed to the community, workers, and the environment during implementation of the remedy. A remedy that quickly reduces shortterm risks, without creating significant additional risks, shall be preferred” (NMED 2004).

- Feasibility. As stated in the COOC, "Each remedy shall be evaluated for its feasibility or the difficulty of implementing the remedy. This factor includes consideration of installation and construction difficulties; operation and maintenance difficulties; difficulties with cleanup technology; permitting and approvals; and the availability of necessary equipment, services, expertise, and storage and disposal capacity. A remedy that can be implemented quickly and easily and poses fewer and lesser difficulties shall be preferred" (NMED 2004).

- Cost. As stated in the COOC, "Each remedy shall be evaluated for its cost." This factor includes a consideration of both capital costs and operation and maintenance costs. "A remedy that is less costly, but does not sacrifice protection of health and the environment, shall be preferred" (NMED 2004).

- Capital costs shall include, without limitation, construction and installation costs; equipment costs; land development costs; and indirect costs, including engineering costs, legal fees, permitting fees, startup and shakedown costs, and contingency allowances.

- Operation and maintenance costs shall include, without limitation, operating labor and materials costs; maintenance labor and materials costs; replacement costs; utilities; monitoring and reporting costs; administrative costs; indirect costs; and contingency allowances” (NMED 2004).

The TA-V CME Work Plan identifies that the threshold criteria will be evaluated quantitatively by assigning numerical values. The comparative analysis for each remedial alternative using the remedial alternative criteria will be performed using the following ratings:

$\begin{array}{lll}“+” & = & \text { Meets the remedial alternative criterion, } \\ { }^{\prime++}, & = & \text { Effectively meets the remedial alternative criterion, and } \\ { }_{+}++ & = & \text {More effectively meets the remedial alternative criterion. }\end{array}$


The total number of pluses represents how effectively the remedial alternative meets the criterion. Therefore, with six categories, the possible numerical scores range from 6 to 18. This approach balances the criteria in order to evaluate each remedial alternative in a simple, comparative manner.

\subsection{Remedial Alternatives Evaluation}

The two remaining remedial alternatives are evaluated using the threshold and the remedial alternative criteria described in Section 3.3. The results of the threshold evaluation are presented in Table 3-6. As demonstrated, both of the remedial alternatives meet the threshold criteria and received a YES rating for each of the three categories.

Since both remedial alternatives met the threshold criteria, both remedial alternatives were evaluated using the remedial alternative criteria. The results of this quantitative evaluation are presented in Table 3-7 and detailed information supporting the ratings is presented in Table 3-8. The supporting information states advantages and disadvantages for each remedial alternative to provide rationale for the quantitative analyses ratings assigned for each criterion.

Table 3-6. Qualitative threshold criteria evaluation.

\begin{tabular}{l|c|c|c}
\hline \multicolumn{1}{|c|}{ Remedial Alternatives } & $\begin{array}{c}\text { Protective of } \\
\text { Human Health } \\
\text { and } \\
\text { Environment }\end{array}$ & $\begin{array}{c}\text { Attain Media } \\
\text { Cleanup } \\
\text { Standards }\end{array}$ & $\begin{array}{c}\text { Waste } \\
\text { Management } \\
\text { Standards } \\
\text { Compliance }\end{array}$ \\
\hline MNA for VOCs and Nitrate & YES & YES & YES \\
ISB for VOCs and Nitrate and MNA for VOCs & YES & YES & YES \\
\hline
\end{tabular}

YES = the remedial alternative meets the threshold criterion

$\mathrm{NO}=$ the remedial alternative does not meet the threshold criterion

Note: The threshold criterion, Source Control, is not included since a secondary source of release is not present in the vadose zone or saturated zone at TA-V.

Table 3-7. Quantitative analysis of remedial alternatives for TA-V.

\begin{tabular}{|c|c|c|c|c|c|c|c|c|}
\hline \multirow{2}{*}{\multicolumn{2}{|c|}{$\begin{array}{c}\text { Remedial } \\
\text { Alternatives }\end{array}$}} & \multirow[b]{2}{*}{ 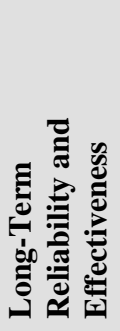 } & \multirow{2}{*}{ 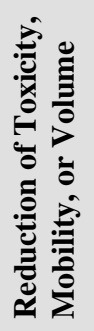 } & \multirow[b]{2}{*}{ 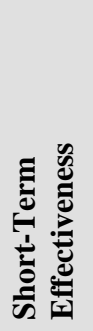 } & \multirow[b]{2}{*}{ 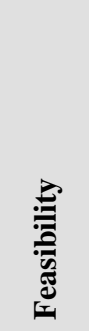 } & \multicolumn{2}{|c|}{ Cost } & \multirow[b]{2}{*}{ Totals } \\
\hline & & & & & & 휼 & 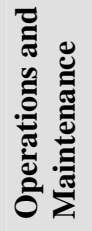 & \\
\hline MNA $f$ & and Nitrate & ++ & ++ & + & +++ & +++ & ++ & 13 \\
\hline $\begin{array}{l}\text { ISB for } \\
\text { and MI }\end{array}$ & $\begin{array}{l}\text { ad Nitrate } \\
\text { OCs }\end{array}$ & ++ & +++ & ++ & + & + & + & 10 \\
\hline $\begin{array}{l}\text { “+” } \\
\text { “++" } \\
\text { “+++"” }\end{array}$ & $\begin{array}{l}\text { Meets the rem } \\
\text { Effectively me } \\
\text { More effective }\end{array}$ & $\begin{array}{l}\text { ial alternati } \\
\text { s the remed } \\
\text { meets the } \mathrm{r}\end{array}$ & $\begin{array}{l}\text { iterion. } \\
\text { ternative } \\
\text { dial altern }\end{array}$ & $\begin{array}{l}\text { rion. } \\
\text { e criterion }\end{array}$ & & & & \\
\hline
\end{tabular}


Table 3-8. Information supporting quantitative remedial alternatives evaluation.

\begin{tabular}{|c|c|c|c|c|c|c|}
\hline \multirow[b]{2}{*}{$\begin{array}{c}\text { Remedial } \\
\text { Alternatives }\end{array}$} & \multirow[b]{2}{*}{ 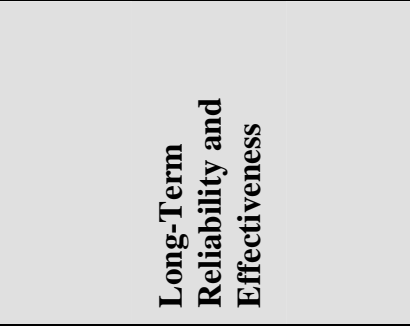 } & \multirow[b]{2}{*}{ 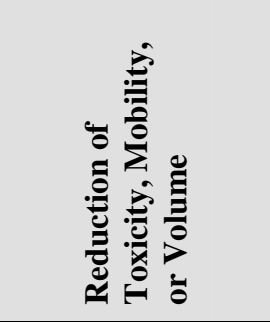 } & \multirow[b]{2}{*}{ 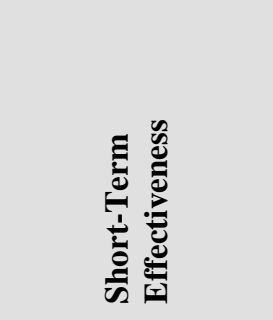 } & \multirow[b]{2}{*}{ 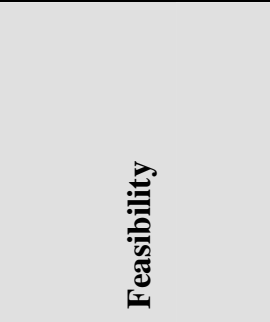 } & \multicolumn{2}{|c|}{ Cost } \\
\hline & & & & & 预 & 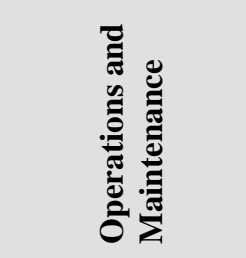 \\
\hline $\begin{array}{l}\text { MNA for } \\
\text { VOCs and } \\
\text { Nitrate }\end{array}$ & $\begin{array}{l}\text { Advantage: Natural attenuation } \\
\text { processes are operable as } \\
\text { demonstrated by (1) } \\
\text { biodegradation (direct evidence } \\
\text { of intrinsic aerobic } \\
\text { cometabolism of TCE) and (2) } \\
\text { dilution (estimates that COC } \\
\text { concentrations will be diluted by } \\
\text { approximately four orders of } \\
\text { magnitude before reaching } \\
\text { potential receptors). } \\
\text { Disadvantage: Long-term } \\
\text { monitoring will be required } \\
\text { because COCs will be left in } \\
\text { place. }\end{array}$ & $\begin{array}{l}\text { Advantage: Results } \\
\text { of field studies } \\
\text { show direct } \\
\text { evidence of } \\
\text { intrinsic aerobic } \\
\text { cometabolism of } \\
\text { TCE. } \\
\text { Disadvantage: The } \\
\text { remedial timeframe } \\
\text { may be longer } \\
\text { compared to the } \\
\text { ISB for VOCs and } \\
\text { Nitrate and MNA } \\
\text { for VOCs } \\
\text { alternative. }\end{array}$ & $\begin{array}{l}\text { Disadvantage: This } \\
\text { remedial alternative } \\
\text { relies on natural } \\
\text { attenuation } \\
\text { mechanisms, which } \\
\text { are not effective in } \\
\text { the short term, but } \\
\text { are effective over } \\
\text { longer periods of } \\
\text { time. }\end{array}$ & $\begin{array}{l}\text { Advantage: This } \\
\text { remedial alternative } \\
\text { is ready to } \\
\text { implement } \\
\text { immediately. }\end{array}$ & $\begin{array}{l}\text { Advantage: Wells } \\
\text { and equipment } \\
\text { already exist. }\end{array}$ & $\begin{array}{l}\text { Advantage: The } \\
\text { only operations } \\
\text { requirements are } \\
\text { monitoring and } \\
\text { well maintenance. } \\
\text { Disadvantage: } \\
\text { Monitoring wells } \\
\text { may need to be } \\
\text { replaced over the } \\
\text { remedial } \\
\text { timeframe, which } \\
\text { may be longer than } \\
\text { ISB for VOCs and } \\
\text { Nitrate and MNA } \\
\text { for VOCs } \\
\text { alternative. }\end{array}$ \\
\hline $\begin{array}{l}\text { ISB for VOCs } \\
\text { and Nitrate } \\
\text { and MNA for } \\
\text { VOCs }\end{array}$ & $\begin{array}{l}\text { Advantage: Successful } \\
\text { implementation of ISB would } \\
\text { degrade contaminants within a } \\
\text { high concentration zone faster } \\
\text { than MNA. } \\
\text { Disadvantage: ISB would only } \\
\text { be successful and reliable if } \\
\text { distribution of an amendment is } \\
\text { achieved; the probability of } \\
\text { remedy failure is higher than } \\
\text { MNA. }\end{array}$ & $\begin{array}{l}\text { Advantage: If ISB } \\
\text { is successfully } \\
\text { implemented, then } \\
\text { COCs will be } \\
\text { reduced at a faster } \\
\text { rate than MNA. }\end{array}$ & $\begin{array}{l}\text { Advantage: If ISB } \\
\text { is successfully } \\
\text { implemented, then } \\
\text { there will be } \\
\text { significant short- } \\
\text { term effectiveness in } \\
\text { reducing COC } \\
\text { concentrations. }\end{array}$ & $\begin{array}{l}\text { Disadvantage: This } \\
\text { remedial alternative } \\
\text { requires the } \\
\text { construction of } \\
\text { significant } \\
\text { infrastructure. Even } \\
\text { under the most } \\
\text { favorable observed } \\
\text { site conditions } \\
\text { distribution of } \\
\text { electron donor will } \\
\text { be technically } \\
\text { difficult. }\end{array}$ & $\begin{array}{l}\text { Disadvantage: } \\
\text { Implementation of } \\
\text { ISB requires } \\
\text { construction of } \\
\text { new injection } \\
\text { well(s) and } \\
\text { injection } \\
\text { equipment. }\end{array}$ & $\begin{array}{l}\text { Advantage: Over } \\
\text { the remedial } \\
\text { alternative lifetime } \\
\text { ISB may require } \\
\text { less monitoring } \\
\text { than MNA. } \\
\text { Disadvantage: } \\
\text { Requires purchase } \\
\text { of large amounts of } \\
\text { amendments and } \\
\text { extensive } \\
\text { operations. }\end{array}$ \\
\hline
\end{tabular}




\subsection{Selection of a Preferred Remedial Alternative}

Based on the quantitative evaluation results, the preferred remedial alternative for implementation as the corrective measure for TA-V groundwater is MNA for VOCs and Nitrate. The qualitative results of the threshold criteria qualitative evaluation (Table 3-6) demonstrated that both remedial alternatives met these criteria. The quantitative results of evaluation using the remedial alternative criteria (Table 3-7) demonstrated that MNA for VOCs and Nitrate is the preferred remedial alternative (with a numerical ranking of 13 out of a possible score of 18).

Advantages and disadvantages for each remedial alternative that support quantitative evaluation using the remedial alternative criteria are provided in Table 3-8. Overall, the reasons for selecting MNA for VOCs and Nitrate as the preferred remedial alternative include:

- Numerical modeling results provide evidence that there is no unacceptable risk to potential receptors,

- There is direct evidence that a natural attenuation mechanism (aerobic biodegradation of TCE) is present in TA-V groundwater,

- The MNA for VOCs and Nitrate remedial alternative is appropriate for TA-V groundwater, as determined using policies and guidance set forth by EPA (1999) and the DOE (1999) (see Section 3.2.1),

- The risk of failure for the ISB for VOCs and Nitrate and MNA for VOCs remedial alternative is greater than the MNA for VOCs and Nitrate alternative,

- The ISB for VOCs and Nitrate and MNA for VOCs remedial alternative has higher capital costs due to construction and amendments,

- Even if the most favorable conditions for ISB implementation exist, effective distribution of electron donor in this low-permeability aquifer is less feasible than an MNA only remedial alternative (see Section 3.2.2).

In addition, the preferred remedial alternative, MNA for VOCs and Nitrate, meets the following criteria stated in the COOC (NMED 2004):

- Protective of human health and the environment - This remedial alternative will be protective of human health and the environment for the following reasons: (1) aerobic biodegradation mechanisms that do not have potential hazardous degradation products have been identified; (2) numerical modeling has shown, even without considering biodegradation, that contaminants will be reduced to several orders of magnitude below MCLs before reaching receptors; and (3) remediation will occur in situ and operations and maintenance activities will only consist of regular monitoring activities, which will reduce risk of potential exposure to contaminants.

- Will attain media cleanup standards - This remedial alternative will meet the cleanup goals and objectives identified for TA-V, as stated in Section 4.

- Will comply with any applicable standards for waste management - This remedial alternative will comply with applicable waste management standards for all waste generated during the life cycle of the remedy and during final decommissioning of the remedy system. 


\subsection{REMEDIAL ALTERNATIVE DESIGN CRITERIA TO MEET CLEANUP GOALS AND OBJECTIVES}

The remedial alternative strategy for MNA of VOCs and Nitrate identifies T\&FRs and itemized cost elements. This strategy was developed during the CME process and will be expanded and further developed in the CMI Plan.

MNA of VOCs and Nitrate was selected as the corrective measure for TA-V groundwater. Cleanup goals and objectives are criteria used to evaluate performance and can be divided into two types (performance and compliance) based on when the goal or objective is to be achieved. Goals are established as the milestones to meet upon completion of remediation. Objectives are tasks to be completed in order to meet the goals.

Performance goals and objectives are defined to support remedy performance evaluation during implementation and before final closure of the site. Compliance goals and objectives are defined to support decision making at the end of the remedy and to provide the framework for determining whether the remedy has restored groundwater to beneficial use within the restoration timeframe. Because the type of data collected may be quite different, it is important to distinguish between performance and compliance goals and objectives. The performance and compliance goals and objectives for TA-V groundwater were developed in the TA-V CME Work Plan (SNL/NM 2004a) and are also stated below.

\subsection{Performance Goals and Objectives}

Performance goals and objectives are criteria and actions used to evaluate remedy performance during the operations phase to support evaluation of system performance data relative to end-state objectives. Performance monitoring data analysis leads to periodic decisions that the remedy is performing as expected and that the remedy will ultimately achieve the final remediation goal. The performance goals and objectives for TA-V groundwater include:

\section{Performance Goals:}

- Establishing and operating a remedy intended to reduce COC concentrations,

- Monitoring distribution and changes in COC concentrations, and

- Collecting sufficient data to support a decision to move into the compliance phase.

Performance Objectives:

- Collecting groundwater samples for performance parameters (in addition to COCs) from TA-V wells,

- Compiling and analyzing groundwater monitoring data to evaluate trends in COC concentrations,

- Comparing trends to the COC cleanup standards, and

- Recommending continued operation of the remediation system or strategy and proceeding to compliance evaluation. 


\subsection{Compliance Goals and Objectives}

Compliance goals and objectives are criteria and actions used to evaluate remediation system or strategy effectiveness both during and at completion of the corrective measure. Compliance requirements may be imposed during remediation system or strategy operations (e.g., air emissions or waste management). In addition, compliance requirements exist for final closure of the site. These compliance goals and objectives serve to show that (1) the remedy is being implemented in a fashion that is consistent with the COOC (NMED 2004) during implementation and (2) the remedy has accomplished the remediation goals at the end of the corrective measure. Groundwater cleanup levels for TA-V are defined in Section VI.K.1.a of the COOC as the more restrictive of EPA MCLs or Water Quality Control Commission (WQCC) standards. The cleanup levels for COCs at TA-V are defined by the MCLs, as these are the more restrictive of the two standards. The remedial timeframe for TA-V will be defined in the CMI Plan. The compliance goals and objectives for TA-V groundwater include:

Compliance Goals:

- Operating all remediation systems or strategies in compliance with applicable requirements,

- Reducing COC concentrations throughout the plume to below MCLs, and

- Implementing institutional controls to protect human health and the environment during the remediation timeframe.

Compliance Objectives:

- Monitoring all remediation systems or strategies for compliance with applicable requirements,

- Collecting groundwater samples at TA-V wells for COCs,

- Comparing COC concentrations to cleanup standards, and

- Recommending site closure or continuation of long-term operations. 


\subsection{CORRECTIVE MEASURES IMPLEMENTATION PLAN}

As stated in the Section VII.D.2 of the COOC (NMED 2004), the CMI Plan will outline the "design, construction, operation, maintenance, and performance monitoring for the selected remedy, and a schedule for implementation.”

\subsection{Corrective Measures Implementation Plan Outline}

The following is a draft outline of the key components of the CMI Plan and includes the required CMI Plan elements listed in the COOC. Some of the elements stated in the COOC, such as results of pilot tests, construction work plan, and engineering design drawings and specifications, are not included in this outline because they are not applicable to the MNA for VOCs and Nitrate remedial alternative. The outline is as follows:

I. Introduction

II. Background Information

III. Description of Selected Final Remedy

a. Remediation system objectives and cleanup goals

IV. Remedy Implementation
a. Implementation Team qualifications
b. Operation and Maintenance Plan
c. Waste Management Plan

V. Remedy Performance Monitoring
a. Sampling
b. Contingency

VI. Schedule
a. Implementation schedule
b. Reporting schedule

VII. Appendices. 


\subsection{Corrective Measures Implementation Schedule}

The basis for the CMI schedule (Figure 5-1) is the logical development of project tasks and activities, which will support the implementation of corrective measures under the COOC. This schedule includes corrective measure tasks and milestones. This CME Report and the CMI Plan require NMED review and approval. These documents are identified deliverables and have clearly defined agency review and comment resolution periods (Table 5-1). SNL/NM will proceed at risk with the corrective measures implementation, as outlined in the schedule.

Table 5-1. Summary of TA-V documents and delivery dates.

\begin{tabular}{l|l}
\hline \multicolumn{1}{c|}{ Document } & \multicolumn{1}{c}{ Delivery Date } \\
\hline TA-V CME Work Plan & $\begin{array}{l}\text { Completed and submitted to NMED in April 2004; } \\
\text { comments were received and incorporated in November } \\
\text { 2004; the final document was submitted to NMED in } \\
\text { December 2004. }\end{array}$ \\
\hline TA-V Current Conceptual Model & $\begin{array}{l}\text { Completed and submitted to NMED in April 2004; } \\
\text { comments were received and incorporated in November } \\
\text { 2004; the final document was submitted to NMED in } \\
\text { December 2004. }\end{array}$ \\
\hline $\begin{array}{l}\text { TA-V Remedial Alternatives Data } \\
\text { Gaps Review }\end{array}$ & Completed September 2004 \\
\hline $\begin{array}{l}\text { TA-V Evaluation of an Intrinsic } \\
\text { Aerobic Biodegradation } \\
\text { Mechanism }\end{array}$ & Completed April 2005 \\
\hline $\begin{array}{l}\text { TA-V Evaluation of Intrinsic } \\
\text { Anaerobic Biodegradation }\end{array}$ & Completed July 2004 \\
\hline $\begin{array}{l}\text { TA-V Evaluation of Contaminant } \\
\text { Transport in Groundwater }\end{array}$ & Completed March 2005 \\
\hline TA-V CME Report & Planned early submittal to NMED in July 2005. \\
\hline $\begin{array}{l}\text { TA-V Corrective Measures } \\
\text { Implementation Plan }\end{array}$ & $\begin{array}{l}\text { Currently on schedule to meet 9/30/06 NMED submittal } \\
\text { date. }\end{array}$ \\
\hline
\end{tabular}




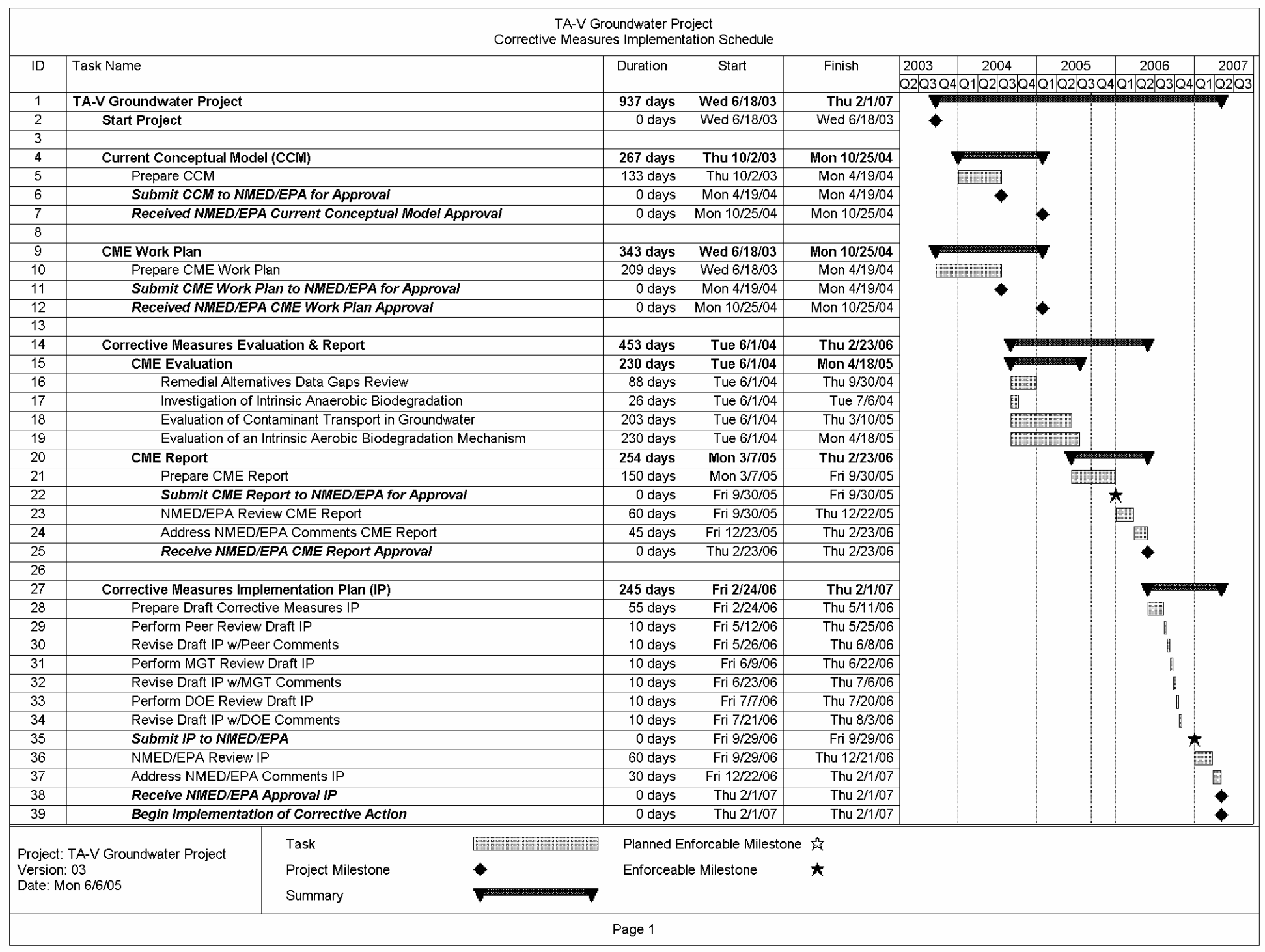

Figure 5-1. Corrective measures implementation schedule. 


\subsection{REFERENCES}

1. 40 CFR 141.61, 2002, Title 40, "Protection of Environment," Subchapter D, "Water Programs," Part 141, "National Primary Drinking Water Regulations," Section .61, "Maximum Contaminant Levels for Organic Contaminants," Code of Federal Regulations, Office of the Federal Register.

2. 40 CFR 141.62, 2002, Title 40, "Protection of Environment," Subchapter D, "Water Programs,” Part 141, "National Primary Drinking Water Regulation,” Section .62, "Maximum Contaminant Levels for Inorganic Contaminants," Code of Federal Regulations, Office of the Federal Register.

3. DOE 1999, Decision-Making Framework Guide for the Evaluation and Selection of Monitored Natural Attenuation Remedies at Department of Energy Sites, Department of Energy, Office of Environmental Restoration, May 1999.

4. EPA, 1999, Use of Monitored Natural Attenuation at Superfund, RCRA Corrective Action, and Underground Storage Tank Sites, OSWER Directive 9200.4-17P, http://www.epa.gov/swerust1/directiv/d9200417.pdf.

5. EPA, 1998, Technical Protocol for Evaluating Natural Attenuation of Chlorinated Solvents in Ground Water, EPA/600/R-98/128, http://www.clu-in.org/download/remed/protocol.pdf., September 1998.

6. EPA, 1994, RCRA Corrective Action Plan (Final), OSWER 9902.3-2A, U.S. Environmental Protection Agency, Office of Solid Waste and Emergency Response, May 1994.

7. NMED, 2004, "Compliance Order on Consent Pursuant to the New Mexico Hazardous Waste Act 74-4-10: Sandia National Laboratories Consent Order,” New Mexico Environment Department, April 24, 2004.

8. SNL/NM, 2004a, Corrective Measures Evaluation Work Plan Technical Area-V Groundwater, SAND2004-1471, April 2004, Sandia National Laboratories/New Mexico.

9. SNL/NM, 2004b, Current Conceptual Model of Groundwater Flow and Contaminant Transport at Sandia National Laboratories/New Mexico Technical Area-V, SAND2004-1470, April 2004, Sandia National Laboratories/New Mexico.

10. SNL/NM, 2005a, Annual Groundwater Monitoring Report, Fiscal Year 2004. Groundwater Protection Program Sandia National Laboratories, New Mexico. anticipated July 2005.

11. SNL/NM, 2005b, Environment, Safety, and Health (ES\&H) Manual, CPR400.1.1, MN471001, Issue EZ, revision date May 31, 2005, Sandia National Laboratories, Albuquerque, New Mexico.

12. SNL/NM, 1999, SNL/NM Summary Report of Groundwater Investigations at Technical Area V, Operable Units 1306 and 1307, Environmental Restoration Project, U.S. Department of Energy, Albuquerque Operations Office, Sandia National Laboratories/New Mexico, March 1999. 
Attachment A

Conceptual Model Update:

Contaminant Distribution in Groundwater 
This Page Intentionally Left Blank 


\subsection{CONCEPTUAL MODEL UPDATE: CONTAMINANT DISTRIBUTION IN GROUNDWATER}

Section 3.3.3 of the Current Conceptual Model of Groundwater Flow and Contaminant Transport at Sandia National Laboratories/New Mexico Technical Area V (SNL/NM 2004b) presented concentrations of the contaminants of concern (COCs) in Technical Area-V (TA-V) groundwater. During the course of the Corrective Measures Evaluation (CME) quarterly groundwater monitoring from these wells has continued, and data plots originally presented in the Current Conceptual Model were updated with data from Fiscal Year (FY)-2003 and FY-2004 (SNL/NM 2004a, SNL/NM 2005).

The groundwater monitoring well network is shown on Figure A-1. Figures A-2, A-3, and A-4 are updated plots of concentration for the three COCs at TA-V, trichloroethene (TCE), tetrachloroethene (PCE), and nitrate. Non-detect results are not shown in these plots.

Concentration trends remain consistent with the stable to declining trends described in the Current Conceptual Model (SNL/NM 2004b).

TCE in LWDS-MW1 appears to have stabilized with the maximum concentration detected in a sample collected in November of 2000. These concentrations are expected to remain stable as there is no ongoing source of contaminants, and will decrease in the future as natural attenuation mechanisms act on the TCE. Concentrations of PCE and nitrate have also remained stable or declined. Nitrate is widely distributed across the site at concentrations below the MCL. Groundwater in the vicinity of LWDS-MW1 has the highest detections of nitrate at TA-V. However, nitrate concentrations in samples from this well have been stable since 2002

(Figure A-4). PCE concentrations in well TAV-MW7 have been declining since 2002. PCE concentrations have been below the MCL since 2003 and below the detection limit since 2004 (Figure A-3) 
This Page Intentionally Left Blank 


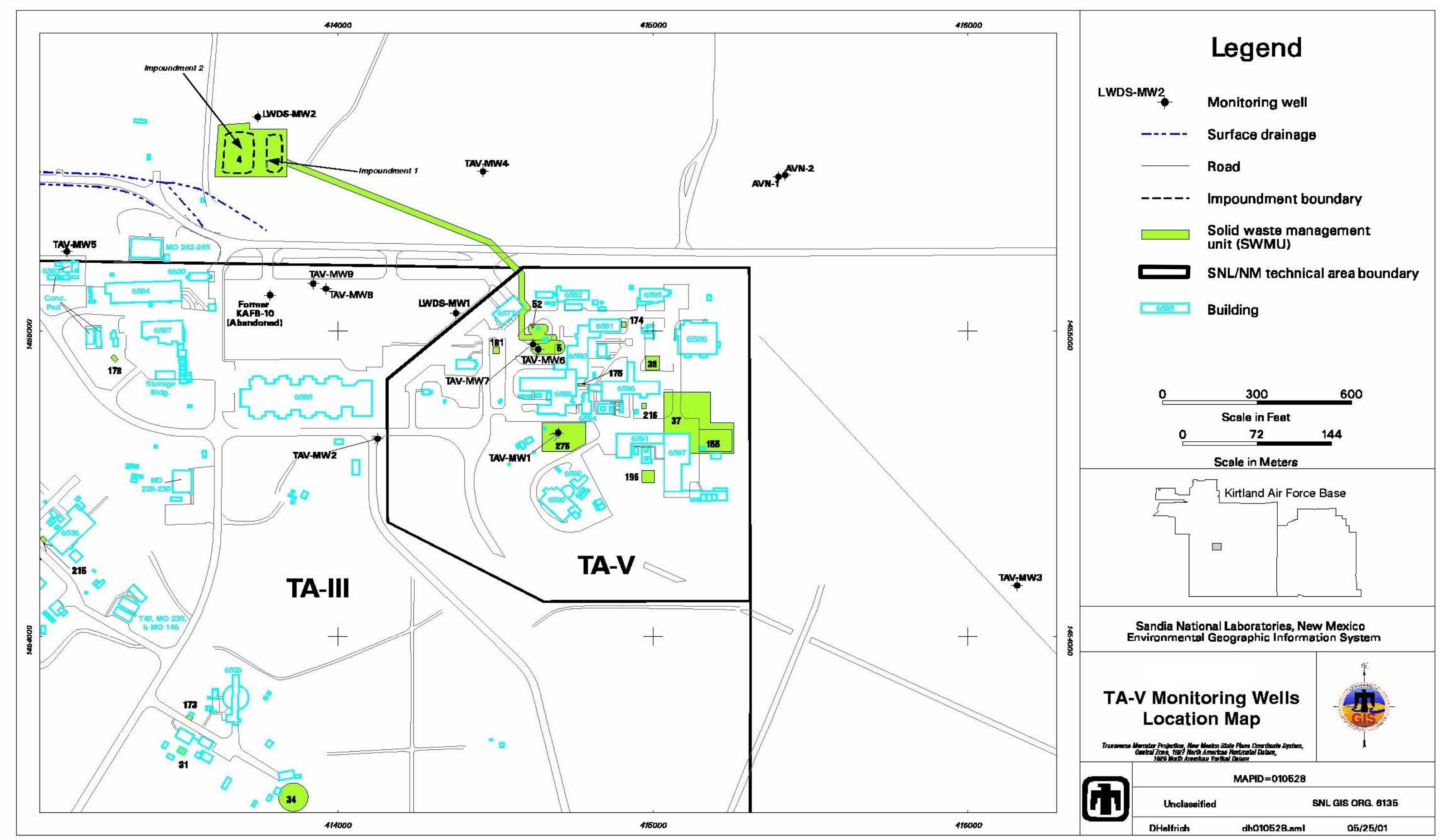

Figure A-1. Location of groundwater monitoring wells in the vicinity of SNL/NM TA-V. 
This Page Intentionally Left Blank 


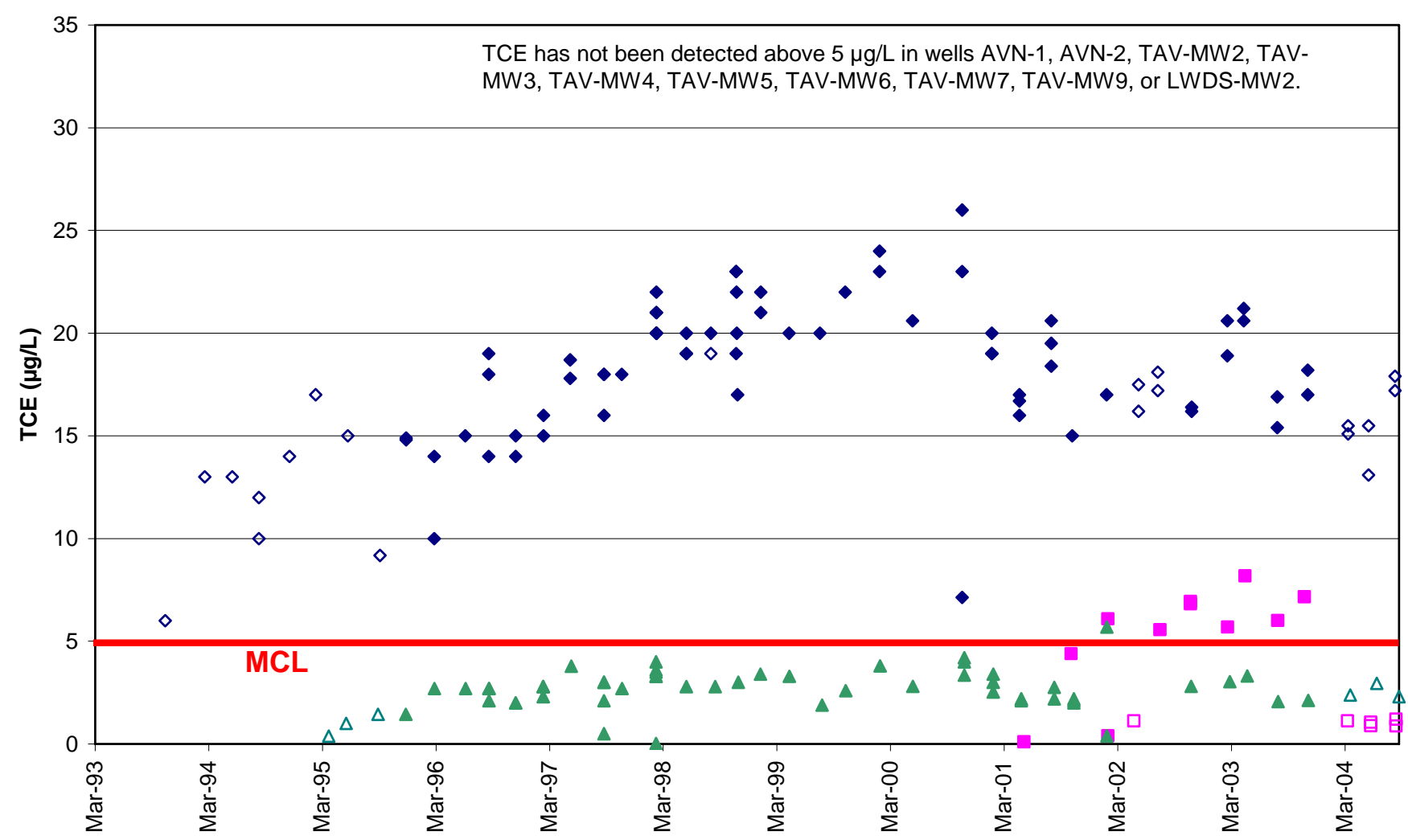

- LWDS-MW1 (using low flow sampling)

$\diamond$ LWDS-MW1 (using high flow sampling)

- TAV-MW8 (using low flow sampling)

口TAV-MW8 (using high flow sampling)

$\triangle \mathrm{TAV}-\mathrm{MW} 1$ (using low flow sampling)

$\triangle$ TAV-MW1 (using high flow sampling)

Figure A-2. TCE concentrations over time at selected TA-V wells. 


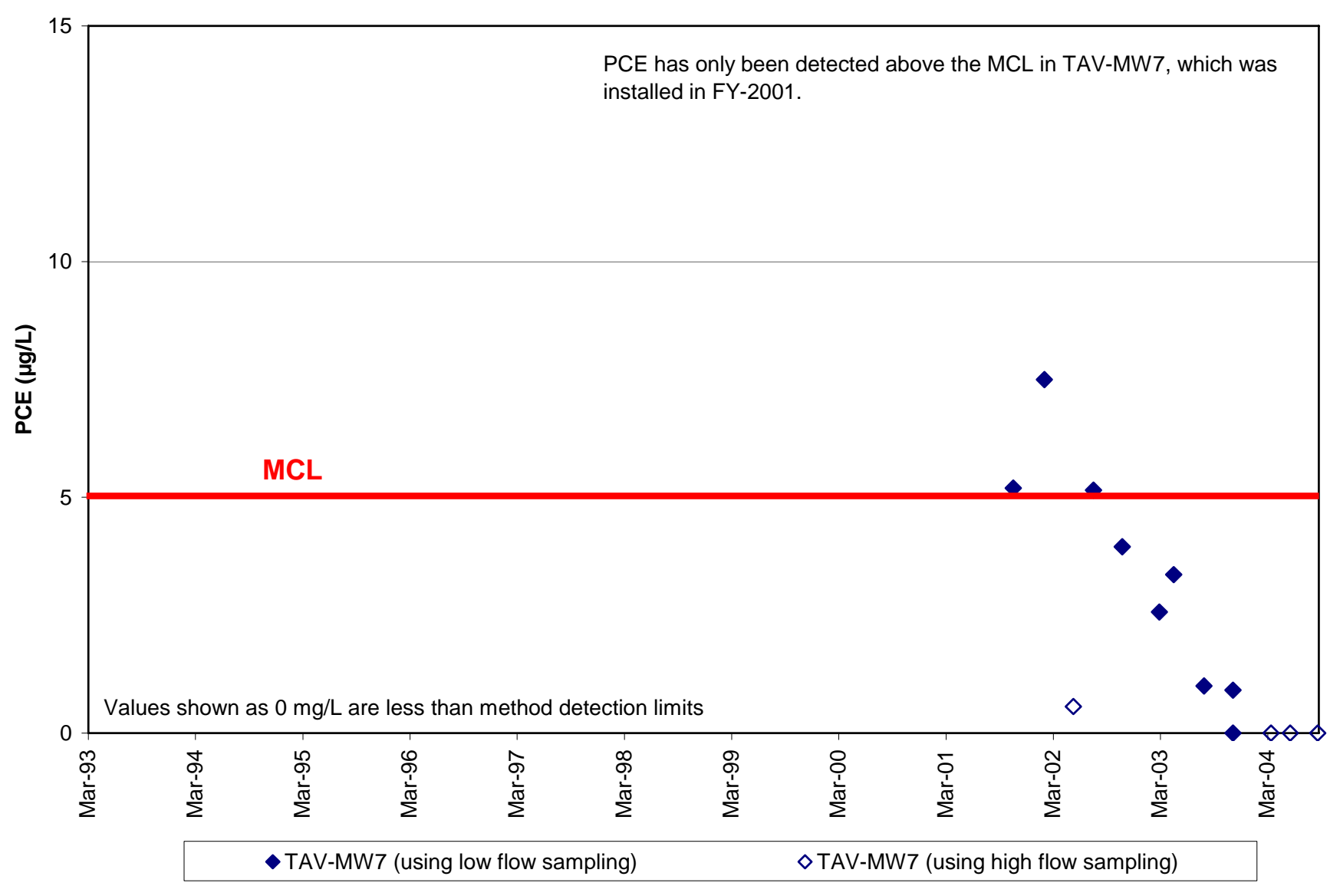

Figure A-3. PCE detections over time at selected TA-V wells. 


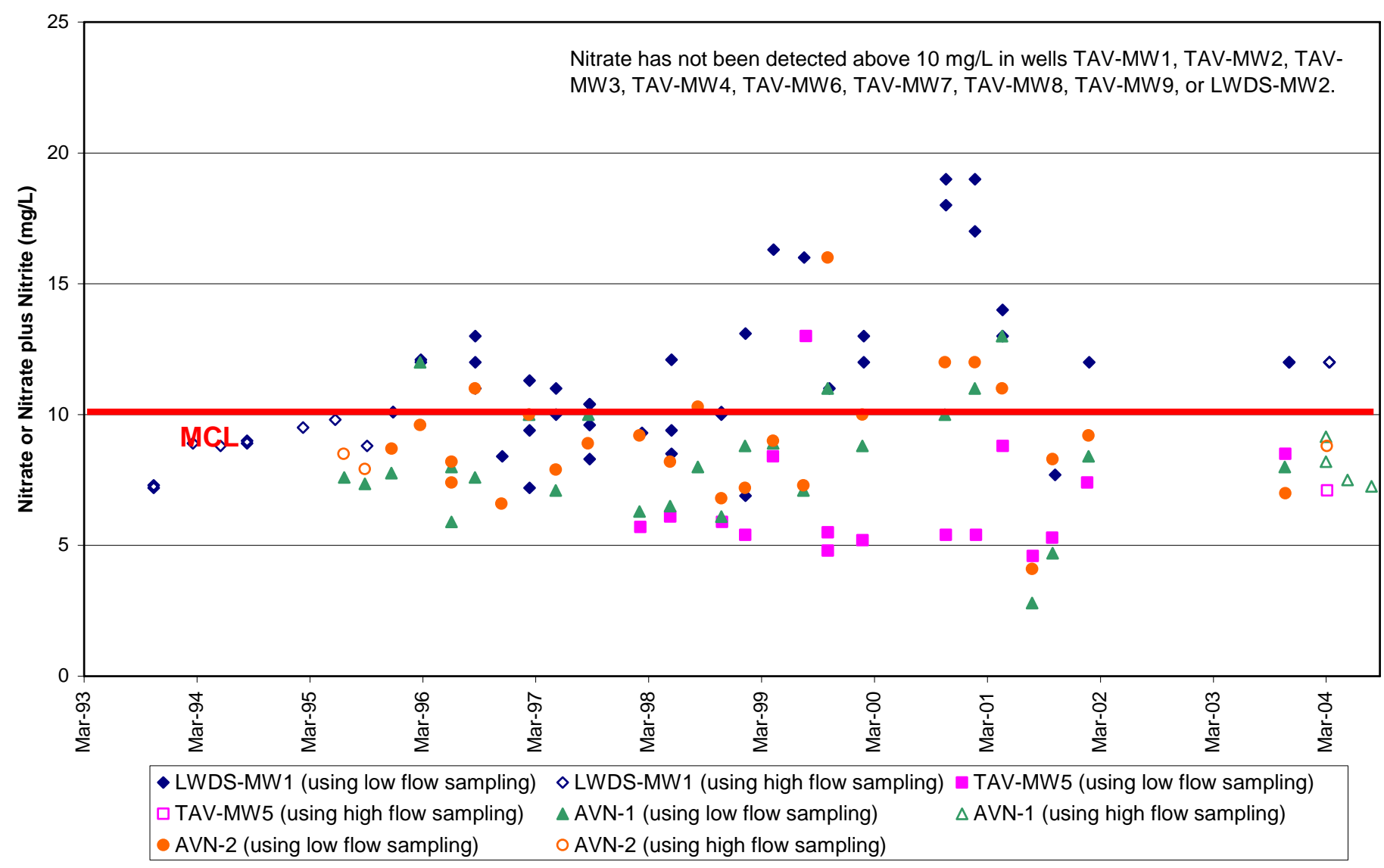

Figure A-4. Nitrate concentrations over time at selected TA-V wells. 
This Page Intentionally Left Blank 


\subsection{REFERENCES}

1. SNL/NM, 2004a, Annual Groundwater Monitoring Report, Fiscal Year 2003. Groundwater Protection Program Sandia National Laboratories, New Mexico. March 2004.

2. SNL/NM, 2004b, Current Conceptual Model of Groundwater Flow and Contaminant Transport at Sandia National Laboratories/New Mexico Technical Area-V, SAND2004-1470, April 2004, Sandia National Laboratories/New Mexico.

3. SNL/NM, 2005, Annual Groundwater Monitoring Report, Fiscal Year 2004. Groundwater Protection Program Sandia National Laboratories, New Mexico. anticipated July 2005. 
This Page Intentionally Left Blank

A-12 
Attachment B

Remedial Alternatives Data Gaps Review

B-1 
This Page Intentionally Left Blank

B-2 


\title{
Remedial Alternative Data Gaps Review for Technical Area-V Groundwater at Sandia National Laboratories/New Mexico
}

\author{
September 2004
}

Prepared by

Sandia National Laboratories

Albuquerque, New Mexico 87185 and Livermore, California 94550

Sandia is a multiprogram laboratory operated by Sandia Corporation,

a Lockheed Martin Company, for the United States Department of Energy’s

National Nuclear Security Administration under Contract DE-AC04-94AL85000.

Approved for public release; further dissemination unlimited.

\section{i. Sandia National Laboratories}




\begin{abstract}
The objective of this document is to continue the assessment of alternative technologies to support the Corrective Measures Evaluation (CME) process for remediation of Technical Area-V (TA-V) groundwater. This Remedial Alternative Data Gap Review is an informal report that documents decisions made as a result of the assessment and recommends activities to address the data gaps and provide sufficient information to complete the CME Report. Nine remedial alternatives were identified in the TA-V CME Work Plan. The nine remedial alternatives are:
\end{abstract}

1. Groundwater monitoring for volatile organic compounds (VOCs) and nitrate,

2. Monitored natural attenuation (MNA) for VOCs and nitrate,

3. MNA for VOCs and groundwater monitoring for nitrate,

4. In situ bioremediation (ISB) followed by MNA for VOCs and nitrate,

5. ISB followed by MNA for VOCs and groundwater monitoring for nitrate,

6. ISB followed by MNA for VOCs and MNA for nitrate,

7. Pump-and-treat followed by MNA for VOCs and nitrate,

8. Pump-and-treat followed by MNA for VOCs and groundwater monitoring for nitrate, and

9. Pump-and-treat followed by MNA for VOCs and MNA for nitrate.

Section 2 of this document includes more detailed descriptions of the technologies used in the nine remedial alternatives presented in the TA-V CME Work Plan. With the information presented in these more detailed descriptions, the nine remedial alternatives were reduced to six. Conceptual designs for these six remedial alternatives are presented. The conceptual designs are used to perform a preliminary remedial alternative evaluation based on the threshold and remedial alternative evaluation criteria from the Compliance Order on Consent. Based on this assessment, it is recommended that two remedial alternatives no longer be considered.

Recommended data gathering activities for the remaining four alternatives include numerical modeling and field studies. 


\section{CONTENTS}

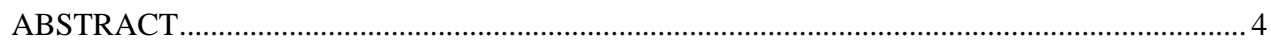

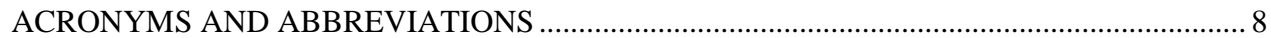

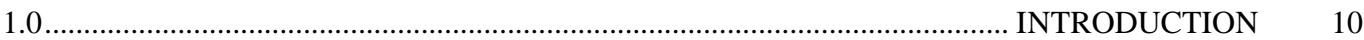

1.1 CME Interim Documentation ……....................................................................10

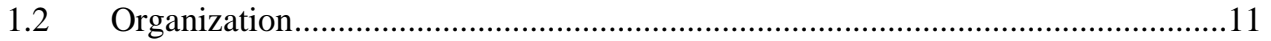

1.3 Site Conceptual Model Information........................................................................13

1.3.1 Contaminant Releases 13

1.3.2 Contaminant Transport through the Vadose Zone 15

1.3.3 Contaminant Distribution in Groundwater 16

1.3.4 Adequacy of the Monitoring Network to Evaluate the Distribution of Contaminants 18

1.3.5 Information Compiled during the Paper Study 22

2.0 .TECHNOLOGY DESCRIPTIONS

2.1 Technical Description of Groundwater Monitoring

2.1.1 Considerations for Evaluation of Groundwater Monitoring 24

2.1.2 Implementation of Groundwater Monitoring at TA-V 24

2.2 Technical Description of Monitored Natural Attenuation

2.2.1 Considerations for Evaluation of MNA 25

2.2.2 Implementation of MNA at TA-V 26

2.2.3 Natural Attenuation Mechanisms 27

2.3 Technical Description of In Situ Bioremediation ...... .28

2.3.1 Considerations for Evaluation of ISB 30

2.3.2 Implementation of ISB Technology at TA-V 30

2.4 Technical Description of Pump and Treat 31

2.4.1 Considerations for Evaluation of Pump and Treat 32

2.4.2 Considerations for Implementing Pump and Treat at TA-V 32

2.4.3 Scoping Pumping Requirements at TA-V 32

2.4.4 Scoping Treatment Options 34

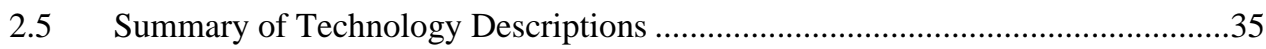


3.1. Groundwater Monitoring for VOCs and Nitrate.....

3.1.1 Technical and Functional Requirements 36

3.1.2 Cost 38

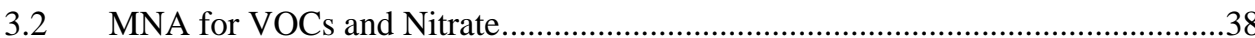

3.2.1 Technical and Functional Requirements 39

3.2.2 Cost 40

3.3 MNA for VOCs and Groundwater Monitoring for Nitrate.................................40

3.4 ISB for VOCs and Nitrate and MNA for VOCs ..............................................41

3.4.1 Technical and Functional Requirements 41

3.4.2 Cost 43

3.5 Pump and Treat for VOCs and Nitrate using GAC and Ion-Exchange ................43

3.5.1 Technical and Functional Requirements 43

3.5.2 Cost 44

3.6 Pump and Treat for VOCs using GAC and Groundwater Monitoring for Nitrate 44

4.0 PRELIMINARY REMEDIAL ALTERNATIVE EVALUATION

4.1 Threshold Criteria Evaluation.

4.2 Remedial Alternative Evaluation. .47

4.3 Summary of the Preliminary Remedial Alternative Evaluation .53

5.0 RECOMMENDATIONS FOR FURTHER STUDIES 55

6.0 REFERENCES

58

Appendix B. Scoping Calculations for Implementation of ISB

Appendix C. Scoping Estimates of Operations and Timeframe for Pump and Treat Appendix D. Treatment and Disposal Options for Pump and Treat 


\section{FIGURES}

1-1. Illustration of the staged process of data gathering with potential activities and subsequent reports.

1-2. Key elements of the current conceptual model of contaminant transport at SNL/NM

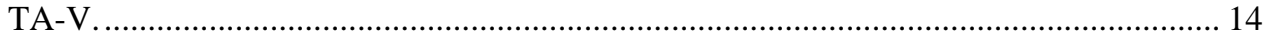

1-3. Location of groundwater monitoring wells in the vicinity of SNL/NM TA-V............. 20

1-4. Water level measurements in TA-V wells during 1993-2000 (SNL/NM 2004b)........... 22

2-1. Decision framework for evaluating MNA (from DOE 1999). ........................................ 26

2-2. Energy available from typical microbially mediated redox reactions, and their relationship to reductive dechlorination.............................................................. 29

3-1. Process diagram for groundwater monitoring for VOCs and nitrate............................ 36

3-2. $\quad$ Process diagram for MNA for VOCs and nitrate................................................... 38

3-3. Process diagram for ISB for VOCs and nitrate and MNA for VOCs........................... 41

3-4. Process diagram for implementation of pump and treat for VOCs and nitrate. .............. 44

4-1. Changes in remedial alternatives for TA-V groundwater............................................ 54

\section{TABLES}

1-1. Predicted depth (ft) of the saturated thickness in TA-V monitoring wells by year. ......... 23

2-1. Groundwater monitoring operational phases................................................................. 25

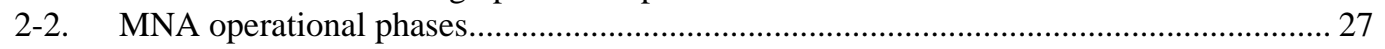

2-3. Summary of pump-and-treat estimates................................................................. 33

3-1. T\&FRs for groundwater monitoring for VOCs and nitrate. ..................................... 37

3-2. Itemized cost elements for the groundwater monitoring for VOCs and nitrate remedial

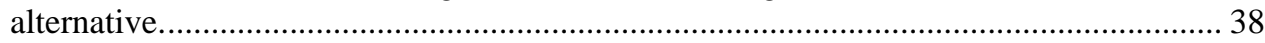

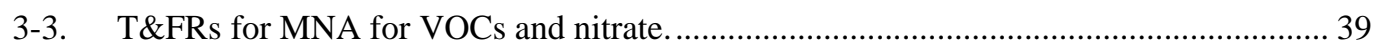

3-4. Itemized costs for the MNA for VOCs and nitrate remedial alternative........................ 40

3-5. T\&FRs for ISB for VOCs and nitrate and MNA for VOCs. ...................................... 42

3-6. Itemized costs for the ISB and MNA for VOCs and ISB for nitrate remedial alternative.

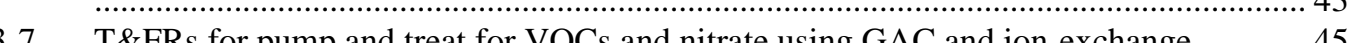

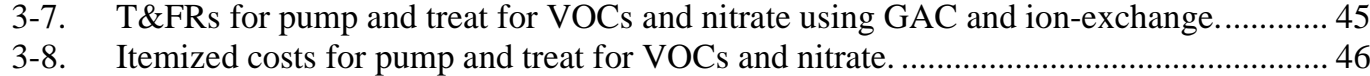

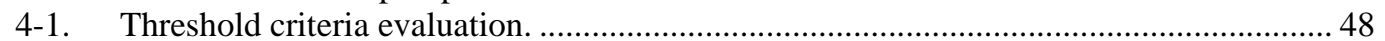

4-2. Information supporting comparative analysis of the remedial alternatives.................... 49

4-3. Comparative analysis of remedial alternatives for TA-V .......................................... 52

5-1. $\quad$ Recommended numerical modeling, field, and laboratory studies............................... 56 


\section{ACRONYMS AND ABBREVIATIONS}

$\begin{array}{ll}\text { ARD } & \text { anaerobic reductive dechlorination } \\ \text { ARG } & \text { ancestral Rio Grande } \\ \text { CME } & \text { Corrective Measures Evaluation } \\ \text { COA } & \text { City of Albuquerque } \\ \text { COC } & \text { contaminant of concern } \\ \text { COOC } & \text { Compliance Order on Consent } \\ \text { DCE } & \text { dichlororethene } \\ \text { DOE } & \text { United States Department of Energy } \\ \text { DOE-ID } & \text { United States Department of Energy Idaho Operations Office } \\ \text { EPA } & \text { United States Environmental Protection Agency } \\ \text { ft } & \text { foot or feet } \\ \text { ft/min } & \text { feet per minute } \\ \text { ft/yr } & \text { feet per year } \\ \text { GAC } & \text { granular activated carbon } \\ \text { gal } & \text { gallon } \\ \text { gpm } & \text { gallons per minute } \\ \text { gPm/ft } & \text { gallons per minute per foot } \\ \text { ISB } & \text { in-situ bioremediation } \\ \text { KAFB } & \text { Kirtland Air Force Base } \\ \text { LWDS } & \text { Liquid Waste Disposal System } \\ \text { MCL } & \text { maximum contaminant level } \\ \text { MNA } & \text { monitored natural attenuation } \\ \text { MMO } & \text { methane monooxygenase } \\ \text { NMED } & \text { New Mexico Environmental Department }\end{array}$




$\begin{array}{ll}\text { PCE } & \text { tetrachlororethene } \\ \text { RCRA } & \text { Resource Conservation and Recovery Act } \\ \text { SMMO } & \text { soluble methane monooxygenase } \\ \text { SNL/NM } & \text { Sandia National Laboratories/ New Mexico } \\ \text { SWMU } & \text { Solid Waste Management Unit } \\ \text { TA-V } & \text { Technical Area-V } \\ \text { TCE } & \text { trichloroethene } \\ \text { T\&FRs } & \text { technical and functional requirements } \\ \text { VC } & \text { vinyl chloride } \\ \text { VOC } & \text { volatile organic compound }\end{array}$




\subsection{INTRODUCTION}

The Corrective Measures Evaluation Work Plan Technical Area-V Groundwater (SNL/NM 2004a), referred to in this report as the TA-V (Technical Area-V) CME (Corrective Measures Evaluation) Work Plan, was prepared as directed by the Compliance Order on Consent (COOC) issued by the New Mexico Environment Department (NMED) (NMED 2004). The TA-V CME Work Plan outlines a process to evaluate remedial alternatives to identify a corrective measure for the Sandia National Laboratories/New Mexico (SNL/NM) TA-V groundwater. As part of this process, an initial screening of technologies was conducted and the results were presented in the TA-V CME Work Plan. The technologies that passed the initial screening were used to identify nine remedial alternatives for TA-V. These nine remedial alternatives are:

1. Groundwater monitoring for volatile organic compounds (VOCs) and nitrate,

2. Monitored natural attenuation (MNA) for VOCs and nitrate,

3. MNA for VOCs and groundwater monitoring for nitrate,

4. In situ bioremediation (ISB) followed by MNA for VOCs and nitrate,

5. ISB followed by MNA for VOCs and groundwater monitoring for nitrate,

6. ISB followed by MNA for VOCs and MNA for nitrate,

7. Pump-and-treat followed by MNA for VOCs and nitrate,

8. Pump-and-treat followed by MNA for VOCs and groundwater monitoring for nitrate, and

9. Pump-and-treat followed by MNA for VOCs and MNA for nitrate.

Section 5.0 of the TA-V CME Work Plan, “Remedial Alternative Evaluation Plan,” provides guidance on activities to be used for evaluating the nine remedial alternatives (SNL/NM 2004a). The Remedial Alternative Evaluation Plan identifies data gathering activities to be carried out in four stages, as follows:

5. Paper study,

Formatted: Bullets and Numbering

6. Numerical modeling,

7. Laboratory studies, and

8. Field scale studies.

\subsection{CME Interim Documentation}

As the four stages of data gathering activities are carried out, individual informal reports will be created to document the results. These reports will be prepared by the CME implementation team to be reviewed by the project leader, technical peer review panel, and technical support personnel (project organizational structure is discussed in Section 7.2 of the TA-V CME Work Plan) (SNL/NM 2004a). The purpose of the informal reports includes: 
- Reporting results and interpretation of results to the project leader, technical peer review panel and technical support personnel,

- Documenting decisions made during the CME process and documenting the results of the three stages of data gathering, and

- Providing supporting information for the CME Report.

Figure 1-1 illustrates the staged process of data gathering activities and the subsequent reports.

\subsection{Organization}

The TA-V CME Work Plan presented objectives for a "paper study" to focus on the continuing assessment of available data and information on the alternative technologies being considered for use at TA-V. The primary objectives for this assessment include presentation of conceptual designs, completion of a technology data gap review, and providing recommendations for additional activities needed to fill these data gaps to support completion of the CME Report. This document, the Alternative Technology Data Gaps Review for Technical Area-V Groundwater, is organized such that each section addresses an objective of the paper study. The outcome of the process is a group of recommended data gathering activities. This data gap review document is organized into the following sections:

- Section 1. Introduction. This section includes a presentation of the remedial alternatives being considered, a description of the objectives of the Alternative Technology Data Gaps Review, and a summary of Current Conceptual Model of Groundwater Flow and Contaminant Transport at Sandia National Laboratories/New Mexico Technical Area-V referred to in this report as the TA-V Conceptual Model (SNL/NM 2004b). Also, included in this section is a presentation of additional site data compiled during the paper study.

- Section 2. Technology Descriptions. This section provides more detail about the four technologies that passed the initial screening than the descriptions provided in the TA-V CME Work Plan (SNL/NM 2004a). As additional technical details were compiled and calculated, it became apparent that several of the nine remedial alternatives no longer needed to be considered for data gathering activities. Section 2 includes details on why and how the list of nine remedial alternatives was reduced to six.

- Section 3. Remedial Alternative Conceptual Designs. This section presents the six remedial alternatives that are considered in the preliminary remedial alternative evaluation and provides a conceptual design, consisting of process diagrams, assumptions, and technical and functional requirements (T\&FRs) for each.

- Section 4. Preliminary Remedial Alternative Evaluation. This section presents the methods used for evaluating remedial alternatives and the results. The outcome of the evaluation is a list of remedial alternatives that will be considered in data gathering activities.

- Section 5. Recommendations for Further Studies. During the paper study, data gaps regarding individual remedial alternatives and application at TA-V have been identified. This section identifies field, laboratory, and numerical modeling studies that will provide the necessary information to choose a preferred remedy. 


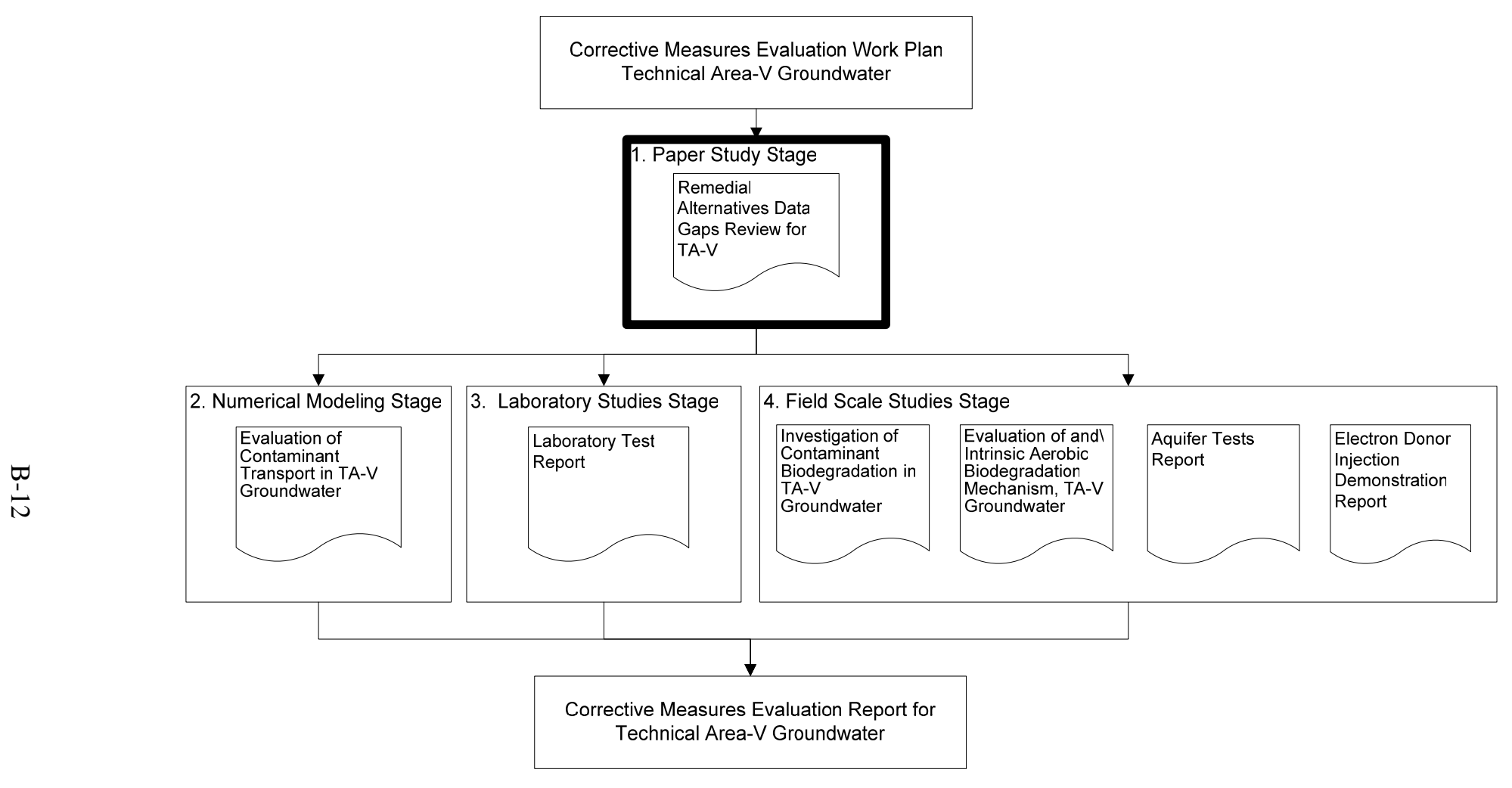

Figure 1-1. Illustration of the staged process of data gathering with potential activities and subsequent reports. 


\subsection{Site Conceptual Model Information}

In Section IV.C of the Draft Final COOC (NMED 2004), NMED requires a CME of SNL/NM TA-V groundwater contamination. Evaluation of remedial alternatives for COCs in groundwater at TA-V requires a current conceptual model of contaminant transport that will provide the basis for a technically defensible evaluation. The following summary includes information summarized from the Current Conceptual Model for TA-V (Sections 1.4.1 through 1.4.4) (SNL/NM 2004b). Section 1.4.5 summarizes the results of calculations performed during the paper study that are relevant to the conceptual designs and evaluation of remedial alternatives.

\subsubsection{Contaminant Releases}

Contaminants of concern in groundwater at TA-V consist of trichloroethene (TCE), tetrachloroethene (PCE), and nitrate. Key elements of the current conceptual model of contaminant transport at TA-V are shown in Figure 1-2. These elements consist of contaminant releases, contaminant transport in the vadose zone, and contaminant transport in groundwater

Local recharge at TA-V is attributed mainly to wastewater disposal to the Liquid Waste Disposal System (LWDS) drainfield (SWMU 5) (6.5 million gal during 1963-1967) and surface impoundments (SWMU 4) (12 million gal during 1967-1971), and to the TA-V seepage pits (SWMU 275) (30 to 50 million gal during the 1960s to 1992). After 1992, wastewater was disposed to the City of Albuquerque (COA) sewage system. There is no ongoing recharge from wastewater disposal. Contaminants in wastewater included VOCs and nitrate.

\subsubsection{Volatile Organic Compounds}

TCE was present in water that was disposed to the LWDS drainfield during 1963-1967 and to the TA-V seepage pits from the 1960s until the early 1980s when TCE disposals were eliminated. Wastewater disposal to the seepage pits continued until 1992 and is no longer a source of contaminants to the subsurface. Based on the distribution of contaminants in groundwater, the drainfield and seepage pits were the two probable sources of organic contaminants in the aquifer at TA-V. Disposal of VOCs to the surface impoundments may have increased volatization of those compounds in the open air. Evaporative losses also were enhanced through surface disposal, which may have decreased the recharge from infiltrating impoundment water.

Low TCE concentrations in soil-gas samples collected from sediments beneath the release areas indicated that a secondary source of TCE does not exist within the vadose zone. No excess soil moisture is present in the vadose zone. Water and contaminants moved rapidly through the vadose zone during the seepage pit and LWDS disposals, and vadose zone drainage occurred soon after cessation of wastewater disposal. Because of increased environmental awareness, solvent disposals were eliminated in the early 1980s but wastewater disposal to the seepage pits continued. These continued disposals probably flushed contaminants that may have been present in the vadose zone into the aquifer. No additional vadose zone sampling is required. 


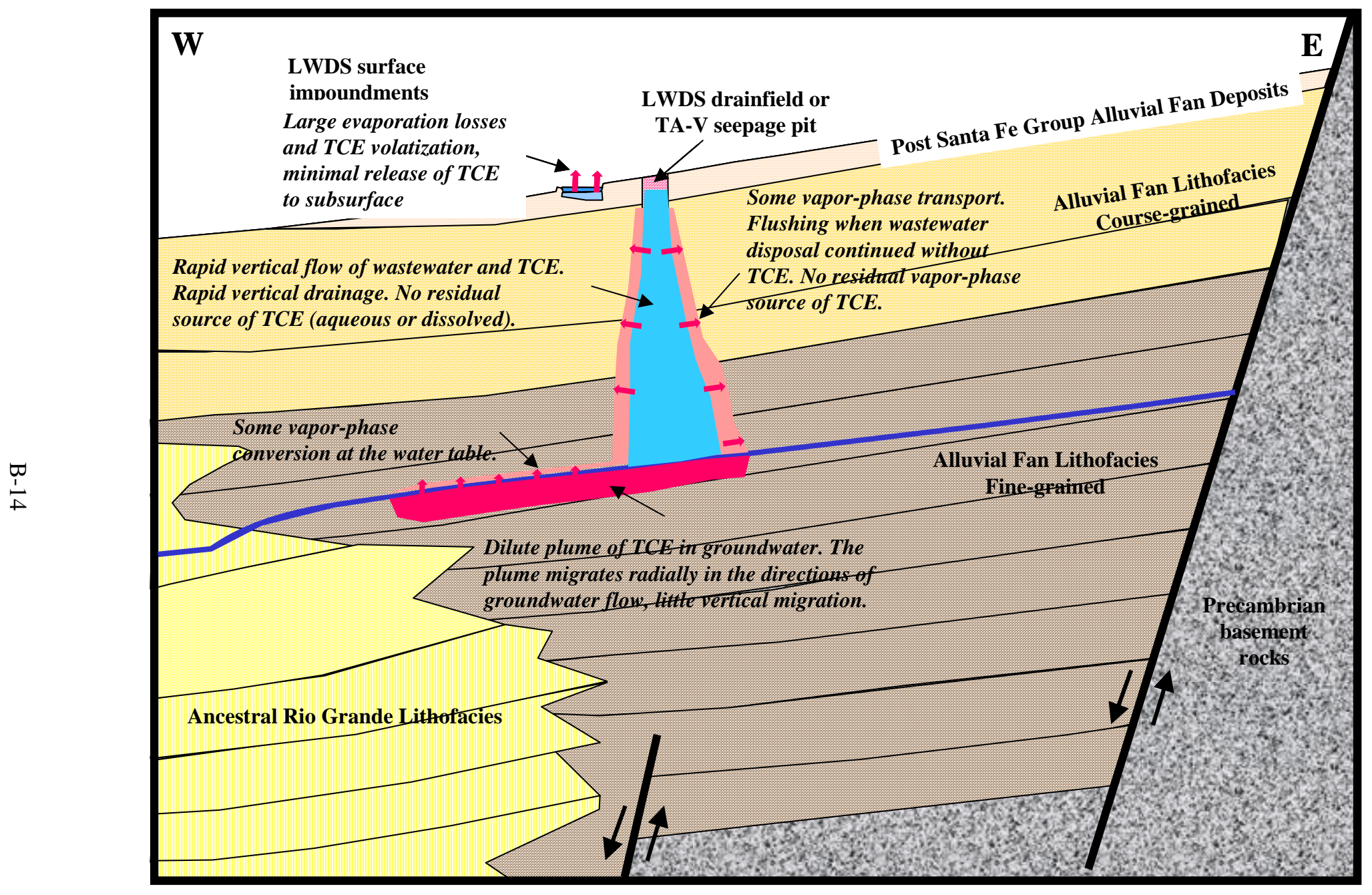

Figure 1-2. Key elements of the current conceptual model of contaminant transport at SNL/NM TA-V. 


\subsubsection{Nitrate}

Sanitary wastewater disposed to the TA-V seepage pits and to other septic systems contained nitrate. Nitrate releases continued until 1992 when the disposals to these septic systems were transferred to the COA sanitary wastewater disposal system.

Nitrate is considered to be a conservative constituent with regard to transport because it is highly soluble in water, is not typically sorbed by sediments, and is not biotransformed under aerobic conditions. As nitrate rapidly moved through the vadose zone with wastewater, no residual source was accumulated and no secondary nitrate releases have occurred.

\subsubsection{Contaminant Transport through the Vadose Zone}

The vadose zone at TA-V, consisting of approximately $500 \mathrm{ft}$ of unconsolidated to semi-consolidated alluvial sediments, forms the contaminant pathway by which contaminants migrated from shallow sources to the Santa Fe Group aquifer. Upper sections of the alluvial-fan sediments are relatively coarse-grained, becoming fine-grained and clay-rich with depth. The unsaturated and saturated hydraulic properties of the vadose zone at TA-V have not been characterized. However, they probably are highly variable and anisotropic because of the heterogeneous textures, lenticularity, layering, and changes in cementation.

\subsubsection{Flow in the Vadose Zone}

Infiltration of wastewater from the LWDS drainfield and the TA-V seepage pits resulted in the development of preferential pathways of saturated or partially saturated flow through the thick vadose zone to the aquifer. Disposal to the surface impoundments did not result in a significant contribution of wastewater and contaminants to the vadose zone or aquifer due to evaporative losses and volatization of VOCs in the open air during surface disposal. Other sources of recharge (i.e., precipitation or streamflow) do not constitute a significant source of water in the vadose zone at TA-V.

Infiltrating wastewater from the LWDS drainfield and the TA-V seepage pits flowed rapidly downward through the discontinuous, layered, lenticular sediments in the vadose zone. Discharge of wastewater to the LWDS drainfield was discontinued in 1967; discharge to the TA-V seepage pits was discontinued in 1992. Based on the moisture content measurements in vadose-zone sediment samples, drainage of excess water from the vadose zone to the aquifer was rapid after discharge ceased. Insignificant moisture from wastewater discharged at TA-V remains in the vadose zone.

\subsubsection{Transport of Volatile Organic Compounds through the Vadose Zone}

Past mechanisms of contaminant transport from TA-V sources through the vadose zone included rapid dissolved-phase transport in wastewater and a potentially slight contribution from subsurface vapor-phase transport. No transport of contaminants presently exists from the vadose zone to groundwater. 
Subsurface data collected during TA-V drilling activities indicate that water and contaminants from disposal facilities moved rapidly through the vadose zone during the seepage pit and LWDS disposals, and vadose-zone drainage occurred soon after cessation of wastewater disposal. TCE was not detected in most vapor samples collected from the vadose zone beneath the release areas. No excess soil moisture is present in the vadose zone.

Solvent disposals were eliminated at TA-V in the early 1980s, but wastewater disposal to the seepage pits continued. Continued disposals flushed contaminants that may have been present in the vapor phase or aqueous phase into the aquifer. No additional site investigations are required to characterize contaminant distribution and transport through the vadose zone.

\subsubsection{Transport of Nitrate through the Vadose Zone}

Nitrate moved conservatively and rapidly with disposed wastewater through the vadose zone to the aquifer. Transport of nitrate ceased in 1992 when septic system disposals were discontinued. Because of the conservative transport characteristics and high solubility of nitrate, no secondary source of nitrate exists within the vadose zone from wastewater disposals.

\subsubsection{Contaminant Distribution in Groundwater}

Flow in the Santa Fe Group aquifer at TA-V is the only mechanism for potential contaminant transport to downgradient receptors. Subsequent sections summarize key elements of groundwater flow, distribution of VOCs and nitrate in groundwater, and the adequacy of the monitoring network to evaluate the transport of contaminants.

\subsubsection{Groundwater Flow}

Hydrostratigraphic units of significance in the vicinity of SNL/NM TA-V are identified as the alluvial fan lithofacies and ancestral Rio Grande (ARG) lithofacies of the Santa Fe Group. The Santa Fe Group aquifer underlying TA-V consists of fine-grained, clay-rich sediments of the alluvial fan lithofacies. These units interfinger to the west with coarser fluvial sediments of the ARG. Saturated thickness in the vicinity of TA-V may range from less than $100 \mathrm{ft}$ to several thousand feet across faults.

Horizontal hydraulic conductivity of saturated sedimentary units at TA-V ranges from $10^{-5}$ to $10^{-2} \mathrm{ft} / \mathrm{min}$. Vertical hydraulic conductivity at TA-V ranges from $10^{-3}$ to $10^{-4} \mathrm{ft} / \mathrm{min}$. Laboratory and field measurements of total porosity measurements range from 0.24 to 0.43 . Within the context of velocity calculations, an assumed effective porosity of 0.25 is considered to be a conservative estimate. The clay-rich sediments that comprise the Santa Fe Group aquifer at TA-V are characterized by small well yields, ranging from less than 1 to more than 20 gallons per minute (gpm) with drawdowns exceeding $10 \mathrm{ft}$.

The subregional potentiometric surface map for February through April 2000 indicates that groundwater flow in the vicinity of TA-V is generally to the west. Groundwater flow to the west of TA-V turns sharply to the north moving toward COA pumping centers located north of Kirtland Air Force Base (KAFB). The sharp change in flow direction coincides with the location of coarse, well-sorted ARG sediments. These sediments are much more permeable than the fine-grained sediments of the alluvial fan facies at TA-V and permit more rapid groundwater flow. Model-estimated time of travel from the area directly south of TA-V to the production wells exceeds 100 years (SNL/NM 2001). 
The 2003 potentiometric surface map for TA-V shows a subtle groundwater mound that is centered in the northern part of TA-V and illustrates that groundwater flow occurs radially to the west, northwest, and south. Based on the absence of any source of local recharge, the groundwater mound at TA-V is considered to be an artifact of the regional water-level decline within the heterogeneous aquifer. At TA-V, the water table slopes approximately $14 \mathrm{ft} / \mathrm{mile}$ for a horizontal hydraulic gradient of about 0.003 .

Water levels at TA-V have declined steadily, averaging $0.7 \mathrm{ft} / \mathrm{yr}$ during 1993 through 2000. These declines are characteristic of long-term regional water-level declines resulting from municipal pumpage to the north. Seasonal variations in water levels are attributed to changes in municipal water usage from summer to winter. No short-term water-level changes resulting from local recharge or pumpage effects are evident.

Calculated horizontal flow velocities range from 0.5 to $168 \mathrm{ft} / \mathrm{yr}\left(10^{-6}\right.$ to $\left.10^{-4} \mathrm{ft} / \mathrm{min}\right)$. The lower velocities are typical of clays and higher velocities are typical of medium to fine-grained sand. Calculated vertical flow velocities range from 11.2 to $111 \mathrm{ft} / \mathrm{yr}\left(10^{-5}\right.$ to $\left.10^{-4} \mathrm{ft} / \mathrm{min}\right)$.

\subsubsection{Distribution of Volatile Organic Compound Contaminants of Concern in Groundwater at TA-V}

TCE and PCE are contaminants of concern in groundwater at TA-V because they have been detected above maximum contaminant levels (MCLs). TCE has been detected above the MCL in three wells. PCE was detected at or slightly above the MCL in three water samples from one well.

The center of TCE mass in TA-V groundwater has migrated approximately $300 \mathrm{ft}$ northwest from the drainfield contaminant release area in the 36 years since disposal was terminated in 1967. Based on this lateral movement, TCE has migrated approximately $8 \mathrm{ft} / \mathrm{yr}$, which is within the calculated range of groundwater flow velocity of 0.5 to $168 \mathrm{ft} / \mathrm{yr}$. The expansion of a lobe of the TCE plume to the south may represent additional input of TCE through the TA-V seepage pits and subsequent dilution as wastewater disposal continued after cessation of TCE disposals in the early 1980s. TCE migration to the northwest and south from TA-V sources is consistent with radial groundwater flow away from the subtle mound at TA-V attributed to residuals from regional water-level declines.

PCE concentrations were at or near the MCL in three samples from one well. They since have decreased to below the MCL in that well. PCE concentrations in other TA-V wells generally were less than the method detection limit. Although PCE was determined to be a COC based on those three samples, PCE is not a major groundwater contaminant at TA-V based on the low concentrations and limited distribution. However, groundwater sampling for PCE will continue.

The COA municipal wells and KAFB supply wells have been identified as the only potential downgradient receptors of contaminants from TA-V. Contaminant travel times are in excess of 100 years. The potential TCE concentrations in groundwater along flow paths to these downgradient receptors are unknown. Additional numerical modeling studies will provide an 
understanding of TCE concentration changes along flowpaths. This understanding will assist in evaluation of remediation technologies.

The proposed Mesa del Sol well field, approximately 3 miles west of TA-V, is located on the western side of the north-trending groundwater trough. This proposed well field would only become a downgradient receptor of contamination from TA-V in the unlikely event that COA pumping centers were discontinued and groundwater flow systems reverted to the west and southwest. The effect of this scenario on potential contaminant concentrations at these downgradient receptors is unknown.

Geochemical conditions in groundwater at TA-V are sufficiently known to begin technology evaluations. Dissolved oxygen concentrations in groundwater indicate that aerobic conditions exist within the aquifer. Major ion analyses demonstrate that geochemical conditions are stable. The presence of increased concentrations of dissolved chloride are indicative of disposal of wastewater with elevated chloride concentrations and do not represent dechlorination products from contaminant degradation. The presence of very low concentrations of total organic carbon in groundwater indicates that little carbon is available as an electron donor for natural biodegradation.

\subsubsection{Distribution of Nitrate in Groundwater at TA-V}

Nitrate is an inorganic contaminant of concern at TA-V. Nitrate was detected above the MCL in four wells in the vicinity of TA-V, including two wells within the TCE plume and two wells (AVN wells) east of TA-V. Nitrate concentrations in groundwater within the TCE plume at TA-V are considered to be derived from disposals of sanitary wastes to the TA-V septic systems.

The AVN wells are hydraulically upgradient of TA-V septic-system nitrate releases. Nitrate concentrations above the MCL in the AVN wells could not have been derived from those releases. These concentrations indicate that the principal source of nitrate may be present upgradient and to the northeast of TA-V. The upgradient source may be derived from the incremental contribution of nitrate from upgradient sites that emulate a non-point source. Another potential contributor may be from sub-regional natural enrichment of nitrate in soils or groundwater-bearing sediments. A third potential contributor may be from an unidentified anthropogenic nitrate source. Evaluation and investigation of this upgradient source is beyond the scope of TA-V remedial activities.

\subsubsection{Adequacy of the Monitoring Network to Evaluate the Distribution of Contaminants}

The groundwater monitoring network at TA-V consists of upgradient, background wells to characterize the chemical quality of groundwater moving into the TA-V area, performance wells that define the present distribution of contaminants at TA-V, and downgradient sentry wells to evaluate future contaminant migration. Assessment of the configuration of existing monitoring wells at TA-V (Figure 1-3) indicates that the network is sufficient to adequately characterize the distribution of contaminants at TA-V. The screen intervals of nine TA-V monitoring wells are at or near the water table. Three well pairs provide vertical monitoring capability and are located in areas proximal to known releases. No additional wells are required. 
This Page Intentionally Left Blank

B-19 


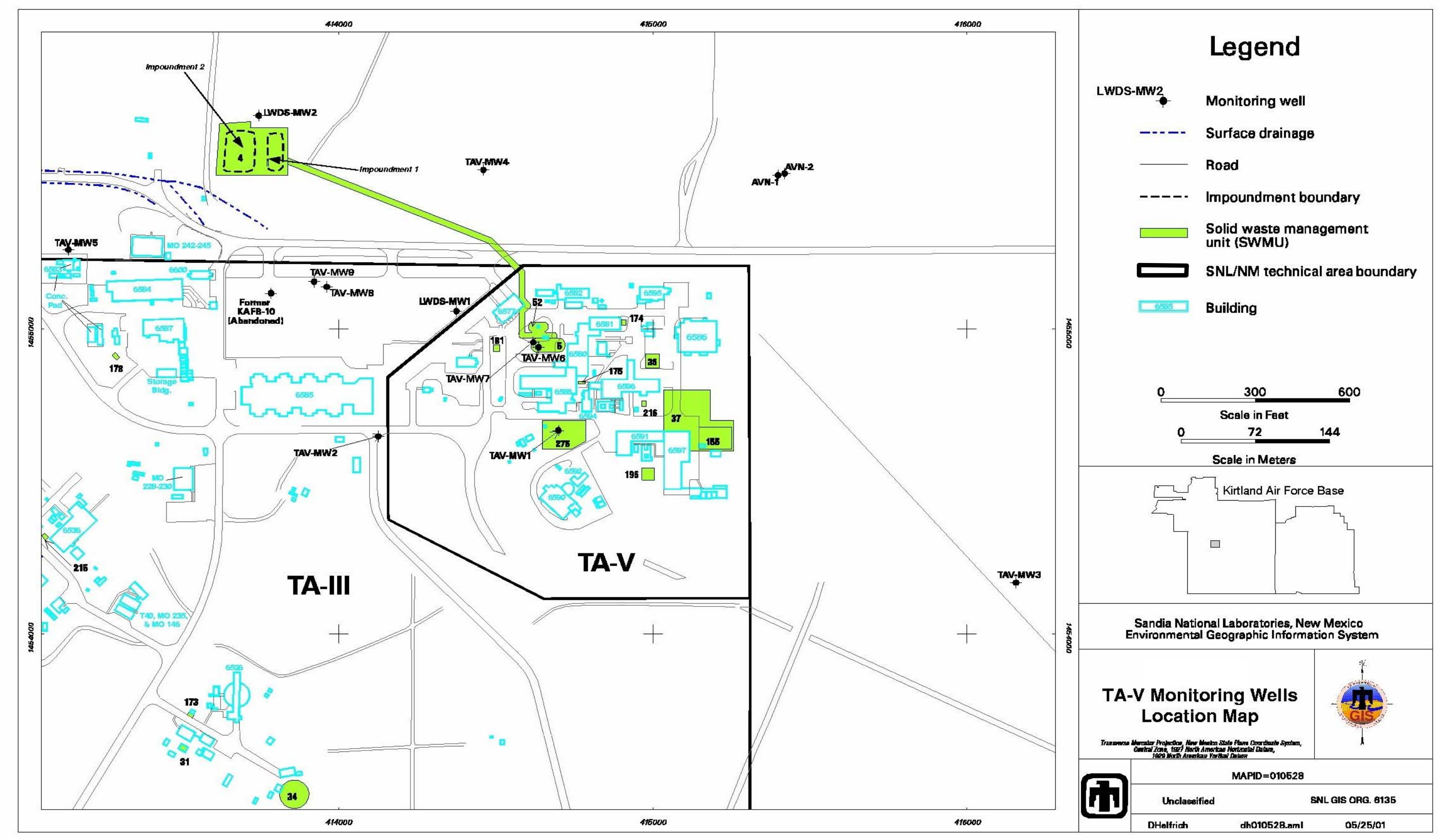

Figure 1-3. Location of groundwater monitoring wells in the vicinity of SNL/NM TA-V. 
This Page Intentionally Left Blank 


\subsubsection{Information Compiled during the Paper Study}

During the paper study, parameters were estimated that are relevant to the conceptual model for TA-V. The parameters are an estimation of the specific capacity of a new well, an updated estimate of the range of contaminant transport velocities, and an estimate of the useful life of the monitoring well network. Estimations of specific capacity and contaminant transport are presented in Appendix A, and were used as inputs for calculations performed during the paper study. Estimates of the specific capacity of individual wells in the TA-V monitoring well network ranged from 0.03 to $0.86 \mathrm{gpm} / \mathrm{ft}$ of drawdown. This range was used to represent a hypothetical extraction or injection well during the paper study. Also, a revised estimate of contaminant transport velocity based on estimates of first arrival of contaminants in a monitoring well was $20 \mathrm{ft} / \mathrm{yr}$. For evaluation purposes transport velocity was assumed to range from $8 \mathrm{ft}$ per year (SNL/NM 2004b) to $20 \mathrm{ft}$ per year (Appendix A).

Although no additional wells are required to monitor contaminants in TA-V groundwater at the current time (Section 1.4.4), the predicted useful life of many of these wells is shorter than the projected duration of some remedial alternatives due to regional water-level declines. Water levels at TA-V have been declining at an average rate of $0.7 \mathrm{ft} / \mathrm{yr}$ during 1993-2000 (Figure 1-4). The projected depths of the saturated thickness in TA-V monitoring wells is shown in Table 1-1. These projected depths are based on an average water-level decline of $0.7 \mathrm{ft} / \mathrm{yr}$ and are presented through the year 2036. The end of the effective well life is represented with a depth of $0 \mathrm{ft}$ (shaded boxes). As demonstrated in Table 1-1, groundwater monitoring will not be possible in six of the existing monitoring wells by 2036. Therefore, consideration will need to be given to replacing these wells in the future if a long-term monitoring remedy is implemented.

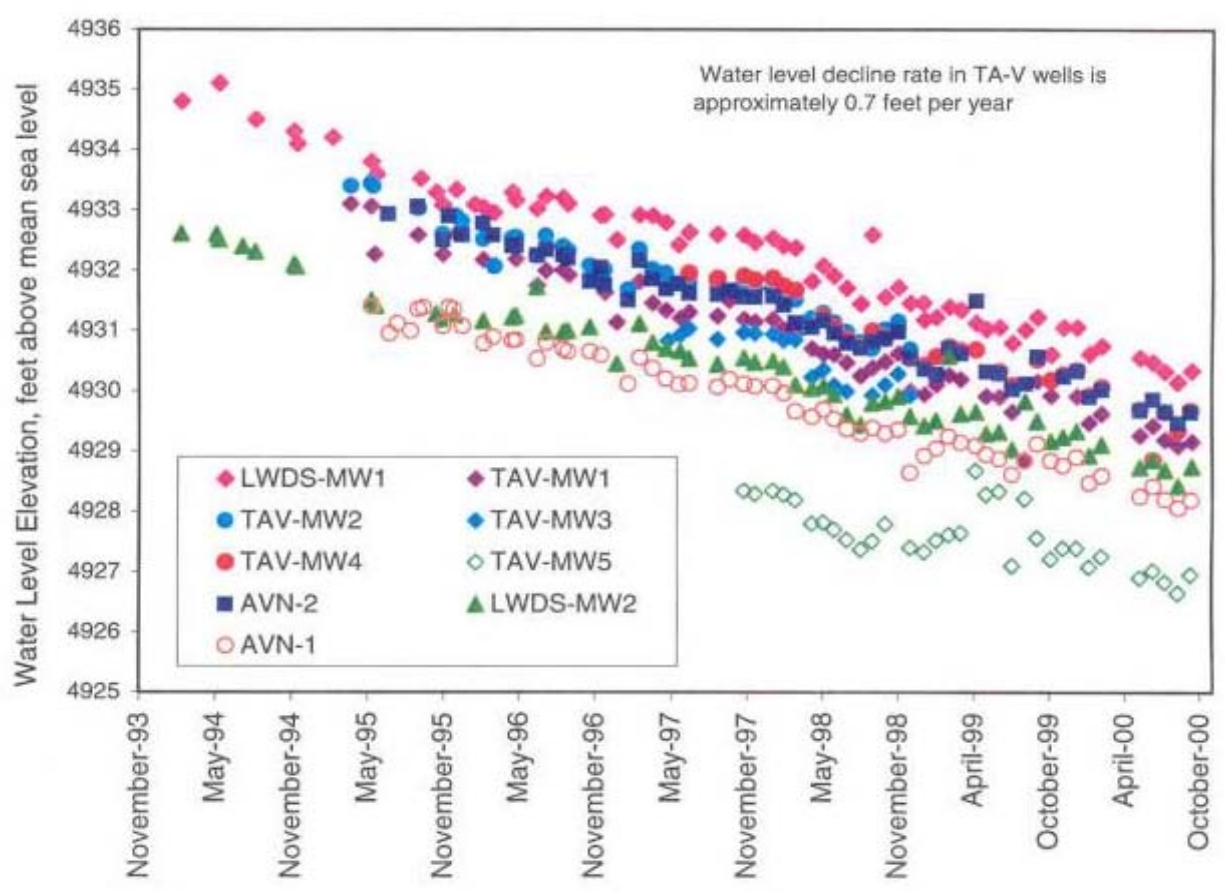

Figure 1-4. Water level measurements in TA-V wells during 1993-2000 (SNL/NM 2004b).

B-22 
Table 1-1. Predicted depth (ft) of the saturated thickness in TA-V monitoring wells by year.

\begin{tabular}{|c|c|c|c|c|c|}
\hline Monitoring Well Name ${ }^{1}$ & 2003 & 2005 & 2010 & 2020 & 2036 \\
\hline \multicolumn{6}{|c|}{ Background Wells (Upgradient) } \\
\hline TAV-MW3 & 16 & 15 & 11 & 4 & 0 \\
\hline $\mathrm{AVN}-1$ & 75 & 73 & 70 & 63 & 52 \\
\hline AVN-2 & 2 & 1 & 0 & 0 & 0 \\
\hline \multicolumn{6}{|c|}{ Performance Wells (Near Contaminant Sources) } \\
\hline TAV-MW1 & 1 & 0 & 0 & 0 & 0 \\
\hline TAV-MW6 & 25 & 24 & 21 & 14 & 2 \\
\hline TAV-MW7 & 113 & 112 & 108 & 101 & 90 \\
\hline LWDS-MW1 & 22 & 20 & 17 & 10 & 0 \\
\hline TAV-MW8 & 24 & 23 & 19 & 12 & 1 \\
\hline TAV-MW9 & 112 & 110 & 107 & 100 & 89 \\
\hline TAV-MW2 & 20 & 19 & 15 & 8 & 0 \\
\hline TAV-MW4 & 17 & 16 & 12 & 5 & 0 \\
\hline \multicolumn{6}{|c|}{ Sentry Wells (Downgradient) } \\
\hline TAV-MW5 & 26 & 25 & 21 & 14 & 3 \\
\hline LWDS-MW2 & 43 & 41 & 38 & 31 & 20 \\
\hline
\end{tabular}

1: Predicted saturated thickness in each well is based on a projection of the average rate of water level decline at $\mathrm{TA}-\mathrm{V}$ of $0.7 \mathrm{ft} / \mathrm{yr}$ The end of well life is represented with a depth of $0 \mathrm{ft}$ (shaded boxes). 


\subsection{TECHNOLOGY DESCRIPTIONS}

Four technologies are applied in various combinations to create the nine remedial alternatives presented in the TA-V CME Work Plan (SNL/NM 2004a). These technologies include:

- Groundwater monitoring,

- MNA,

- ISB, and

- Pump and treat.

The purpose of this section is to provide details about each technology, including considerations for evaluation and implementation at TA-V. This information is compiled from a review of the current literature, professional experience, and from calculations performed during the paper study (Appendices B, C, and D).

This analysis has resulted in redefining the remedial alternatives that are evaluated. As additional technical details were compiled and calculated, it became apparent that several of the nine remedial alternatives no longer needed to be considered. Therefore, this section includes details on how and why this was done; a revised list of remedial alternatives is presented in Section 2.5 .

\subsection{Technical Description of Groundwater Monitoring}

Implementation of groundwater monitoring consists of monitoring contaminants of concern (COCs). This technical approach is applied as a stand-alone remedial alternative and may be applied as part of other remedial alternatives.

\subsubsection{Considerations for Evaluation of Groundwater Monitoring}

Advantages of groundwater monitoring, relative to more active remediation technologies, include a small secondary waste stream, contaminants are not brought to the surface, and no construction of treatment facilities. The monitoring well network would be maintained and consideration must be given to replacing monitoring wells due to declining water levels.

\subsubsection{Implementation of Groundwater Monitoring at TA-V}

The conceptual design for implementing a groundwater monitoring technology includes a description of the monitoring well network and a preliminary design of the monitoring strategy. It is assumed that implementation of groundwater monitoring as a long-term corrective action would include two operational phases: performance operations and long-term operations (Table 2-1). Performance operations include annual sampling and reporting during a period when performance is monitored and a long-term strategy is devised. Long-term operations include annually monitoring of these wells with an annual data review and a reporting requirement every 5 years. Remedy implementation would continue until compliance objectives are met. 
Table 2-1. Groundwater monitoring operational phases.

\begin{tabular}{lccc}
\hline \multicolumn{1}{c}{ Operational Phase } & Monitoring Frequency & Reporting Frequency & Timeframe \\
\hline Performance Operations & Annual & Annual & TBD \\
Long-term Operations & Annual & 5 Years & TBD \\
\hline TBD $=$ to be determined & & & \\
\hline
\end{tabular}

\subsection{Technical Description of Monitored Natural Attenuation}

MNA is the reliance on natural attenuation processes to achieve site-specific remedial objectives within a reasonable timeframe (DOE 1999). For the TA-V remedial alternative evaluation, MNA is applied as a stand-alone remedial alternative and is also applied as part of other remedial alternatives. Sections 2.2.1 and 2.2.2 describe considerations for evaluation and implementation of MNA.

\subsubsection{Considerations for Evaluation of MNA}

Guidance for determining favorable conditions for MNA comes from:

- Use of MNA at Superfund, RCRA Corrective Action, and Underground Storage Tank Sites (EPA 1999), and

- Decision-Making Framework Guide for the Evaluation and Selection of Monitored Natural Attenuation Remedies at Department of Energy Sites (DOE 1999).

Source control technologies are to be used to control an active source term, which has been defined as a source inventory of contaminant that is being released to the groundwater where the rate of contaminant release is greater than attenuation rates such that the inventory of mobile contaminants is increasing over time (DOE 1999). One important conclusion of TA-V Conceptual Model is that because there is no remaining source, source control measures will not be a necessary component of a remedy at TA-V.

Figure 2-1 is a decision framework for implementing MNA (DOE 1999). The first tier of decision-making includes two options: (1) the contamination currently does not pose an unacceptable risk, there is no active source term, and plume contours are static or retreating or (2) data suggest attenuation mechanisms are operable or exist. Given these criteria and site-specific information, MNA can be a viable remedial alternative or portion of a remedial alternative at TA-V and any remedy involving MNA will be compared to the second and third tier criteria as the CME progresses. The applicability of MNA to meet clean-up goals in a reasonable timeframe is evaluated as part of the paper study and the ongoing remedial alternative evaluation process. 


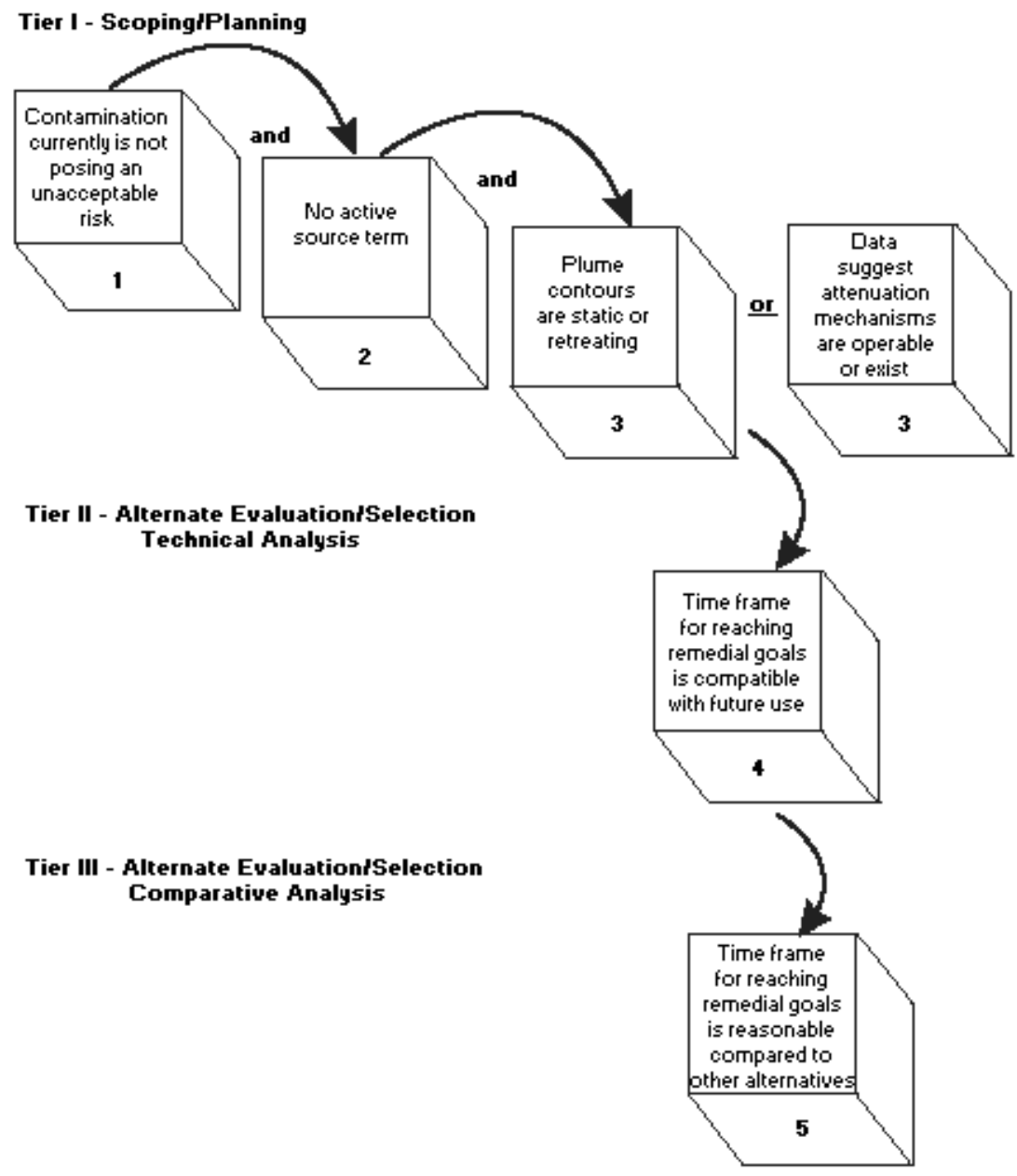

Figure 2-1. Decision framework for evaluating MNA (from DOE 1999).

\subsubsection{Implementation of MNA at TA-V}

Implementation of MNA would allow for intrinsic attenuation of COCs in the subsurface. Implementation of MNA as a stand-alone remedial alternative would occur in two phases: (1) the performance operations phase and (2) the long-term operations phase (Table 2-2). The timeframe of these phases would be determined based on the capability to demonstrate that the remedial alternative will meet clean-up goals. Prior to MNA implementation, characterization activities would be performed to determine whether intrinsic contaminant attenuation is taking place in the subsurface and to determine an appropriate monitoring strategy. Numerical groundwater models would be used to predict contaminant transport and the effects of dispersion on the contaminants. 
Table 2-2. MNA operational phases.

\begin{tabular}{c|c|c|c}
\hline \multicolumn{1}{c|}{ Operational Phase } & Monitoring Frequency & Reporting Frequency & Timeframe \\
\hline Performance Operations & Annually & Annual & TBD \\
\hline Long-Term Operations & Annually & 5 Years & TBD \\
\hline
\end{tabular}

$\mathrm{TBD}=$ to be determined

Monitoring is a key component of any MNA remedial alternative. Monitoring would begin during performance operations with the purpose of confirming natural attenuation processes and would continue through long-term operations to track the progress of MNA. The monitoring strategy would include clearly defined sampling frequency utilizing the current monitoring well network summarized in Section 2. A preliminary sampling frequency is summarized in Table 2-2. Regional water-level declines would be considered when determining the useful life of the existing monitoring well network. Analytes would include COCs and possibly other parameters to assess MNA performance.

\subsubsection{Natural Attenuation Mechanisms}

Natural attenuation mechanisms may include degradation, volatilization, sorption, and dispersion. Dispersion is an attenuation mechanism for nitrate, although under certain conditions degradation of nitrate may also occur. PCE in TA-V groundwater would naturally attenuate or be reduced to below MCLs through sorption, dispersion, and volatilization. Recent groundwater monitoring demonstrates that PCE concentrations are below MCLs (SNL/NM 2004b). TCE is susceptible to attenuation through the mechanisms of sorption, dispersion, volatilization, and degradation through natural biological processes (biodegradation). Biodegradation mechanisms may include aerobic and anaerobic processes, including aerobic cometabolism and anaerobic reductive dechlorination (ARD).

Cometabolism is defined as the transformation of an organic compound by a microorganism that is unable to use the substrate as a source of energy or as one of its constituent elements (Alexander 1967). Cometabolism, as the name implies, occurs in conjunction with the metabolism of another substrate, which the microorganisms use for carbon and/or energy. Thus, aerobic cometabolism requires the presence of the primary substrate and the cometabolic substrate. The primary substrate is required because the same enzyme that transforms the primary substrate also fortuitously transforms the cometabolic substrate. If the primary substrate is absent, the enzyme required for cometabolic transformation would not be induced and the cometabolic transformation would not occur. It is more likely that aerobic processes of degradation are occurring at TA-V rather than anaerobic considering the dissolved oxygen concentrations throughout the plume. Degradation half-life estimates of aerobic cometabolism at another deep aquifer site ranged from 12 to 15 years (DOE-ID 2003) and degradation rates at TA-V may be similar. 
TCE, cis-1,2-dichloroethene (cis-DCE), trans-1,2-dichloroethene (trans-DCE), and vinyl chloride (VC) have all been shown to be susceptible to cometabolic oxidation under aerobic conditions (e.g., Wilson and Wilson 1985; Semprini et. al. 1990). In addition, cis-DCE, trans-DCE, 1,1-dichloroethene, and VC have been shown to be susceptible to direct oxidation under both aerobic (Vogel, Criddle, and McCarty 1987; Bradley and Chapelle 2000; Klier et al. 1999; Coleman et al. 2002) and anoxic conditions (Bradley and Chapelle 1998). PCE has been shown to be resistant to both direct and cometabolic oxidation (McCarty 1996). Several primary substrates induce aerobic cometabolism of chlorinated ethenes. Among them are methane, propane, butane, phenol, toluene, and ammonia. The enzyme methane monooxygenase (MMO), present in methanotrophs, is known to cometabolize TCE. One form of MMO, soluble MMO (sMMO), has been shown to catalyze rapid oxidation of chlorinated ethenes on the order of minutes to hours (e.g., Oldenhuis et. al. 1989; Aziz et. al. 1999).

Evidence presented in the Current Conceptual Model for TA-V (SNL/NM 2004b) suggests that, although the process of ARD may have occurred during or shortly after disposal of wastes, this process is likely no longer occurring because the groundwater is now aerobic. Anaerobic biodegradation processes may include denitrification and ARD. Both processes are mechanisms through which indigenous microorganisms facilitate the degradation of contaminants to innocuous products. In zero-oxygen environments, microorganisms carry out respiration through reactions utilizing chemicals other than oxygen as terminal electron acceptors. Electron acceptors typically include nitrate, oxidized metals, sulfate, and carbon dioxide (Figure 2-2). Under strictly anaerobic conditions, PCE and TCE have been shown to be subject to microbial degradation under conditions where these compounds serve as a growth-linked electron acceptor. Denitrification is the process by which nitrate is utilized as a growth-linked electron acceptor.

\subsection{Technical Description of In Situ Bioremediation}

ISB is implemented by adding degradable organic carbon and/or nutrients to the aquifer. Indigenous microorganisms then increase in population and utilize available electron acceptors as they degrade organic carbon. The free energy yielded by redox reactions varies substantially depending upon the electron acceptor, as shown in Figure 2-2. During respiration, microorganisms preferentially utilize the electron acceptors yielding the greatest free energy. Figure 2-2 shows that the order of preference for the most common inorganic electron acceptors is oxygen, nitrate, manganese (IV), iron (III), sulfate, and carbon dioxide. Therefore, the dominant microbial community in a groundwater system is largely dependent upon the distribution of electron acceptors. Where oxygen is plentiful, aerobic bacteria will predominate; where oxygen is depleted but nitrate is plentiful, nitrate-reducing bacteria will predominate; and so on. Once highly reducing conditions are created (i.e., methanogenic), ARD becomes energetically favorable and complete dechlorination of chloroethenes to ethene is facilitated if dechlorinating microorganisms are present in sufficient number.

The presence of cis-DCE at TA-V indicates that limited biodegradation of PCE and TCE occurred historically before the system became carbon limited. The current aerobic conditions in the contaminant plume indicate that ARD has ceased. In order to create reducing conditions at TA-V that are conducive to ARD (methanogenic) and complete dechlorination of chloroethenes to ethane, denitrification of nitrate to nitrogen gas $\left(\mathrm{N}_{2}\right)$ must first occur (Figure 2-2). Also, it should be noted that if all of the TCE in the treatment cell is converted to cis-DCE, the resulting cis-DCE concentration will be below the MCL of $70 \mu \mathrm{g} / \mathrm{L}$. 


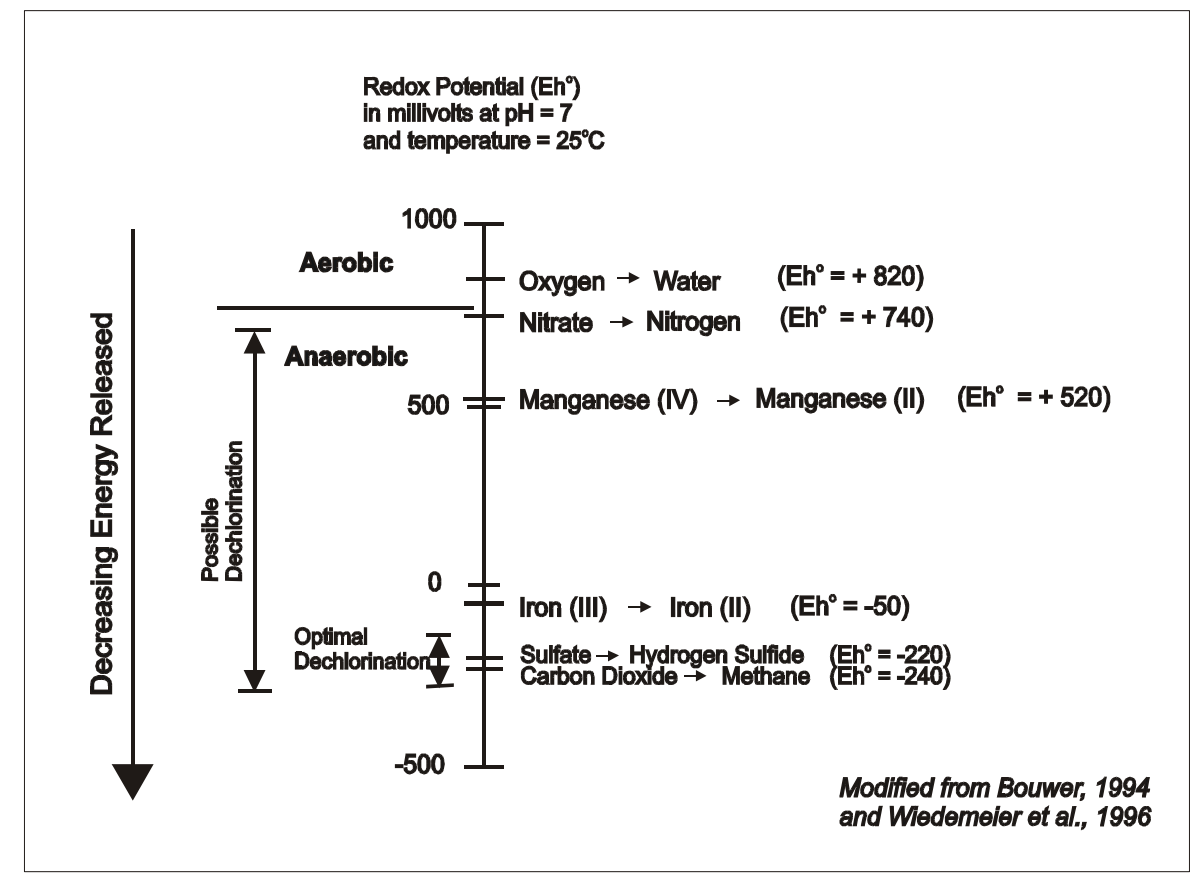

Figure 2-2. Energy available from typical microbially mediated redox reactions, and their relationship to reductive dechlorination.

ISB is applicable to both VOCs and nitrate at TA-V and has been identified for use in three of the nine proposed remedial alternatives. During the paper study, it has become evident that only one strategy for implementation of ISB at TA-V is practical. The remedial alternatives ISB followed by MNA for VOCs and groundwater monitoring for nitrate and ISB followed by MNA for VOCs and MNA for nitrate, define remedial alternatives that implement ISB for VOCs but not for nitrate. This implementation strategy would be possible if the contaminants were located in different areas. However, the location of nitrate contamination resulting from TA-V operations is believed to be within the same area as the TCE contamination (SNL/NM 2004b). Addition of electron donor would affect both contaminants. In order for dechlorination to occur, denitrification must first occur because nitrate is a competing electron acceptor that is more thermodynamically favorable than TCE or cis-DCE (see Figure 2-2). It is not possible to apply ISB to VOCs without reducing nitrate concentrations to levels that would be below clean-up goals. Therefore, these remedial alternatives can be eliminated from further evaluation. In addition, because nitrate would be reduced below MCLs by ISB, an MNA application to nitrate would not be necessary.

The only practical application of ISB at TA-V includes application of ISB to reduce VOCs in a high concentration zone and application of MNA to VOCs to further reduce VOC concentrations to below MCLs. This strategy would also reduce nitrate concentrations in groundwater to below MCLs. This single ISB remedial alternative will be referred to as ISB and MNA for VOCs and ISB for nitrate. 


\subsubsection{Considerations for Evaluation of ISB}

Site-specific characteristics need to be considered when evaluating ISB at TA-V. First, there is no active source and no secondary source in the vadose zone or in groundwater (SNL/NM 2004b). Second, declining water levels in the TA-V aquifer would reduce the useful life of the current monitoring well network. Implementation of ISB is expected to reduce contaminant concentrations to below MCLs within the lifetime of most of the present wells at TA-V, eliminating the need to replace these groundwater monitoring wells. Third, aquifer characteristics would limit distribution of amendments in the subsurface. If a new injection well has properties in the lower range for specific capacity and hydraulic conductivity, as summarized in Appendix A, this could make distribution of electron donor by injection into one to three wells infeasible. To increase distribution, either many injection wells or hydraulic fracturing will be required.

\subsubsection{Implementation of ISB Technology at TA-V}

Three options have been considered for implementation of ISB technology at TA-V. These options, along with implementation requirements for each, include:

1. Injection of an Aqueous Electron Donor-Requires drilling injection well(s) and injecting an aqueous phase electron donor (i.e., sodium lactate) with a sufficient volume of water to distribute this electron donor to the contaminated aquifer volume. Injection well locations may be near LWDS-MW1 or upgradient of wells TAV-MW8 and TAV-MW9. Effective distribution of electron donor is likely the most significant challenge of this approach and may require injection of large volumes of electron donor over a long period of time.

2. Hydraulic Fracturing followed by Aqueous Electron Donor Injection-Requires drilling new injection well(s) and performing hydraulic fracturing in the well(s) to enhance permeability for subsequent aqueous electron donor injections. Hydraulic fracturing may be an effective way to increase the rate at which a well accepts injected electron donor solution. Hydraulic fracturing is a process whereby a fluid is pumped into a well at a rate and pressure high enough to overcome the in situ confining stress and the material strength of a formation (i.e., soil or rock), resulting in the formation of a fracture. This process has been used for decades to enhance oil and gas production rates in wells for which production would otherwise be uneconomical. Induced fractures provide permeable pathways that enable fluids to flow to the well at a greater rate than would otherwise be possible. In practice, a slurry mixture containing a proppant (sand) and a viscous fluid (guar gum and water mixture) is pumped under pressure into subsurface soils to create a fracture. During pumping, downhole pressures and flow rates are monitored against time via logging computers. After pumping, the sand holds the fracture open while an enzyme or chemical additive breaks down the viscous fluid. The fluid subsequently drains out of the fractures leaving only permeable sand behind in the induced fractures. 
3. Application of Bio-Frac ${ }^{\mathrm{TM}}$ Technology-Bio-Frac ${ }^{\mathrm{TM}}$ is specifically for geo-environmental applications whereby a bioamendment is co-injected into the subsurface during soil fracturing. "Bio-Fracing" is conducted using proprietary down-hole fracturing equipment. The resulting network of fractures containing sand proppant and/or bio-amendment enables the expeditious recovery or ISB of subsurface contaminants. The Bio-Frac ${ }^{\mathrm{TM}}$ process has been successfully used for incorporating biological amendments (i.e., chitin), surfactants, nutrient solutions, and chemical reagents with or without a sand proppant to distribute these amendments in contaminated soils and simultaneously enhance soil permeability, when required.

The Bio-Frac ${ }^{\mathrm{TM}}$ amendment that would be used in this approach is chitin. Once emplaced into the formation, the chitin degrades slowly producing a relatively long-lived source of nitrogen and electron donor in the form of volatile fatty acids.

Scoping calculations summarized in Appendix B suggest that the use of the Bio-Frac ${ }^{\mathrm{TM}}$ process with chitin is not a practical consideration for this site. If chitin is emplaced in the fractures, it has little effect on the aquifer at distance away from these fractures. In contrast, large volumes of an aqueous electron donor can be distributed further into the aquifer from the well. The large area of contamination and the slow contaminant transport velocities would require the construction of multiple hydraulically fractured wells to affect the area. Injection of an aqueous electron donor is likely a more effective means of delivering electron donor.

An estimate of the electron donor requirements and an estimate of the injection time and number of wells required to distribute electron donor solution are included in Appendix B. Large quantities of electron donor would need to be injected in order to achieve a concentration of sodium lactate in the aquifer that is sufficient to induce ARD. It is postulated that because a continuous source of TCE is not present and the aqueous TCE concentrations are generally less than $26 \mu \mathrm{g} / \mathrm{L}$, if sufficient lactate is delivered to the system, it may be enough to induce ARD and reduce the TCE concentrations to below MCLs. The most feasible electron donor delivery strategy would involve one or two long continuous injections into one or more wells followed by performance monitoring.

\subsection{Technical Description of Pump and Treat}

Pump and treat is a broad term used to describe the pumping of contaminated groundwater to the surface where it can be treated. The general goal of pump and treat implementation at TA-V would be to restore the aquifer by removing the mass of COCs from groundwater. The system would consist of at least one extraction well used to remove contaminated groundwater, an ex situ treatment system, and a disposal method for the treated water. A pump and treat technology is applied in three of the nine proposed remedial alternatives. The three remedial alternatives implement pump and treat combined with either MNA or groundwater monitoring.

Pump and treat implementation would treat a particular COC to applicable standards; therefore, a separate groundwater monitoring or MNA remedial alternative (beyond confirmatory monitoring) would not be required after completion of pump and treat. Depending on the method of ex-situ treatment, pump and treat can be implemented for VOCs and nitrate or for VOCs only. Disposal of the nitrate-contaminated water could be onsite reinjection to the aquifer, resulting in implementation of groundwater monitoring for nitrate. Therefore, these three remedial alternatives have been reduced to: 
- Pump and treat for VOCs and nitrate,

- Pump and treat for VOCs and groundwater monitoring for nitrate.

\subsubsection{Considerations for Evaluation of Pump and Treat}

Pump and treat is one of the most widely used groundwater technologies, as it is implemented at about three-quarters of the Superfund sites with contaminated groundwater and at most sites where cleanup is conducted under the Resource Conservation and Recovery Act (RCRA) and state laws (EPA 1996). It is a well-developed technology that is applicable for VOCs and nitrate. Pump and treat is appropriate for both contaminant reduction and containment of a contaminant plume.

A review of Environmental Protection Agency (EPA) literature on pump and treat reveals that this technology can have several significant disadvantages. The general goal of pump and treat at $\mathrm{TA}-\mathrm{V}$ is to remove contaminant mass from groundwater to restore the aquifer to beneficial use. Favorable conditions for accomplishing cleanup using pump and treat include the presence of contaminants that do not sorb and a homogeneous permeable aquifer; neither condition is present at TA-V. At TA-V, VOC contaminants that tend to sorb are present, and the aquifer is characterized by low permeability and heterogeneity.

Slow contaminant transport and interphase transfer has caused many pump and treat systems to continue to operate for decades. Sorption of VOCs to aquifer materials retards the movement of these contaminants toward extraction wells resulting in the need to flush multiple pore volumes of water through the contaminated aquifer zone to remove the contaminant mass (EPA 1997). An evaluation of 32 selected pump and treat systems showed that these systems require on average $\$ 4.9$ million in capital costs and $\$ 730,000$ in annual operating costs. Despite this, only two of the sites surveyed have been cleaned up (EPA 2001).

\subsubsection{Considerations for Implementing Pump and Treat at TA-V}

Site-specific characteristics must be considered to evaluate implementation of pump and treat at TA-V. New pumping wells are needed because the present locations of monitoring wells are not ideal pumping locations for plume capture, and the monitoring well network needs to be maintained. Additional site characterization may need to take place to identify appropriate locations for installation of new wells and impacts of pump and treat to hydrogeology of the aquifer underlying TA-V. Numerical modeling may be performed to estimate pumping performance under different aquifer properties, and aquifer testing may be conducted to estimate or verify predicted capture zones, compare contaminant distribution measurements to estimates, and obtain well yield information to estimate treatment volumes.

\subsubsection{Scoping Pumping Requirements at TA-V}

Approximate order-of-magnitude scoping calculations, using site specific information; have been performed to develop the conceptual designs summarized in Section 3. Two approaches to pump and treat were considered from EPA guidance (EPA 1997). These two approaches were:

- Capturing the contaminant plume as it is transported across a downgradient transect or plane, and 
- Removing a sufficient number of pore volumes from within the contaminated aquifer volume to restore the aquifer.

The first approach involves capturing the contaminant plume by creating a sufficient downgradient capture zone. The capture zone width was estimated according to the method summarized in EPA guidance (EPA 2002) and assuming a capture zone thickness of $30 \mathrm{ft}$ (Appendix C). Calculations revealed that, given the range of properties summarized in Section 1.2, a well pumped at its maximum capacity would create a capture zone several times wider than the width of the contaminant plume. However, as a result of the relatively slow contaminant transport (8-20 ft/yr) (SNL/NM 2004b), remediation using this method would require an unreasonably long time compared to other remedial alternatives.

The second approach involves removing groundwater from the contaminated zone and essentially flushing that zone with uncontaminated groundwater from outside the contaminated zone to remove dissolved contaminants and contaminants that are sorbed to aquifer materials or located within pore water that is not readily accessible. Extraction well(s) may be placed strategically to both contain the plume and remove contaminants. This is accomplished by removing multiple pore volumes of water. It has been suggested that it may be necessary to pump between 10 and 100 pore volumes to remove contaminants from an aquifer (EPA 1997).

Scoping calculations were performed to estimate the timeframe and operating parameters required to implement this strategy (Appendix $\mathrm{C}$ ). A wide range of remedial timeframes were calculated (Table 2-3). This range resulted from the range of observed specific capacities and the assumed range of pore volumes to be pumped (10 to 100) (EPA 1997). The remedial timeframe can range from the optimistic case of several years (assuming that only 10 pore volumes would need to be pumped and that extraction well(s) have a specific capacity of $0.86 \mathrm{gpm} / \mathrm{ft}$ of drawdown) to an impractical timeframe (i.e., over 1,000 years). More extraction wells may be constructed to reduce the remedial timeframe; however, from a cost/benefit point of view, the additional capital costs of drilling these wells and the cost of treating the increased volumes of contaminated water would be excessive compared to other technologies.

Table 2-3. Summary of pump-and-treat estimates.

\begin{tabular}{l|cc|cc}
\hline & \multicolumn{2}{|c|}{$\begin{array}{c}\text { Operations Time } \\
\text { (years) }\end{array}$} & \multicolumn{2}{c}{ Flow to be Treated } \\
(gpm)
\end{tabular}




\subsubsection{Scoping Treatment Options}

Several treatment options were considered for removal or degradation of VOC and/or nitrate contamination. These options include:

- Sorption of VOCs to granular activated carbon (GAC),

- Volatilization of VOCs using an air stripper,

- Treatment of both VOCs and nitrate in an ex-situ bioreactor,

- Removal of nitrate using ion exchange.

Two of the options listed above were found to not be practical for implementation. The options that were not considered practical are:

- Removal of VOCs using an air stripper. Both air stripping and treatment with GAC are only applicable to VOCs. These treatment options do not degrade the VOCs, but rather transfer the contaminant to another media or phase. The major disadvantage of treatment using air stripping is cost and commitment of resources would be significantly more than using GAC. Because air stripping requires a large reactor size that has a blower constantly running, it is more appropriate for higher concentrations than those present at TA-V. Because it is more practical to use GAC to achieve removal of VOCs, air stripping will no longer be considered as a treatment option.

- Treatment of both VOCs and nitrate in an ex-situ bioreactor. There are several designs for treatment of both VOCs and nitrate in an ex-situ biological reactor. The major advantage of this option is treatment of all COCs by degrading the compounds to innocuous products. However, this type of treatment has several major disadvantages that make it impractical for use at TA-V. First, the presence of competing electron acceptors (oxygen, nitrate, and sulfate) and the slow rate of dechlorination combine to require a long hydraulic retention time making the required reactor size very large. Second, it is difficult to maintain an active dechlorinating microbial community given the low chlorinated ethene concentrations. The ability to maintain this community is unknown and would be experimental. Third, waste streams (i.e., treated water and settled sludge) would contain biomass and would require disposing. Finally, the system requires the continued cost of extensive monitoring and constantly adding electron donor.

The other treatment options would be evaluated during pump and treat design. A conceptual design for each option is presented in Appendix D, including a list of advantages and disadvantages of each. Potential disposal options for treated water are also presented in Appendix D. These treatment options would be applied in the two remedial alternatives involving pump and treat in the following manner: 
- Pump and treat for VOCs and nitrate using GAC and ion-exchange. Treatment of contaminated water would involve removal of VOCs using GAC and removal of nitrate using ion exchange.

- Pump and treat for VOCs using GAC and groundwater monitoring for nitrate. Treatment of contaminated water would involve removal of VOCs using GAC. The treated water would contain nitrate and would either be disposed to the sanitary sewer or disposed on-site.

\subsection{Summary of Technology Descriptions}

Based on the technical descriptions of the remedial alternatives presented in this section, the nine remedial alternatives stated in the TA-V CME Work Plan (SNL/NM 2004a) have been reduced to:

1. Groundwater monitoring for VOCs and nitrate,

2. MNA for VOCs and nitrate,

3. MNA for VOCs and groundwater monitoring for nitrate,

4. ISB for VOCs and nitrate and MNA for VOCs,

5. Pump and treat for VOCs and nitrate using GAC and ion-exchange, and

6. Pump and treat for VOCs using GAC and groundwater monitoring for nitrate.

In summary, this new list of remedial alternatives was determined based on information in the technology descriptions. No changes were made to the first three remedial alternatives containing groundwater monitoring and/or MNA. Remedial alternatives containing ISB were narrowed from three to one because this technology would treat both VOC and nitrate and these contaminants are located in the same area. The treatment methods for remedial alternatives containing pump and treat were defined and since implementation of pump and treat would treat a particular COC to applicable standards, a separate technology following completion of pump and treat would not be required. 


\subsection{REMEDIAL ALTERNATIVE CONCEPTUAL DESIGNS}

The purpose of this section is to present conceptual designs of the remedial alternatives based on the technology descriptions provided in Section 2.0. The conceptual designs provide information for performing a preliminary remedial alternative evaluation and will be updated as laboratory, numerical modeling, and field studies provide more information. Conceptual designs for each remedial alternative include an overview of the remedial alternative, a description of the T\&FRs, and a list of the expected costs for each remedial alternative. The expected duration of each remedial alternative is addressed as it relates to other remedial alternatives. A duration of 30 years will be used when cost is estimated for remedial alternatives.

\subsection{Groundwater Monitoring for VOCs and Nitrate}

Groundwater monitoring for VOCs and nitrate would proceed as described in Section 2.1.

Figure 3-1 illustrates the process of implementing groundwater monitoring for VOCs and nitrate. The figure illustrates the necessary inputs and waste streams that will be part of the implementation.

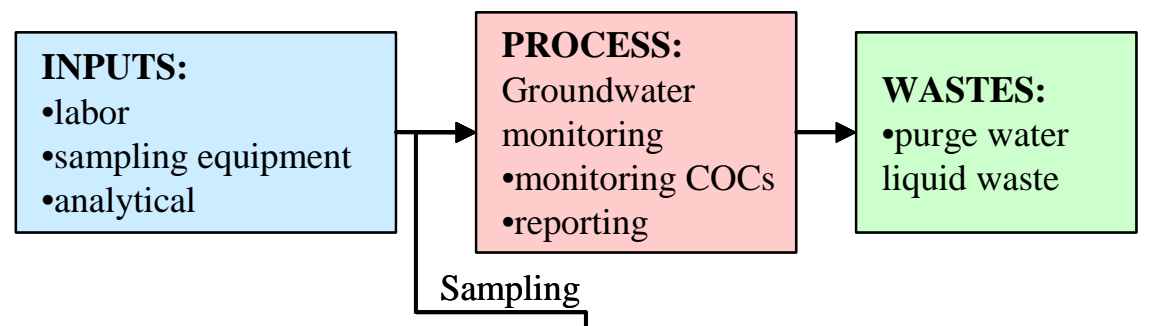

TA-V Well Network - only includes monitoring wells

Figure 3-1. Process diagram for groundwater monitoring for VOCs and nitrate.

\subsubsection{Technical and Functional Requirements}

Implementation of this approach requires the ability to monitor the contaminants (TCE, PCE, and nitrate) in groundwater. This requires that the existing monitoring well network be maintained. Monitoring would need to occur until it can be demonstrated that COCs are below clean-up goals, which would require no detections of COCs in monitoring wells for a period of time to be determined in the implementation work plan. Table 3-1 details the T\&FRs.

Assumptions include:

- Numerical modeling performed during the CME conclusively demonstrate that there is no risk to potential receptors.

- Groundwater monitoring, as performed under the current program, would be continued. This would include maintaining equipment, wells, utilities, and personnel.

- A sufficient monitoring well network exists. 
Table 3-1. T\&FRs for groundwater monitoring for VOCs and nitrate.

\begin{tabular}{l|l}
\hline \multicolumn{1}{c|}{ Parameter } & \multicolumn{1}{c}{ Requirement } \\
\hline $\begin{array}{l}\text { Duration of groundwater } \\
\text { monitoring }\end{array}$ & $\begin{array}{l}\text { Groundwater monitoring must continue until it is demonstrated that } \\
\text { contaminants are permanently below MCLs. }\end{array}$ \\
\hline $\begin{array}{l}\text { Frequency of } \\
\text { groundwater monitoring }\end{array}$ & Annual \\
\hline Analytes & $\begin{array}{l}\text { All COCs (PCE, TCE, and nitrate) and water levels must be } \\
\text { monitored. }\end{array}$ \\
\hline Reporting & $\begin{array}{l}\text { Annual reporting during performance operations; may be annual or } \\
\text { every 5 years for long-term operations. }\end{array}$ \\
\hline New monitoring wells & $\begin{array}{l}\text { If samples can no longer be taken from a monitoring well due to } \\
\text { water level decline, consideration must be given to replacing that } \\
\text { wells. New wells must be capable of monitoring the COC plume. }\end{array}$ \\
\hline $\begin{array}{l}\text { Depths of new } \\
\text { monitoring wells }\end{array}$ & $\begin{array}{l}\text { Monitoring wells would be drilled at a depth sufficient to penetrate } \\
\text { the contaminated zone. This would be determined using water-level } \\
\text { data from the prior year. }\end{array}$ \\
\hline Institutional controls & $\begin{array}{l}\text { All equipment necessary for monitoring including pumps, sample } \\
\text { bottles, power (generator or utilities), shipping supplies, purge water } \\
\text { tanks, personal protection equipment, and any other necessary } \\
\text { equipment. }\end{array}$ \\
\hline Equipment & $\begin{array}{l}\text { Storage for field sampling and waste containing equipment } \\
\text { including locking devices on wellheads. Administrative controls } \\
\text { would include postings on wellheads identifying potential hazards } \\
\text { and placement of written notification of this corrective measure in } \\
\text { the facility land-use master plan. }\end{array}$ \\
\hline Waste storage & $\begin{array}{l}\text { Storage of purge water until authorized to dispose. } \\
\text { antrols to protect current and future users from health risks }\end{array}$ \\
\hline &
\end{tabular}




\subsubsection{Cost}

Cost elements to be considered for implementing groundwater monitoring for VOCs and nitrate include capital equipment and operations and maintenance costs, as outlined in Table 3-2.

Table 3-2. Itemized cost elements for the groundwater monitoring for VOCs and nitrate remedial alternative.

\begin{tabular}{l|l}
\hline \multicolumn{1}{c|}{ Capital } & \multicolumn{1}{c}{ Operations and Maintenance } \\
\hline $\begin{array}{l}\text { - Costs associated with designing a } \\
\text { long-term groundwater monitoring } \\
\text { program }\end{array}$ & $\begin{array}{l}\text { - Costs of maintaining an adequate monitoring well } \\
\text { network for the duration of the remedy while } \\
\text { regional water levels decline. }\end{array}$ \\
$\begin{array}{l}\text { - Indirect costs (legal and permitting } \\
\text { fees) }\end{array}$ & $\begin{array}{l}\text { Sampling and analyses costs for the duration of } \\
\text { the remedy }\end{array}$ \\
- Reporting costs for the duration of the remedy \\
- Indirect operational costs including institutional \\
controls, contingency allowances, and \\
administrative costs
\end{tabular}

\subsection{MNA for VOCs and Nitrate}

This remedial alternative includes application of MNA for VOCs and nitrate. Implementation of this remedial alternative would consist of characterization and monitoring of natural attenuation mechanisms and monitoring attenuation of contaminants in the subsurface without active remediation. The general approach and mechanisms for MNA are described in Section 2.2. Figure 3-2 illustrates the process of implementing MNA for VOCs and nitrate. The figure illustrates the necessary inputs and waste streams that will be part of the implementation.

\begin{tabular}{|c|c|c|}
\hline $\begin{array}{l}\text { INPUTS: } \\
\text { •labor } \\
\text { •sampling equipment } \\
\text { •analytical } \\
\text { •Characterization of } \\
\text { natural attenuation } \\
\text { will effect the strategy }\end{array}$ & $\begin{array}{l}\text { PROCESS: Monitoring } \\
\text { •monitoring COCs } \\
\text { •monitoring attenuation } \\
\text { parameters } \\
\text { •data analyses } \\
\text {-reporting }\end{array}$ & $\begin{array}{l}\text { WASTE: } \\
\text { •purge water } \\
\text { liquid waste }\end{array}$ \\
\hline & Sampling & \\
\hline
\end{tabular}

Figure 3-2. Process diagram for MNA for VOCs and nitrate. 


\subsubsection{Technical and Functional Requirements}

Implementation of this approach must allow monitoring of contaminant attenuation mechanisms in the subsurface and the contaminant plume. This entails monitoring TCE, PCE, nitrate, and parameters to monitor attenuation mechanisms (i.e., redox parameters or dissolved gases). This monitoring would need to continue until clean-up goals are met. As mechanisms of natural attenuation are identified and numerical modeling is performed to predict contaminant transport, the number of wells to be monitored would be determined and predictions would be made to determine the duration of monitoring. Table 3-3 details the T\&FRs.

Table 3-3. T\&FRs for MNA for VOCs and nitrate.

\begin{tabular}{l|l}
\hline \multicolumn{1}{c|}{ Parameter } & \multicolumn{1}{c}{ Requirement } \\
\hline Duration of monitoring & To be determined \\
\hline Frequency of monitoring & Annual \\
\hline Analytes & $\begin{array}{l}\text { All COCs (PCE, TCE, and nitrate), water levels, and other } \\
\text { parameters necessary to monitor attenuation mechanisms } \\
\text { (i.e., redox conditions and enzyme probes) }\end{array}$ \\
\hline Analyses & $\begin{array}{l}\text { The groundwater monitoring data would be analyzed and } \\
\text { interpreted. This data would be used to monitor attenuation } \\
\text { mechanisms and track COC concentration changes. }\end{array}$ \\
\hline Reporting & $\begin{array}{l}\text { Annual reporting for the first 5 years, followed by reporting every } \\
\text { 5 years until the end of long-term operations. Reports would } \\
\text { include analysis of concentration trends and comparison to } \\
\text { predicted trends of attenuation. }\end{array}$ \\
\hline New monitoring wells & $\begin{array}{l}\text { If water levels continue to decline, the following wells would need } \\
\text { to be replaced between 2020 and 2041: TAV-MW3, TAV-MW4, } \\
\text { TAV-MW2, LWDS-MW1, TAV-MW8, and TAV-MW5. }\end{array}$ \\
\hline $\begin{array}{l}\text { Depths of new } \\
\text { monitoring wells } \\
\text { (if installed) }\end{array}$ & $\begin{array}{l}\text { Monitoring wells would be drilled at a depth sufficient to penetrate } \\
\text { the contaminated zone. This would be determined using water } \\
\text { level data for the past year. }\end{array}$ \\
\hline Equipment & $\begin{array}{l}\text { All equipment necessary for monitoring including pumps, sample } \\
\text { bottles, power (generator or utilities), shipping supplies, purge } \\
\text { water tanks, personal protection equipment, and any other } \\
\text { necessary equipment. }\end{array}$ \\
\hline Equipment storage & Storage for field sampling and waste containing equipment. \\
\hline Waste storage & $\begin{array}{l}\text { Storage of purge water until authorized to dispose. } \\
\text { admititutional controls would consist of engineering and } \\
\text { health risks associated with contaminated groundwater. } \\
\text { Engineering controls would consist of methods to restrict access to } \\
\text { contaminated water, including locking devices on wellheads. } \\
\text { Administrative controls would include postings on wellheads } \\
\text { identifying potential hazards and placing written notification of this } \\
\text { corrective measure in the facility land-use master plan. }\end{array}$ \\
\hline &
\end{tabular}


Assumptions include:

- Numerical modeling performed during the CME demonstrates that there is no unacceptable risk to potential receptors.

- Monitoring would not need to occur for longer than 30 years.

- Natural attenuation mechanisms for both VOCs and nitrate are identified.

- Necessary equipment, utilities, and personnel are available.

- A sufficient monitoring well network exists.

\subsubsection{Cost}

Costs of implementing MNA for VOCs and nitrate would include capital equipment and operations and maintenance costs as listed in Table 3-4.

Table 3-4. Itemized costs for the MNA for VOCs and nitrate remedial alternative.

\begin{tabular}{l|l}
\hline \multicolumn{1}{c|}{ Capital } & \multicolumn{1}{c}{ Operations and Maintenance } \\
\hline $\begin{array}{l}\text { - Costs associated with designing } \\
\text { a long-term groundwater } \\
\text { monitoring program }\end{array}$ & $\begin{array}{l}\text { - Costs of maintaining an adequate monitoring well } \\
\text { network for the duration of the remedy while } \\
\text { regional water levels decline. }\end{array}$ \\
$\begin{array}{l}\text { - Costs of characterizing natural } \\
\text { attenuation }\end{array}$ & - Sampling and analyses costs \\
$\begin{array}{l}\text { - Indirect costs (legal and } \\
\text { permitting fees) }\end{array}$ & - Reporting costs for the duration of the remedy. \\
& - Costs for data analyses and interpretation. \\
& $\begin{array}{l}\text { Indirect operational costs, including institutional } \\
\text { controls, contingency allowances, and administrative } \\
\text { costs }\end{array}$ \\
\hline
\end{tabular}

\subsection{MNA for VOCs and Groundwater Monitoring for Nitrate}

The proposed remedial alternative includes application of MNA for VOCs and groundwater monitoring for nitrate. Implementing MNA for VOCs would allow for characterization and prediction of attenuation mechanisms for VOCs and would monitor attenuation of these contaminants in the subsurface to daughter products without active remediation. The general approach and mechanisms for MNA are described in Section 2.2. Implementation of groundwater monitoring for nitrate would consist of the general approach discussed in Section 2.1. The process of implementing this remedial alternative is very similar to the approach demonstrated in Figures 3-1 and 3-2 with respect to nitrate and VOCs, respectively. In general, T\&FRs and cost elements would be similar to those summarized in Sections 3.2.2 and 3.2.3, respectively. 


\subsection{ISB for VOCs and Nitrate and MNA for VOCs}

Application of this remedial alternative at TA-V would begin with implementation of ISB for VOCs and nitrate. ISB implementation would target a high concentration zone of the plume within the influence of injection wells. MNA would be implemented for the lower concentration zones of the plume and for the entire plume following completion of ISB to further reduce contaminant concentrations and ensure that sufficient degradation would take place during the remedial timeframe. Figure 3-3 illustrates the process of implementing ISB for VOCs and nitrate and MNA for VOCs. The figure illustrates the necessary inputs and waste streams that will be part of the implementation. As demonstrated implementation of ISB would require more inputs that MNA or groundwater monitoring remedial alternatives.

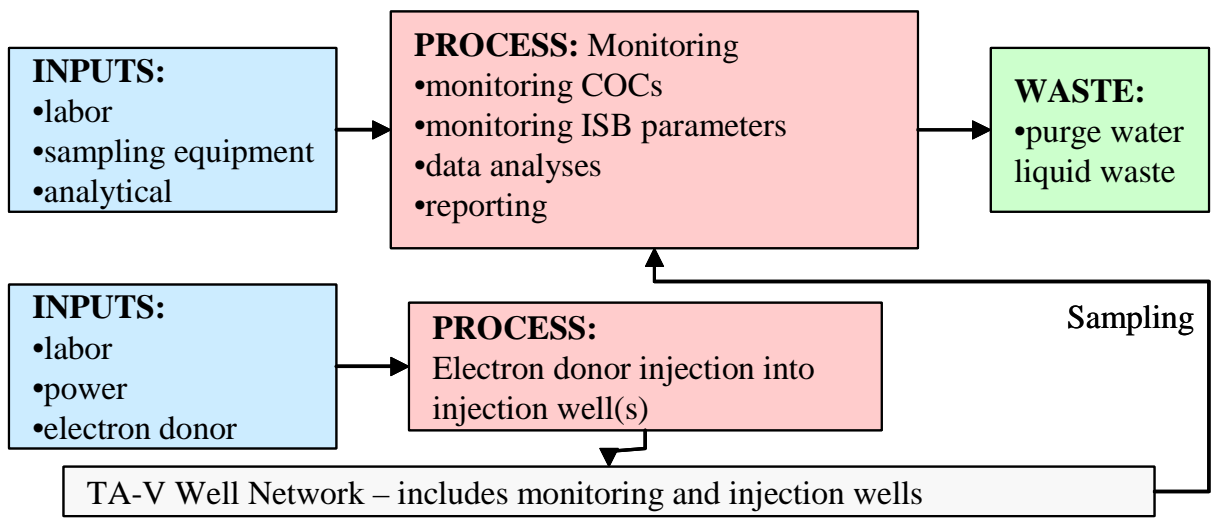

Figure 3-3. Process diagram for ISB for VOCs and nitrate and MNA for VOCs.

\subsubsection{Technical and Functional Requirements}

Implementation of this remedial alternative would require creating a biologically reduced zone in the TA-V groundwater to remediate groundwater containing TCE at concentrations of greater than $10 \mu \mathrm{g} / \mathrm{L}$. The electron donor addition system must emplace enough electron donor to cause denitrification and ARD. This system would be composed of at least one electron donor injection well and would include an electron donor injection facility. Table 3-5 lists the T\&FRs for this remedial alternative.

Assumptions include:

- Necessary equipment, utilities, and personnel are available.

- A dechlorinating microbial community can be induced by addition of electron donor.

- An injection well can be made to accept injection at a rate sufficient to achieve distribution of electron donor in a reasonable time period (see Appendix B).

- Assumptions stated in "Estimation of the Number of Wells Required for Electron donor Injection” (see Appendix B). 
Table 3-5. T\&FRs for ISB for VOCs and nitrate and MNA for VOCs.

Parameter Requirement

Duration of ISB operations would be determined prior to implementation.

Remedy duration It is estimated that ISB would require a relatively short implementation period followed by confirmatory monitoring. The implementation would require less time than the other remedies.

\begin{tabular}{|c|c|}
\hline $\begin{array}{l}\text { Injection operations } \\
\text { duration }\end{array}$ & $\begin{array}{l}\text { An injection event would require between } 60 \text { and } 110 \text { hours (assuming } \\
\text { high injection rates are feasible). There would be one to two injections. }\end{array}$ \\
\hline Injection well(s) & Between one and three injection wells would need to be constructed. \\
\hline Injection facility & $\begin{array}{l}\text { The injection facility would be capable of mixing electron donor into } \\
\text { potable water and injecting at a maximum of } 5 \text { gpm. The facility can be } \\
\text { temporary. }\end{array}$ \\
\hline Duration of monitoring & $\begin{array}{l}\text { Monitoring of groundwater would increase in frequency in all wells during } \\
\text { and for a short period of time after the electron donor injection(s). It is } \\
\text { estimated that monitoring would continue at a reduced frequency for } \\
\text { several years after the beginning of remedy implementation. }\end{array}$ \\
\hline Frequency of monitoring & $\begin{array}{l}\text { ISB monitoring would include sampling and analyses, in addition to MNA } \\
\text { monitoring that would be necessary to monitor the effect of electron donor } \\
\text { injections. A period of groundwater monitoring following ISB injections } \\
\text { would be required to confirm clean up goals are achieved. }\end{array}$ \\
\hline Analytes & $\begin{array}{l}\text { All COCs (PCE, TCE, and nitrate), water levels, parameters necessary to } \\
\text { monitor ISB operations (i.e., chemical oxygen demand to monitor electron } \\
\text { donor distribution and utilization), and parameters necessary to monitor } \\
\text { attenuation mechanisms (i.e., redox conditions). }\end{array}$ \\
\hline Analyses & $\begin{array}{l}\text { The groundwater monitoring data would be analyzed and interpreted. } \\
\text { Data would be used to track the performance of ISB and monitor } \\
\text { contaminant reduction. }\end{array}$ \\
\hline Reporting & $\begin{array}{l}\text { Annual reporting for first } 5 \text { years, followed by annual data summaries with } \\
\text { formal supports submitted every } 5 \text { years until the end of long-term } \\
\text { operations. Reports would include analysis of concentration trends and } \\
\text { comparison to predicted trends of attenuation. }\end{array}$ \\
\hline Sampling equipment & $\begin{array}{l}\text { All equipment necessary for monitoring, including pumps, sample bottles, } \\
\text { power (generator or utilities), shipping supplies, purge water tanks, } \\
\text { personal protection equipment, and any other necessary equipment. }\end{array}$ \\
\hline Equipment storage & Storage for field sampling and waste containing equipment \\
\hline Waste storage & Storage of purge water until authorized to dispose. \\
\hline Institutional controls & $\begin{array}{l}\text { Institutional controls would consist of engineering and administrative } \\
\text { controls to protect current and future users from health risks associated } \\
\text { with contaminated groundwater. Engineering controls would consist of } \\
\text { methods to restrict access to contaminated water, including locking } \\
\text { devices on wellheads. Administrative controls would include postings on } \\
\text { wellheads identifying potential hazards and placing written notification of } \\
\text { this corrective measure in the facility land-use master plan. }\end{array}$ \\
\hline
\end{tabular}




\subsubsection{Cost}

Cost elements for implementing ISB for VOCs and nitrate and MNA for VOCs would include capital and operations and maintenance costs, as listed in Table 3-6.

Table 3-6. Itemized costs for the ISB and MNA for VOCs and ISB for nitrate remedial alternative.

\begin{tabular}{l|l}
\hline \multicolumn{1}{c|}{ Capital } & \multicolumn{1}{c}{ Operations and Maintenance } \\
\hline $\begin{array}{l}\text { - Engineering costs to design ISB } \\
\text { implementation }\end{array}$ & $\begin{array}{l}\text { - Includes labor, material, and equipment costs to } \\
\text { inject continuously for approximately 17 days. } \\
\text { Also includes the cost of approximately } 300 \text { drums } \\
\text { of sodium lactate or other electron donor. }\end{array}$ \\
$\begin{array}{l}\text { - Construction of injection well(s), } \\
\text { which may include hydraulic } \\
\text { fracturing. }\end{array}$ & $\begin{array}{l}\text { Sampling and analyses costs (sampling and } \\
\text { analyses may be more extensive to monitor redox } \\
\text { conditions). }\end{array}$ \\
$\begin{array}{l}\text { - Construction of an injection } \\
\text { facility. }\end{array}$ & $\begin{array}{l}\text { Reporting costs for the duration of the remedy } \\
\text { (the remedy may require less time and fewer } \\
\text { reports). }\end{array}$ \\
fees) & $\begin{array}{l}\text { Costs for data analyses and interpretation. } \\
\text { Indirect costs (legal and permitting }\end{array}$ \\
& $\begin{array}{l}\text { Indirect operational costs including institutional } \\
\text { controls, contingency allowances, and } \\
\text { administrative costs }\end{array}$ \\
\hline
\end{tabular}

\subsection{Pump and Treat for VOCs and Nitrate using GAC and Ion-Exchange}

Application of this remedial alternative at TA-V would involve extraction of contaminated groundwater treating the water for all COCs. The water would be extracted sufficiently long to remove contaminants in the aquifer to below MCLs. Figure 3-4 illustrates the process of implementing pump and treat for VOCs and nitrate using GAC and ion-exchange. The figure illustrates the necessary inputs and waste streams that will be part of the implementation. As demonstrated implementation of this remedial alternative would require more inputs than MNA or groundwater monitoring remedial alternatives and would produce additional waste streams.

\subsubsection{Technical and Functional Requirements}

Implementation of this remedial alternative would require pumping contaminated groundwater to the surface, treating the water for COCs to concentrations below clean-up goals, and disposing the water. The system would be composed of extraction wells, a treatment facility, and, depending on the disposal option chosen, may also require an injection well. Table 3-7 illustrates the T\&FRs for this remedial alternative. 


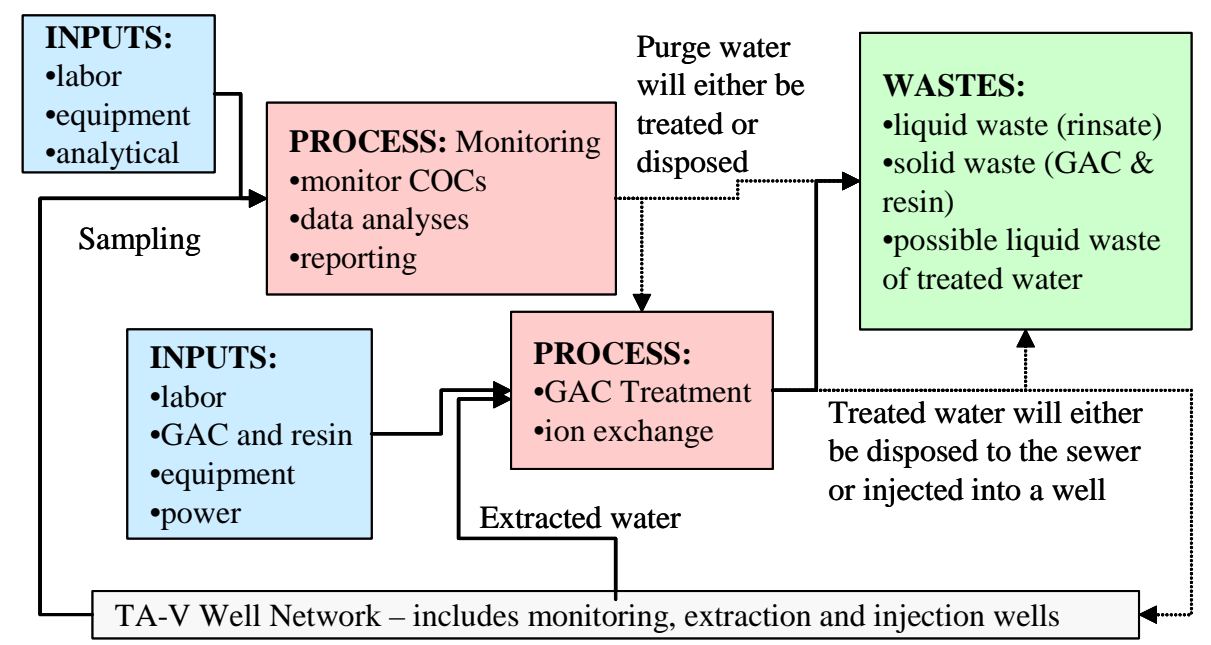

Figure 3-4. Process diagram for implementation of pump and treat for VOCs and nitrate.

Assumptions include:

- Necessary equipment, utilities, and personnel are available.

- Assumptions regarding pumping multiple pore volumes, as discussed in Section 2.4.3 and Appendix C.

- The treatment facility would be able to remove TCE and nitrate to below MCLs.

\subsubsection{Cost}

Costs of implementing pump and treat for VOCs and nitrate using GAC and ion exchange would include capital and operations and maintenance costs, as listed in Table 3-8.

\subsection{Pump and Treat for VOCs using GAC and Groundwater Monitoring for Nitrate}

Application of this remedial alternative at TA-V would include pumping contaminated groundwater from a high concentration zone and treating the water for VOCs. The treated water would be disposed without treating the water for nitrate. Groundwater monitoring for nitrate would track nitrate concentrations in the aquifer. The process of implementing this remedial alternative would be very similar to that summarized in Figure 3-4, with the exception that the ion exchange unit would not be part of the treatment requirements. T\&FRs and costs for this remedial alternative would be similar to those summarized in Sections 3.5.1 and 3.5.2, respectively, with the exception that ion-exchange would not be applied, thus reducing capital and operations and maintenance costs and eliminating the production of the brine regeneration solution. 
Table 3-7. T\&FRs for pump and treat for VOCs and nitrate using GAC and ion-exchange.

\begin{tabular}{|c|c|}
\hline Parameter & Requirement \\
\hline Extraction well(s) & $\begin{array}{l}\text { Extraction well(s) would be constructed that penetrate and are screened } \\
\text { across the contaminated zone of the aquifer. }\end{array}$ \\
\hline Treatment facility & $\begin{array}{l}\text { The treatment facility building would be composed of a modified sea-van, } \\
\text { equipped with electric power and plumbing to the sewer system. }\end{array}$ \\
\hline Treatment equipment & $\begin{array}{l}\text { GAC and ion exchange would be used to remove TCE and nitrate. } \\
\text { Replacement of GAC and regeneration of resins will also be necessary (see } \\
\text { Appendix D for estimates of operating requirements). }\end{array}$ \\
\hline Extraction rate & Extraction rate may range from less than 1 to over 20 gpm per well. \\
\hline Pump and treat duration & $\begin{array}{l}\text { Pump and treat would operate for a period of time ranging from as little as } \\
5 \text { years to over } 2000 \text { years. }\end{array}$ \\
\hline Duration of monitoring & $\begin{array}{l}\text { Groundwater monitoring would continue throughout pumping operations } \\
\text { and for a period of } 5 \text { years following or until clean-up objectives are } \\
\text { achieved. }\end{array}$ \\
\hline Frequency of monitoring & $\begin{array}{l}\text { Regular monitoring of treatment facility influent, effluent and intermediate } \\
\text { sampling ports would be required. Groundwater monitoring would be } \\
\text { required during pump and treat operations and following pump and treat } \\
\text { operations until achievement of clean up goals is confirmed. }\end{array}$ \\
\hline Analytes & All COCs (PCE, TCE, and nitrate) and water levels must be monitored. \\
\hline Analyses & $\begin{array}{l}\text { The groundwater monitoring data would be analyzed and interpreted. Data } \\
\text { would be used to track the performance of pump and treat and monitor } \\
\text { contaminant reduction. }\end{array}$ \\
\hline Reporting & $\begin{array}{l}\text { Annual reporting for first } 5 \text { years, followed by reporting every } 5 \text { years until } \\
\text { the end of long-term operations. Reports would include analysis of } \\
\text { concentration trends and comparison to predicted trends of attenuation. }\end{array}$ \\
\hline Sampling equipment & $\begin{array}{l}\text { All equipment necessary for monitoring including Bennett pumps, sample } \\
\text { bottles, power (generator or utilities), shipping supplies, purge water tanks, } \\
\text { personal protection equipment, and any other necessary equipment. }\end{array}$ \\
\hline Equipment storage & Storage for field sampling and waste containing equipment \\
\hline Waste storage & Storage for spent GAC containing sorbed TCE. \\
\hline Institutional controls & $\begin{array}{l}\text { Institutional controls would consist of engineering and administrative } \\
\text { controls to protect current and future users from health risks associated } \\
\text { with contaminated groundwater. Engineering controls would consist of } \\
\text { methods to restrict access to contaminated water, including locking devices } \\
\text { on wellheads. Administrative controls would include postings on } \\
\text { wellheads identifying potential hazards and placing written notification of } \\
\text { this corrective measure in the facility land-use master plan. }\end{array}$ \\
\hline
\end{tabular}


Table 3-8. Itemized costs for pump and treat for VOCs and nitrate.

\begin{tabular}{|c|c|}
\hline Capital & Operations and Maintenance \\
\hline $\begin{array}{l}\text { - Engineering costs to design pump } \\
\text { and treat implementation }\end{array}$ & $\begin{array}{l}\text { Costs associated with operations and maintenance } \\
\text { of the treatment facility. These would include } \\
\text { replacement of GAC, regeneration of resin, labor, } \\
\text { power, and other equipment costs. }\end{array}$ \\
\hline $\begin{array}{l}\text { - Construction of extraction well(s). } \\
\text { May also include construction of an } \\
\text { injection well. }\end{array}$ & $\begin{array}{l}\text { - Sampling and analyses costs. In addition to } \\
\text { monitoring groundwater sampling and analyses } \\
\text { would also include monitoring influent, effluent and } \\
\text { other water samples from the treatment facility). }\end{array}$ \\
\hline $\begin{array}{l}\text { - Construction of treatment facility } \\
\text { and installation of treatment } \\
\text { equipment (GAC drums and ion } \\
\text { exchange unit). }\end{array}$ & - Costs for data analyses and interpretation. \\
\hline \multirow[t]{2}{*}{$\begin{array}{l}\text { - Indirect costs (legal and permitting } \\
\text { fees) }\end{array}$} & $\begin{array}{l}\text { Reporting costs for the duration of the remedy } \\
\text { (the remedy may require less time and fewer } \\
\text { reports). }\end{array}$ \\
\hline & $\begin{array}{l}\text { - Indirect operational costs including institutional } \\
\text { controls, contingency allowances, and } \\
\text { administrative costs }\end{array}$ \\
\hline
\end{tabular}

B-46 


\subsection{PRELIMINARY REMEDIAL ALTERNATIVE EVALUATION}

The remedial alternative conceptual designs provided in this report summarize implementation strategies for remedial alternatives to support a preliminary remedial alternative evaluation. The preliminary evaluation is intended to identify remedial alternatives that should be investigated through field, laboratory, or numerical modeling studies. Each remedial alternative is evaluated using the threshold and remedial alternative criteria, as stated in the TA-V CME Work Plan (SNL/NM 2004a). The outcome of this evaluation is a list of remedial alternatives to be considered in further evaluation and recommendations of additional studies to fill data gaps identified for those remedial alternatives.

\subsection{Threshold Criteria Evaluation}

As specified in the COOC (NMED 2004), each remedial alternative must be evaluated based on the threshold criteria. Descriptions of the threshold criteria are stated in the TA-V CME Work Plan (SNL/NM 2004a). The following threshold criteria were evaluated:

- Protect human health and the environment,

- Attain media cleanup standard or alternative, approved risk-based cleanup goals, and

- Comply with standards for management of wastes.

As discussed in the TA-V Current Conceptual Model (SNL/NM 2004b), no source of residual contaminants remains at TA-V; therefore, the source control threshold criterion was not evaluated. Remedial alternative conceptual design information was used to determine if the remedial alternative meets the threshold criterion. This evaluation was a YES/NO evaluation. The results of this evaluation are presented in Table 4-1. As demonstrated, all of the remedial alternatives received a YES rating for each of the three categories.

\subsection{Remedial Alternative Evaluation}

Because all remedial alternatives passed the threshold criteria evaluation, they were evaluated based on the remedial alternative evaluation criteria. The remedial alternative evaluation criteria are described in the TA-V CME Work Plan (SNL/NM 2004a). As specified in the COOC

(NMED 2004), the remedial alternative evaluation must be balanced and includes the following:

- Long-term reliability and effectiveness,

- Reduction of toxicity, mobility, or volume,

- Short-term effectiveness,

- Feasibility,

- Capital cost, and

- Operations and maintenance cost. 
Table 4-1. Threshold criteria evaluation.

\begin{tabular}{|c|c|c|c|}
\hline Remedial Alternatives & $\begin{array}{c}\text { Protective of } \\
\text { Human } \\
\text { Health and } \\
\text { Environment }\end{array}$ & $\begin{array}{c}\text { Attain } \\
\text { Media } \\
\text { Cleanup } \\
\text { Standards } \\
\end{array}$ & $\begin{array}{c}\text { Waste } \\
\text { Management } \\
\text { Standards } \\
\text { Compliance } \\
\end{array}$ \\
\hline $\begin{array}{l}\text { Groundwater monitoring for VOCs and } \\
\text { nitrate }\end{array}$ & YES & YES & YES \\
\hline MNA for VOCs and nitrate & YES & YES & YES \\
\hline $\begin{array}{l}\text { MNA for VOCs and groundwater } \\
\text { monitoring for nitrate }\end{array}$ & YES & YES & YES \\
\hline $\begin{array}{l}\text { ISB for VOCs and nitrate and MNA for } \\
\text { VOCs }\end{array}$ & YES & YES & YES \\
\hline $\begin{array}{l}\text { Pump and treat for VOCs and nitrate using } \\
\text { GAC and ion-exchange }\end{array}$ & YES & YES & YES \\
\hline $\begin{array}{l}\text { Pump and treat for VOCs using GAC and } \\
\text { groundwater monitoring for nitrate }\end{array}$ & YES & YES & YES \\
\hline
\end{tabular}

YES = the remedial alternative meets the threshold criterion

$\mathrm{NO}=$ the remedial alternative does not meet the threshold criterion

1. Note: The threshold criterion, Source Control, is not included since a secondary source of release is not present in the vadose zone or saturated zone at TA-V.

The remedial alternative conceptual design information was used to perform a comparative analysis for each remedial alternative using the remedial alternative threshold criteria, and screen remedial alternatives that should no longer be considered in data gathering activities. The comparative analysis was performed using the following ratings:

$$
\begin{aligned}
& \text { "Not effective" = = Does not effectively meet the remedial alternative criterion } \\
& \text { within a timeframe that is comparable to other remedial } \\
& \text { alternatives, } \\
& \text { “+” } \quad=\quad \text { Effectively meets the remedial alternative criterion, and } \\
& \text { “+ + = } \quad \text { More effectively meets the remedial alternative criterion. }
\end{aligned}
$$

The total number of pluses represents how effectively the remedial alternative meets the criterion. A "Not effective" rating receives no score. Therefore, with six categories, the possible scores range from $0-12$. This approach balances the criteria in order to evaluate each remedial alternative in a simple, comparative manner. Information supporting comparative analysis of the remedial alternatives is presented in Table 4-2, and the results of the analyses are presented in Table 4-3. The supporting information states a rationale for the comparative analysis rating assigned to each remedial alternative for each criterion. This includes comparison of remedial alternatives and identifying data gaps. Data gaps are identified where additional information is needed to accurately rate the criterion and this information can be collected in a cost- and time-efficient manner. 
Table 4-2. Information supporting comparative analysis of the remedial alternatives.

\begin{tabular}{|c|c|c|c|c|c|c|}
\hline \multirow[b]{2}{*}{$\begin{array}{c}\text { Remedial } \\
\text { Alternatives }\end{array}$} & \multirow[b]{2}{*}{ 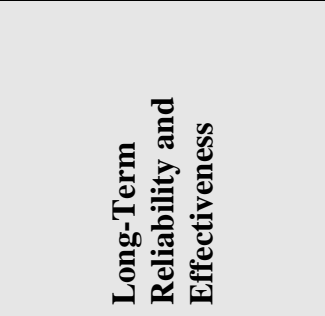 } & \multirow[b]{2}{*}{ 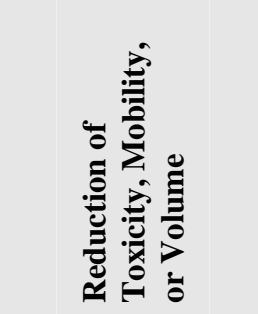 } & \multirow[b]{2}{*}{ 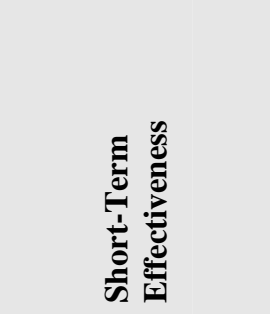 } & \multirow[b]{2}{*}{ 胥 } & \multicolumn{2}{|c|}{ Cost } \\
\hline & & & & & 预 & 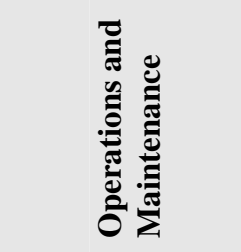 \\
\hline $\begin{array}{l}\text { Groundwater } \\
\text { monitoring for VOCs } \\
\text { and nitrate }\end{array}$ & $\begin{array}{l}\text { Data gap. The CME } \\
\text { process must } \\
\text { demonstrate that there } \\
\text { is no risk to receptors } \\
\text { without considering } \\
\text { degradation. If it is } \\
\text { demonstrated that } \\
\text { there is no long-term } \\
\text { risk in leaving } \\
\text { contaminants in place, } \\
\text { then the remedy is } \\
\text { effective because the } \\
\text { process of monitoring } \\
\text { groundwater is reliable } \\
\text { and is effective at } \\
\text { tracking contaminants. }\end{array}$ & $\begin{array}{l}\text { Would not consider } \\
\text { toxicity reduction. }\end{array}$ & $\begin{array}{l}\text { There is no } \\
\text { immediate reduction } \\
\text { in contaminant } \\
\text { concentration, but } \\
\text { short-term risk is } \\
\text { less than pump and } \\
\text { treat where } \\
\text { contaminants are } \\
\text { brought to the } \\
\text { surface.. }\end{array}$ & $\begin{array}{l}\text { Ready to implement } \\
\text { immediately. }\end{array}$ & $\begin{array}{l}\text { There is little cost } \\
\text { to implement. }\end{array}$ & $\begin{array}{l}\text { The timeframe of } \\
\text { continued } \\
\text { monitoring may be } \\
\text { longer than more } \\
\text { active remedial } \\
\text { alternatives. There } \\
\text { is a possible need } \\
\text { to replace } \\
\text { monitoring wells. }\end{array}$ \\
\hline $\begin{array}{l}\text { MNA for VOCs and } \\
\text { nitrate }\end{array}$ & $\begin{array}{l}\text { Data gap. If numerical } \\
\text { modeling and/or field } \\
\text { studies demonstrate that } \\
\text { natural attenuation } \\
\text { mechanisms are } \\
\text { operable, then this } \\
\text { remedial alternative will } \\
\text { be effective. }\end{array}$ & $\begin{array}{l}\text { Data gap. Need to } \\
\text { identify MNA } \\
\text { mechanisms and } \\
\text { implementation } \\
\text { timeframe. }\end{array}$ & $\begin{array}{l}\text { There is no } \\
\text { immediate reduction } \\
\text { in contaminant } \\
\text { concentration, but } \\
\text { short-term risk is } \\
\text { less than pump and } \\
\text { treat where } \\
\text { contaminants are } \\
\text { brought to the } \\
\text { surface. }\end{array}$ & $\begin{array}{l}\text { Ready to implement } \\
\text { immediately. }\end{array}$ & $\begin{array}{l}\text { There is little cost } \\
\text { to implement. }\end{array}$ & $\begin{array}{l}\text { The timeframe of } \\
\text { continued } \\
\text { monitoring may be } \\
\text { longer than more } \\
\text { active remedial } \\
\text { alternatives. There } \\
\text { is a possible need } \\
\text { to replace } \\
\text { monitoring wells. }\end{array}$ \\
\hline
\end{tabular}


Table 4-2. (continued).

\begin{tabular}{|c|c|c|c|c|c|c|}
\hline \multirow[b]{2}{*}{$\begin{array}{c}\text { Remedial } \\
\text { Alternatives }\end{array}$} & \multirow[b]{2}{*}{ 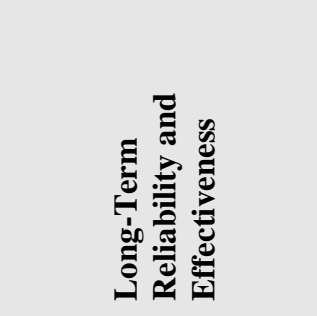 } & \multirow[b]{2}{*}{ 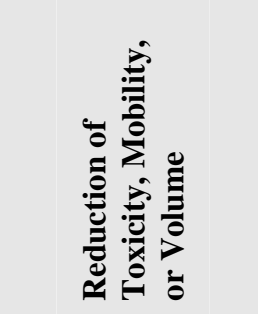 } & \multirow[b]{2}{*}{ ま } & \multirow[b]{2}{*}{ : } & \multicolumn{2}{|c|}{ Cost } \\
\hline & & & & & نี & 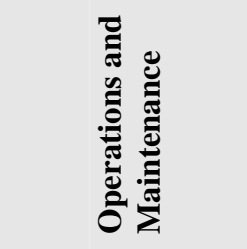 \\
\hline $\begin{array}{l}\text { MNA for VOCs and } \\
\text { groundwater } \\
\text { monitoring for nitrate }\end{array}$ & $\begin{array}{l}\text { With regard to VOCs, } \\
\text { this is a data gap. If } \\
\text { numerical modeling } \\
\text { and/or field studies } \\
\text { demonstrate that natural } \\
\text { attenuation mechanisms } \\
\text { are operable, then this } \\
\text { remedial alternative will } \\
\text { be effective. } \\
\text { With regard to nitrate, } \\
\text { this remedial alternative } \\
\text { would not involve } \\
\text { monitoring natural } \\
\text { attenuation mechanisms. } \\
\text { The CME process must } \\
\text { demonstrate that there is } \\
\text { no risk to receptors } \\
\text { without considering } \\
\text { degradation. }\end{array}$ & $\begin{array}{l}\text { Would not consider } \\
\text { toxicity reduction. }\end{array}$ & $\begin{array}{l}\text { There is no } \\
\text { immediate reduction } \\
\text { in contaminant } \\
\text { concentration, but } \\
\text { short-term risk is } \\
\text { less than pump and } \\
\text { treat where } \\
\text { contaminants are } \\
\text { brought to the } \\
\text { surface. }\end{array}$ & $\begin{array}{l}\text { Ready to implement } \\
\text { immediately. }\end{array}$ & $\begin{array}{l}\text { There is little cost } \\
\text { to implement. }\end{array}$ & $\begin{array}{l}\text { The timeframe of } \\
\text { continued } \\
\text { monitoring may be } \\
\text { longer than more } \\
\text { active remedial } \\
\text { alternatives. There } \\
\text { is a possible need } \\
\text { to replace } \\
\text { monitoring wells. }\end{array}$ \\
\hline $\begin{array}{l}\text { ISB for VOCs and } \\
\text { nitrate and MNA for } \\
\text { VOCs }\end{array}$ & $\begin{array}{l}\text { Successful } \\
\text { implementation of ISB } \\
\text { will degrade } \\
\text { contaminants and } \\
\text { remove long term risk of } \\
\text { exposure }\end{array}$ & $\begin{array}{l}\text { Reduces toxicity in } \\
\text { situ, by degrading } \\
\text { COCs. }\end{array}$ & $\begin{array}{l}\text { Reduces } \\
\text { contaminant } \\
\text { concentrations with } \\
\text { less short-term risk } \\
\text { than pump and treat } \\
\text { where contaminants } \\
\text { are brought to the } \\
\text { surface.. }\end{array}$ & $\begin{array}{l}\text { Technically more } \\
\text { difficult than MNA } \\
\text { or groundwater } \\
\text { monitoring since } \\
\text { construction of } \\
\text { infrastructure is } \\
\text { required, and } \\
\text { distribution of } \\
\text { electron donor may } \\
\text { prove difficult. }\end{array}$ & $\begin{array}{l}\text { Requires } \\
\text { construction of } \\
\text { new injection } \\
\text { well(s) and } \\
\text { injection } \\
\text { equipment. }\end{array}$ & $\begin{array}{l}\text { Requires purchase } \\
\text { of large amounts of } \\
\text { electron donor, but } \\
\text { over the remedial } \\
\text { alternative lifetime } \\
\text { may require less } \\
\text { monitoring than } \\
\text { MNA. }\end{array}$ \\
\hline
\end{tabular}


Table 4-2. (continued).

\begin{tabular}{|c|c|c|c|c|c|c|}
\hline \multirow[b]{2}{*}{$\begin{array}{c}\text { Remedial } \\
\text { Alternatives }\end{array}$} & \multirow[b]{2}{*}{ 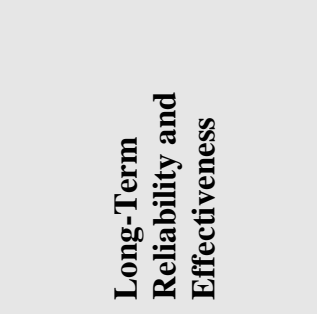 } & \multirow[b]{2}{*}{ 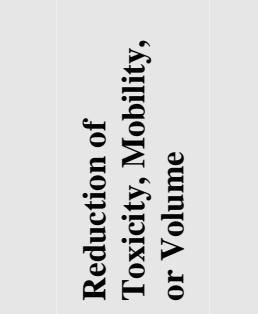 } & \multirow[b]{2}{*}{ 童异 } & \multirow[b]{2}{*}{ 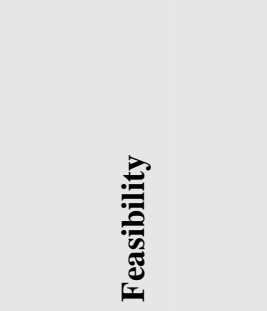 } & \multicolumn{2}{|c|}{ Cost } \\
\hline & & & & & 氠 & 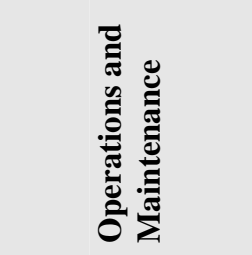 \\
\hline $\begin{array}{l}\text { Pump and treat for } \\
\text { VOCs and nitrate } \\
\text { using GAC and ion- } \\
\text { exchange }\end{array}$ & $\begin{array}{l}\text { A pump and treat system } \\
\text { may not be reliable to } \\
\text { restore the aquifer. } \\
\text { Estimates of remedial } \\
\text { alternative timeframe } \\
\text { range from several years } \\
\text { to indefinitely. } \\
\text { Requires disposal of } \\
\text { significant volumes of } \\
\text { waste streams for the } \\
\text { duration of operations. }\end{array}$ & $\begin{array}{l}\text { It may be difficult } \\
\text { to extract } \\
\text { contaminants from } \\
\text { the aquifer, and } \\
\text { contaminants are } \\
\text { transferred to a } \\
\text { different media } \\
\text { instead of destroyed } \\
\text { in groundwater. }\end{array}$ & $\begin{array}{l}\text { There may be an } \\
\text { immediate reduction } \\
\text { in concentration, but } \\
\text { contaminants are } \\
\text { brought to the } \\
\text { surface increasing } \\
\text { risk of exposure. }\end{array}$ & $\begin{array}{l}\text { Easily implemented, } \\
\text { but may require a } \\
\text { long period of } \\
\text { operations }\end{array}$ & $\begin{array}{l}\text { Requires well } \\
\text { drilling and } \\
\text { construction of } \\
\text { infrastructure. }\end{array}$ & $\begin{array}{l}\text { Operation duration } \\
\text { could be very long } \\
\text { requiring } \\
\text { considerable cost } \\
\text { in maintaining a } \\
\text { treatment system } \\
\text { and pumping wells. } \\
\text { Declining water } \\
\text { levels may also } \\
\text { affect the remedial } \\
\text { alternative. }\end{array}$ \\
\hline $\begin{array}{l}\text { Pump and treat for } \\
\text { VOCs using GAC and } \\
\text { groundwater } \\
\text { monitoring for nitrate }\end{array}$ & $\begin{array}{l}\text { A pump and treat system } \\
\text { may not be reliable to } \\
\text { restore the aquifer. } \\
\text { Estimates of remedial } \\
\text { alternative timeframe } \\
\text { range from several years } \\
\text { to indefinitely. } \\
\text { Requires disposal of } \\
\text { significant volumes of } \\
\text { waste streams for the } \\
\text { duration of operations. }\end{array}$ & $\begin{array}{l}\text { It may be difficult } \\
\text { to extract } \\
\text { contaminants from } \\
\text { the aquifer, and } \\
\text { contaminants are } \\
\text { transferred to a } \\
\text { different media } \\
\text { instead of destroyed } \\
\text { in groundwater. }\end{array}$ & $\begin{array}{l}\text { There may be an } \\
\text { immediate reduction } \\
\text { in concentration, but } \\
\text { contaminants are } \\
\text { brought to the } \\
\text { surface increasing } \\
\text { risk of exposure. }\end{array}$ & $\begin{array}{l}\text { Easily implemented, } \\
\text { but may require a } \\
\text { long period of } \\
\text { operations. }\end{array}$ & $\begin{array}{l}\text { Requires well } \\
\text { drilling and } \\
\text { construction of } \\
\text { infrastructure. }\end{array}$ & $\begin{array}{l}\text { Operation duration } \\
\text { could be very long } \\
\text { requiring } \\
\text { considerable cost } \\
\text { in maintaining a } \\
\text { treatment system } \\
\text { and pumping wells. } \\
\text { Declining water } \\
\text { levels may also } \\
\text { affect the remedial } \\
\text { alternative. }\end{array}$ \\
\hline
\end{tabular}


Table 4-3. Comparative analysis of remedial alternatives for TA-V.

\begin{tabular}{|c|c|c|c|c|c|c|c|}
\hline \multirow[b]{2}{*}{ Remedial Alternatives } & \multirow[b]{2}{*}{ 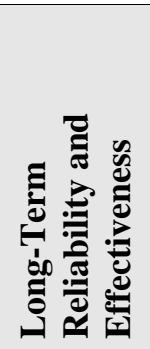 } & \multirow[b]{2}{*}{ 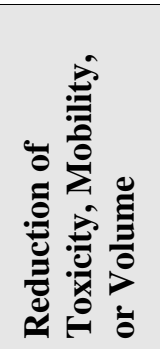 } & \multirow[b]{2}{*}{ 竞 } & \multirow[b]{2}{*}{ 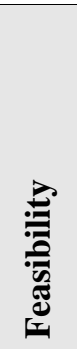 } & \multicolumn{2}{|c|}{ Cost } & \multirow[b]{2}{*}{ Totals } \\
\hline & & & & & $\begin{array}{l}\overline{\tilde{\Xi}} \\
\text { ज्ञ }\end{array}$ & 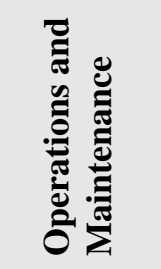 & \\
\hline Groundwater monitoring for VOCs and nitrate & ++ & $\begin{array}{l}\text { Not } \\
\text { effective }\end{array}$ & + & ++ & ++ & + & 8 \\
\hline MNA for VOCs and nitrate & ++ & + & + & ++ & ++ & + & 9 \\
\hline $\begin{array}{l}\text { MNA for VOCs and groundwater monitoring } \\
\text { for nitrate }\end{array}$ & + & + & + & ++ & ++ & + & 8 \\
\hline ISB for VOCs and nitrate and MNA for VOCs & ++ & ++ & ++ & + & + & + & 9 \\
\hline $\begin{array}{l}\text { Pump and treat for VOCs and nitrate using } \\
\text { GAC and ion-exchange }\end{array}$ & $\begin{array}{l}\text { Not } \\
\text { effective }\end{array}$ & + & + & + & + & $\begin{array}{c}\text { Not } \\
\text { effective }\end{array}$ & 4 \\
\hline $\begin{array}{l}\text { Pump and treat for VOCs using GAC and } \\
\text { groundwater monitoring for nitrate }\end{array}$ & $\begin{array}{c}\text { Not } \\
\text { effective }\end{array}$ & + & + & + & + & $\begin{array}{c}\text { Not } \\
\text { effective }\end{array}$ & 4 \\
\hline
\end{tabular}


The comparative analyses shown in Table 4-3 demonstrate that the two remedial alternatives involving pump and treat are considerably less effective than the other four remedial alternatives. As discussed in Sections 2 and 3, pump and treat (with the goal of restoring the aquifer or removing contaminant mass from the aquifer) has significant challenges due to retardation of the contaminants and low permeability of the aquifer. Pump and treat may be effective for containment of contaminant plumes and mass removal of the contaminant from extracted groundwater, however, pump and treat technology is not effective for reduction of concentration in groundwater and aquifer remediation. In order to accomplish aquifer restoration, it is necessary to pump and treat multiple pore volumes of water from the aquifer, which would be significantly more difficult than implementing ISB or MNA. As discussed in the CME Work Plan for TA-V (SNL/NM 2004a), if a remedial alternative is determined to be significantly less effective than the other remedial alternatives, then it will no longer be considered. It is recommended that the two remedial alternatives, pump and treat for VOCs and nitrate with GAC and ion exchange and pump and treat for VOCs with GAC and groundwater monitoring for nitrate, no longer be evaluated as part of the TA-V CME.

While pump and treat remedial alternatives were demonstrated to be less effective, the analyses demonstrated that the other remedial alternatives are comparable in effectiveness and cost. Small changes in rankings will not significantly change the overall score of the remedial alternatives. The four remaining remedial alternatives are suitable for implementation at TA-V but have different strengths and weaknesses. These remedial alternatives will continue to be evaluated.

\subsection{Summary of the Preliminary Remedial Alternative Evaluation}

Based on the information presented in this Remedial Alternative Data Gaps Review, the list of remedial alternatives to be considered in data gathering activities has been revised three times, as shown in Figure 4-1. The initial list of nine was identified in the TA-V CME Work Plan (SNL/NM 2004a). This list was reduced to six as described in Section 2.0. Following the preliminary remedial alternative evaluation, the list was further reduced to four remedial alternatives that will be evaluated by conducting further studies. 


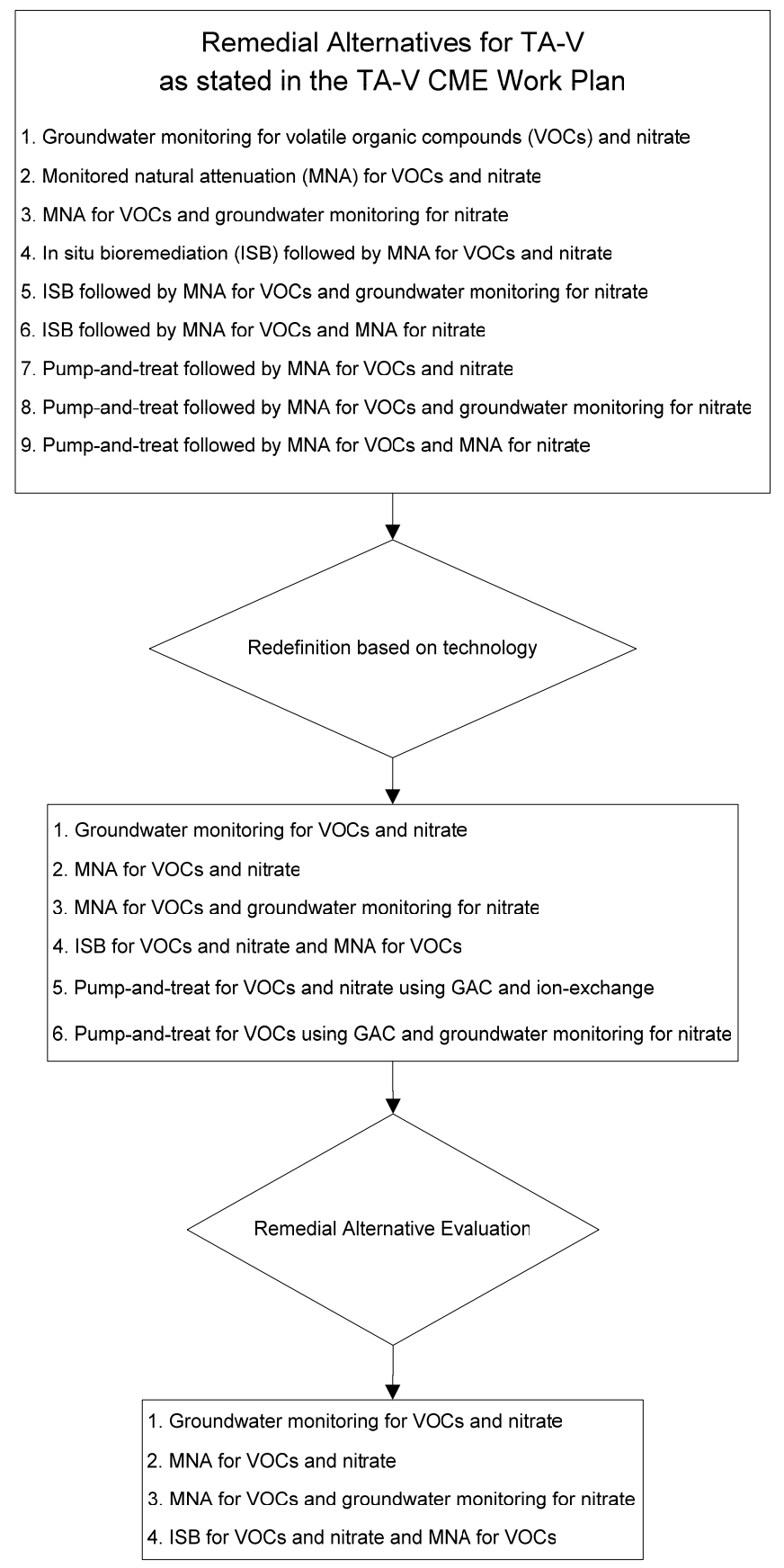

Figure 4-1. Changes in remedial alternatives for TA-V groundwater.

B-54 


\subsection{RECOMMENDATIONS FOR FURTHER STUDIES}

During the paper study, data gaps regarding individual remedial alternatives and application at TA-V have been identified. Numerical modeling, field, and laboratory studies have been identified to provide this information. A decision was made regarding the utility of performing each of these studies considering the results of the preliminary remedial alternative evaluation (Section 4). Table 5-1 presents specific activities and whether the activity will be performed. These activities correspond to stages of data gathering activities identified in the TA-V CME Work Plan (SNL/NM 2004a). Based on the information and evaluation of remedial alternative data gaps presented in this report:

- Numerical modeling will continue as planned;

- Laboratory tests will not be conducted;

- Field tests for MNA:

0 to investigate anaerobic mechanisms of degradation during natural attenuation are complete,

o to investigate an aerobic cometabolic TCE degradation mechanism at TA-V will be conducted.

- Field tests for ISB are pending based on the results of the other data gathering activities; and

- Field tests for pump and treat will not be conducted. 
Table 5-1. Recommended numerical modeling, field, and laboratory studies.

\begin{tabular}{|c|c|c|}
\hline $\begin{array}{l}\text { Stage } \\
\text { (Remedial } \\
\text { Alternative) }\end{array}$ & Activity/Purpose & Perform? \\
\hline $\begin{array}{l}\text { Numerical Modeling } \\
\text { (MNA for VOCs and } \\
\text { nitrate) } \\
\text { (MNA for VOCs and } \\
\text { groundwater monitoring } \\
\text { for nitrate) }\end{array}$ & $\begin{array}{l}\text { Numerical modeling to delineate transport of } \\
\text { contaminants, effects of dilution, and risk to } \\
\text { potential receptors. }\end{array}$ & $\begin{array}{l}\text { Yes. This study will continue as planned. The informal report } \\
\text { will be complete by November 9, } 2004 \text {. }\end{array}$ \\
\hline $\begin{array}{l}\text { Laboratory Test } \\
\text { (ISB for VOCs and nitrate } \\
\text { and MNA for VOCs) }\end{array}$ & $\begin{array}{l}\text { Laboratory microcosm tests to determine if } \\
\text { dechlorinating microbes can be induced with } \\
\text { electron donor in TA-V groundwater to degrade } \\
\text { TCE to ethene. }\end{array}$ & $\begin{array}{l}\text { No. There is sufficient evidence to show that a microbial } \\
\text { community can be induced to degrade TCE to cis-DCE. If } \\
\text { this occurs, then cis-DCE will be below the MCL. Therefore, } \\
\text { the data obtained from this study will not be worth the cost. }\end{array}$ \\
\hline $\begin{array}{l}\text { Field Scale Test } \\
\text { (MNA for VOCs and } \\
\text { nitrate) } \\
\text { (MNA for VOCs and } \\
\text { groundwater monitoring } \\
\text { for nitrate) }\end{array}$ & $\begin{array}{l}\text { Groundwater monitoring to investigate anaerobic } \\
\text { mechanisms of degradation during natural } \\
\text { attenuation. }\end{array}$ & $\begin{array}{l}\text { Completed. Results showed no evidence of biodegradation of } \\
\text { VOCs via anaerobic mechanisms or biodegradation of nitrate } \\
\text { via denitrification occurring in TA-V groundwater. }\end{array}$ \\
\hline $\begin{array}{l}\text { Field Scale Test } \\
\text { (MNA for VOCs and } \\
\text { nitrate) } \\
\text { (MNA for VOCs and } \\
\text { groundwater monitoring } \\
\text { for nitrate) }\end{array}$ & $\begin{array}{l}\text { Groundwater sampling and analyses to perform } \\
\text { enzyme probe analyses to investigate an aerobic } \\
\text { cometabolic TCE degradation mechanism. }\end{array}$ & $\begin{array}{l}\text { Yes. Groundwater samples will be sent to the analytical } \\
\text { laboratory during a future TA-V quarterly sampling event. } \\
\text { Results will be presented in an informal report by March } 1 \text {, } \\
2005 \text {. }\end{array}$ \\
\hline
\end{tabular}


Table 5-1. (continued).

\begin{tabular}{l|l|l}
\multicolumn{1}{c|}{$\begin{array}{c}\text { Stage } \\
\text { Alternative) }\end{array}$} & \multicolumn{1}{c}{ Activity/ Purpose } & \multicolumn{1}{c}{ Perform? } \\
\hline $\begin{array}{l}\text { Field Scale Test } \\
\begin{array}{l}\text { ISB for VOCs and nitrate } \\
\text { and MNA for VOCs) }\end{array}\end{array}$ & $\begin{array}{l}\text { Electron donor injection demonstration to } \\
\text { provide evidence that TCE degradation can be } \\
\text { induced by injecting aqueous electron donor, and } \\
\text { provide estimates for injection rate, injection } \\
\text { frequency, and other design estimates for full } \\
\text { scale implementation. }\end{array}$ & $\begin{array}{l}\text { Pending. Future evaluations of the ISB remedial alternative } \\
\text { will be based on the most favorable observed conditions at the } \\
\text { site concerning electron donor distribution (see Section 2.3.1). } \\
\text { If new information gathered during future tests demonstrates } \\
\text { that ISB is the preferred remedy, based on the most favorable } \\
\text { observed conditions, then an electron donor injection } \\
\text { demonstration will be performed to confirm the feasibility of } \\
\text { ISB at TA-V. If another remedial alternative is determined to } \\
\text { be the preferred alternative then the injection demonstration } \\
\text { will not be performed. }\end{array}$ \\
\hline $\begin{array}{l}\text { Field Scale Test } \\
\text { (Pump and treat for VOCs } \\
\text { and nitrate using GAC } \\
\text { and ion-exchange) } \\
\begin{array}{l}\text { (Pump and treat for VOCs } \\
\text { using GAC and } \\
\text { groundwater monitoring } \\
\text { for nitrate) }\end{array}\end{array}$ & $\begin{array}{l}\text { Aquifer tests to determine pumping rates in a } \\
\text { new extraction well for a pump and treat system } \\
\text { and provide more information on aquifer }\end{array}$ & $\begin{array}{l}\text { No. Remedial alternatives involving pump and treat } \\
\text { technology are no longer being considered. }\end{array}$ \\
\hline
\end{tabular}




\subsection{REFERENCES}

13. Alexander, M., 1967, In: “Agriculture and the Quality of Our Environment” (N.C. Brady ed.), American Association for the Advancement of Science, Washington D.C., pp. 331-342.

Formatted: Bullets and Numbering

| 14. Aziz, C.E., G. Georgiou, and G.E. Speitel, Jr., 1999, "Cometabolism of Chlorinated Solvents and Binary Chlorinated Solvent Mixtures Using M. trichosporium OB3b PP358,"

Biotechnology and Bioengineering, Vol. 65, No. 1, pp. 100-107.

| 15. Bradley, P.M. and F.H. Chapelle, 1998, "Humic Acids as Electron Acceptors for Anaerobic Microbial Oxidation of Vinyl Chloride and Dichloroethene," Applied and Environmental Microbiology, Volume 64, Number 8, pp. 3102-3105.

| 16. Bradley, P.M. and F.H. Chapelle, 2000, “Aerobic Microbial Mineralization of Dichloroethene as Sole Carbon Substrate,” Environmental Science and Technology, Volume 34, Issue 1, pp. 221-223.

17. Coleman, N. V., T. E. Mattes, J. M. Gossett, and J. C. Spain, 2002. "Biodegradation of cisDichloroethene as the Sole Carbon Source by a ß-Proteobacterium,” Applied and Environmental Microbiology, 68(6):2726-2730.

| 18. DOE 1999, Decision-Making Framework Guide for the Evaluation and Selection of Monitored Natural Attenuation Remedies at Department of Energy Sites, Department of Energy, Office of Environmental Restoration, May 1999.

| 19. DOE-ID, 2003, Monitored Natural Attenuation Remedial Action Work Plan for Test Area North Final Groundwater Remediation, Operable Unit 1-07B. DOE/ID-11055, Revision 0, U.S. Department of Energy Idaho Operations Office, June 2003.

| 20. Droste, Ronald L, 1997, “Theory and Practice of Water and Wastewater Treatment,” John Wiley \& Sons, Inc. New York. pp. 485.

| 21. EPA, 1996, "Pump-and-Treat Ground-Water Remediation: A Guide for Decision Makers and Practitioners,” EPA/625/R-95/005, July 1996, Office of Research and Development, Washington D.C., http://www.epa.gov/ORD/WebPubs/pumptreat/.

22. EPA, 1997, Ground Water Issue: Design Guidelines for Conventional Pump-and-Treat Systems. EPA/540/S-97/504, September 1997, Office of Research and Development, Washington D.C.

| 23. EPA, 1999, Use of Monitored Natural Attenuation at Superfund, RCRA Corrective Action, and Underground Storage Tank Sites, OSWER Directive 9200.4-17P, http://www.epa.gov/swerust1/directiv/d9200417.pdf.

| 24. EPA, 2001, Cost Analyses for Selected Groundwater Cleanup Projects: Pump and Treat Systems and Permeable Reactive Barriers. EPA 542-R-00-013. Solid Waste and Emergency Response. 
25. EPA, 2002, Elements for Effective Management of Operating Pump and Treat Systems. United States Environmental Protection Agency, Solid Waste and Emergency Response, Cincinnati, OH. December 2002.

| 26. Klier, N. J., R. J. West, and P. A. Donberg, 1999. "Aerobic biodegradation of dichloroethylenes in surface and subsurface soils,” Chemosophere, 38:1175-1188.

| 27. LLNL, 2000, "ERD SOP 4.17: Change of Water Phase Granular Activated Carbon-Revision 0,” LLNL Environamnetal Restoration Division (ERD) Standard Operating Procedure (SOP), Lawrence Livermore National Laboratory, California.

| 28. McCarty, P.L., 1996, "Biotic and Abiotic Transformations of Chlorinated Solvents in Ground Water,” In: Symposium on Natural Attenuation of Chlorinated Organics in Ground Water, Office of Research and Development, U.S. Environmental Protection Agency, Washington, D.C., EPA/540/R-97/504, pp. 7-11.

29. NMED, 2004, "Compliance Order on Consent Pursuant to the New Mexico Hazardous Waste Act 74-4-10: Sandia National Laboratories Consent Order,” New Mexico Environment Department, April 24, 2004.

| 30. Oldenhuis, R., R.L.J.M. Vink, D.B. Janssen, and B.Witholt, 1989, "Degradation of Chlorinated Aliphatics by Methylosinus trichosproium OB3b Expressing Soluble Methane Monoxygenase," Applied and Environmental Microbiology. Vol. 55, No. 11, pp. 2819-2826.

| 31. Semprini, L., Roberts, P.V., Hopkins, G.D., and P.L. McCarty, 1990, “A Field Evaluation of In-Situ Biodegradation of Chlorinated Ethenes: Part 2, Results of Biostimulation and Biotransformation Experiments," Ground Water, Vol. 28, No. 5, pp. 715-727.

| 32. SNL/NM, 2001, "SNL/NM Environmental Restoration Project Long-Term Monitoring Strategy for Groundwater,” Environmental Restoration Project, U.S. Department of Energy, Albuquerque Operations Office, Sandia National Laboratories/New Mexico, February 2001.

| 33. SNL/NM, 2004a, Corrective Measures Evaluation Work Plan Technical Area-V Groundwater, SAND2004-1471, April 2004, Sandia National Laboratories/New Mexico.

| 34. SNL/NM, 2004b, Current Conceptual Model of Groundwater Flow and Contaminant Transport at Sandia National Laboratories/New Mexico Technical Area-V, SAND20041470, April 2004, Sandia National Laboratories/New Mexico.

| 35. Vogel, T.M., C.S. Criddle, and P.L. McCarty, 1987, “Transformations of Halogenated Aliphatic Compounds,” Environmental Science and Technology, Vol. 21, No. 8, pp. 722-736.

| 36. Wilson, J.T. and Wilson, B. H., 1985, "Biotransformation of Trichoroethylene in Soil, Applied and Environmental Microbiology, 49: 242-243. 
APPENDIX A

REVISED TA-V SITE-SPECIFIC INFORMATION

B-60 


\section{A-1. Estimation of Specific Capacity}

Remedial alternatives involving pumping or injection would require installing new wells at TA-V. The achievable extraction or injection rates in these new wells were estimated using information from the current monitoring wells. Pumping tests, which provide information on the specific capacity and hydraulic conductivity of wells, were performed in two of the wells (TAV-MW2 and AVN-1). However, it was not known how well the hydraulic properties observed at these wells represent those of a new well, which may be constructed at another location at TA-V depending on the corrective measure.

A rough estimate of the specific capacities in each of the 13 monitoring wells was calculated from purge monitoring data during recent sampling events. Relative drawdown was calculated as the difference between an initial water level reading prior to pumping and the corresponding water level at the time being measured. Using these parameters specific drawdown was calculated for the last three measurements prior to sampling. The results are shown in Table A-1 along with calculated hydraulic conductivities from past slug tests. These results suggest that the specific capacity of AVN-1 would not be representative of the specific capacity of a new well drilled in the shallow portion of the aquifer within the vicinity of the contaminant plume. If the hydraulic properties of the performance wells (completed in the first $20 \mathrm{ft}$ of the aquifer) are considered representative of a new well, then the specific capacities would be expected to range from 0.03 to $0.86 \mathrm{gpm} / \mathrm{ft}$ of drawdown (Table A-1). Although this estimate of well specific capacities is rough, it is assumed for scoping calculations that any new wells would have a specific capacity in this range.

\section{A-2. Estimation of Transport Velocity}

Based on a reasonable range of hydraulic properties, the velocity of groundwater flow at TA-V was estimated to range from 0.5 to $168 \mathrm{ft} / \mathrm{yr}$ (SNL/NM 2004b). A velocity estimate subsequently was derived from contaminant first-arrival data. The apparent first arrival of TCE at the MCL in water from well LWDS-MW8 occurred in 2001. This well is approximately $750 \mathrm{ft}$ downgradient from the LWDS drainfield. If vertical flow in the vadose zone was relatively rapid, and water contaminated with TCE first entered the aquifer during 1963-67, the travel time through the alluvial fan/piedmont deposits to LWDS-MW8 would have been 35-39 years. An average velocity of about $20 \mathrm{ft} / \mathrm{yr}$ was derived from this travel time estimate. 
Table A-1. Summary of field data.

\begin{tabular}{|c|c|c|c|c|c|}
\hline Well & $\begin{array}{l}\text { Depth to } \\
\text { Water } \\
\text { (ft-bgs) }\end{array}$ & $\begin{array}{l}\text { Bottom of } \\
\text { Screen, } \\
\text { (ft-bgs) }\end{array}$ & $\begin{array}{l}\text { Submerged } \\
\text { Screened } \\
\text { Interval } \\
\text { (ft) }\end{array}$ & $\begin{array}{c}\text { Hydraulic } \\
\text { Conductivity } \\
\text { (ft/min) }\end{array}$ & $\begin{array}{l}\text { Specific } \\
\text { Capacity } \\
\text { (gpm/ft of } \\
\text { drawdown) }\end{array}$ \\
\hline \multicolumn{6}{|c|}{ Background Wells } \\
\hline TAV-MW3 & 535.62 & 552 & 16.38 & $2.82 * 10^{-3}$ & 0.10 \\
\hline AVN-1 & 515.12 & 590 & 20 & $\begin{array}{c}1.35^{*} 10^{-} \\
{ }^{3} / 2.66 * 10^{-2}\end{array}$ & $5.56 / 6.2$ \\
\hline AVN-2 & 512.69 & 515 & 2.31 & $1.76 * 10^{-3}$ & 0.05 \\
\hline \multicolumn{6}{|c|}{ Performance Wells } \\
\hline TAV-MW1 & 508.33 & 509.5 & 1.17 & $9.36 * 10^{-4}$ & 0.62 \\
\hline TAV-MW6 & 501.55 & 527 & 20 & $7.91 * 10^{-4}$ & 0.86 \\
\hline TAV-MW7 & 503.66 & 617 & 20 & $5.88 * 10^{-4}$ & 0.15 \\
\hline LWDS-MW1 & 493.47 & 515 & 15 & $2.62 * 10^{-5}$ & 0.03 \\
\hline TAV-MW8 & 486.81 & 511 & 20 & $5.57 * 10^{-4}$ & 0.41 \\
\hline TAV-MW9 & 490.23 & 602 & 20 & $1.05 * 10^{-4}$ & 0.03 \\
\hline TAV-MW2 & 497.56 & 517.5 & 19.94 & $\begin{array}{c}8.02 * 10^{-} \\
5 / 6.40 * 10^{-5}\end{array}$ & $0.09 / 0.03$ \\
\hline TAV-MW4 & 498.08 & 515 & 16.92 & $2.14 * 10^{-2}$ & 0.24 \\
\hline \multicolumn{6}{|c|}{ Sentry Wells } \\
\hline TAV-MW5 & 480.91 & 507 & 20 & $2.01 * 10^{-2}$ & 0.37 \\
\hline LWDS-MW2 & 483.23 & 526 & 20 & $1.65 * 10^{-3}$ & 0.15 \\
\hline \multicolumn{6}{|c|}{$\begin{array}{l}\text { a. The first or only number presented is based on slug test data. If a second number is presented, it is based on } \\
\text { pumping test data. } \\
\text { b. The first or only number presented is based on purge data gathered during recent sampling. If a second } \\
\text { number is presented, it is based on pumping test data. }\end{array}$} \\
\hline
\end{tabular}


APPENDIX B

SCOPING CALCULATIONS FOR IMPLEMENTATION OF ISB

B-63 


\section{B-1. Estimation of the Number of Wells Required for Bio-Frac ${ }^{\mathrm{TM}}$}

The number of wells that would be required for application of Bio-Frac ${ }^{\mathrm{TM}}$ to TA-V was estimated. The estimation assumes the following:

- Bio-Frac ${ }^{\mathrm{TM}}$ is generally expected to affect a radius of $15-20 \mathrm{ft}$. The fractures and chitin will be propagated along the entire thickness of contamination, which is assumed to be $20 \mathrm{ft}$.

- Assume that chitin will produce reducing conditions for 1 year. This is based on field scale chitin fracing applications at other sites.

- Assume that contaminant transport velocity is 8-20 ft/yr (SNL/NM 2004b and Appendix A), and that contaminated groundwater moving into this zone will be treated during this year.

- The area of groundwater with TCE concentrations greater than $10 \mu \mathrm{g} / \mathrm{L}$ was estimated from isopleths presented in the Current Conceptual Model for TA-V (SNL/NM 2004b). This area was estimated to be approximately 181,000 $\mathrm{ft}^{2}$.

The estimates are presented in Table B-1. As demonstrated, many wells would need to be fractured in order to meet clean-up goals in the entire zone of contamination. This would require very large capital costs compared to other ISB implementation strategies because of the number of wells and the depths where the wells would need to be completed and fractured. It is therefore considered impractical to implement this method of ISB.

Table B-1. Estimated number of wells to treat the $10 \mu \mathrm{g} / \mathrm{L}$ TCE zone of the plume with Bio-Frac ${ }^{\mathrm{TM}}$.

\begin{tabular}{c|cc}
\hline $\begin{array}{c}\text { Contaminant Transport Velocity } \\
\text { (ft/yr) }\end{array}$ & $\begin{array}{c}\text { Number of Wells } \\
\text { Assuming a 15-ft radius }\end{array}$ & $\begin{array}{c}\text { Number of Wells } \\
\text { Assuming a 20-ft radius }\end{array}$ \\
\hline 8 & 190 & 110 \\
12 & 170 & 100 \\
\hline
\end{tabular}

\section{B-2. Estimation of Electron Donor Requirements}

The goal of injections is to provide sufficient electron donor (for estimation purposes sodium lactate is considered) to the volume of contaminated aquifer in order to induce reducing conditions that will enhance denitrification of nitrate and ARD of TCE. Process knowledge of other ISB systems suggests that a target concentration of at least 1,000 mg/L lactate will achieve these conditions. In order to assess the mass of sodium lactate needed, an estimate of the volume of contaminated water was made by assuming the following:

- The thickness of the treatment zone is approximately $30 \mathrm{ft}$. The estimated depth of the contaminant zone is $20 \mathrm{ft}$. However, $30 \mathrm{ft}$ was chosen as a zone to be influenced by injections to be conservative. 
- The area of groundwater with TCE concentrations greater than $10 \mu \mathrm{g} / \mathrm{L}$ was estimated from isopleths presented in the Current Conceptual Model for TA-V (SNL/NM 2004b). This area was estimated to be approximately $181,000 \mathrm{ft}^{2}$.

- Effective porosity is 25\% (SNL/NM 2004b).

The volume of groundwater was calculated and the mass of lactate needed to achieve a target concentration of $1,000 \mathrm{mg} / \mathrm{L}$ in this volume was estimated to be $106,000 \mathrm{lb}$. Sodium lactate is generally purchased in 55-gal drums of $60 \%$ solution. Therefore, an estimate of the number of sodium lactate drums necessary to inject into the aquifer is approximately 293 drums.

\section{B-3. Estimation of the Number of Wells Required for Sodium Lactate Injection}

Estimates of the number of wells needed to inject a sufficient volume to influence the entire contaminant area (with TCE concentrations greater than $10 \mu \mathrm{g} / \mathrm{L}$ ) were made using the following assumptions:

- An injection will likely only need to occur one or two times and injection events will occur over several days. During this several day injection event, injection may occur continuously or it may be decided to pulse the injection by injecting over shorter periods of time for several days. However, if pulsing occurs over several days then the rapid utilization of electron donor should be considered when determining the space of time between injection pulses.

- It is assumed that advection and dispersion will effect distribution of sodium lactate. The groundwater velocity ranges from 0.5 to $168 \mathrm{ft} / \mathrm{yr}$ (SNL/NM 2004b).

- The specific capacity of injection wells range from 0.03 to $0.86 \mathrm{gpm} / \mathrm{ft}$ of drawdown (Appendix A), and it is assumed that up to $400 \mathrm{ft}$ of water will be allowed to build in the well headspace. This increase in pressure will allow for a faster injection rate.

Table B-2 summarizes estimated injection times and demonstrates that the rate at which the new injection well will accept the injection is the limiting factor. The estimates demonstrate that distribution of electron donor may be reasonable if the well or wells will accept the injection at a sufficient rate. However, if the well will not accept the injection at a sufficient rate, implementation of ISB will require an excessively long injection. The achievable injection rate is a remaining data gap, however the CME will continue based on the most favorable conditions for electron donor distribution observed. If ISB is chosen as a preferred remedy then a lactate injection demonstration will need to be performed to confirm the feasibility of ISB.

Table B-2. Estimated injection times.

\begin{tabular}{l|c|c|c}
\hline \multirow{2}{*}{} & \multicolumn{3}{|c}{ Number of wells } \\
\cline { 2 - 4 } & $\mathbf{1}$ & $\mathbf{2}$ & $\mathbf{3}$ \\
\hline $\begin{array}{l}\text { Estimated injection time } \\
\text { (specific capacity is 0.03 gpm/ft of drawdown) })^{1}\end{array}$ & $\begin{array}{c}2800-3200 \\
\text { hours } \\
100-110 \\
\text { hours }\end{array}$ & $\begin{array}{c}1890-2230 \\
\text { hours }\end{array}$ & $\begin{array}{c}1440-1730 \\
\text { hours }\end{array}$ \\
$\begin{array}{l}\text { Estimated injection time } \\
\text { (specific capacity is 0.86 gpm/ft of drawdown) }\end{array}$ & $\begin{array}{c}1 \\
\text { hours }\end{array}$ & 60-70 hours \\
\hline
\end{tabular}

1. A range of times are presented due to variability in groundwater velocity estimates. 
APPENDIX C

SCOPING ESTIMATES OF OPERATIONS AND TIMEFRAME FOR PUMP AND TREAT

B-66 


\section{C-1. Capture Zone Analyses}

Equation 1 describes the method used to calculate the capture zone width (W). This method is adopted from Elements for Effective Management of Operating Pump and Treat Systems

(EPA 2002).

$W=\frac{Q}{C \times B \times K \times i}$

where:

$$
\begin{array}{lll}
\mathrm{Q} & = & \text { extraction rate }(\mathrm{gpm}) \\
\mathrm{C} & = & \text { volume conversion factor }\left(7.481 \mathrm{gal} / \mathrm{ft}^{3}\right) \\
\mathrm{B} & = & \text { saturated thickness }(\mathrm{ft}) \\
\mathrm{K} & = & \text { hydraulic conductivity }(\mathrm{ft} / \mathrm{min}) \\
\mathrm{i} & = & \text { hydraulic gradient }(\mathrm{ft} / \mathrm{ft}) .
\end{array}
$$

This method assumes the following:

1. The horizontal hydraulic conductivity $\left(\mathrm{K}_{\mathrm{h}}\right)$ ranges from $10^{-4}$ to $10^{-5} \mathrm{ft} / \mathrm{min}$ (SNL/NM 2004b).

2. The vertical hydraulic conductivity $\left(\mathrm{K}_{\mathrm{v}}\right)$ is $1 / 10$ to $1 / 100$ of the vertical hydraulic conductivity and the well is assumed to completely penetrate the aquifer (SNL/NM 2004b). The hydraulic properties of the aquifer suggest that flow to the well is radial because $K_{h}$ is much greater than $K_{v}$.

3. The screened interval is $30 \mathrm{ft}$ and the maximum drawdown is $25 \mathrm{ft}$. This thickness was chosen to be conservative. It was assumed that at least $5 \mathrm{ft}$. of water should remain in the well during pumping.

4. Effective porosity is $25 \%$ (SNL/NM 2004b).

5. The horizontal hydraulic gradient (i) ranges from 0.003 to $0.009 \mathrm{ft} / \mathrm{ft}$ (SNL/NM 2004b).

6. The aquifer is homogenous and isotropic. This assumption is necessary for this approach, however the aquifer may not be homogenous or isotropic within the capture zone.

7. The well is pumped continuously.

8. There is no recharge (SNL/NM 2004b). 
As is shown in Table C-1, the estimated capture zone widths are very large compared to the width of the contaminant plume. It is concluded from these calculations that capturing the contaminant plume as it is transported across a downgradient location will not be a significant challenge. A more pertinent question may be: Is capturing the contaminant plume in this way an effective means of remediation? There is no contaminant source, and it may take several years for the plume to move past this downgradient capture zone due to slow contaminant transport velocities (8-20 ft/yr). Therefore, it is concluded that this approach to pump and treat remediation is not an effective approach when compared to other remedial alternatives.

Table C-1. Capture zone width calculation.

\begin{tabular}{ccc}
\hline & \multicolumn{3}{c}{ Capture Zone Width (W), miles } \\
& Max Specific capacity and $\mathbf{K}=\mathbf{1 0}^{-\mathbf{4}}$ & Min. Specific Capacity and $\mathbf{K}=\mathbf{1 0}^{-\mathbf{5}}$ \\
\hline $\mathrm{i}=0.003$ & 2.1 & 633.0 \\
$\mathrm{i}=0.009$ & 0.7 & 211.0 \\
\hline
\end{tabular}

\section{C-2. Estimation of Pore Volume and Pumping}

The range of estimated treatment times discussed in Section 2.4.3 were based on the assumed number of pore volumes that needed to be pumped from the contaminated aquifer zone to remove the entire mass of aqueous and sorbed TCE. The calculated times and flows were estimated using the following assumptions:

- Effective porosity is 25\% (SNL/NM 2004b).

- The area of groundwater with TCE concentrations greater than $10 \mu \mathrm{g} / \mathrm{L}$ was estimated from isopleths presented in the Current Conceptual Model for TA-V (SNL/NM 2004b). This area was estimated to be $181,000 \mathrm{ft}^{2}$.

- The screened interval is $30 \mathrm{ft}$ and the maximum drawdown is $25 \mathrm{ft}$. This thickness was chosen to be conservative. It was assumed that at least $5 \mathrm{ft}$. of water should remain in the well casing during pumping.

- Specific capacities ranged from 0.03 to $0.86 \mathrm{gpm} / \mathrm{ft}$ of drawdown (see Appendix A).

- The well(s) will be pumped continuously for the entire period, and effects of regional water level decline were neglected.

- Between 10 and 100 pore volumes need to be pumped (EPA 1997). 
APPENDIX D

TREATMENT AND DISPOSAL OPTIONS FOR PUMP AND TREAT

B-69 
This appendix provides details on ex-situ treatment and treated water disposal options that are being considered for implementation of pump and treat. These technologies or a combination of these technologies may be applied if a remedial alternative involving pump and treat is chosen as the preferred remedial alternative for TA-V groundwater. The following sections provide details on two treatment options including granular activated carbon (GAC), and ion exchange and two disposal options including disposal to the sanitary sewer and on-site disposal.

\section{D-1. Granular Activated Carbon Treatment for VOCs}

This treatment option uses sorption to GAC to treat contaminated groundwater. The technology effectiveness is well characterized for treatment of VOCs, and is an option for treating the COCs, TCE and PCE. GAC treatment is not effective at removing nitrate. A treatment design is given here to provide estimates on the operating requirements. However, if the technology were implemented given the wide range of results presented here the system would need to be designed based on more accurate data.

\section{Design}

The treatment unit will consist of a series of three 55-gallon drums of GAC (Figure D-1). The series of drums may be connected such that the down hole pumps will provide sufficient head for flow through the system. This design will require the following:

- A sea-van to house the treatment units. The sea-van will need to be equipped with a door, ventilation, electricity, and plumbing to the COA sewer system or on-site disposal system (i.e., injection well).

- Three 55-gal drums of GAC.

- A framework to support a tiered series of drums.

- Piping, fittings, and plumbing equipment. This should include a flow meter on the effluent line and sampling ports on all influent lines (coming from the wells), prior to each GAC drum, and on the effluent line.

Scoping calculations have been performed to estimate treatment unit size, design, and operation needs. Assumptions used in these calculations include:

- Constant influent TCE and cis-DCE concentrations are assumed. The concentrations are the maximum observed concentrations divided by the number of pore volumes that will be flushed. However, it is likely that GAC will need to be replaced more often during the first years of operation.

- Literature values for isotherm constants were used (LLNL, 2000).

- The GAC density was assumed considering literature values (Droste 1997) and manufacturers specifications. 


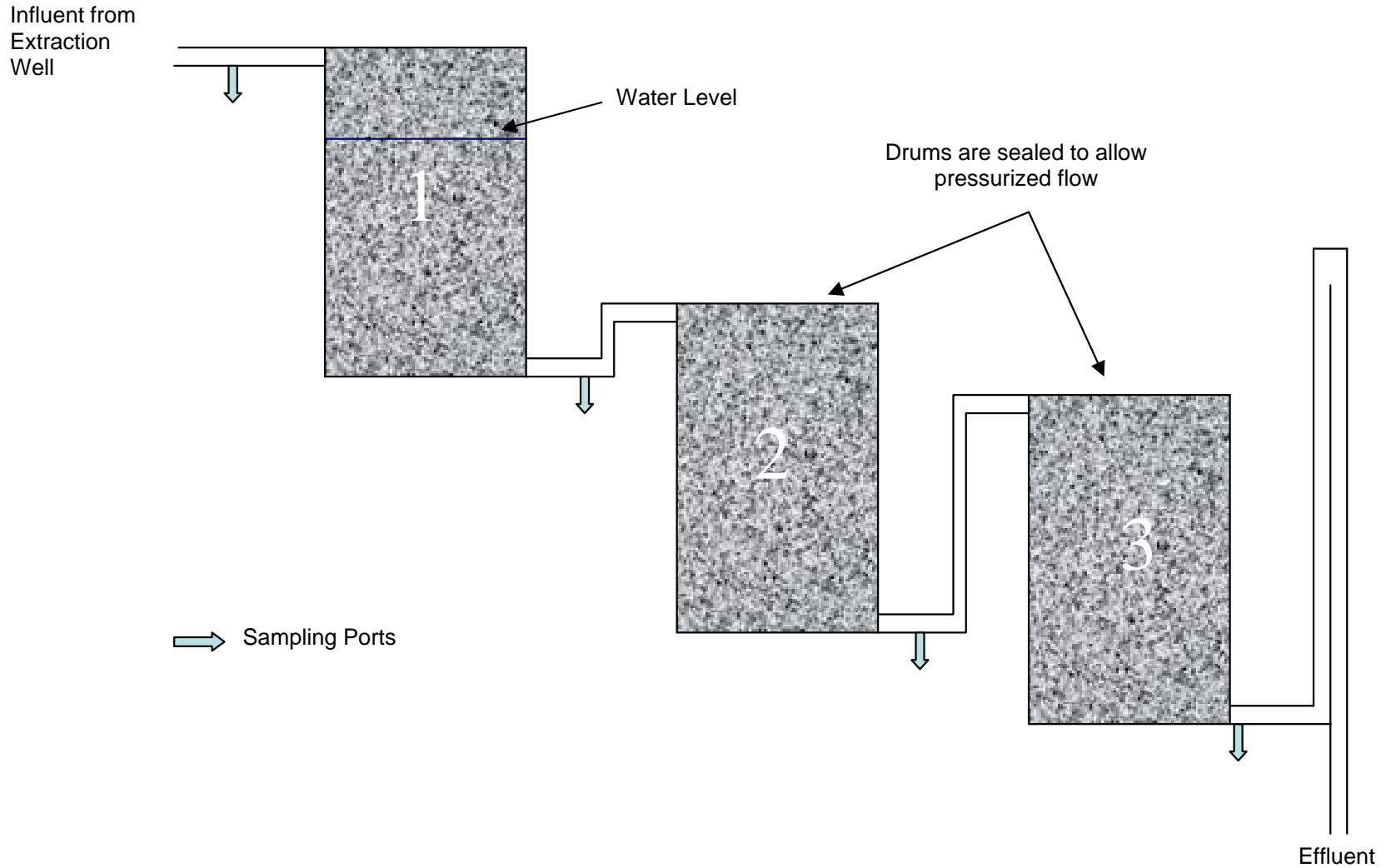

Figure D-1. Schematic of GAC treatment unit. 
Associated uncertainties with these estimates must be considered when using the estimates presented in Table D-1. There is also indication that competing adsorbates may limit the useful life of the GAC. Other VOCs have been detected as well as dissolved organic carbon (DOC). Therefore, a large safety factor (5) has been applied to the calculations to account for these effects.

Table D-1. Summary of calculations.

\begin{tabular}{l|c|c|c|c}
\hline & \multicolumn{2}{|c|}{$\begin{array}{c}\text { Operation Duration } \\
\text { (years) }\end{array}$} & \multicolumn{2}{c}{$\begin{array}{c}\text { GAC Replacement Rate } \\
\text { (days) }\end{array}$} \\
\hline & $\mathbf{1}$ & $\mathbf{2}$ & $\mathbf{1}$ & $\mathbf{2}$ \\
\hline 10 pore volumes & $9-260$ & $5-130$ & $40-1200$ & $20-600$ \\
100 pore volumes & $90-2600$ & $45-1300$ & $110-3200$ & $60-1600$ \\
\hline
\end{tabular}

Operations will include regular monitoring of the influent, two sampling ports between the barrels, and effluent, and when necessary disposal and replacement of GAC. If VOCs are detected in the sampling port between the second and third GAC container, then the system will be recharged with fresh GAC. This will likely be done by removing the GAC in the $1^{\text {st }}$ container (the container attached to the influent line), and rotating the second container to the first place, the third container to the second place, and placing the fresh GAC in the third place (Figure D-1).

\section{Advantages and Disadvantages Compared to Other Treatment Options}

Advantages of implementing this treatment design include:

- Requires little maintenance,

- The risk of failure is small, considering the well-characterized effectiveness of activated carbon at removing VOCs, and

- The activated carbon is capable of removing low concentrations of VOCs.

Disadvantages include:

- Will not remove nitrate,

- A solid waste is produced, and

- The effect of competing sorbates on useful life of the GAC is unknown and will need to be characterized during remedial alternative implementation.

\section{D-2. Ion Exchange Unit for Nitrate Removal}

This option uses ion exchange to remove nitrate from the water. The option is not effective for treatment of VOCs, and will need to be applied in a treatment train where VOCs have been removed previously. A treatment design is given here to provide estimates on the operating requirements. However, if the technology were implemented given the wide range of results presented here the system would likely be designed larger or smaller depending on the flow rate. 


\section{Design}

The technology uses anion exchange resins to remove nitrates. The resins are periodically recharged using a salt solution. Fouling of the resins is possible due to biological activity, however if ion exchange is to be used it will follow treatment with GAC, which will remove organic compounds. The system used to calculate the results presented is a $1-\mathrm{ft}^{3}$ system. If flow into the system is high, the system volume will likely be increased.

Qualities of the groundwater at TA-V that may effect implementation of this technology include the presence of sulfate and hardness. Sulfate in the groundwater will compete with nitrate on the anion exchange resin. An average sulfate concentration of $40 \mathrm{mg} / \mathrm{L}$ was used in scoping calculations for which the results are presented in Table D-2. A safety factor of three was applied in these calculations and there is significant uncertainty associated with these estimates. However, the estimated operating parameters should provide initial estimates of ion exchange operating needs. Each regeneration will require flushing the resins with several volumes of salt solution. Hardness in the groundwater may interfere with the nitrate removal. Hardness in the groundwater at TA-V is generally greater than $100 \mathrm{mg} / \mathrm{L}$ as calcium carbonate, and it may be necessary to remove this hardness.

Table D-2. Estimated parameters for operating an ion exchange unit.

\begin{tabular}{l|c|c|c|c}
\hline & \multicolumn{2}{|c|}{$\begin{array}{c}\text { Operation Duration } \\
\text { (years) }\end{array}$} & \multicolumn{2}{c}{$\begin{array}{c}\text { Regeneration Rate } \\
\text { (hours) }\end{array}$} \\
\hline & $\mathbf{1}$ & $\mathbf{2}$ & $\mathbf{1}$ & $\mathbf{2}$ \\
\hline 10 pore volumes & $9-260$ & $5-130$ & $0.2-6$ & $0.1-3$ \\
100 pore volumes & $90-2,600$ & $50-1,300$ & & \\
\hline
\end{tabular}

Advantages and Disadvantages Compared to Other Treatment Options

Advantages of implementing this treatment design include:

- Low risk of failure and expected to remove nitrates up to $80 \%$.

Disadvantages include:

- Hardness is present in the groundwater at levels greater than $100 \mathrm{mg} / \mathrm{L}$ as $\mathrm{CaCO}_{3}$, which will likely interfere with effective operation of an ion exchange unit and may require a separate hardness removal step,

- Produces a concentrated nitrate brine waste stream, and

- Regeneration is frequent and may require significant maintenance. 


\section{D-3. Disposal of Water to the Sanitary Sewer}

This is a disposal option that may be available for disposal of water contaminated with nitrate and water that has been treated for all COCs. If only VOCs are treated, then the water will contain concentrations of nitrate that will likely remain less than $20 \mathrm{mg} \mathrm{NO} 3$ as nitrogen/L. Permission must be obtained to dispose of this wastewater, and monitoring and other precautions must be taken to ensure VOCs and other contaminants are not introduced into the waste-stream. This may involve frequent monitoring at the GAC treatment unit effluent and temporary containment of the waste in a large tank prior to disposal.

\section{Advantages and Disadvantages Compared to Other Disposal Options}

Advantages of implementing this option include:

- If only VOCs are treated on-site, then this option will still remove both contaminants from the aquifer and provide a means of disposing of the treated water, and

- No additional waste-streams are produced.

Disadvantages of implementing this option include:

- Permission must be obtained from the City of Albuquerque, and

- Monitoring may be more frequent.

\section{D-4. On-Site Disposal of Treated Water}

This option may be applied to water that has been treated for all COCs and water that has only been treated for VOCs. The most likely on-site disposal method is injection to the aquifer. This option will require drilling a well or designating a well for injection of treated water. Other on-site disposal methods may include infiltration ponds and disposal to the vadose zone.

\section{Advantages and Disadvantages Compared to Other Disposal Options}

Advantages of implementing this option include:

- May replenish the aquifer, where the regional water-level decline is already fast.

Disadvantages of implementing this option include:

- If only VOCs are treated on-site, then this option will not remove nitrate from the aquifer,

- If only VOCs are treated on-site, then permission to inject nitrate contaminated water must be obtained, and

- This option will likely require drilling another well. 
This Page Intentionally Left Blank

C-75 
Attachment C

Evaluation of Contaminant Transport in Groundwater

C-1 
This Page Intentionally Left Blank

C-2 


\title{
Evaluation of Contaminant Transport in Technical Area-V Groundwater at Sandia National Laboratories/New Mexico
}

\author{
March 2005
}

Prepared by

Sandia National Laboratories

Albuquerque, New Mexico 87185 and Livermore, California 94550

Sandia is a multiprogram laboratory operated by Sandia Corporation,

a Lockheed Martin Company, for the United States Department of Energy's

National Nuclear Security Administration under Contract DE-AC04-94AL85000.

Approved for public release; further dissemination unlimited.

\section{i. Sandia National Laboratories}




\begin{abstract}
The Corrective Measures Evaluation Work Plan Technical Area-V Groundwater identified four stages of studies that would be conducted to investigate data gaps in the evaluation of remedial alternatives and to calculate design parameters for corrective measure implementation. This informal report presents results of the second-stage numerical groundwater modeling evaluations to determine the fate of contaminants, effects of dilution, and order-of-magnitude concentration changes at downgradient receptors.
\end{abstract}

A United States Geological Survey (USGS) regional groundwater model was initially adapted to conduct this evaluation of the fate of contaminants downgradient from Technical Area-V (TA-V). Although this regional groundwater model adequately permits assessment of largescale stresses on the aquifer system and provides evaluation of Sandia National Laboratories/New Mexico water resources within the context of the Albuquerque Basin, the model scale and individual cell size were too large for the scale of this TA-V dilution evaluation. Further analysis was required to adequately evaluate the dilution factor along a flowpath from $\mathrm{TA}-\mathrm{V}$ to existing and potential pumping centers.

A simple cross-sectional modeling approach, incorporating hydraulic properties from the adapted USGS Albuquerque Basin model, was used to refine the evaluation of dilution down the flow path. The cross-sectional modeling strategy was to develop a simplified representation of cross-sectional flow along the groundwater flowpath that included TA-V. Relative concentrations of a solute were then simulated along that flowpath. The study incorporated two cross-sectional models. The first model (alluvial-fan section) represented westward groundwater flow in the alluvial fan lithofacies beneath TA-V. The second model (ancestral Rio Grande [ARG] section) represented northward flow within the ARG toward City of Albuquerque and Kirtland production wells.

Simulated contaminant concentrations were diluted by a factor of 5 within the 10,000-ft alluvial-fan section downgradient from the TA-V source area. The contaminant travel time through the alluvial-fan lithofacies, based on the hydraulic conductivity of $8 \mathrm{ft} /$ day, is estimated to be at least 150 years. Peak concentration breakthrough (approximately 20\% of initial concentration) into the ARG deposits occurs approximately 180 years after release at TA-V. The contaminant pulse that was introduced during the 5-year disposal time at TA-V was attenuated and simulated. The model predicted contaminant breakthrough to occur over an interval of approximately 45 years at the downgradient end of the section.

The ARG cross-sectional model results indicate that contaminant concentrations would be diluted by approximately four orders of magnitude as they are leached into the ARG lithofacies. A conservative estimate of dilution may approach four orders of magnitude along the flowpath. The minimum travel time of groundwater and conservative solutes from TA-V to the Ridgecrest well field is estimated to be 230 years under the assumptions of the model. Based on this conservative analysis and known concentrations in the TCE plume at TA-V, contaminant concentrations would be less than current instrument detection limits. Further reduction in concentration is expected from contaminant degradation, sorption, and lateral dispersion. 


\section{CONTENTS}

ABSTRACT

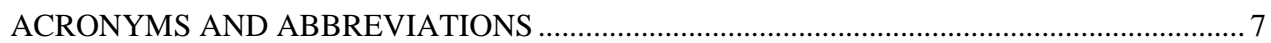

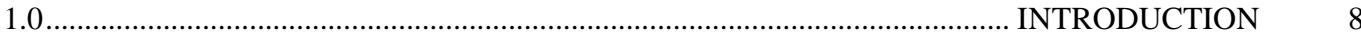

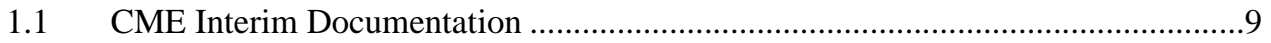

$1.2 \quad$ Purpose and Scope of Numerical Modeling Studies.................................................9

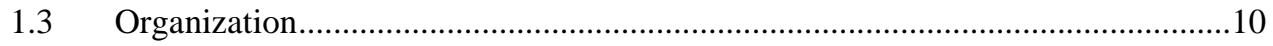

2.0 ...........................CONCEPTUAL MODEL OF FLOW AND CONTAMINANT TRANSPORT 11

2.1 Regional Geohydrologic Setting ........................................................................11

2.1.1 Large-Scale Geologic Features 11

2.1.2 Hydrostratigraphic Framework 13

2.1.3 Regional Recharge 13

2.1.4 Regional Discharge 13

2.1.5 Regional Groundwater Flow 13

2.2 Hydrologic Conditions at TA-V 15

2.2.1 Hydrostratigraphic Units 15

2.2.2 Groundwater Flow at TA-V 15

2.2.3 Contaminant Transport in Groundwater at TA-V 18

2.2.4 Summary of the Conceptual Model of Groundwater Flow and

Contaminant Transport at TA-V 23

3.0.................... NUMERICAL SIMULATION OF CONTAMINANT FATE AND TRANSPORT

3.1 Regional Numerical Model.

3.1.1 Regional USGS Groundwater Model Structure

24

3.1.2 Dilution Study Strategy 26

3.1.3 Model Adaptations to SNL/NM 26

3.1.4 Model Results 27

3.1.5 Implications 28

3.2 Simplified Cross-Sectional Analysis

3.2.1 Cross-Sectional Groundwater Flow through the Alluvial-Fan Lithofacies beneath TA-V 28

3.2.2 Cross-Sectional Groundwater Flow toward Municipal Pumping Centers through the Ancestral Rio Grande Lithofacies West of TA-V 33

C-5 
3.2.3 Cross-Sectional Groundwater Flow toward a Potential Production Well

Field at Mesa del Sol 35

4.0SUMMARY OF NUMERICAL ANALYSES OF GROUNDWATER FLOW AND CONTAMINANT

TRANSPORT 37

5.0 .REFERENCES CITED

\section{FIGURES}

1-1. Illustration of the staged process of data gathering activities and production of subsequent reports.

2-1. Location of the Rio Grande Rift, Albuquerque Basin, Select Precambrian Lineaments (in red), Kirtland Air Force Base (KAFB), and SNL/NM TA-V.................................... 12

2-2. Configuration of the regional groundwater surface in the Albuquerque Basin, 1994-1995.

2-3. Geophysical-log correlation Section A-A', extending from west to east across SNL/NM TA-V.

2-4. Subregional potentiometric surface in the vicinity of TA-V, 2000 ............................... 17

2-5. Location of wastewater disposal facilities and the TCE plume within the TA-V area......... 19

2-6. TCE concentrations over time at selected TA-V wells..................................................... 22

3-1. USGS regional model grid and recharge cells, Albuquerque Basin................................... 25

3-2. Subregional 2000 potentiometric surface for SNL and approximate location of simplified alluvial-fan and ARG groundwater cross-sections. ..................................................... 29

3-3. Simulated distribution of a contaminant within the simplified east-west alluvial-fan cross-sectional groundwater flow model after 40 years (10X vertical exaggeration)......... 32

3-4. Simulated distribution of a contaminant within the simplified south-north ARG cross-sectional groundwater flow model after 45 years of injection (10X vertical

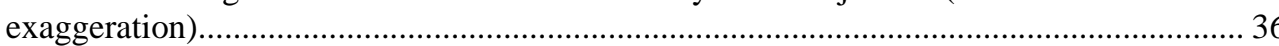

4-1. Relative peak contaminant concentrations along the alluvial-fan and ARG flowpaths from $\mathrm{TA}-\mathrm{V}$ to the Ridgecrest well field 


\section{ACRONYMS AND ABBREVIATIONS}

\begin{tabular}{|c|c|}
\hline ARG & ancestral Rio Grande \\
\hline $\mathrm{AVN}$ & Area V North \\
\hline CME & Corrective Measures Evaluation \\
\hline COA & City of Albuquerque \\
\hline COC & contaminant of concern \\
\hline COOC & Compliance Order on Consent \\
\hline $\mathrm{ft}$ & foot or feet \\
\hline $\mathrm{ft} / \mathrm{yr}$ & feet per year \\
\hline gal & gallon \\
\hline KAFB & Kirtland Air Force Base \\
\hline $\mathrm{km}$ & kilometer \\
\hline LWDS & Liquid Waste Disposal System \\
\hline MCL & maximum contaminant level \\
\hline NMED & New Mexico Environmental Department \\
\hline PCE & tetrachloroethene \\
\hline SNL/NM & Sandia National Laboratories/ New Mexico \\
\hline SWMU & Solid Waste Management Unit \\
\hline TA-V & Technical Area V \\
\hline TCE & trichloroethene \\
\hline USGS & United States Geological Survey \\
\hline
\end{tabular}




\subsection{INTRODUCTION}

The Corrective Measures Evaluation Work Plan Technical Area-V Groundwater (Hall, Dettmers, and Lebow 2004), referred to in this report as the Technical Area-V (TA-V) Corrective Measures Evaluation (CME) Work Plan, was prepared as directed by the Compliance Order on Consent (COOC) issued by the New Mexico Environment Department (NMED) (NMED 2004). The TA-V CME Work Plan outlines a process to evaluate remedial alternatives to identify a corrective measure for the Sandia National Laboratories/New Mexico (SNL/NM) TA-V groundwater. As part of this process, specific data gaps were identified to evaluate potential remedial alternatives.

The TA-V CME Work Plan defined four stages of studies to be conducted to investigate those data gaps. The paper-study stage (Stage 1) consists of a data gaps review of each remedial alternative within the context of the threshold criteria and remedial alternative evaluation criteria discussed in the CME Work Plan. Stage 2 consists of a numerical modeling evaluation of the fate and transport of contaminants in groundwater moving from TA-V toward downgradient receptors. This stage is intended to assist in consideration of remedial alternatives that remained after the paper-stage technical evaluation. Stages 3 and 4 consist of laboratory and field-scale studies to provide specific information required for each of the remedial alternatives. Results of the four stages will be used to evaluate each remedial alternative and calculate design parameters for corrective measure implementation.

Two proposed numerical modeling studies were identified in the Current Conceptual Model of Groundwater Flow and Contaminant Transport at Sandia National Laboratories/New Mexico Technical Area V (Orr and Dettmers 2004), referred to in this report as the TA-V Current Conceptual Model, and were further described in the TA-V CME Work Plan (Hall, Dettmers, and Lebow 2004), as follows:

- Study 1. Numerical modeling studies have been conducted to evaluate capture zones for production wells located north of TA-V (SNL/NM 2001). These capture zone studies indicate that travel times to production wells may be as long as 100 years. However, contaminant concentrations along the flow path were not estimated. Evaluation of contaminant breakthrough at different locations along the flow path (including the sharp change in flow direction associated with the distribution of ancestral Rio Grande [ARG] deposits) will be performed to determine the fate of contaminants, effects of dilution, and order-of-magnitude concentration changes at downgradient receptors. This evaluation of the fate of contaminants downgradient from $\mathrm{TA}-\mathrm{V}$ will utilize existing numerical simulators.

- Study 2. Municipal pumpage from the COA Ridgecrest well field has greatly modified the direction of flow in the aquifer to the west of TA-V. One long-term water-use scenario may include discontinuing or reducing pumping from this well field. A numerical modeling study of this scenario will be conducted to show particle tracking of contaminants without the influence, or a reduced influence, of pumpage from the COA Ridgecrest well field. A second long-term water use scenario that will be considered is the possibility of additional municipal withdrawals from a pumping center located west of TA-V in the Mesa del Sol area. Results of contaminant transport will help determine a timeframe and magnitude of risk reduction to downgradient receptors. 
The use of existing numerical simulators demonstrated that further work was required to complete Study-1 and Study-2 activities. Subsequently, a set of cross-sectional models was developed to define the effect of dilution on downgradient concentrations of contaminants for the scenarios identified in both studies.

\subsection{CME Interim Documentation}

As the four stages of data gathering activities are carried out, individual informal reports will be created to document the results. These reports will be prepared by the CME implementation team to be reviewed by the project leader, technical peer review panel, and technical support personnel (project organizational structure is discussed in Section 7.2 of the TA-V CME Work Plan) (SNL/NM 2004). The purpose of the informal reports includes:

- Reporting results and interpretation of results to the project leader, technical peer review panel and technical support personnel,

- Documenting decisions made during the CME process and documenting the results of the three stages of data gathering, and

- $\quad$ Providing supporting information for the CME Report.

Figure 1-1 illustrates the staged process of data gathering activities and the subsequent reports.

\subsection{Purpose and Scope of Numerical Modeling Studies}

Contaminant dilution downgradient from TA-V is an important factor in consideration of the effectiveness of different remedial alternatives. The Stage-2 numerical modeling evaluation was intended to fill data gaps associated with the fate and transport of contaminants as they move toward downgradient receptors. The evaluation also was intended to assist in further consideration of those remedies that passed the evaluation following the paper studies remedial alternatives data-gap review.

This document presents a description of Stage-2 numerical modeling studies, including discussion of the numerical representation of conceptual model elements. The document also describes modeling results and implications on contaminant fate and transport toward potential downgradient receptors. 


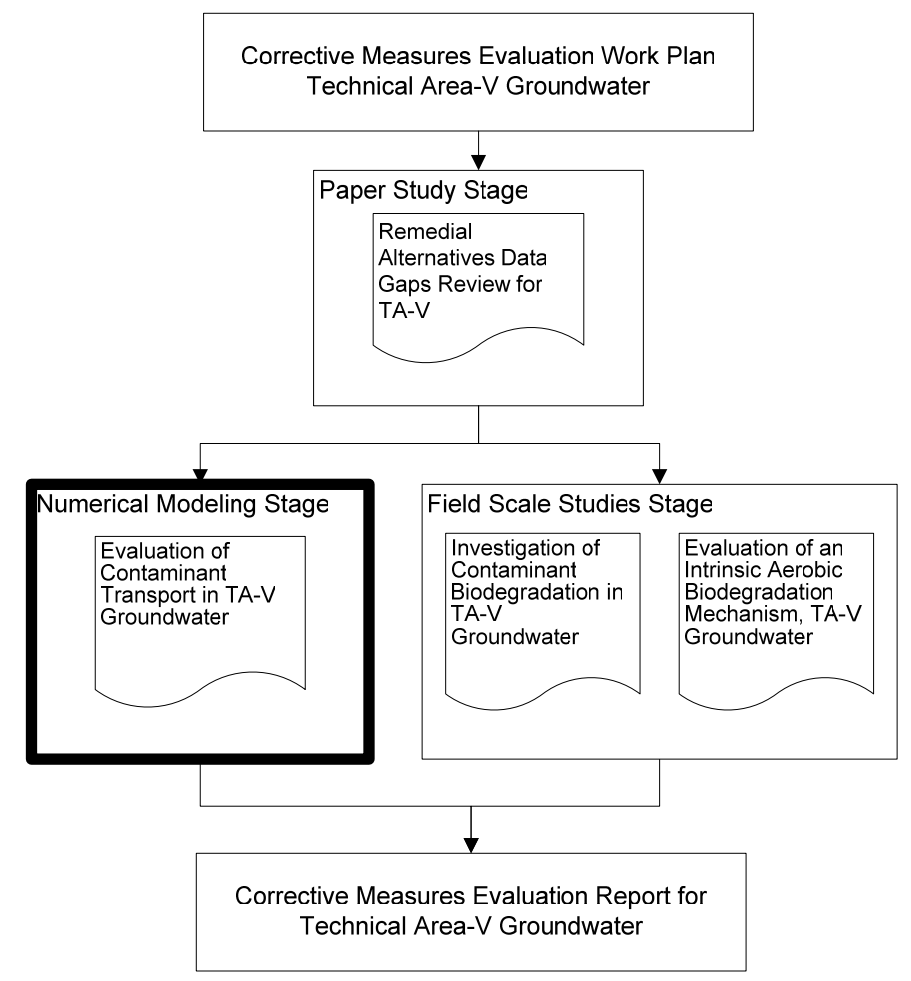

Figure 1-1. Illustration of the staged process of data gathering activities including numerical modeling (outlined in bold) and subsequent reports.

\subsection{Organization}

This Stage-2 numerical modeling paper for TA-V is organized into the following sections:

- Section 2 summarizes the conceptual model for groundwater flow and contaminant transport at SNL/NM TA-V.

- Section 3 presents a description of numerical models of flow and contaminant transport used to evaluate dilution of contaminants in groundwater at TA-V. This numerical model discussion includes:

o Description of the existing regional model, adapted from the United States Geological Survey (USGS), modeling strategy for the dilution study, and modeling results.

o Description of a numerical analysis of dilution using a set of simplified cross-sectional flow and transport models.

o Discussion of implications.

- Section 4 presents a summary and implications of Stage-2 numerical modeling studies in evaluation of remedial alternatives for TA-V. 


\subsection{CONCEPTUAL MODEL OF FLOW AND CONTAMINANT TRANSPORT}

Subsequent sections summarize the present conceptual model of groundwater flow and contaminant transport at TA-V, as described in the TA-V Current Conceptual Model (Orr and Dettmers 2004). The sections also present additional information based on recent data. The sections include a discussion about the regional geohydrologic setting and hydrologic conditions in the area of TA-V.

\subsection{Regional Geohydrologic Setting}

SNL/NM TA-V is located within the Albuquerque Basin of the Rio Grande Rift in north-central New Mexico (Figure 2-1). The geologic and hydrologic conditions of the Albuquerque Basin form the regional context of local groundwater flow and contaminant migration at TA-V.

This section briefly describes the regional geohydrologic setting (as defined by large-scale geologic features), the hydrostratigraphic framework of the Albuquerque Basin and the basin-fill sedimentary units of the Santa Fe Group, regional recharge and discharge, and configuration of regional groundwater flow.

\subsubsection{Large-Scale Geologic Features}

The Rio Grande Rift is a relatively continuous regional structural zone that extends north from Mexico, across New Mexico, and into southern Colorado. Formation of this feature began 25 million years ago in northern Mexico when tectonic forces began to pull apart the brittle upper crust of the North American Plate and continued toward the north.

The Rio Grande Rift is marked by a series of sediment-filled structural basins and adjoining uplifted mountain ranges (Figure 2-1). One of these basins, the Albuquerque Basin (also known as the Middle Rio Grande Basin), covers about 3,060 square miles in central New Mexico and extends from Cochiti Reservoir on the north to San Acacia, New Mexico on the south. The Albuquerque Basin includes the COA and parts of Santa Fe, Sandoval, Bernalillo, Valencia, Socorro, Torrance, and Cibola Counties.

The major fault systems that bound the Albuquerque Basin have dominated the development of geologic and hydrologic features within the basin. These fault systems consist of sets of subparallel, high-angle, large-displacement normal faults that separate the subsided basin from adjoining uplifted mountain blocks. Fault blocks on the inside of the rift zone typically have dropped down relative to uplifted fault blocks on the eastern and western edges of the rift.

Rift zone faulting has controlled sedimentary deposition within the Albuquerque Basin throughout its history. Continued movement along faults has modified local drainage systems and formed topographically high areas that provided a ready source of newly eroded sediments. Fault offsets brought Santa Fe Group sediments into contact with upfaulted Paleozic rocks along the basin margins. Because active faulting was occurring at the same time as sedimentary deposition, faults also have offset stratigraphic units within the Santa Fe Group. Fault zones also have served as conduits for vertical groundwater flow and as regional hydrologic boundaries to the Santa Fe Group aquifer. 


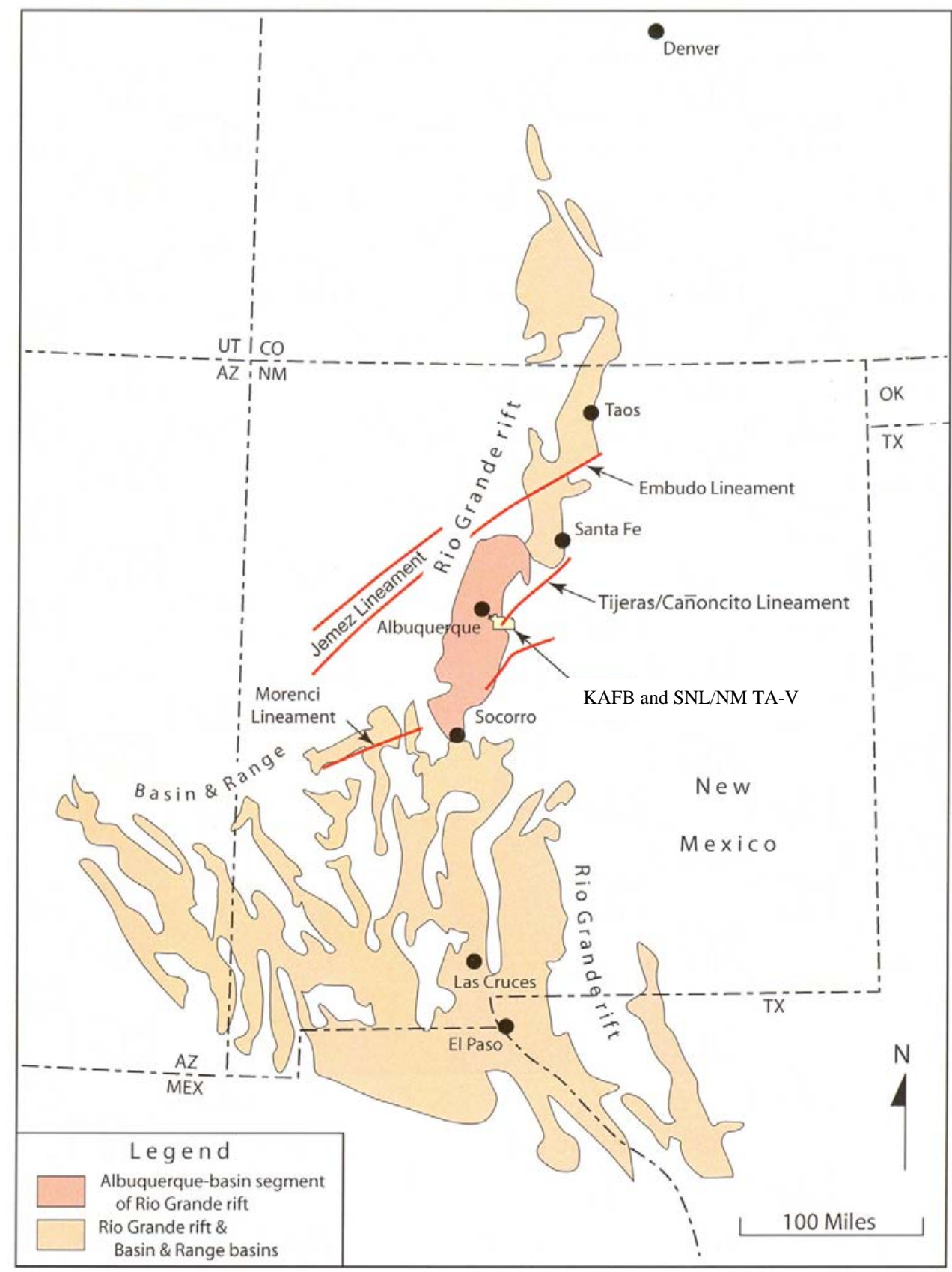

From Van Hart, 2003; modified from Kalstrom et al. 1999 and Pazzaglia et al. 1999

DVH. Nov. 2002

Figure 2-1. Location of the Rio Grande Rift, Albuquerque Basin, Select Precambrian Lineaments (in red), Kirtland Air Force Base (KAFB), and SNL/NM TA-V. 
The uplifted mountains to the east of the Albuquerque Basin act as groundwater flow boundaries and provide a source of streamflow and alluvial sediments into the basin from mountain drainages. Streamflow originating from these drainages furnishes a source of surface-water recharge to alluvial-fan sedimentary deposits along the basin margins. Chemical interactions between water and rocks in these drainages affect the chemistry of water recharged to the Santa Fe Group aquifer.

\subsubsection{Hydrostratigraphic Framework}

The Albuquerque Basin is filled with sedimentary deposits of the Santa Fe Group. Basin-fill deposits of the Santa Fe Group within the Albuquerque Basin are composed of distinct lithofacies, defined by depositional mode and characterized largely by texture. The ARG lithofacies consists of well-sorted, coarse-grained, fluvial sands and gravels that were transported from distant sources to the north during the development of the through-flowing drainage of the Rio Grande. ARG sediments typically are highly permeable. The alluvial-fan lithofacies consists of poorly sorted, lenticular sand, silt, and clay from more locally derived drainages eroding uplifted rocks along the eastern edge of the Rio Grande Rift. These sediments typically are much less permeable.

\subsubsection{Regional Recharge}

Recharge to the Santa Fe Group aquifer occurs from infiltration of streamflow from the Rio Grande and arroyos, from infiltration of areal precipitation, and from underflow originating from mountain-front recharge. On the federal property that includes SNL/NM, Tijeras Arroyo and Arroyo del Coyote provide limited recharge, as does mountain-front recharge, when it connects across the fault complexes. Areal precipitation is estimated to provide a negligible contribution, as 95 to $99 \%$ or more is estimated to be lost to evapotranspiration (SNL/NM 1998).

\subsubsection{Regional Discharge}

Regional discharge occurs as groundwater moves out of the Albuquerque Basin into downgradient basins on the Rio Grande Rift as underflow or through discharge to the Rio Grande (Figure 2-2). Discharge also occurs as pumpage from the COA municipal production well fields. The discharge is greater than recharge and effectively dewaters the aquifer on the federal property. Seasonal fluctuations are apparent only in wells at the north end of the federal property (SNL/NM 1998). The seasonal effect is damped out and becomes insignificant between the pumping centers and TA-V.

\subsubsection{Regional Groundwater Flow}

Prior to development of water resources in the Albuquerque area, groundwater in the Albuquerque Basin flowed generally from the north to the south, with a westward component of flow from recharge areas along mountain-front boundaries to the east (Bartolino and Cole 2002). As the Santa Fe Group aquifer has been developed as a source for municipal and industrial water supplies, groundwater flow directions have been partially altered toward pumping centers

(Figure 2-2). 

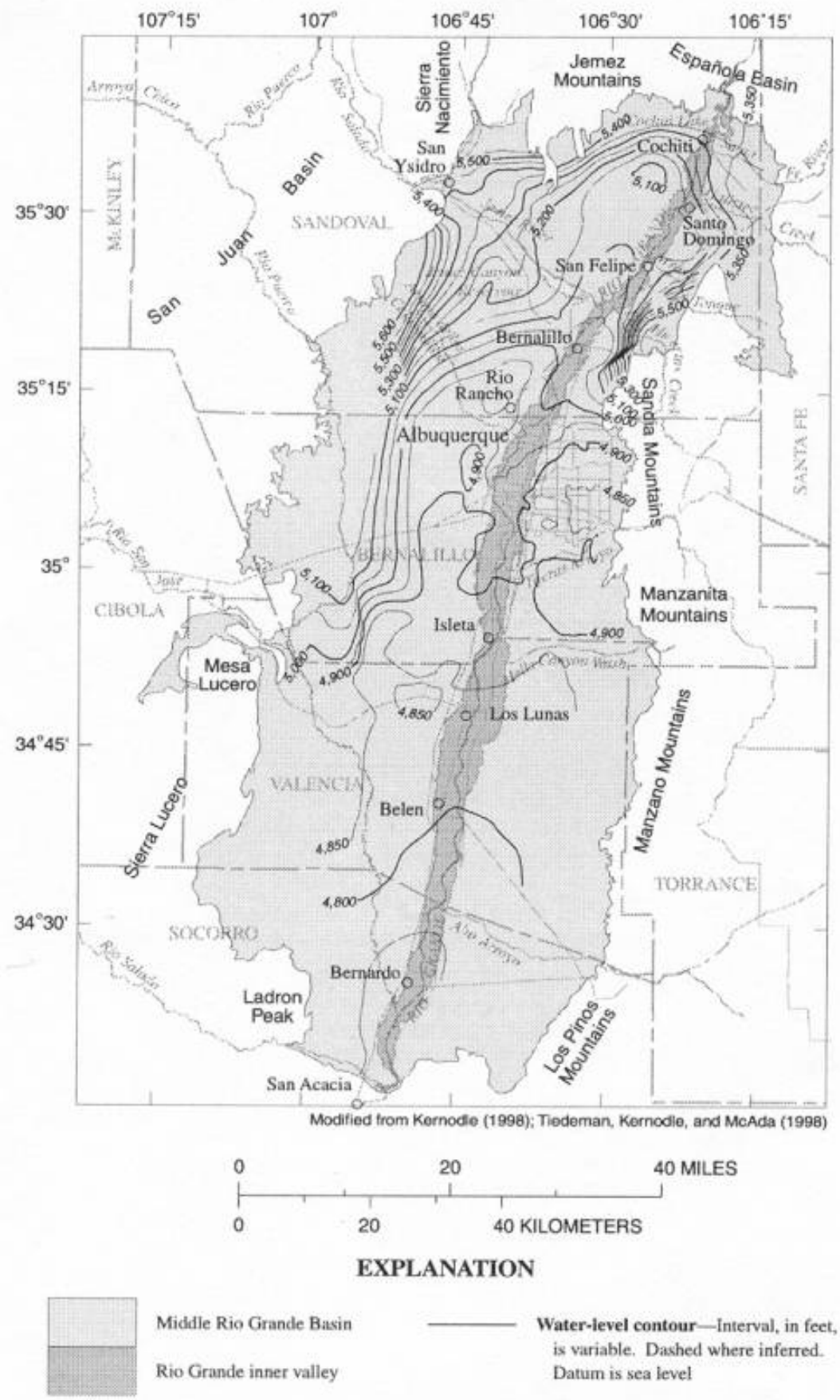

From Bartolino and Cole 2002

Figure 2-2. Configuration of the regional groundwater surface in the Albuquerque Basin, 1994-1995. 
On SNL/NM and KAFB property, the predominant groundwater flow was westward prior to water resources development (Bexfield and Anderholm 2000). Recent potentiometric surface maps and numerical modeling studies show the overpowering hydrologic influence of the pumping centers just north of the federal boundaries. The Ridgecrest supply wells, in particular, are completed less than 1 mile north of the federal boundary and are screened in the north-south trending fluvial deposits. Their capture zones extend south via these deposits onto federal property (SNL/NM 2001; Plate 3-2). The U.S. Air Force owns and operates a lesser influential network of supply wells within the federal boundaries. Together these pumping centers contributed to today's post-development north-northwest groundwater flow direction west of TA-V.

\subsection{Hydrologic Conditions at TA-V}

Contaminant transport from TA-V sources is controlled by local hydrologic conditions. Subsequent sections summarize local hydrostratigraphic units, groundwater flow, and contaminant transport at TA-V.

\subsubsection{Hydrostratigraphic Units}

The vadose zone at TA-V is approximately $500 \mathrm{ft}$ thick and consists of heterogeneous, lenticular, coarse- to fine-grained deposits (Figure 2-3). The underlying aquifer at TA-V consists of fine-grained, clay-rich sediments of the alluvial-fan lithofacies of the Santa Fe Group. These sediments interfinger to the west of TA-V with the highly permeable sediments of the ARG.

The horizontal hydraulic conductivity of the alluvial-fan lithofacies at TA-V reasonably ranges from 0.1 to $35 \mathrm{ft} /$ day, based on aquifer tests conducted in TA-V wells (Orr and Dettmers 2004). The horizontal hydraulic conductivity of the ARG is as large as $150 \mathrm{ft} /$ day. The vertical hydraulic conductivity of both lithofacies is considered to be much smaller because of the layered character of the sediments. The effective porosity, a measure of the interconnected pore spaces in the alluvial-fan lithofacies, is approximated from measurements of total porosity and moisture content to be $25 \%$.

\subsubsection{Groundwater Flow at TA-V}

Groundwater in the vicinity of TA-V is derived principally from mountain-front recharge to the east. Groundwater flows generally from east to west (Figure 2-4) through the low-permeability alluvial-fan lithofacies, as shown on the subregional 2000 potentiometric surface (SNL/NM 2000). The measured hydraulic gradient through these deposits is approximately 0.005 , based on water-level differences between the Area V North (AVN) wells and well NWTA-3.

Potentiometric contours indicate that groundwater flow paths intercept the high-permeability ARG lithofacies approximately $10,000 \mathrm{ft}$ to the west of TA-V and turn to the north in response to pumpage from large municipal well fields north of KAFB.

Based on a reasonable range of hydraulic properties, the velocity of groundwater flow at TA-V was estimated to range from 0.5 to $168 \mathrm{ft} / \mathrm{yr}$ (Orr and Dettmers 2004). The approximate location of the center of trichloroethene (TCE) mass presently is near well LWDS-MW1, approximately $300 \mathrm{ft}$ downgradient from the drainfield. Based on the location of this center of contaminant mass, movement of the mass of contaminant from the drainfield has occurred at a rate of at least $8 \mathrm{ft} / \mathrm{yr}$. 
$\square$
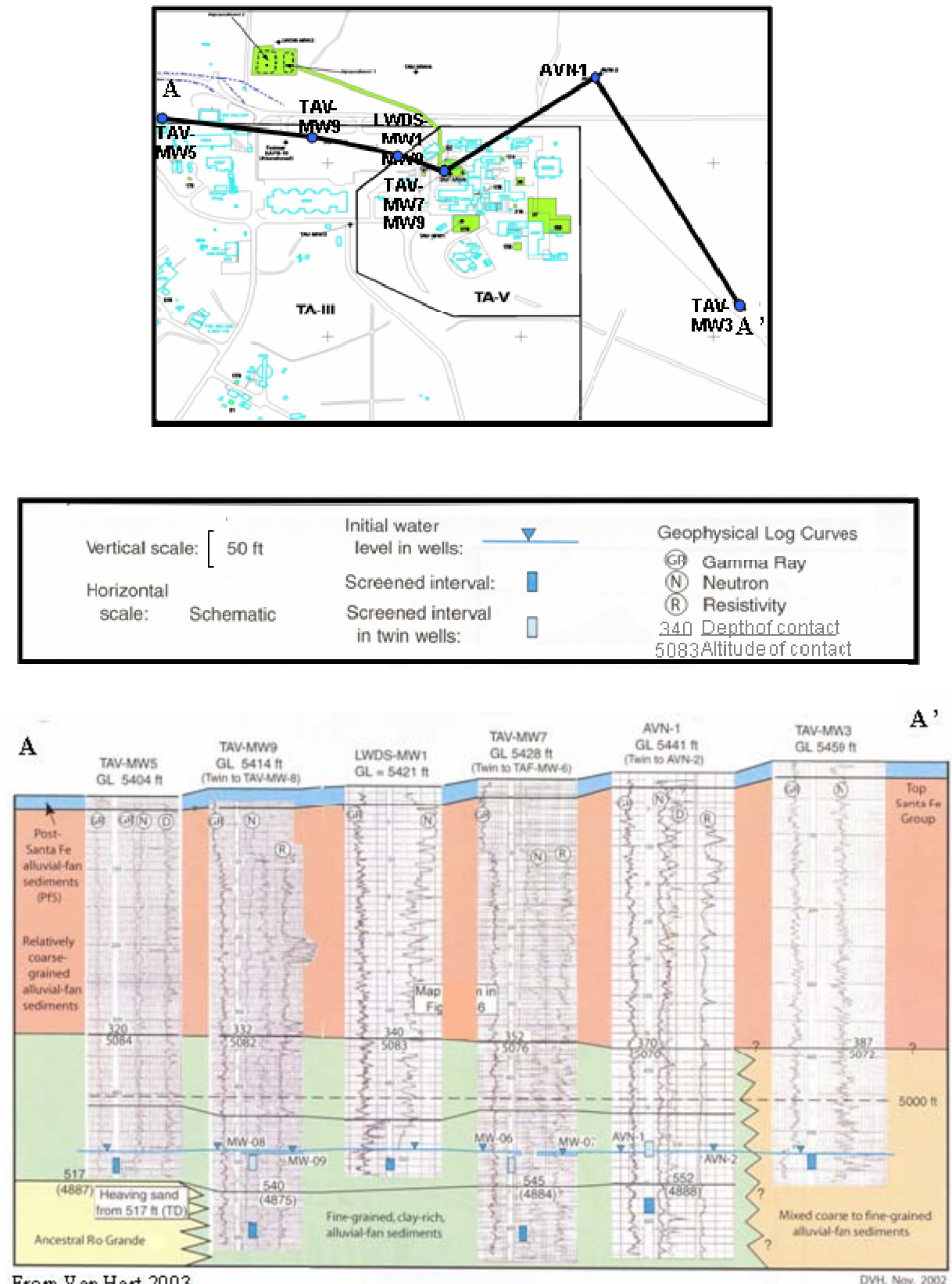

From V an Hart 2003

WH, Nov. 2002

Figure 2-3. Geophysical-log correlation Section A-A', extending from west to east across SNT /NM TA-V.

C-16 


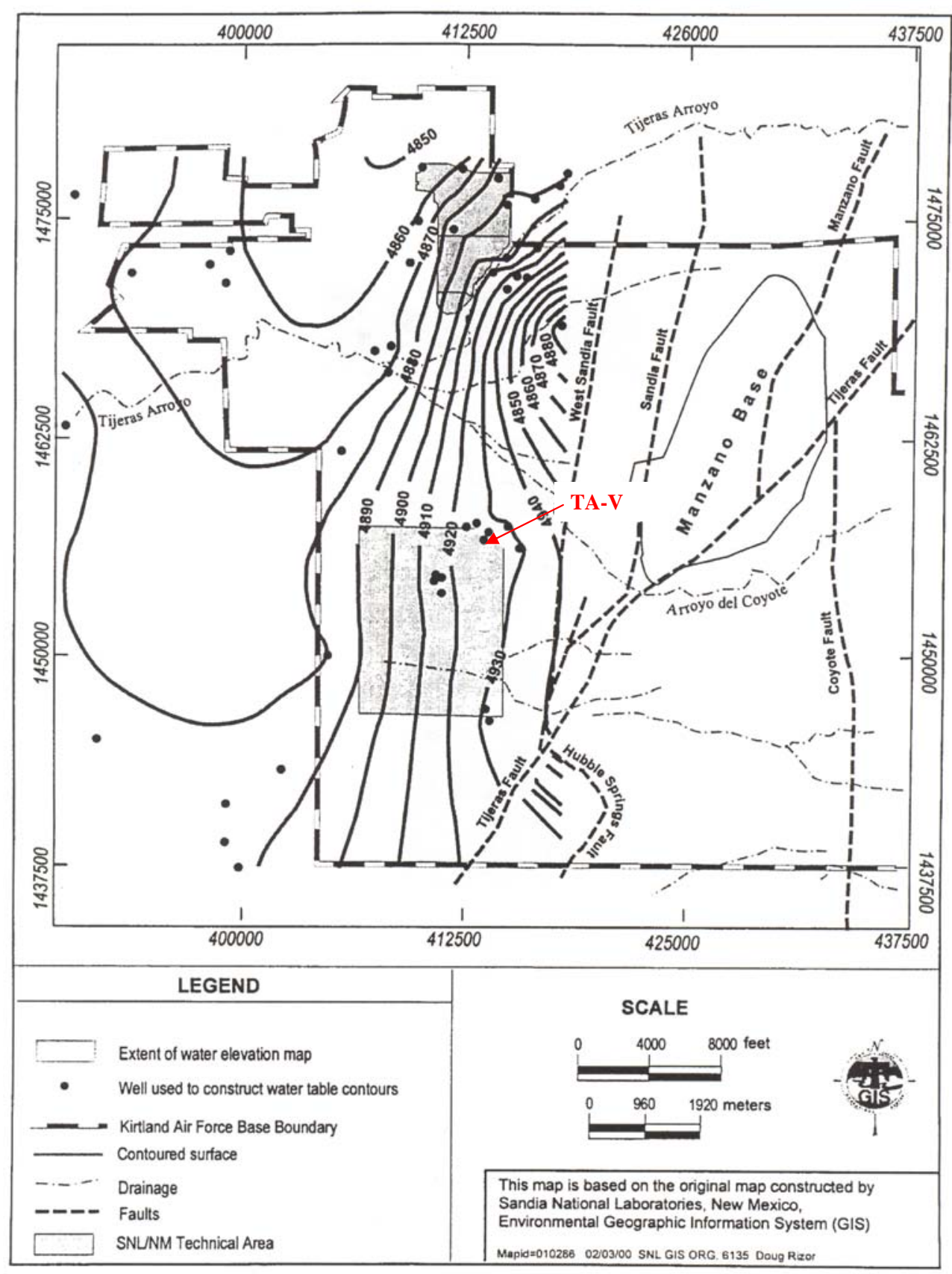

From SNL/NM 2000

Figure 2-4. Subregional potentiometric surface in the vicinity of TA-V, 2000. 
A more-refined estimate of groundwater flow velocity was derived subsequent to the Current Conceptual Model from contaminant first-arrival data. The apparent first arrival of TCE in water from well LWDS-MW8 occurred in 2001. This well is approximately $750 \mathrm{ft}$ downgradient from the Liquid Waste Disposal System (LWDS) drainfield. If vertical flow in the vadose zone was relatively rapid during periods of wastewater disposal at TA-V, and water contaminated with TCE first entered the aquifer during 1963-1967, the travel time through $750 \mathrm{ft}$ of the alluvial-fan lithofacies to LWDS-MW8 was estimated to be from 35 to 39 years. An average velocity of approximately $20 \mathrm{ft} / \mathrm{yr}$ was derived from these travel time estimates.

Based on this estimate of velocity, the Darcy Flow Equation was used to estimate an average hydraulic conductivity for the alluvial-fan lithofacies. Discharge through a unit cross-sectional area of the aquifer was estimated (from the estimated average velocity of $20 \mathrm{ft} / \mathrm{yr}$ and an effective porosity of 0.25 ) to be $5 \mathrm{ft}^{3} / \mathrm{yr}$ or approximately $0.01 \mathrm{ft}^{3} /$ day. The average hydraulic conductivity of the alluvial-fan lithofacies was estimated from this unit-area discharge and the measured gradient of 0.005 to be approximately $2 \mathrm{ft} /$ day, within the range of hydraulic conductivity determined from aquifer tests.

\subsubsection{Contaminant Transport in Groundwater at TA-V}

Contaminants of concern (COCs) in groundwater at TA-V include TCE, tetrachloroethene (PCE), and nitrate. These contaminants have been identified as COCs because they have been detected above maximum contaminant levels (MCLs) in water samples from monitoring wells. The section describes the contaminant source term and contaminant transport and distribution in the vadose zone and aquifer.

Contaminant Source Term - COCs in groundwater at TA-V have been identified based on detections above MCLs in samples collected from monitoring wells. These COCs consist of PCE, TCE, and nitrate.

Wastewater disposal facilities at the TA-V (Figure 2-5) are believed to be the primary sources for low levels of TCE contamination in the groundwater in this area. These facilities include drainfields and surface impoundments of the LWDS and TA-V seepage pits. The LWDS consists of a set of three holding tanks and associated pumping system (Solid Waste Management Unit [SWMU] 52), a drainfield (SWMU 5), and two surface impoundments (SWMU 4). The LWDS was used for the disposal of reactor cooling process water from the Sandia Engineering Reactor Facility and liquid wastes from other reactor support facilities in TA-V. The LWDS drainfield was operated from 1963 until it reportedly collapsed in 1967, receiving a total volume of 6,486,000 gal of wastewater (SNL/NM 1999).

Wastewater disposal history at TA-V includes disposal in the TA-V seepage pits (SWMU 275) from the early 1960s until 1992 (30 to 50 million gal of water), LWDS drainfield disposal from 1963-1967 (6.5 million gal of water), and disposal to the unlined LWDS impoundments from 1967-1972 (12 million gal of water). After 1992, treated wastewater was disposed to the COA sewage system. Other potential sources of local recharge may have included leakage from wastewater transfer piping. 


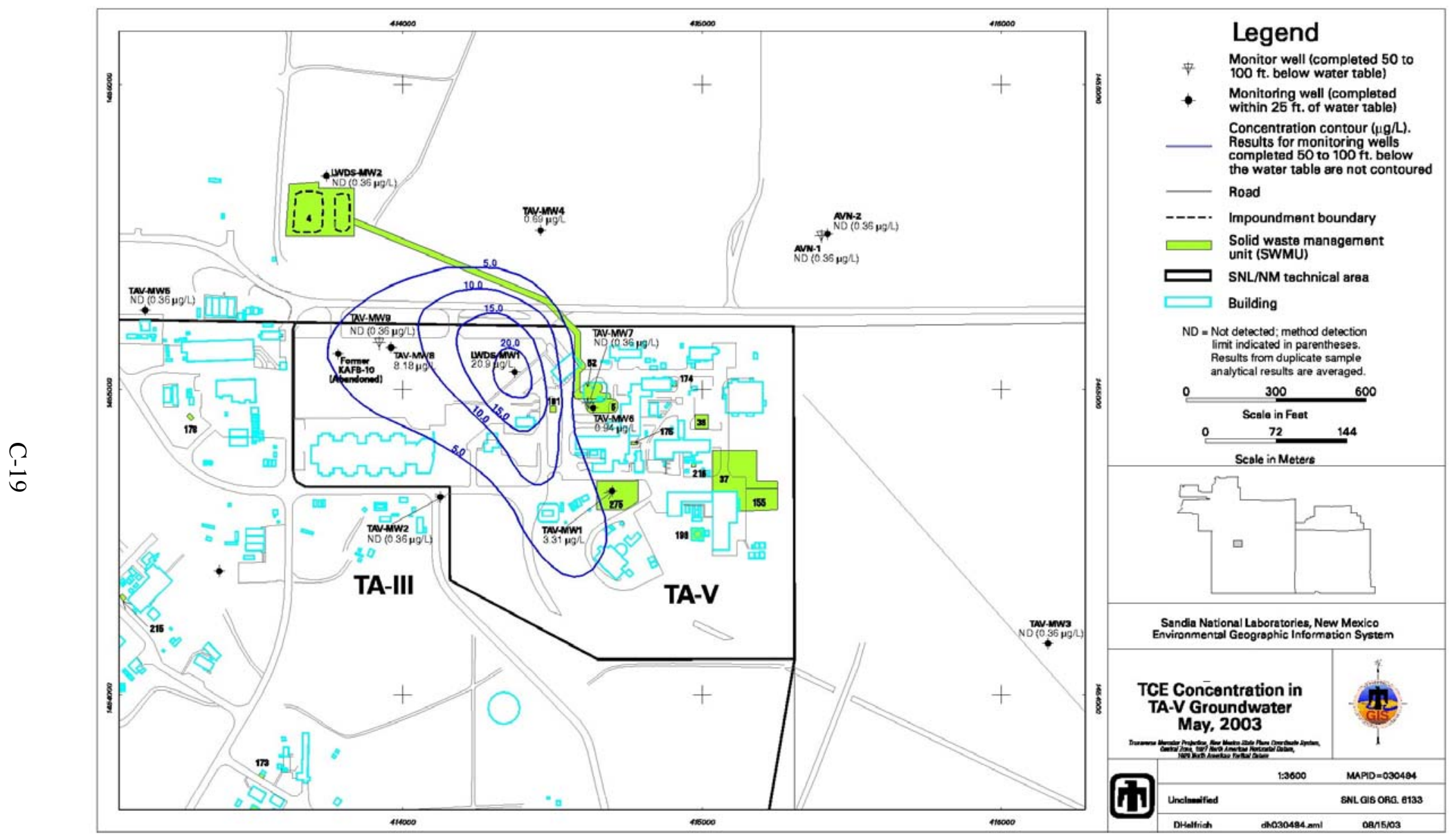

Figure 2-5. Location of wastewater disposal facilities and the TCE plume within the TA-V area. 
Industrial solvents, including TCE, used in conjunction with operations and activities at TA-V machine shops and chemistry laboratories were contained in wastewater disposed to the TA-V seepage pits and to the LWDS drainfield and impoundments. The amounts of these solvents are not documented. Solvent disposal was eliminated in the early 1980s as guidance was provided concerning appropriate use and disposal of solvents. Based on distribution of TCE in groundwater, the most plausible sources of disposal are the LWDS drainfield and the TA-V seepage pits.

The seepage pits also received sanitary wastes disposed to TA-V septic systems. These sanitary wastes contained nitrate, which served as a local source of nitrate contamination in groundwater.

Nitrate occurs primarily in the aqueous phase in both the vadose zone and the aquifer. It is nonsorptive and for the most part does not exchange on sediment surfaces in the vadose zone or groundwater. Therefore, any locally derived nitrate was most likely transported through the vadose zone with the initially disposed wastewater and does not represent a residual source term in the vadose zone.

Contaminant Transport through the Vadose Zone - Soil-vapor and soil samples collected from the land surface to the water table during recent drilling operations have indicated only minor evidence of solvent concentrations in the vadose zone beneath the drainfield. Soil samples collected during these operations have contained no excessive moisture. Based on these data, movement of water and contaminants through the $500-\mathrm{ft}$ thick vadose zone was likely rapid and vadose-zone drainage occurred soon after cessation of wastewater disposal. This information supports the concept of rapid vertical flow and minimal spreading beneath TA-V contaminant source sites.

The drainfield consisted of a 3-ft diameter tile drain buried in a 36- $\mathrm{ft}$ deep trench. Assuming that the length of the drain was $50 \mathrm{ft}$, the wetted area below the drain would have been approximately $150 \mathrm{ft}^{2}$. With the $500-\mathrm{ft}$ thick vadose zone (and assuming no lateral spreading), the minimum volume of sediments encompassed by the area directly beneath the drain would have been $75,000 \mathrm{ft}^{3}$. Assuming a range of porosity of $15 \%$ (based on moisture content in vadose-zone sediments) to $25 \%$ (accepted values for the aquifer), the pore volume in a vertical column between the drain field and the water table would have been 11,250 to $18,750 \mathrm{ft}^{3}$, or about 84,150 to 104,250 gal. Approximately 6.5 million gal, or 46 to 77 pore volumes, was disposed to this drainfield during 1963-1967. Even with significant spreading, much of this wastewater probably would have moved rapidly through the vadose zone along saturated preferential flowpaths and would have reached the water table during the 5-year period of disposal.

In contrast to the drainfield, the TA-V seepage pits were used for wastewater disposal for more than 30 years and were discontinued in 1993. The long-term disposal probably resulted in long-term rapid saturated flow through the vadose zone. Disposal of TCE to the seepage pits likely was discontinued in the early 1980s and water without TCE was disposed to the seepage pits from then until 1993.

Contaminant Transport in the Santa Fe Group Aquifer - TCE is present in water moving through the Santa Fe Group aquifer beneath TA-V. TCE plume dimensions at concentrations exceeding $5 \mu \mathrm{g} / \mathrm{L}$ were approximately $600 \times 1,200 \mathrm{ft}$ during May 2003 (Figure 2-5). The May 2003 concentration in water from well LWDS-MW1 was $20.9 \mu \mathrm{g} / \mathrm{L}$ (as high as $26 \mu \mathrm{g} / \mathrm{L}$ in November 2000). Based on residual TCE concentrations and moisture content in the vadose 
zone, present concentrations of TCE in groundwater were derived from previous aqueous disposals and do not represent a secondary release from residual contaminant source terms.

TCE concentration isopleths for 2003, as shown in the TA-V CME Work Plan (Hall, Dettmers, and Lebow 2004), indicate that the center of TCE mass has migrated at least $300 \mathrm{ft}$ west and northwest from the LWDS drainfield since disposals ceased. Based on this migration, TCE travel time in the aquifer is estimated to be at least $8 \mathrm{ft} / \mathrm{yr}$. This travel-time estimate does not account for attenuation of the contaminant mass in groundwater.

Subsequent to the Current Conceptual Model, evaluation of the first TCE arrival in well LWDS-MW8 resulted in an estimated groundwater velocity of approximately $20 \mathrm{ft} / \mathrm{yr}$. At the estimated groundwater velocity of $20 \mathrm{ft} / \mathrm{yr}$, the first TCE arrival in the vicinity of LWDS-MW1 would have occurred during 1978-1982; about 15 years after the contaminant reached the aquifer. Based on analytical data, the apparent first arrival of TCE in water from well LWDS-MW1 occurred prior to 1994 (Figure 2-6) but no earlier information is available.

A dilute lobe of the TCE plume occurs south of well LWDS-MW1 and west of the TA-V seepage pits (Figure 2-5). This lobe is attributed to TCE originating from the seepage pits and subsequently diluted by continued discharges to the pits after TCE disposal ceased. Distribution of TCE from this source is attributed to dilution and attenuation. TCE concentrations in water from TAV-MW1, located within the seepage pit area, were first detected in 1994. These detections indicate that a decade of continued disposal of "clean" water may have diluted TCE concentrations in groundwater adjacent to well TAV-MW1 to below detection. Upon cessation of disposal, residual concentrations may have been detected because this dilution was stopped and upgradient water containing low TCE concentrations began to move downgradient toward the well.

In this case, TCE concentrations in disposed wastewater may have been relatively diluted by the large volumes of water disposed to the seepage pits for a long period of time. The combination of TCE dilution in large volumes of disposed wastewater and the subsequent flushing with wastewater not containing TCE after the early 1980s may have resulted in lower TCE concentrations in water from monitoring wells downgradient from the TA-V seepage pits. Furthermore, the TCE concentration in water from downgradient well TAV-MW2 is below the detection limit. Concentrations in water from well TAV-MW1 have ranged from zero to approximately $4 \mu \mathrm{g} / \mathrm{L}$ since 1994.

PCE was detected at concentrations exceeding the MCL of $5 \mu \mathrm{g} / \mathrm{L}$ in water samples from one well completed approximately $100 \mathrm{ft}$ below the water table during several sampling events. PCE was not detected in nearby water-table wells.

Nitrate has been detected above the MCL of $10 \mathrm{mg} / \mathrm{L}$ (as nitrogen) in water from several TA-V wells. Sampling events through May 2003 showed nitrate concentrations ranging from less than 5 to more than $10 \mathrm{mg} / \mathrm{L}$ (as nitrogen). Nitrate in water within the extent of the TA-V TCE plume is attributed to local septic system disposals. Nitrate in water from wells east of TA-V exceeded $10 \mathrm{mg} / \mathrm{L}$ (as nitrogen) during the summer and fall of 2001. These nitrate concentrations are derived from upgradient sources and are not within the scope of the TA-V CME. 

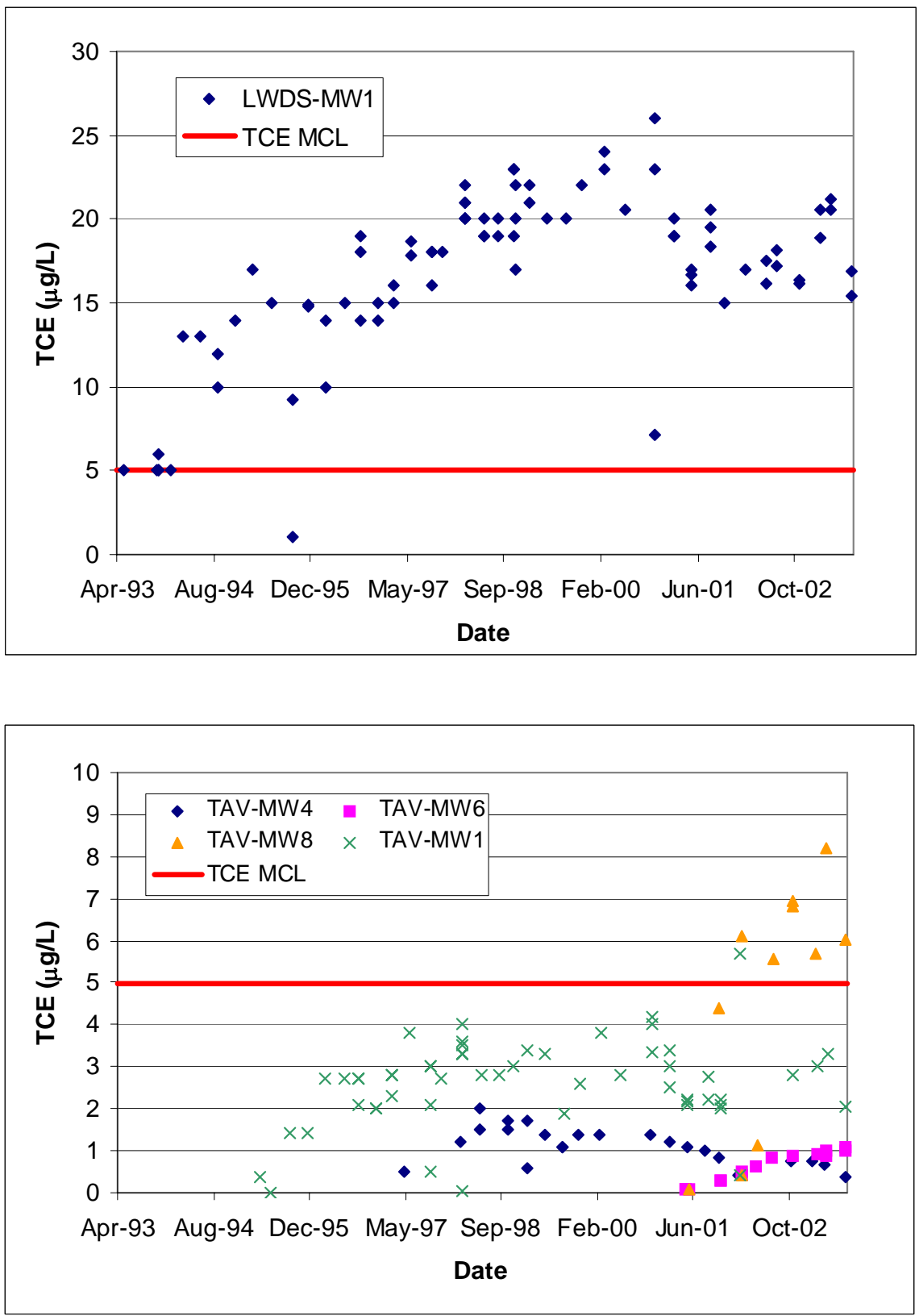

Figure 2-6. TCE concentrations over time at selected TA-V wells.

\section{C-22}


Potential downgradient receptors for the TA-V groundwater plume are the COA and KAFB well fields to the north. Pumpage from the COA well fields will prevent TCE and other contaminants from migrating southward toward Isleta Pueblo or westward toward the proposed Mesa del Sol well field.

Additionally, downgradient TCE concentrations are decreasing in groundwater to below detection limits through dispersion and dilution as the plume moves toward the more hydraulically conductive ARG deposits west of TA-V. Capture-zone analyses for downgradient receptors in the $\mathrm{COA}$ and $\mathrm{KAFB}$ well fields indicate that contaminant travel times exceed 100 years from TA-V (SNL/NM 2001).

\subsubsection{Summary of the Conceptual Model of Groundwater Flow and Contaminant Transport at TA-V}

Key elements of the conceptual model of groundwater flow and contaminant transport at TA-V consist of the following:

- Wastewater containing dissolved organic and inorganic constituents (TCE, PCE, and nitrate) was disposed to the subsurface in the TA-V seepage pits (1960s-1992), LWDS drainfield (1963-1967), and to the LWDS surface impoundments (1967-1971).

- Wastewater moved rapidly through the 500-ft vadose zone, transporting contaminants to the aquifer. Vadose-zone drainage was rapid after disposals stopped. Subsequent residual moisture and contaminant concentrations were minimal. Continued flushing of contaminant-free water at the seepage pits further diluted contaminant concentrations in groundwater downgradient of the seepage pits.

- A secondary source of release is not present in the vadose zone or the saturated zone at TA-V.

- Dissolved contaminants have moved slowly to the west with local groundwater flow. Presently, measurable concentrations of contaminants have been observed in water from monitoring wells about $700 \mathrm{ft}$ downgradient from sources. The rate of groundwater flow at TA-V is estimated from first arrival data to be about $20 \mathrm{ft} / \mathrm{yr}$. The large ratio of horizontal to vertical hydraulic conductivity has prevented deep circulation of contaminants.

- Groundwater moves westward approximately 10,000 ft through the alluvial-fan lithofacies, where it enters the highly permeable ARG lithofacies moving north toward downgradient receptors within municipal pumping centers. 


\subsection{NUMERICAL SIMULATION OF CONTAMINANT FATE AND TRANSPORT}

A USGS regional numerical model of groundwater flow was initially adapted to evaluate contaminant dilution in groundwater downgradient from TA-V (Written Commun., Greg Ruskauf, INTERA Inc., November 10, 2004). The objective of this modeling analysis was to determine the reduction in dissolved concentration of contaminants (i.e., TCE) derived from TA-V sources as those contaminants migrate with groundwater that is drawn toward the capture zone of COA water supply systems. Analysis of these regional numerical model results showed that the regional model was too large for the scale of the TA-V contaminant dilution problem. A simplified cross-sectional analysis was developed to refine estimates of downgradient dilution of a conservative contaminant. Subsequent sections describe the regional model and the simplified cross-sectional analysis.

\subsection{Regional Numerical Model}

The USGS conducted a study to evaluate the consequences of potential water-management strategies on components of the hydrologic system in the Albuquerque Basin. This study included development of a regional numerical model (McAda and Barroll 2002) that was used to evaluate different water-management scenarios through 2040 (Bexfield and McAda 2003).

This model was adapted for use in evaluating the effects of groundwater remediation activities at SNL/NM. Stage-2 investigations at TA-V utilized this model to evaluate potential dilution of contaminants in groundwater moving toward downgradient receptors. Subsequent sections describe the regional model structure, dilution study strategy, adaptations for the dilution study, numerical modeling results, and implications on the downgradient distribution of contaminants.

\subsubsection{Regional USGS Groundwater Model Structure}

The USGS regional model (McAda and Barroll 2002) simulates groundwater flow through the Santa Fe Group aquifer system contained in the Albuquerque Basin. The model, which simulated groundwater flow in the Albuquerque Basin through the year 2000, is the most recent version of the USGS model of groundwater flow in the Albuquerque Basin. This model includes refinements to a previous numerical model, including improvements to the geologic framework, recharge, and anisotropy, and better simulation of inner-valley groundwater/surface water relations. This flow model is intended to integrate components of the groundwater flow system and to provide a water management tool. The Bexfield and McAda (2003) model slightly revised this model to simulate hydrologic conditions through 2040.

\subsubsection{Model Grid}

The aquifer system is represented by nine model layers that extend to basement rocks that are as much as 9,000 ft below sea level. The model consists of a north-south horizontal cell grid of 156 rows and 80 columns (Figure 3-1). Individual cells are $1 \mathrm{~km}$ on a side. 


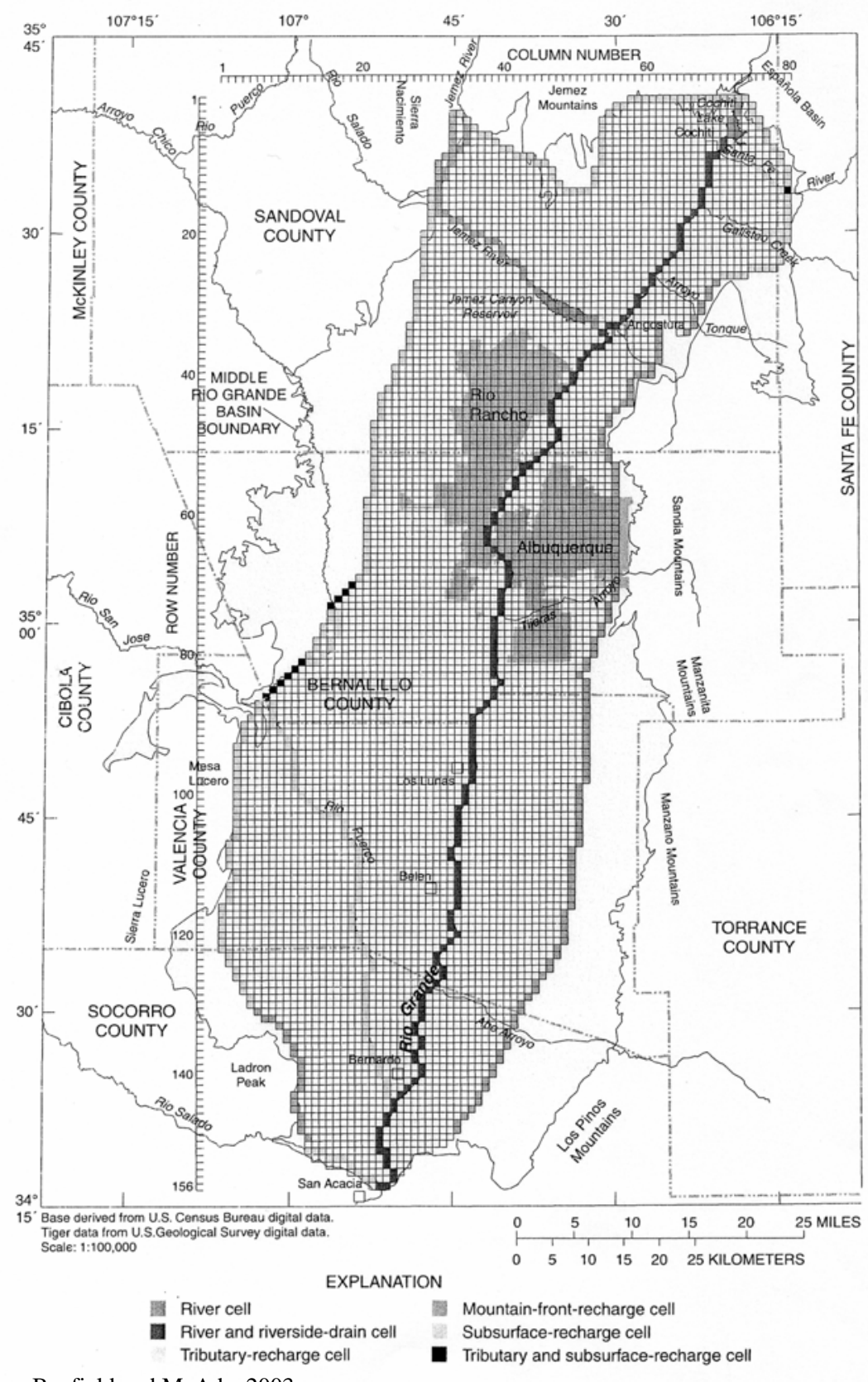

From Bexfield and McAda, 2003

Figure 3-1. USGS regional model grid and recharge cells, Albuquerque Basin. 


\subsubsection{Model Distribution of Hydraulic Properties}

Hydrologic properties assigned to the model to represent the Santa Fe Group aquifer system include horizontal and vertical hydraulic conductivity, specific storage, and specific yield. Hydrologic properties are vertically and horizontally anisotropic. The preferred orientation of horizontal hydraulic conductivity is along the north-south axis, with horizontal anisotropy ranging from 1:1 to 1:5. Vertical to horizontal anisotropy is represented areally as a ratio of 1:150.

\subsubsection{Model Boundary Conditions}

The USGS regional model represents mountain-front, tributary, and subsurface recharge; canal, crop-irrigation, and septic-field seepage; and groundwater withdrawals as specified-flux boundaries.

\subsubsection{Dilution Study Strategy}

A modeling strategy was developed as part of Stage-2 studies to assess downgradient dilution at TA-V. This strategy incorporated the following steps:

- Revisions were made to the McAda and Barroll (2002) model to support flow and transport simulations representing dilution of contaminants derived from TA-V disposal. The model used the three pumping scenarios described by Bexfield and McAda (2003) to develop basin-wide predictive simulations through 2040.

- A particle-tracking program was used to evaluate a flow path from TA-V for each of the three scenarios. The flow paths of particles released in the vicinity of LWDS MW-1 were tracked as they were drawn into the capture zone of the pumping wells.

- Concentration changes in cells along the flow path were calculated in response to a unit concentration of a conservative contaminant injected in the cell underlying TA-V. These changes were used to determine a concentration reduction factor along the flow path.

\subsubsection{Model Adaptations to SNL/NM}

Hydraulic properties assigned in the USGS regional model to cells representing the SNL/NM were not in agreement with characterization data from SNL/NM wells. Specifically, the largest hydraulic conductivity used in the USGS model in the vicinity of SNL/NM was $21 \mathrm{ft} /$ day, with a horizontal anisotropy of 1:2. Hydraulic conductivity of ARG deposits at SNL/NM, derived from aquifer tests, was as much as $150 \mathrm{ft} /$ day.

The USGS model was adapted for the dilution study to better match measured hydraulic conductivity values. Hydraulic conductivity assigned to cells representing the north-trending trough of ARG sediments was adjusted to a north-south oriented hydraulic conductivity of $150 \mathrm{ft} /$ day.

Predictive pumpage scenarios were added to the model to reflect three scenarios used by Bexfield and McAda (2003) to evaluate the effect of future groundwater withdrawals on the Albuquerque Basin through 2040, as follows: 
- Scenario 1 - Continuous Pumping. Represented conditions of medium groundwater withdrawals. In this scenario, groundwater pumping through 2040 was held constant to pumping withdrawal rates from the year 2000 and averaged approximately 113,000 acre-ft/yr.

- Scenario 2 - Increased Pumping. Represented conditions of large groundwater withdrawals. In this scenario, water-demand projections provided by the COA were met by increased pumping. Withdrawals increased steadily from about 113,000 to 170,000 acre-ft/yr during 2001-2040.

- Scenario 3 - Reduced Pumping. Represented conditions of small groundwater withdrawals. In this scenario, water-demand projections were offset by annual streamflow contributions of approximately 100,000 acre-ft.

\subsubsection{Model Results}

The results using the three scenarios indicated that substantial water-level declines would occur in some areas of the basin. However, the reduced pumping scenario (Scenario 3) would result in a rising water table over broad areas of the city.

Particle track analyses were conducted using the three scenarios. In the reduced pumping scenario (Scenario 3), a particle introduced into the model at the water table in a cell representing ARG deposits west of TA-V moved about $2 \mathrm{~km}$ north in 25 years. In the continuous pumping (Scenario 1) and increased pumping (Scenario 2) scenarios, particles introduced in the same location did not move as far. This difference is attributed to a model layer drying up in the vicinity of pumping wells, because of sustained or increased withdrawals and subsequent reduction in groundwater flow in that layer.

A previous model had been used to evaluate capture zones for COA and KAFB production wells (SNL/NM 2001). This model study indicated that travel times from areas close to TA-V north to production wells may exceed 100 years. The study also reproduced the measured head distribution, as shown on the potentiometric surface map (Figure 2-4), with flow predominantly to the west within the alluvial-fan deposits joining the high conductivity ARG deposits west of TA-V.

The particle track analysis conducted using the present regional model did not reflect this predominantly westward flow. Particles introduced at the water table at TA-V migrated northwest and north within one cell over the 25-year simulation. It became apparent that the large cell size precluded local representation of the transition from the alluvial-fan lithofacies to the ARG west of TA-V.

A unit contaminant concentration was introduced into the cell representing TA-V. After 30 years, the model showed the contaminant spreading northward with concentrations diluted by approximately two orders of magnitude at the Ridgecrest well field. The model results indicated that the cell size precluded adequate assessment of contaminant dilution at the scale of the TA-V contaminant plume. 


\subsubsection{Implications}

The regional groundwater model (McAda and Barroll 2002) adequately permits assessment of large-scale stresses on the aquifer system. The model provides evaluation of SNL/NM water resources within the context of the Albuquerque Basin. However, the model scale and individual cell size are too large for the scale of this TA-V dilution evaluation. Modeling runs could not be utilized to clearly define downgradient dilution of the small concentrations of solute observed at $\mathrm{TA}-\mathrm{V}$. The cell size ( $1 \mathrm{~km}$ on a side) was too large to incorporate small-scale heterogeneities that control groundwater flow and contaminant transport. Indeed, the entire TCE plume at TA-V covers less than $6 \%$ of a single model cell. Therefore, it was apparent that further analysis was required to adequately evaluate the dilution factor along a flowpath from $\mathrm{TA}-\mathrm{V}$ to the Ridgecrest well field.

\subsection{Simplified Cross-Sectional Analysis}

Groundwater flows west beneath TA-V within low-conductivity alluvial-fan deposits. Based on the hydraulic gradient and direction of flow, as indicated on the subregional potentiometric surface map (Figure 3-2), groundwater in the upper part of the aquifer moves into the high hydraulic conductivity ARG deposits approximately $10,000 \mathrm{ft}$ west of TA-V. This groundwater flow mixes with groundwater flowing north through the ARG toward municipal pumping centers.

A simple cross-sectional modeling approach was used to refine the evaluation of dilution down this flow path. This approach incorporated hydraulic properties from the adapted USGS Albuquerque Basin model. The cross-sectional modeling strategy was to use the Department of Defense Groundwater Modeling System (GMS), employing the MODFLOW groundwater model (Harbaugh and others 2000) and the MT3DMS transport model (Zheng and Wang 1999) to develop a simplified representation of cross-sectional flow along the groundwater flowpath that included TA-V. Relative concentrations of a solute were then simulated along that flowpath.

Because of symmetry problems associated with mixing of water along the flow path, the approach was divided into two cross-sectional numerical models (Figure 3-2). The first model (alluvial-fan section) represented westward groundwater flow in the alluvial fan lithofacies beneath TA-V. The second (ARG section) represented northward flow within the ARG.

\subsubsection{Cross-Sectional Groundwater Flow through the Alluvial-Fan Lithofacies beneath TA-V}

The alluvial-fan cross-sectional model represents the groundwater flow system that extends west through the low-permeability alluvial fan lithofacies from the mountain front east of TA-V to the high-permeability ARG lithofacies, as observed on the local potentiometric surface map (Figure 3-2). Water along this flowpath generally originates from mountain-front recharge to the east. Flow through the alluvial fan lithofacies is horizontally preferential because of the layered, lenticular nature of these deposits. Little, if any, recharge from rainfall occurs along the flowpath.

Grid - The simplified numerical model represented a groundwater flowpath that extends 13,600 ft west and northwest from the mountain front and Arroyo del Coyote to well PL-2, located approximately 10,000 ft northwest of TA-V (Figure 3-2). The model section consisted of two layers, with the bottom of layer 1 at an altitude of $4,870 \mathrm{ft}$ and the bottom of layer 2 at an altitude of 4,830 ft. The section consisted of a single row consisting of 68 cell columns from east to west, with cell dimensions $200 \mathrm{ft}$ long and $200 \mathrm{ft}$ wide. 


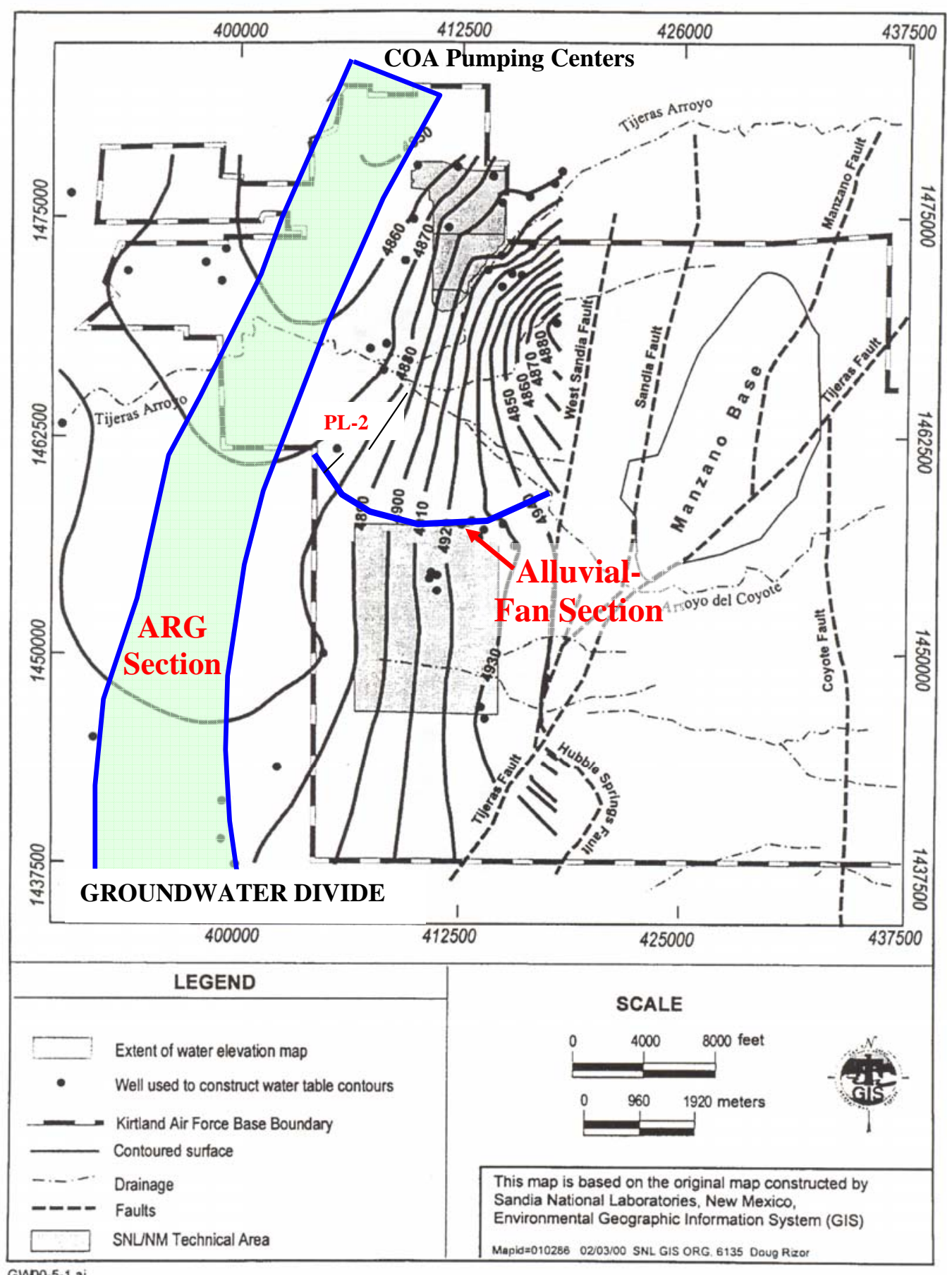

Figure 3-2. Subregional 2000 potentiometric surface for SNL and approximate location of simplified alluvial-fan and ARG groundwater cross-sections. 
Boundaries and hydrologic properties - The model represented mountain-front recharge with a constant head boundary at an altitude of 4,940 ft, derived from the regional potentiometric surface (Figure 3-2). The basinward terminus of the flowpath was represented by a constant head boundary that was defined by the altitude of a measured water level of 4,872 ft in well PL-2.

No flow was assumed to move across the longitudinal dimensions of the cross-section because the section was considered to be parallel to the flow path derived from the potentiomentric surface. No flow was assumed to occur beneath layer 2. Although this assumption is not true, it is considered to be conservative in this context because a thicker aquifer would result in increased dilution of a contaminant. The layered model permitted incorporation of the ratio of horizontal to vertical hydraulic conductivity.

The adapted USGS regional flow model used an east-west range of hydraulic conductivity from $0.1 \mathrm{ft} /$ day toward the mountain front to $150 \mathrm{ft} /$ day in areas of the ARG, with a value of $8 \mathrm{ft} / \mathrm{day}$ in cells immediately west of TA-V. This hydraulic conductivity ( $8 \mathrm{ft} /$ day) was used uniformly in the alluvial-fan cross-sectional model to represent the capability of alluvial-fan deposits comprising the aquifer beneath TA-V to transmit water. The ratio of horizontal to vertical hydraulic conductivity was 150 , the same as the ratio used in the regional model. This ratio represented the layered stratigraphic configuration that restricted vertical flow. An effective porosity of 0.25 was derived from the regional model.

An injection well was added in the model to the layer-1 cell (cell 16) representing the upper part of the aquifer beneath TA-V source areas. This well permitted addition of a solute in the dilution analysis. This injection well was assumed to contribute a flux of $30 \mathrm{ft}^{3} /$ day of water to the overall flux of water through the cell. This flux only provided a mechanism for introduction of solute and did not represent any actual flux. Although addition of this injection well affected upgradient conditions slightly, it did not modify downgradient flux.

The simplified cross-sectional flow model was run as a 200-year transient simulation. The modeled time interval was subdivided into forty 5-year stress periods.

Calibration - Simulated heads were compared to measured water levels in five wells along the section. Simulated heads in cells representing four wells downgradient from the drainfield ranged from $1 \mathrm{ft}$ higher to $2 \mathrm{ft}$ lower than measured heads. The cross-sectional flow model was calibrated sufficiently to permit a reasonable representation of flow and transport. The average gradient over the entire cross-section is precise and was constrained by the constant head boundaries at each end, which were based on the regional potentiometric surface map (Figure 3-2).

Flow model results - Simulated flow through the cross-sectional model moved from east to west. Model results showed that horizontal fluxes in layer 1 decreased downgradient as the saturated thickness in that layer decreased. This decrease was attributed to a vertical component of flow through the base into layer-2 cells. An average flux of $616 \mathrm{ft}^{3} /$ day moved out of the model at the downgradient constant-head boundary during the 200-year simulation, representing flow out of a 200 - $\mathrm{ft}$ wide strip of the upper section of alluvial-fan deposits into the ARG. This representation is considered to be reasonable, given known distribution of head and hydraulic conductivity. 
MT3DMS transport assumptions - Numerical results from the cross-sectional flow model were used to evaluate the downgradient transport and dilution of a solute in groundwater. The following assumptions were made:

- The solute was nonsorptive, moving with groundwater. This assumption was conservative with respect to TCE in an alluvial aquifer that may contain organic carbon.

- The solute did not degrade. This assumption again was conservative because biological and chemical degradation of TCE has been observed in most environments.

- The solute entered layer-1, cell 16 (Figure 3-3), at a concentration sufficient to increase the concentration in the cell to 100 units. The actual entry concentration in wastewater is not known. This starting concentration permitted ready comparison of relative downgradient concentrations.

- Solute additions continued through the injection well in layer 1, cell 16, during the initial 5-year stress period. This injection rate is equivalent to known discharges to the LWDS drainfield or to the LWDS surface impoundment. No solute was added in subsequent stress periods.

- Porosity, required for transport simulation, was assumed to be 0.25 . This was a reasonable and accepted value used in the regional model.

The cumulative effect of these assumptions was to provide a conservative estimate of downgradient contaminant concentration trends over time. This analysis is considered to be conservative because it accounts only for attenuation through longitudinal dispersion but disregards the effects of sorption, degradation, and lateral dispersion.

Transport simulation results - The simulated distribution of solute in the aquifer after eight stress periods (40 years) is shown in Figure 3-3. This period is equivalent to the period from 1963 to 2003, although it does not represent transient water-level declines from municipal withdrawals. By the fortieth year, the leading edge of the simulated contaminant plume had migrated more than 2,400 ft downgradient from the point of injection. The maximum simulated concentration was approximately $28 \%$ of the starting concentration and occurred in layer- 1 , cell 25 , approximately $1,800 \mathrm{ft}$ downgradient from the source. In contrast, the observed distribution of TCE, with concentrations ranging from 5 to $20.9 \mu \mathrm{g} / \mathrm{L}$ in 2003 (Orr and Dettmers 2004), extended approximately $900 \mathrm{ft}$ downgradient from the drainfield.

This simplified distribution overpredicted the extent of the observed horizontal distribution of TCE in 2003 in groundwater at TA-V and the contaminant transport velocity, as estimated from first arrival of TCE in downgradient monitoring wells. This overprediction may be attributed to geohydrologic and geochemical characteristics that are not represented in the model, including anomalously low hydraulic conductivity in the vicinity of TA-V and effects of degradation, sorption, and lateral dispersion on contaminant concentrations. 


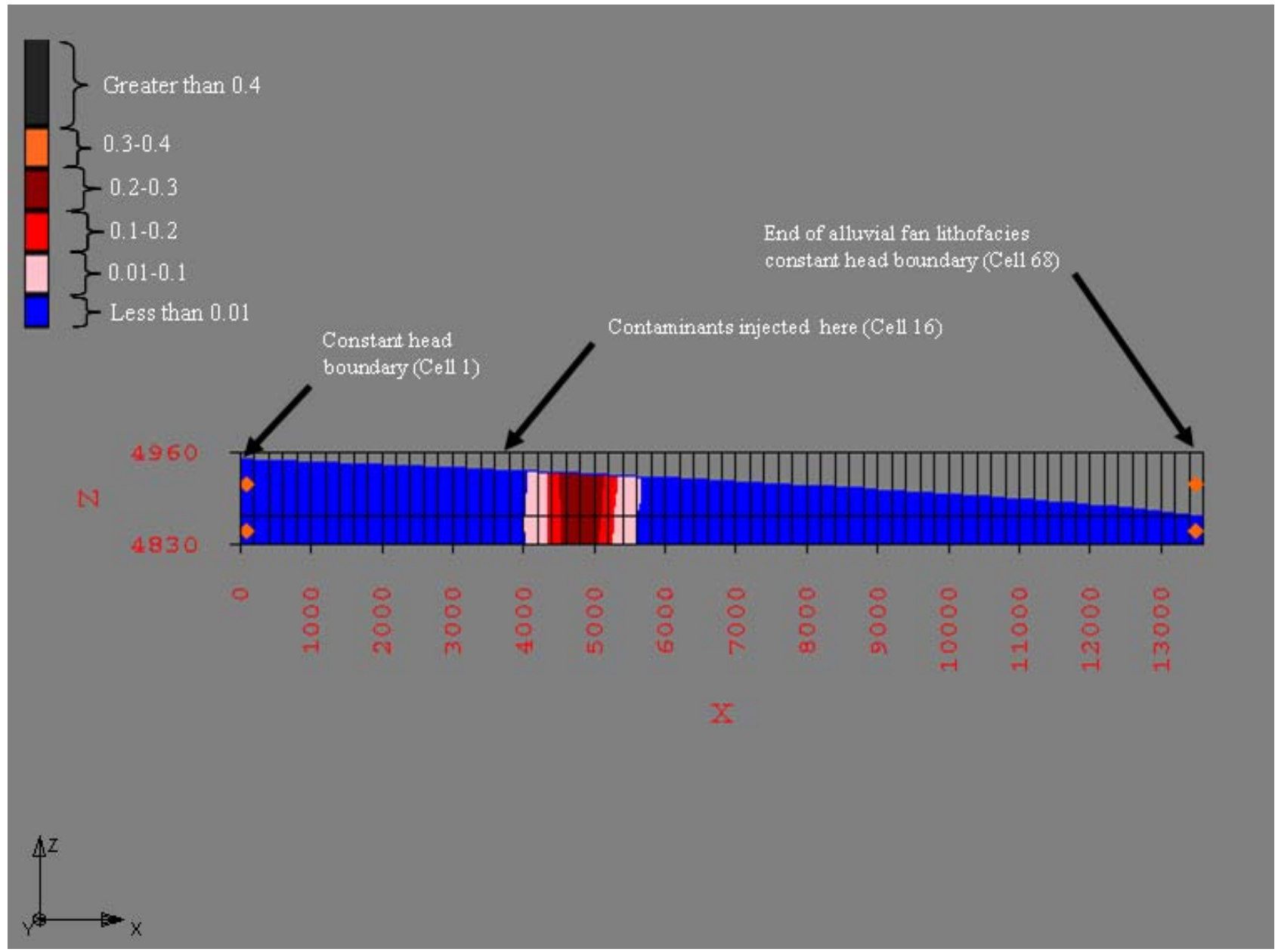

Figure 3-3. Simulated distribution of a contaminant within the simplified east-west alluvial-fan cross-sectional groundwater flow model after 40 years (10X vertical exaggeration). 
This simplified analysis resulted in a continued reduction in the contaminant concentration to approximately $20 \%$ of the original contaminant concentration (i.e., concentrations were reduced by a factor of 5) in the 2-mile long alluvial-fan flowpath downgradient from TA-V. Based on the analysis, a non-sorbing, non-degrading contaminant will reach the ARG lithofacies approximately 150 years after disposal at TA-V. Subsequent contaminant release from the alluvial-fan lithofacies into the ARG lithofacies will occur over a 45-year period because the contaminant mass has been dispersed along the flow path. The contaminant concentration peak breakthrough into the ARG will occur approximately 180 years after release at TA-V.

\subsubsection{Cross-Sectional Groundwater Flow toward Municipal Pumping Centers through the Ancestral Rio Grande Lithofacies West of TA-V}

The ARG cross-sectional model (Figure 3-2) begins south and west of KAFB near a probable groundwater divide separating flow toward pumping centers to the north from natural system flow to the south. The section represents flow northward through the high-permeability ARG lithofacies, as observed in local water-table contour maps. Water along this flowpath generally accretes from underflow out of alluvial-fan deposits to the east and recharge from the Rio Grande to the west. Flow through the ARG lithofacies is preferential horizontally because of the layered, lenticular nature of these deposits. Little, if any, recharge from rainfall occurs along the flowpath.

Grid - The simplified numerical model represented a groundwater flowpath that extends $52,800 \mathrm{ft}$ north from the probable groundwater flow divide to the Ridgecrest well field, located approximately 25,000 ft north of TA-V (Figure 3-2). The model section consisted of one layer, with the bottom at an altitude of 4,400 ft. This bottom elevation does not account for flow within underlying Santa Fe Group sediments. However, it does include most of the aquifer thickness presently utilized by pumping wells.

The section consisted of 88 cells from south to north, with cell dimensions $600 \mathrm{ft}$ long and $6,000 \mathrm{ft}$ wide. The width dimension was used to represent most of the flow through the ARG that would be derived from accreted flows from the east.

Boundaries and hydrologic properties - The model represented the probable groundwater divide to the south as a no-flow boundary. The cumulative cone of depression in the water table in the vicinity of the Ridgecrest well field has steadily developed over time because of continuous pumpage to meet municipal requirements. In the cross-sectional model, this cone of depression is represented at the northern terminus of the flowpath by a constant head at an altitude of 4,850 ft (approximate water level in well Ridgecrest 4 in 2000). Accreted flows were represented by injection wells in each cell along the section.

The adapted regional flow model had used a hydraulic conductivity of $150 \mathrm{ft} /$ day to represent the ARG. This hydraulic conductivity was used uniformly in the steady-state ARG cross-sectional model. Horizontal to vertical anisotropy was not represented in the one-layer model. An effective porosity of 0.25 was assigned to model cells based on the regional numerical model.

The simplified cross-sectional flow model was run as a 136-year transient simulation. The simulation was subdivided into 11 stress periods of variable length to permit simulation of attenuated contaminant underflow over a 45-year period from the alluvial-fan section into cell 56. 
Calibration - The model was calibrated to measured water levels by adjusting injection-well contributions representing accreted underflow in each cell. Simulated heads were compared to measured water levels in four wells along the section. Simulated heads in cells representing four wells downgradient from the drainfield ranged from $1 \mathrm{ft}$ higher to $4 \mathrm{ft}$ lower than measured heads. The cross-sectional flow model was not calibrated further because the intent was not to exactly reproduce distribution of head but to permit a reasonable, simplified representation of flow and transport. The calibrated injection rate represented underflow was $7,000 \mathrm{ft}^{3} /$ day for each cell.

Flow model results - Simulated flow through the ARG cross-sectional model moved from south to north. A flux of $609,000 \mathrm{ft}^{3} /$ day moved out of the model at the downgradient constant-head boundary, representing flow out of a 6,000-ft wide strip of the ARG deposits into the area of influence of the Ridgecrest well field. For comparison, the annual withdrawal for all COA municipal wells for 2000 was estimated to be 110,000 acre- $\mathrm{ft}$, or 13.1 million $\mathrm{ft}^{3} / \mathrm{day}$. The simplified model of ARG groundwater flow represents less than 5\% of total COA withdrawals. This representation is considered to be reasonable, given known distribution of head, hydraulic conductivity values, and water-withdrawal data.

MT3DMS transport assumptions - Numerical results from the cross-sectional flow model were used to evaluate the downgradient dilution of a solute in groundwater injected into cell 56 (estimated endpoint of a flowpath from TA-V). The following assumptions were made:

- The solute was nonsorptive, moving with groundwater. This assumption was conservative with respect to TCE in an alluvial aquifer that may contain organic carbon.

- The solute did not degrade. This assumption again was conservative with respect to environments prone to biodegradation.

- The solute entered the ARG, with underflow from the alluvial-fan lithofacies to the east, at a concentration that represented relative solute flux from the alluvial-fan cross-section. This solute-bearing underflow across the 600 -ft long cell was simulated by well injection in cell 56 at a concentration representing the flux of contaminant from the alluvial-fan cross-sectional model.

- Solute injected into cell 56 was assumed to mix completely with water in the cell. This mixing is more likely to occur downgradient along the flowpath. The assumption is not considered to be conservative with respect to downgradient concentrations but provides a qualitative assessment of the overall effect of dilution in the ARG.

- Solute was added to cell 56 in underflow for 45 years based on attenuated solute concentrations derived from the alluvial-fan cross-sectional model. Solute influx was proportioned to represent changing concentrations in the last cell of the alluvial-fan model.

- Porosity, required for transport simulation, was assumed to be $25 \%$. This was a reasonable and accepted value used in the regional model. 
The cumulative effect of these assumptions again was to provide a conservative estimate of dilution of downgradient concentrations over time as underflow from the low permeability alluvial-fan lithofacies leached into the ARG.

Transport simulation results - The model indicated that the contaminant pulse would move northward along the ARG cross-section with groundwater flow. The simulated distribution of solute in the aquifer after 45 years is shown in Figure 3-4. After 45 years of solute contribution from the alluvial-fan cross section, the simulated contaminant plume would extend approximately 14 cells $(8,400 \mathrm{ft})$ downgradient from the point of injection. The maximum concentration would be in a cell approximately 5,000 ft downgradient and would be diluted by almost four orders of magnitude from the concentration first introduced into the alluvial-fan cross-section.

Study 1 consisted of the evaluation of contaminant arrivals at the Ridgecrest production wells. The cross-sectional numerical models, evaluating only the effects of dilution along flowpaths, indicated that the first arrival of contaminants in the Ridgecrest wells would occur approximately 80 years after contaminants were first introduced into the ARG cross-sectional model or approximately 230 years after contaminants were first introduced into the system at TA-V. The peak breakthrough at the downgradient constant head (Ridgecrest well field) would occur 97 years after the first contaminant addition in cell 56 at a concentration less than $0.02 \%$ of the starting TA-V concentration.

\subsubsection{Cross-Sectional Groundwater Flow toward a Potential Production Well Field at Mesa del Sol}

The cross-sectional models were also used to evaluate the Study-2 scenario in which potential Mesa del Sol production wells were completed in ARG deposits directly west of TA-V. In this scenario, the production wells were assumed to be in the same ARG cross-sectional cell that receives flow and contaminants derived from the simulated TA-V alluvial-fan flowpath.

In this scenario, simulated contaminant contributions conservatively would be diluted within the east-west flowpath to $20 \%$ of the initial concentration at TA-V. The pulse would attenuate from a 5-year disposal period to a 45-year period at the point of entry into the ARG. These simulated contaminant concentrations in flow from the alluvial-fan cross section would be further diluted as flow entered the ARG cross-section cell 56, representing the ARG deposits adjacent to the TA-V groundwater flowpath. Based on model results, the maximum simulated concentration in water from cell 56 would occur 28 years after the contaminant first entered the ARG. The diluted concentration would be about $0.03 \%$ of the initial TA-V concentration. This scenario assumes either that the contaminant concentration is equally distributed throughout the cell or that all water from the TA-V flow path lies within the Mesa del Sol capture zone. Again, this scenario represents a conservative analysis because it assumes only dilution and does not account for other processes that will occur to further attenuate or degrade contaminants. 


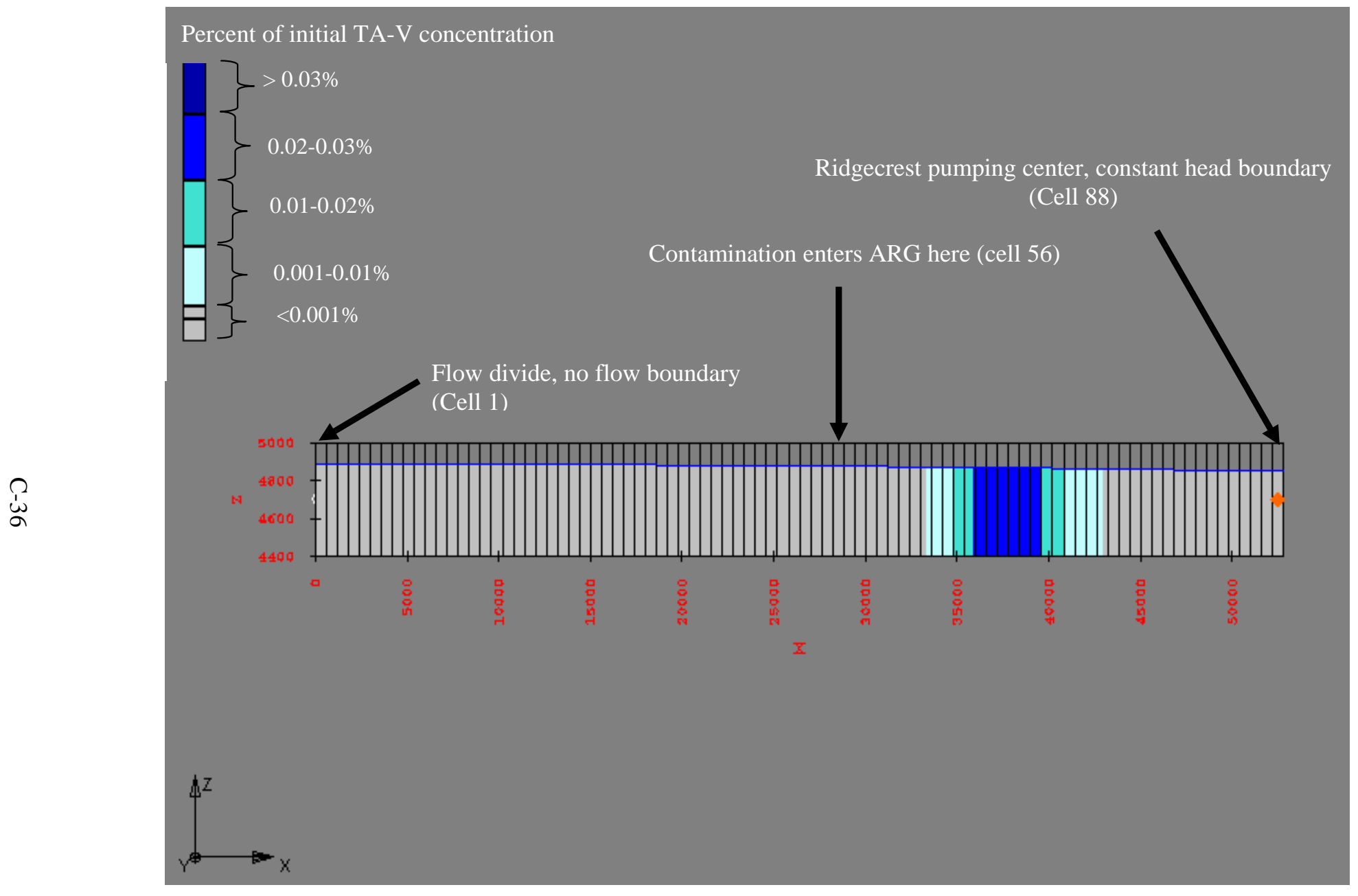

Figure 3-4. Simulated distribution of a contaminant within the simplified ARG south to north cross-sectional groundwater flow model after 45 years of injection (10X vertical exaggeration). 


\subsection{SUMMARY OF NUMERICAL ANALYSES OF GROUNDWATER FLOW AND CONTAMINANT TRANSPORT}

The regional numerical model was initially used to evaluate the dilution factor downgradient from TA-V. The model was not capable of providing a detailed assessment of contaminant dilution. The inconclusive analysis was attributed to the large cell dimensions $(1 \mathrm{~km})$ in the vicinity of TA-V that greatly exceeded the scale of the contaminant plume.

A simplified cross-sectional analysis was used to further assess downgradient contaminant dilution. This two-stage analysis consisted of a cross-section from east to west representing flow from TA-V through the alluvial-fan lithofacies into the ARG lithofacies, and a cross-section from south to north representing accreted flows through the ARG lithofacies toward pumping centers. Hydraulic properties were derived from the regional model. Simulated heads in both sections reasonably matched measured water levels.

A conservative contaminant was injected into the alluvial-fan cross-sectional model to achieve a unit concentration in the cell underlying the contaminant source. The simulated downgradient extent of injected contaminant after 40 years overpredicted the observed contaminant distribution in water from TA-V wells and the rate of contaminant migration because the model did not account for anomalously low hydraulic conductivity in the vicinity of TA-V and for contaminant sorption, decay, or lateral dispersion.

Simulated contaminant concentrations were diluted by a factor of 5 within the 10,000-ft section, representing alluvial-fan sediments downgradient from the TA-V source area (Figure 4-1). The contaminant travel time through the alluvial-fan lithofacies, based on the hydraulic conductivity of $8 \mathrm{ft} /$ day, is estimated to be at least 150 years. Peak concentration breakthrough into the ARG deposits occurs 180 years after release at TA-V. Lower values of hydraulic conductivity, as estimated from contaminant first arrival data, will extend contaminant travel time. The concentration pulse introduced during the 5-year disposal time was attenuated to approximately 45 years at the downgradient end of the section.

The ARG cross-sectional model results indicate that contaminant concentrations would be further diluted as they are leached into the ARG lithofacies. A conservative estimate of dilution may approach four orders of magnitude along the flowpath (Figure 4-1). The minimum travel time of groundwater and conservative solutes from TA-V to the Ridgecrest well field is estimated to be 230 years (Figure 4-1), under assumptions of the model.

Based on this conservative analysis and known COC concentrations in TA-V groundwater, peak TCE and other COC concentrations (PCE and nitrate) at downgradient receptors will be orders of magnitude below their respective MCLs. Further reduction in VOC concentrations is expected to occur from contaminant degradation, sorption, or lateral dispersion. 


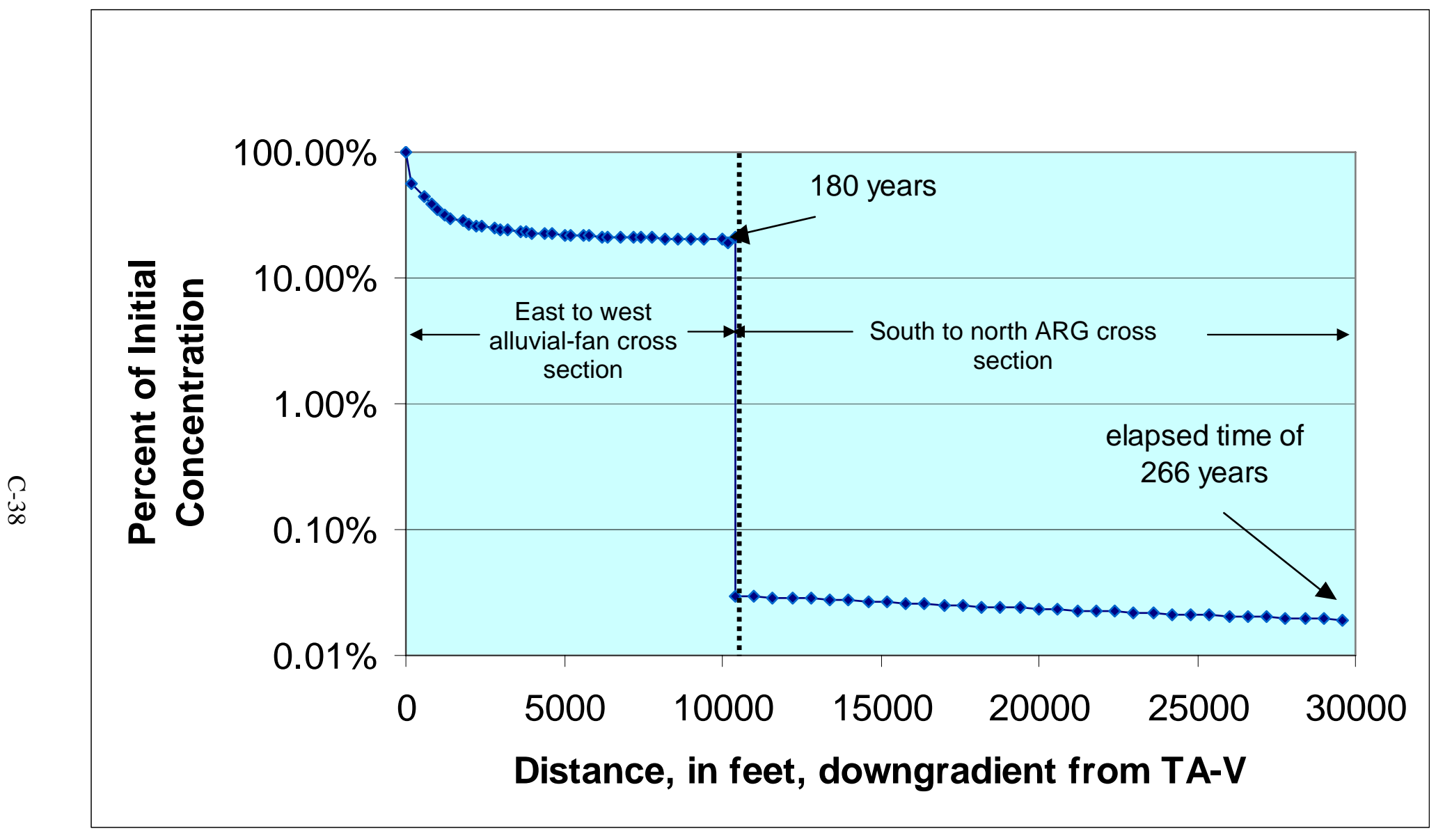

Figure 4-1. Relative peak contaminant concentrations along the east-to-west alluvial-fan and south-to-north ARG flowpaths from TA-V to the Ridgecrest well field. 


\subsection{REFERENCES CITED}

Bartolino, J.R., and J.C. Cole, 2002, “Groundwater Resources of the Middle Rio Grande Basin,” U.S. Geological Survey, Circular 1222, http://water.usgs.gov/pubs/circ/2002/circ1222/.

Bexfield, L.M., and Anderholm, S.K., 2000, "Predevelopment water-level map of the Santa Fe Group aquifer system in the Middle Rio Grande Basin between Cochiti Lake and San Acacia, New Mexico,” U.S. Geological Survey Water-Resources Investigations Report 00-4249, 1 map sheet with text, scale approximately 1:400,000.

Bexfield, L.M., and D.P. McAda, 2003, “Simulated effects of ground-water management scenarios on the Santa Fe Group Aquifer System, Middle Rio Grande Basin, New Mexico, 2001-40,” U.S. Geological Survey Water-Resources Investigations Report 034040, 39 p.

BYU, 2003, Department of Defense Groundwater Modeling System, Version 4.0, developed by the Environmental Modeling Research Laboratory at Brigham Young University for the U.S. Department of Defense, Army Corps of Engineers Waterways Experiment Station, Vicksburg, Mississippi. See http://chl.wes.army.mil/software/gms and http://www.emrl.byu.edu/gms.htm.

Hall, K.A., D.L. Dettmers, and P.S. Lebow, 2004, Corrective Measures Evaluation Work Plan Technical Area-V Groundwater, Sandia Report SAND2004-1471, April 2004.

Harbaugh, A.W., E.R. Banta, M.C. Hill, and M.G. McDonald, 2000, MODFLOW-2000, the U.S. Geological Survey Modular Ground-Water Model-User guide to modularization concepts and the ground-water flow process, Open-File Report 00-92, U.S. Geological Survey, Branch of Information Services, Box 25286, Denver, CO 80225-0425 or http://water.usgs.gov/software/ground_water.html/.

Kalstrom, K.E., S.M. Cather, S.A. Kelley, M.T. Heizler, F.J. Pazzaglia, and M. Roy, 1999, "Sandia Mountains and Rio Grande Rift-Ancestry of Structures and History of Deformation,” in Albuquerque Geology, New Mexico Geological Society $50^{\text {th }}$ Annual Field Conference Guidebook, pp. 155-165.

McAda, D.P., and Barroll, Peggy, 2002, "Simulation of ground-water flow in the Middle Rio Grande Basin between Cochiti and San Acacia, New Mexico,” U.S. Geological Survey Water-Resources Investigations Report 02-4200, 72 p.

NMED, 2003, "Compliance Order on Consent Pursuant to the New Mexico Hazardous Waste Act,” § 74-4-10, Draft Final, New Mexico Environment Department, December 16, 2003.

Orr, B.R., and D.L. Dettmers, 2004, Current Conceptual Model of Groundwater Flow and Contaminant Transport at Sandia National Laboratories/New Mexico Technical Area V, Sandia Report SAND2004-1470, April 2004. 
Pazzaglia, F.J., L.A. Woodward, S.G. Lucas, O.J. Anderson, K.W. Wegmann, and J.W. Estep, 1999, "Phanerozoic Geological Evolution of the Albuquerque Area," in Albuquerque Geology, New Mexico Geological Society $50^{\text {th }}$ Annual Field Conference Guidebook, pp. 97-114.

Ruskauff, Greg, 2004, Modifications to and use of the Middle Rio Grande Model (WRIR 02-4200) for mixing analysis, Technical Memorandum to Sue Collins written November 10, 2004.

SNL/NM, 1998, "SNL/NM Site-Wide Hydrogeologic Characterization Project Calendar Year 1995 Annual Report,” Revised February 1998, Environmental Restoration Program, Sandia National Laboratories/New Mexico, Albuquerque, NM.

SNL/NM, 1999, "SNL/NM Summary Report of Groundwater Investigations at Technical Area V, Operable Units 1306 and 1307,” Environmental Restoration Project, U.S. Department of Energy, Albuquerque Operations Office, Sandia National Laboratories/New Mexico, March 1999.

SNL/NM, 2000, “Annual Groundwater Monitoring Report, Fiscal Year 2000,” Groundwater Protection Program Report 75-1077-3, Sandia National Laboratories/New Mexico, Albuquerque, NM.

SNL/NM, 2001, "SNL/NM Environmental Restoration Project Long-Term Monitoring Strategy for Groundwater,” Environmental Restoration Project, U.S. Department of Energy, Albuquerque Operations Office, Sandia National Laboratories/New Mexico, February 2001.

Van Hart, D., 2003, "Geologic Investigation: An Update of Subsurface Geology on Kirtland Air Force Base, New Mexico,” SAND2003-1869, Sandia National Laboratories, June 2003.

Zheng, C., and P.P. Wang, 1999, "MT3DMS, A Modular Three-Dimensional Multispecies Transport Model”, U.S. Army Corps of Engineers, Strategic Environmental Research and Development Program (SERDP). 
Attachment D

Investigation of Contaminant Biodegradation

D-1 
This Page Intentionally Left Blank

C-2 


\section{Investigation of Intrinsic Anaerobic Biodegradation in Technical Area-V Groundwater at Sandia National Laboratories/New Mexico}

July 2004

Prepared by

Sandia National Laboratories

Albuquerque, New Mexico 87185 and Livermore, California 94550

Sandia is a multiprogram laboratory operated by Sandia Corporation,

a Lockheed Martin Company, for the United States Department of Energy's

National Nuclear Security Administration under Contract DE-AC04-94AL85000.

Approved for public release; further dissemination unlimited.

1.7. Sandia National Laboratories 


\section{CONTENTS}

1.0 .

INTRODUCTION

2.0 . CONTAMINANT BIODEGRADATION ASSESSMENT DATA

3.0 . CONTAMINANT BIODEGRADATION SCREENING ASSESSMENT

3.1 VOC Biodegradation Screening Assessment Process .............................................9

3.2 TA-V VOC Biodegradation Screening Assessment and Results ...........................11

3.3 TA-V Nitrate Biodegradation Screening Assessment and Results........................14

4.0................................................................. CONCLUSIONS AND RECOMMENDATIONS 15

5.0

REFERENCES 16

Appendix A. FY 2004 Quarters 1 and 2 Biodegradation Assessment Data

\section{TABLES}

2-1. Parameters for assessment of contaminant biodegradation.

3-1. Analytical Parameters and Scoring for Anaerobic Biodegradation Screening Assessment Processes (modified from EPA 1998)........................................................................... 9

3-2. Interpretation of Points Awarded During Screening. .......................................................... 10

3-3. Anaerobic VOC biodegradation screening for TA-V wells. ............................................... 12 


\subsection{INTRODUCTION}

The "Corrective Measures Evaluation Work Plan Technical Area-V Groundwater" (SNL/NM 2004a) was prepared as directed by the Compliance Order on Consent (COOC) issued by the New Mexico Environment Department (NMED) (NMED 2004). This work plan outlines a process for evaluation of remedial alternatives, the Remedial Alternative Evaluation Plan, in order to identify a corrective measure for the Contaminants of Concern (COCs) in Sandia National Laboratories/New Mexico Technical Area-V (TA-V) Groundwater. The COCs at TAV include nitrate and two volatile organic compounds (VOCs), trichloroethene (TCE) and tetrachloroethene (PCE). The Remedial Alternative Evaluation Plan identifies data gathering activities to be carried out in four stages. These stages consist of the paper study, numerical modeling, laboratory studies, and field scale studies. This paper documents the results of a biodegradation screening assessment, which is a field scale study activity.

Sampling at TA-V is conducted by SNL/NM's Environmental Restoration Project as part of a voluntary monitoring program. Some data for assessment of contaminant biodegradation are collected under this current monitoring program. Additional sampling work was performed under the Sandia National Laboratories TA-V Groundwater Remediation Sampling and Analysis Plan (Dettmers and Wymore 2003), referred to as the TA-V Groundwater Remediation SAP. The purpose of the additional sampling was to collect appropriate analytes during one or more quarterly TA-V groundwater sampling event(s) to provide adequate data for a VOC anaerobic biodegradation screening assessment, as defined by the Technical Protocol for Evaluating Natural Attenuation of Chlorinated Solvents in Ground Water (EPA 1998), and for an assessment of the potential for nitrate biodegradation via denitrification.

The purpose of this document is to present the biodegradation screening assessment for VOCs and nitrate at TA-V. The data used to perform this assessment are presented in Section 2.0 and Appendix A, the anaerobic biodegradation screening assessment is presented in Section 3.0, and conclusions are presented in Section 4.0. 


\subsection{CONTAMINANT BIODEGRADATION ASSESSMENT DATA}

Water samples were collected under the TA-V Groundwater Remediation SAP during the first(November 17 to December 4, 2003) and second- (March 29 to April 16, 2004) quarter sampling rounds of Fiscal Year (FY) 2004. These samples were collected in conjunction with the current voluntary monitoring program. Sampling and analyses conducted under the TA-V Groundwater Remediation SAP included monitoring for analytes that had not been included in the past during voluntary monitoring activities. First-quarter sampling was conducted using low-flow methods and second-quarter sampling was conducted using conventional sampling methods with a Bennett Pump.

The significance of each parameter to an assessment of degradation potential is explained in Table 2-1 along with observations from the data set presented in Appendix A. Data collected as part of the current voluntary monitoring program that will be used in the assessment of contaminant biodegradation include: VOCs (PCE, TCE, cis-1,2-DCE, trans-1,2-DCE, and VC), nitrate (as nitrogen), nitrate plus nitrite (as nitrogen), chloride, sulfate, alkalinity, oxidation reduction potential (ORP), dissolved oxygen (DO), $\mathrm{pH}$, and temperature. Additional data collected under the TA-V Groundwater Remediation SAP include: ethane, ethene, methane, dissolved organic carbon (DOC), chemical oxygen demand (COD), ammonia (as nitrogen), orthophosphate (as phosphorous), manganese II, carbon dioxide, and ferrous iron. The FY-04 first- and second-quarter sampling results for all these analyses are presented in Appendix A. All $\mathrm{QA} / \mathrm{QC}$ requirements, as stated in the TA-V Groundwater Remediation SAP, were met. 
Table 2-1. Parameters for assessment of contaminant biodegradation.

\begin{tabular}{|c|c|c|c|}
\hline Parameters & Data Relevance & Data Observation & $\begin{array}{c}\text { Table in } \\
\text { Appendix A }\end{array}$ \\
\hline $\begin{array}{l}\text { VOCs (PCE, TCE, } \\
\text { cis-1,2-DCE, trans- } \\
1,2-D C E \text {, and VC) }\end{array}$ & $\begin{array}{l}\text { Contaminants and dechlorination } \\
\text { products; required to assess } \\
\text { chlorinated solvent biodegradation }\end{array}$ & $\begin{array}{l}\text { TCE was detected above the MCL of } 5 \mu \mathrm{g} / \mathrm{L} \text { at LWDS-MW1 during both } \\
\text { quarters (15.1-18.2 } \mu \mathrm{g} / \mathrm{L}) \text { and at TAV-MW8 during the first quarter (7.16 } \\
\mu \mathrm{g} / \mathrm{L}) \text {. Detection of TCE below the MCL was observed at TAV-MW1, TAV- } \\
\text { MW4, and TAV-MW6 during both quarters and at TAV-MW8 during the } \\
\text { second quarter. Detection of cis-DCE below the MCL was observed at LWDS- } \\
\text { MW1 during both quarters and at TAV-MW8 during the first quarter. Detection } \\
\text { of PCE below the MCL was observed at TAV-MW7 during the first quarter. All } \\
\text { other results for all wells were below the MDL for all VOCs. }\end{array}$ & Table A-1 \\
\hline $\begin{array}{l}\text { Nitrate (as } \\
\text { nitrogen) }\end{array}$ & $\begin{array}{l}\text { Contaminant (compliance } \\
\text { requirement) and redox parameter }\end{array}$ & $\begin{array}{l}\text { Nitrate was detected above the MCL of } 10 \mathrm{mg} / \mathrm{L} \text { at LWDS-MW1 }(12.0 \mathrm{mg} / \mathrm{L} \\
\text { for nitrate and } 12.0-15.0 \mathrm{mg} / \mathrm{L} \text { for nitrate plus nitrite). All other wells had } \\
\text { nitrate detections below the MCL. }\end{array}$ & Table A-2 \\
\hline Ethene/Ethane & $\begin{array}{l}\text { Dechlorination products; required to } \\
\text { determine effectiveness of chlorinated } \\
\text { solvent biodegradation }\end{array}$ & All ethane and ethene results were below the MDL. & Table A-4 \\
\hline Chloride & $\begin{array}{l}\text { Dechlorination product; released } \\
\text { during chlorinated solvent } \\
\text { biodegradation }\end{array}$ & Chloride results are similar to historic average concentrations for each well. & Table A-4 \\
\hline DOC and COD & $\begin{array}{l}\text { Surrogate measure for bioavailable } \\
\text { electron donor }\end{array}$ & $\begin{array}{l}\text { DOC is present in all samples at less than } 2 \mathrm{mg} / \mathrm{L} \text {. COD is not consistently } \\
\text { present in each well between quarters and ranged from below the MDL to } 29.2 \\
\text { mg/L. In general, COD is less than } 20 \mathrm{mg} / \mathrm{L} \text {. }\end{array}$ & Table A-4 \\
\hline Ferrous Iron & $\begin{array}{l}\text { Redox parameter; electron acceptor } \\
\text { (ferric iron) is reduced to the product } \\
\text { (ferrous iron); required to assess } \\
\text { active anaerobic reaction pathways }\end{array}$ & $\begin{array}{l}\text { Ferrous iron was below the MDL for all samples except it was detected during } \\
\text { the second quarter at TAV-MW7 and TAV-MW9 }(0.06 \mathrm{mg} / \mathrm{L}) \text {. }\end{array}$ & Table A-3 \\
\hline Manganese II & $\begin{array}{l}\text { Redox parameter; required to assess } \\
\text { active anaerobic oxidation pathways }\end{array}$ & All manganese II results were below the MDL. & Table A-3 \\
\hline Sulfate & $\begin{array}{l}\text { Redox parameter; electron acceptor; } \\
\text { required to assess active anaerobic } \\
\text { reaction pathways }\end{array}$ & Sulfate results are similar to historic average concentrations for each well. & Table A-3 \\
\hline
\end{tabular}


Table 2-1. (continued).

\begin{tabular}{|c|c|c|c|}
\hline Parameters & Data Significance & Data Observation & $\begin{array}{c}\text { Table in } \\
\text { Appendix A }\end{array}$ \\
\hline Methane & $\begin{array}{l}\text { Redox parameter; required to assess } \\
\text { active anaerobic reaction pathways }\end{array}$ & Methane was not detected above $2.30 \mu \mathrm{g} / \mathrm{L}$. & Table A-3 \\
\hline ORP & $\begin{array}{l}\text { Redox parameter; required to assess } \\
\text { active anaerobic reaction pathways }\end{array}$ & ORP ranged between 52.4 to $274.1 \mathrm{mV}$. & Table A-6 \\
\hline DO & $\begin{array}{l}\text { Redox parameter; required to assess } \\
\text { active anaerobic reaction pathways }\end{array}$ & DO ranged between 0.46 to $8.19 \mathrm{mg} / \mathrm{L}$. & Table A-6 \\
\hline Orthophosphate & $\begin{array}{l}\text { Microbial nutrient; required to assess } \\
\text { potential nutrient limitations }\end{array}$ & All orthophosphate results were below the MDL. & Table A-5 \\
\hline $\begin{array}{l}\text { Ammonia } \\
\text { (as nitrogen) }\end{array}$ & $\begin{array}{l}\text { Microbial nutrient; required to assess } \\
\text { potential nutrient limitations }\end{array}$ & $\begin{array}{l}\text { All ammonia results were below the MDL except for one detection at AVN-2 of } \\
0.040 \mathrm{mg} / \mathrm{L} \text {. }\end{array}$ & Table A-5 \\
\hline Carbon Dioxide & $\begin{array}{l}\text { Indicator of microbial respiration; } \\
\text { may be useful for evaluating } \\
\text { biostimulation }\end{array}$ & Carbon dioxide concentrations ranged from $200 \mathrm{mg} / \mathrm{L}$ to $480 \mathrm{mg} / \mathrm{L}$. & Table A-5 \\
\hline Alkalinity & $\begin{array}{l}\text { Indicator of microbial respiration; } \\
\text { may be useful for evaluating } \\
\text { biostimulation }\end{array}$ & Alkalinity results ranged from 124 to $221 \mathrm{mg} / \mathrm{L}$. & Table A-5 \\
\hline $\begin{array}{l}\mathrm{pH} \text { and } \\
\text { Temperature }\end{array}$ & $\begin{array}{l}\text { Water quality parameters; may be } \\
\text { useful for evaluating biostimulation } \\
\text { and suitability of conditions for } \\
\text { anaerobic reductive dechlorination }\end{array}$ & $\begin{array}{l}\text { The range for } \mathrm{pH} \text { was from } 7.18 \text { to } 8.39 \text {. Temperature ranged from } 14.78 \text { to } \\
21.1^{\circ} \mathrm{C} \text {. }\end{array}$ & Table A-6 \\
\hline \multicolumn{4}{|c|}{$\begin{array}{l}\mathrm{mg} / \mathrm{L}=\text { milligrams per liter, } \mu \mathrm{g} / \mathrm{L}=\text { micrograms per liter } \\
\mathrm{mV}=\text { millivolt } \\
{ }^{\circ} \mathrm{C}=\text { degrees Celsius }\end{array}$} \\
\hline \multicolumn{2}{|c|}{$\begin{array}{l}\text { COD = chemical oxygen demand } \\
\text { DCE = dichloroethene } \\
\text { DO = dissolved oxygen } \\
\text { DOC = dissolved organic carbon } \\
\text { MCL = maximum contaminant level } \\
\text { MDL = method detection limit }\end{array}$} & $\begin{array}{l}\text { idation reduction potential } \\
\text { achloroethene } \\
\text { hloroethene } \\
\text { l chloride } \\
\text { latile organic compound }\end{array}$ & \\
\hline
\end{tabular}




\subsection{CONTAMINANT BIODEGRADATION SCREENING ASSESSMENT}

The contaminant biodegradation assessment data, presented in Section 2.0 and Appendix A, and historical TA-V data were used to perform the VOC contaminant biodegradation screening assessment described in the Technical Protocol for Evaluating Natural Attenuation of Chlorinated Solvents in Ground Water (EPA 1998). This section details the VOC biodegradation screening assessment process (Section 3.1) and performs the biodegradation screening using data from TA-V wells (Section 3.2). An assessment of nitrate biodegradation is presented in Section 3.3.

\subsection{VOC Biodegradation Screening Assessment Process}

The purpose of this screening is to determine if evidence is available to show that anaerobic biodegradation of VOCs is occurring in TA-V groundwater. Anaerobic biodegradation of VOCs occurs through a process called reductive dechlorination. This biodegradation screening assessment process consists of analyzing the data using the information presented in Table 3-1. For each parameter, a concentration criterion, interpretation of the criterion, and a scoring value are listed. For the performance and sentry wells at TA-V, a value was assigned for each parameter. The TA-V background wells were used as a basis of comparison for some of the parameters. The total scoring value for all parameters at each well was compared to the interpretation information presented in Table 3-2.

Table 3-1. Analytical Parameters and Scoring for Anaerobic Biodegradation Screening Assessment Processes (modified from EPA 1998).

\begin{tabular}{|c|c|c|c|}
\hline Parameters & $\begin{array}{l}\text { Concentration in } \\
\text { Most Contaminated } \\
\text { Zone }\end{array}$ & Interpretation & Score \\
\hline \multirow[t]{2}{*}{ Oxygen } & $<0.5 \mathrm{mg} / \mathrm{L}$ & $\begin{array}{l}\text { Tolerated, suppresses the reductive pathway } \\
\text { at higher concentrations }\end{array}$ & 3 \\
\hline & $>5 \mathrm{mg} / \mathrm{L}$ & $\begin{array}{l}\text { Not tolerated; however, VC may be } \\
\text { oxidized aerobically }\end{array}$ & -3 \\
\hline Nitrate & $<1 \mathrm{mg} / \mathrm{L}$ & $\begin{array}{l}\text { At higher concentrations may compete with } \\
\text { reductive pathway }\end{array}$ & 2 \\
\hline Iron II & $>1 \mathrm{mg} / \mathrm{L}$ & $\begin{array}{l}\text { Reductive pathway possible; VC may be } \\
\text { oxidized under Fe (III)-reducing conditions }\end{array}$ & 3 \\
\hline Sulfate & $<20 \mathrm{mg} / \mathrm{L}$ & $\begin{array}{l}\text { At higher concentrations may compete with } \\
\text { reductive pathway }\end{array}$ & 2 \\
\hline Methane & $\begin{array}{l}<0.5 \mathrm{mg} / \mathrm{L} \\
>0.5 \mathrm{mg} / \mathrm{L}\end{array}$ & $\begin{array}{l}\text { VC oxidizes } \\
\text { Indicator of methanogenic conditions; VC } \\
\text { Accumulates }\end{array}$ & $\begin{array}{l}0 \\
3\end{array}$ \\
\hline $\begin{array}{l}\text { ORP against } \\
\text { Ag/AgCl } \\
\text { electrode }\end{array}$ & $\begin{array}{l}<50 \mathrm{mV} \\
<-100 \mathrm{mV}\end{array}$ & $\begin{array}{l}\text { Reductive pathway possible } \\
\text { Reductive pathway likely }\end{array}$ & 1 \\
\hline $\mathrm{pH}$ & $\begin{array}{l}5<\mathrm{pH}<9 \\
\mathrm{pH}<5 \text { or } \mathrm{pH}>9\end{array}$ & $\begin{array}{l}\text { Optimal range for reductive pathway } \\
\text { Outside optimal range for reductive } \\
\text { pathway }\end{array}$ & $\begin{array}{l}0 \\
-2\end{array}$ \\
\hline
\end{tabular}

D-9 
Table 3-1. (continued).

\begin{tabular}{|c|c|c|c|}
\hline Parameters & $\begin{array}{l}\text { Concentration in } \\
\text { Most Contaminated } \\
\text { Zone }\end{array}$ & Interpretation & Value \\
\hline TOC & $>20 \mathrm{mg} / \mathrm{L}$ & $\begin{array}{l}\text { Carbon and energy source; drives } \\
\text { dechlorination; can be natural or } \\
\text { anthropogenic }\end{array}$ & 2 \\
\hline Temperature & $>20^{\circ} \mathrm{C}$ & $\begin{array}{l}\text { At } \mathrm{T}>20^{\circ} \mathrm{C} \text { biochemical process is } \\
\text { accelerated }\end{array}$ & 1 \\
\hline Carbon Dioxide & $>2 \mathrm{x}$ background & Ultimate oxidative daughter product & 1 \\
\hline Alkalinity & $>2 x$ background & $\begin{array}{l}\text { Results from interaction between } \mathrm{CO}_{2} \text { and } \\
\text { aquifer minerals }\end{array}$ & 1 \\
\hline Chloride & $>2 x$ background & Daughter product of organic chlorine & 2 \\
\hline BTEX & $>0.1 \mathrm{mg} / \mathrm{L}$ & $\begin{array}{l}\text { Carbon and energy source; drives } \\
\text { dechlorination }\end{array}$ & 2 \\
\hline PCE & Not Applicable & Material release & 0 \\
\hline TCE & Not Applicable & $\begin{array}{l}\text { Material release } \\
\text { Daughter product of PCE }\end{array}$ & 0 \\
\hline$\overline{\mathrm{DCE}}$ & Not Applicable & $\begin{array}{l}\text { Material release } \\
\text { Daughter product of TCE } \\
\text { If cis is }>80 \% \text { of total DCE it is likely a } \\
\text { daughter product of 1,1-DCE can be } \\
\text { chemical reaction product of TCA }\end{array}$ & $\begin{array}{l}0 \\
2 *\end{array}$ \\
\hline VC & Not Applicable & $\begin{array}{l}\text { Material release } \\
\text { Daughter product of DCE }\end{array}$ & $\begin{array}{l}0 \\
2 * \\
\end{array}$ \\
\hline Ethene/Ethane & $\begin{array}{l}>0.01 \mathrm{mg} / \mathrm{L} \\
>0.1 \mathrm{mg} / \mathrm{L}\end{array}$ & Daughter product of VC/ethene & $\begin{array}{l}2 \\
3 \\
3\end{array}$ \\
\hline \multicolumn{4}{|c|}{$\begin{array}{l}\text { *Points awarded only if it can be shown that the compound is a daughter product. } \\
\mathrm{mg} / \mathrm{L}=\text { milligrams per liter } \\
\mathrm{mV}=\text { millivolt } \\
{ }^{\circ} \mathrm{C}=\text { degrees Celsius }\end{array}$} \\
\hline $\begin{array}{l}\text { BTEX }=\text { benzene, tolue } \\
\text { DCE = dichloroethene } \\
\text { ORP = oxidation reduc } \\
\text { PCE = tetrachloroethen }\end{array}$ & , ethyl benzene, xylene & $\begin{array}{l}\text { TCE }=\text { trichloroethene } \\
\text { TOC = total organic carbon } \\
\text { VC = vinyl chloride }\end{array}$ & \\
\hline
\end{tabular}

Table 3-2. Interpretation of Points Awarded During Screening.

\begin{tabular}{l|l}
\hline \multicolumn{1}{c|}{ Score } & \multicolumn{1}{c}{ Interpretation } \\
\hline 0 to 5 & Inadequate evidence for anaerobic biodegradation (reductive dechlorination) \\
\hline 6 to 14 & Limited evidence for anaerobic biodegradation (reductive dechlorination) \\
\hline 15 to 20 & Adequate evidence for anaerobic biodegradation (reductive dechlorination) \\
\hline$>20$ & Strong evidence for anaerobic biodegradation (reductive dechlorination) \\
\hline
\end{tabular}

D-10 


\subsection{TA-V VOC Biodegradation Screening Assessment and Results}

The biodegradation screening was performed for the performance and sentry wells at TA-V. Performance wells at TA-V include LWDS-MW1, TAV-MW1, TAV-MW2, TAV-MW4, TAVMW6, TAV-MW7, TAV-MW8, and TAV-MW9. Sentry wells include TAV-MW5 and LWDSMW2. Groundwater monitoring data from wells TAV-MW3 and AVN-2 were used to represent background conditions. When available, historical data along with the most recent data were analyzed against the evaluation criteria (Table 3-1) in order to make general assessments of conditions within each well.

Table 3-3 summarizes the results of the VOC biodegradation screening assessment. This table presents a scoring value for each parameter at each well and a general explanation for the scoring value assignments. The total scoring value for each well is also shown. Total scores range from -2 to 4 . Comparisons of these total values to the interpretations of the values presented in Table 3-2 show that all wells fall within or below the scoring range of 0 to 5 . Although, not part of the screening assessment presented in the protocol (EPA 1998), the nutrients ammonia (nitrogen) and orthophosphate (phosphorus) were also not present in the TA-V groundwater samples demonstrating the oligotrophic nature of the aquifer.

The results of the biodegradation screening assessment demonstrate that anaerobic reductive dechlorination is not a significant process contributing to natural attenuation of VOCs. Although, the presence of cis-DCE suggests that anaerobic reductive dechlorination may have occurred in the past, there is inadequate evidence to demonstrate that biodegradation, through anaerobic processes of reductive dechlorination, is now occurring in TA-V groundwater.

D-11 
Table 3-3. Anaerobic VOC biodegradation screening for TA-V wells.

\begin{tabular}{|c|c|c|c|c|c|c|c|c|c|c|c|}
\hline \multirow[b]{2}{*}{ Parameters } & \multicolumn{8}{|c|}{ Performance Wells } & \multicolumn{2}{|c|}{$\begin{array}{l}\text { Sentry } \\
\text { Wells }\end{array}$} & \multirow[b]{2}{*}{ Reason for Scoring } \\
\hline & 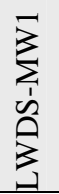 & $\sum_{\substack{1 \\
\mid}}^{\sum_{1}^{-1}}$ & $\sum_{\substack{1 \\
\mid}}^{\sum_{1}}$ & $\sum_{\substack{1 \\
\mid}}^{\sum_{1}^{+}}$ & $\sum_{\substack{1 \\
\leqslant}}^{\infty}$ & $\sum_{\substack{1 \\
\sum}}^{\sum_{1}}$ & $\sum_{\substack{1 \\
\leqslant}}^{\infty}$ & $\sum_{\substack{1 \\
\sum_{1}}}^{\infty}$ & $\sum_{\substack{1 \\
\mid}}^{\infty}$ & $\begin{array}{l}\sum_{j=1}^{N} \\
\sum_{1}^{1} \\
3\end{array}$ & \\
\hline Oxygen & -3 & -3 & -3 & -3 & -3 & 3 & -3 & 0 & 0 & -3 & $\begin{array}{l}\text { Wells with DO concentrations }>5 \mathrm{mg} / \mathrm{L} \text { received a score of }-3 \text {. Only well TAV- } \\
\text { MW7 showed the possibility of being anaerobic with a recent concentration that } \\
\text { was }<0.5 \mathrm{mg} / \mathrm{L} \text {. }\end{array}$ \\
\hline Nitrate & 0 & 0 & 0 & 0 & 0 & 0 & 0 & 0 & 0 & 0 & $\begin{array}{l}\text { Nitrate concentrations are greater than } 1 \mathrm{mg} / \mathrm{L} \text { in all wells, and nitrate may } \\
\text { compete with reductive pathway. }\end{array}$ \\
\hline Iron II & 0 & 0 & 0 & 0 & 0 & 0 & 0 & 0 & 0 & 0 & $\begin{array}{l}\text { Ferrous iron has not been detected in any wells }>1 \mathrm{mg} / \mathrm{L} \text {. Manganese II, another } \\
\text { indicator of reducing conditions, was also below MDL in all samples. }\end{array}$ \\
\hline Sulfate & 0 & 0 & 0 & 0 & 0 & 0 & 0 & 0 & 0 & 0 & $\begin{array}{l}\text { Sulfate concentrations are }>20 \mathrm{mg} / \mathrm{L} \text { and may compete with the reductive } \\
\text { pathway. }\end{array}$ \\
\hline Methane & 0 & 0 & 0 & 0 & 0 & 0 & 0 & 0 & 0 & 0 & Although methane has been detected in some wells, it has always been $<0.5 \mathrm{mg} / \mathrm{L}$. \\
\hline ORP & 0 & 0 & 0 & 0 & 0 & 0 & 0 & 0 & 0 & 0 & $\begin{array}{l}\text { ORP is generally greater than } 50 \mathrm{mV} \text { in all wells suggesting that a reductive } \\
\text { pathway is not possible. }\end{array}$ \\
\hline $\mathrm{pH}$ & 0 & 0 & 0 & 0 & 0 & 0 & 0 & 0 & 0 & 0 & $\begin{array}{l}\text { The } \mathrm{pH} \text { in all wells has remained within the optimal range for the reductive } \\
\text { pathway. }\end{array}$ \\
\hline TOC & 0 & 0 & 0 & 0 & 0 & 0 & 0 & 0 & 0 & 0 & $\begin{array}{l}\text { Very low DOC concentrations }(<2 \mathrm{mg} / \mathrm{L}) \text { from FY-04 monitoring and low TOC } \\
\text { concentrations }(<4 \mathrm{mg} / \mathrm{L}) \text { from historical groundwater monitoring (SNL/NM } \\
\text { 2004b) suggest that organic carbon is limited. }\end{array}$ \\
\hline Temperature & 1 & 1 & 1 & 1 & 1 & 1 & 1 & 1 & 1 & 1 & $\begin{array}{l}\text { During seasonal temperature variations, the groundwater temperature has been } \\
>20^{\circ} \mathrm{C} \text {. }\end{array}$ \\
\hline $\begin{array}{l}\text { Carbon } \\
\text { Dioxide }\end{array}$ & 0 & 0 & 0 & 0 & 0 & 0 & 0 & 0 & 0 & 0 & $\begin{array}{l}\text { Carbon dioxide concentrations are less than two times the concentration in the } \\
\text { background wells, TAV-MW3 and AVN-2. }\end{array}$ \\
\hline Alkalinity & 0 & 0 & 0 & 0 & 0 & 0 & 0 & 0 & 0 & 0 & Alkalinity is less than two times the concentration in background wells. \\
\hline
\end{tabular}


Table 3-3. (continued).

\begin{tabular}{|c|c|c|c|c|c|c|c|c|c|c|c|}
\hline \multirow[b]{2}{*}{ Parameters } & \multicolumn{8}{|c|}{ Performance Wells } & \multicolumn{2}{|c|}{$\begin{array}{l}\text { Sentry } \\
\text { Wells }\end{array}$} & \multirow[b]{2}{*}{ Reason for Scoring } \\
\hline & $\begin{array}{l}\sum_{\infty}^{1} \\
\sum_{1}^{1} \\
\sum_{1}\end{array}$ & $\sum_{i=1}^{\infty}$ & $\sum_{\substack{1 \\
\qquad}}^{\sum_{1}}$ & $\sum_{\substack{1 \\
\mid}}^{\sum_{1}^{+}}$ & $\sum_{\substack{1 \\
\sum_{1}}}^{\infty}$ & $\sum_{\substack{1 \\
\sum_{1}}}^{\substack{1 \\
H}}$ & $\sum_{\substack{1 \\
\qquad}}^{\infty}$ & 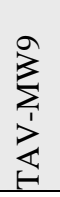 & $\sum_{\substack{1 \\
\sum_{1}}}^{\sum_{1}^{0}}$ & $\begin{array}{l}\sum_{1}^{N} \\
\sum_{1}^{\infty} \\
\sum_{3}^{2} \\
\end{array}$ & \\
\hline Chloride & 0 & 0 & 0 & 0 & 0 & 0 & 0 & 0 & 0 & 0 & $\begin{array}{l}\text { Chloride concentrations are variable in different wells. Although some chloride } \\
\text { concentrations are greater than two times background, chloride is not believed to } \\
\text { be a result of chlorinated organic compound degradation (SNL/NM 2004b). }\end{array}$ \\
\hline BTEX & 0 & 0 & 0 & 0 & 0 & 0 & 0 & 0 & 0 & 0 & $\begin{array}{l}\text { BTEX compound concentrations have remained below } 0.1 \mathrm{mg} / \mathrm{L} \text { at concentrations } \\
\text { that are likely too low to provide a significant carbon or energy source. }\end{array}$ \\
\hline PCE & 0 & 0 & 0 & 0 & 0 & 0 & 0 & 0 & 0 & 0 & PCE in groundwater is a material released from the source. \\
\hline TCE & 0 & 0 & 0 & 0 & 0 & 0 & 0 & 0 & 0 & 0 & $\begin{array}{l}\text { TCE in groundwater is a material released from the source, and is not suspected to } \\
\text { be a degradation product of PCE reduction. }\end{array}$ \\
\hline DCE & 2 & 0 & 0 & 0 & 0 & 0 & 2 & 0 & 0 & 0 & $\begin{array}{l}\text { DCE (cis-DCE) has been detected in LWDS-MW1 and TAV-MW8 and is } \\
\text { believed to be a degradation product from past dechlorination. }\end{array}$ \\
\hline VC & 0 & 0 & 0 & 0 & 0 & 0 & 0 & 0 & 0 & 0 & $\begin{array}{l}\text { VC has only been detected on two occasions in the past. VC has not been detected } \\
\text { recently in any wells. }\end{array}$ \\
\hline Ethene/Ethane & 0 & 0 & 0 & 0 & 0 & 0 & 0 & 0 & 0 & 0 & Ethene and ethane were not detected in any wells. \\
\hline Total Score & $\mathbf{0}$ & -2 & -2 & -2 & -2 & 4 & $\mathbf{0}$ & 1 & 1 & -2 & \\
\hline
\end{tabular}




\section{3 $\quad$ TA-V Nitrate Biodegradation Screening Assessment and Results}

Transformation of nitrate in the environment is part of the natural nitrogen cycle. Under the right environmental conditions, nitrate can be transformed to nitrogen gas through the biologically mediated process of denitrification. Denitrification can occur in low oxygen environments and in the presence of an electron donor where nitrate can act as an electron acceptor in the microbial respiration process (ITRC 2002). Oxygen is a more thermodynamically favorable electron acceptor than nitrate, and in the presence of oxygen aerobically respiring organisms will constitute the dominant microbial community. Dissolved oxygen is therefore inhibitory to the process of denitrification. Denitrification also requires the presence of both carbon and energy sources to sustain biological activity within groundwater.

There is not a biodegradation screening assessment for nitrate like that presented for VOCs (Section 3.2). However, a qualitative evaluation of the data demonstrates that biologically mediated transformation of nitrate is not likely to act as a natural attenuation mechanism in TA$\mathrm{V}$ groundwater. This is confirmed by the following observations:

- Dissolved oxygen inhibits the process of denitrification. Dissolved oxygen concentrations in samples from most of the wells were greater than $5 \mathrm{mg} / \mathrm{L}$. Which is significantly high to inhibit denitrification

- A source of carbon and energy must be available to sustain biological activity. Very low DOC concentrations $(<2 \mathrm{mg} / \mathrm{L})$ and low TOC concentrations $(<4 \mathrm{mg} / \mathrm{L})$ suggest that organic carbon and energy sources are limited.

- Evidence from historical groundwater monitoring suggests that nitrate concentrations are not declining (SNL/NM 2004b). 


\subsection{CONCLUSIONS AND RECOMMENDATIONS}

An anaerobic biodegradation screening assessment was performed for VOCs and nitrate at TA$\mathrm{V}$. The assessment evaluated numerous parameters that are indicative of anaerobic biodegradation of these COCs in groundwater. Based on the screening process, the conclusions of this report are:

1. Conditions in TA-V groundwater are not conducive to anaerobic biodegradation of VOCs; therefore, anaerobic biodegradation is not a significant natural attenuation mechanism.

2. Conditions conducive to denitrification are not present in TA-V groundwater; therefore, natural attenuation via denitrification is not a significant natural attenuation mechanism.

The results of this screening will be used in the TA-V Groundwater CME Report.

D-15 


\subsection{REFERENCES}

4. Dettmers, D.L. and Wymore R.A., October 2003, Sandia National Laboratories TA-V Groundwater Remediation Sampling and Analysis Plan, NW-ID-2003-072, Rev. 0, North Wind, Inc EPA 2000a.

5. EPA, 1998. "Technical Protocol for Evaluating Natural Attenuation of Chlorinated Solvents in Ground Water," United States Environmental Protection Agency, Office of Research and Development, Washington DC.

6. Interstate Technology and Regulatory Cooperation (ITRC) Work Group, 2002. "Technical and Regulatory Guidance for In Situ Bioremediation in Groundwater,” 129 pp.

7. NMED 2004, "Compliance Order on Consent Pursuant to the New Mexico Hazardous Waste Act 74-4-10: Sandia National Laboratories Consent Order,” New Mexico Environment Department, April 24, 2004.

8. SNL/NM, 2004a, "Corrective Measures Evaluation Work Plan Technical Area-V Groundwater,” Sandia National Laboratories/New Mexico.

9. SNL/NM, 2004b, "Current Conceptual Model of Groundwater Flow and Contaminant Transport at Sandia National Laboratories/New Mexico Technical Area V,” Sandia National Laboratories/New Mexico.

D-16 


\section{Appendix A}

FY 2004 Quarters 1 and 2 Biodegradation Assessment Data

D-17 
Table A-1. VOC data.

\begin{tabular}{|c|c|c|c|c|c|c|c|c|c|c|}
\hline & \multicolumn{2}{|c|}{$\begin{array}{c}\text { PCE } \\
(\mu \mathrm{g} / \mathrm{L})\end{array}$} & \multicolumn{2}{|c|}{$\begin{array}{c}\text { TCE } \\
(\mu \mathrm{g} / \mathrm{L})\end{array}$} & \multicolumn{2}{|c|}{$\begin{array}{c}\text { cis-DCE } \\
(\mu \mathrm{g} / \mathrm{L})\end{array}$} & \multicolumn{2}{|c|}{$\begin{array}{c}\text { trans-DCE } \\
(\mu \mathrm{g} / \mathrm{L})\end{array}$} & \multicolumn{2}{|c|}{$\begin{array}{l}\text { Vinyl chloride } \\
(\mu \mathrm{g} / \mathrm{L})\end{array}$} \\
\hline & $\begin{array}{c}1 \mathrm{st} \\
\text { quarter }\end{array}$ & $\begin{array}{l}\text { 2nd } \\
\text { quarter }\end{array}$ & $\begin{array}{c}1 \mathrm{st} \\
\text { quarter }\end{array}$ & $\begin{array}{l}\text { 2nd } \\
\text { quarter }\end{array}$ & $\begin{array}{c}\text { 1st } \\
\text { quarter }\end{array}$ & $\begin{array}{l}\text { 2nd } \\
\text { quarter }\end{array}$ & $\begin{array}{c}1 \text { st } \\
\text { quarter }\end{array}$ & $\begin{array}{l}\text { 2nd } \\
\text { quarter }\end{array}$ & $\begin{array}{c}1 \mathrm{st} \\
\text { quarter }\end{array}$ & $\begin{array}{l}\text { 2nd } \\
\text { quarter }\end{array}$ \\
\hline AVN-1 & $0.33 \mathrm{U}$ & $0.33 \mathrm{U}$ & $0.36 \mathrm{U}$ & $0.36 \mathrm{U}$ & $0.3 \mathrm{U}$ & $0.3 \mathrm{U}$ & $0.37 \mathrm{U}$ & $0.37 \mathrm{U}$ & $0.55 \mathrm{U}$ & $0.55 \mathrm{U}$ \\
\hline AVN-2 & $0.33 \mathrm{U}$ & $0.33 \mathrm{U}$ & $0.36 \mathrm{U}$ & $0.36 \mathrm{U}$ & $0.3 \mathrm{U}$ & $0.3 \mathrm{U}$ & $0.37 \mathrm{U}$ & $0.37 \mathrm{U}$ & $0.55 \mathrm{U}$ & $0.55 \mathrm{U}$ \\
\hline LWDS-MW1 & $0.33 \mathrm{U}$ & $0.33 \mathrm{U}$ & 18.2 & $15.5 \mathrm{~J}$ & 3.63 & 2.61 & $0.37 \mathrm{U}$ & $0.37 \mathrm{U}$ & $0.55 \mathrm{U}$ & $0.55 \mathrm{U}$ \\
\hline $\begin{array}{l}\text { LWDS-MW1 } \\
\text { (Duplicate) }\end{array}$ & $0.33 \mathrm{U}$ & $0.33 \cup$ & 17.0 & $15.1 \mathrm{~J}$ & 3.40 & 2.77 & $0.37 \mathrm{U}$ & $0.37 \mathrm{U}$ & $0.55 \mathrm{U}$ & $0.55 \mathrm{U}$ \\
\hline LWDS-MW2 & $0.33 \mathrm{U}$ & $0.33 \mathrm{U}$ & $0.36 \mathrm{U}$ & $0.36 \mathrm{U}$ & $0.3 \mathrm{U}$ & $0.3 \mathrm{U}$ & $0.37 \mathrm{U}$ & $0.37 \mathrm{U}$ & $0.55 \mathrm{U}$ & $0.55 \mathrm{U}$ \\
\hline TAV-MW1 & $0.33 \mathrm{U}$ & $0.33 \mathrm{U}$ & 2.12 & $2.39 \mathrm{~J}$ & $0.3 \mathrm{U}$ & $0.3 \mathrm{U}$ & $0.37 \mathrm{U}$ & $0.37 \mathrm{U}$ & $0.55 \mathrm{U}$ & $0.55 \mathrm{U}$ \\
\hline TAV-MW2 & $0.33 \mathrm{U}$ & $0.33 \mathrm{U}$ & $0.36 \mathrm{U}$ & $0.36 \mathrm{U}$ & $0.3 \mathrm{U}$ & $0.3 \mathrm{U}$ & $0.37 \mathrm{U}$ & $0.37 \mathrm{U}$ & $0.55 \mathrm{U}$ & $0.55 \mathrm{U}$ \\
\hline TAV-MW3 & $0.33 \mathrm{U}$ & $0.33 \mathrm{U}$ & $0.36 \mathrm{U}$ & $0.36 \mathrm{U}$ & $0.3 \mathrm{U}$ & $0.3 \mathrm{U}$ & $0.37 \mathrm{U}$ & $0.37 \mathrm{U}$ & $0.55 \mathrm{U}$ & $0.55 \mathrm{U}$ \\
\hline TAV-MW4 & $0.33 \mathrm{U}$ & $0.33 \mathrm{U}$ & $0.788 \mathrm{~J}$ & $0.487 \mathrm{~J}$ & $0.3 \mathrm{U}$ & $0.3 \mathrm{U}$ & $0.37 \mathrm{U}$ & $0.37 \mathrm{U}$ & $0.55 \mathrm{U}$ & $0.55 \mathrm{U}$ \\
\hline TAV-MW5 & $0.33 \mathrm{U}$ & $0.33 \mathrm{U}$ & $0.36 \mathrm{U}$ & $0.36 \mathrm{U}$ & $0.3 \mathrm{U}$ & $0.3 \mathrm{U}$ & $0.37 \mathrm{U}$ & $0.37 \mathrm{U}$ & $0.55 \mathrm{U}$ & $0.55 \mathrm{U}$ \\
\hline TAV-MW6 & $0.33 \mathrm{U}$ & $0.33 \mathrm{U}$ & 1.28 & $1.90 \mathrm{~J}$ & $0.3 \mathrm{U}$ & $0.3 \mathrm{U}$ & $0.37 \cup$ & $0.37 \mathrm{U}$ & $0.55 \mathrm{U}$ & $0.55 \mathrm{U}$ \\
\hline TAV-MW7 & $0.911 \mathrm{~J}$ & $0.33 \mathrm{U}$ & $0.36 \mathrm{U}$ & $0.36 \mathrm{U}$ & $0.3 \mathrm{U}$ & $0.3 \mathrm{U}$ & $0.37 \mathrm{U}$ & $0.37 \mathrm{U}$ & $0.55 U$ & $0.55 \mathrm{U}$ \\
\hline $\begin{array}{l}\text { TAV-MW7 } \\
\text { (Duplicate) }\end{array}$ & $0.33 \mathrm{U}$ & $0.33 \mathrm{U}$ & $0.36 \mathrm{U}$ & $0.36 \mathrm{U}$ & $0.3 \mathrm{U}$ & $0.3 \mathrm{U}$ & $0.37 \mathrm{U}$ & $0.37 \mathrm{U}$ & $0.55 \mathrm{U}$ & $0.55 \mathrm{U}$ \\
\hline TAV-MW8 & $0.33 \mathrm{U}$ & $0.33 \mathrm{U}$ & 7.16 & 1.12 & 1.03 & $0.3 \mathrm{U}$ & $0.37 \mathrm{U}$ & $0.37 \mathrm{U}$ & $0.55 \mathrm{U}$ & $0.55 \mathrm{U}$ \\
\hline TAV-MW9 & $0.33 \mathrm{U}$ & $0.33 \mathrm{U}$ & $0.36 \mathrm{U}$ & $0.36 \mathrm{U}$ & $0.3 \mathrm{U}$ & $0.3 \mathrm{U}$ & $0.37 \mathrm{U}$ & $0.37 \mathrm{U}$ & $0.55 \mathrm{U}$ & $0.55 \mathrm{U}$ \\
\hline
\end{tabular}


Table A-2. Nitrate and nitrate plus nitrite data.

\begin{tabular}{|c|c|c|c|c|c|c|}
\hline & \multicolumn{2}{|c|}{$\begin{array}{l}\text { Nitrate Plus Nitrite } \\
\text { (mg/L) }\end{array}$} & \multicolumn{2}{|c|}{$\begin{array}{l}\text { Offsite Lab Nitrate } \\
\text { (mg/L) }\end{array}$} & \multicolumn{2}{|c|}{$\begin{array}{l}\text { Field Lab Nitrate } \\
\qquad(\mathrm{mg} / \mathrm{L})\end{array}$} \\
\hline & 1st quarter & 2nd quarter & 1st quarter & 2nd quarter & 1st quarter & 2nd quarter \\
\hline AVN-1 & 9.10 & 9.15 & $8.0 \mathrm{~A} 2, \mathrm{~J}$ & 8.2 & 7.3 & 7.2 \\
\hline AVN-2 & 9.70 & 9.00 & 7.0 & 8.8 & 8.3 & 7.7 \\
\hline LWDS-MW1 & 12.0 & 14.9 & 12.0 & 12.0 & 9.1 & 9.1 \\
\hline LWDS-MW1 (Duplicate) & 12.1 & 15.0 & 12.0 & 12.0 & No Data & No Data \\
\hline LWDS-MW2 & 7.30 & 8.25 & 6.4 & 6.9 & 5.3 & 6.6 \\
\hline TAV-MW1 & 8.30 & 8.20 & $7.0 \mathrm{HT}, \mathrm{J}, \mathrm{P} 2$ & 6.9 & 6.2 & 4.7 \\
\hline TAV-MW2 & 1.99 & 2.60 & 2.7 & 2.7 & 2.9 & 3.0 \\
\hline TAV-MW3 & 5.35 & 2.72 & 4.3 P2 & 4.9 & 5.7 & 4.1 \\
\hline TAV-MW4 & 7.50 & 7.80 & 6.7 & 6.7 & 6.1 & 5.4 \\
\hline TAV-MW5 & 7.80 & 7.53 & 8.5 & 7.1 & 6.9 & 6.3 \\
\hline TAV-MW6 & 7.05 & 7.50 & $6.5 \mathrm{HT}, \mathrm{J}$ & 6.5 & 6.1 & 6.0 \\
\hline TAV-MW7 & 2.63 & 2.32 & $3.9 \mathrm{HT}, \mathrm{J}$ & 3.9 & 2.9 & 3.6 \\
\hline TAV-MW7 (Duplicate) & 2.67 & 2.32 & $3.9 \mathrm{HT}, \mathrm{J}$ & 3.9 & No Data & No Data \\
\hline TAV-MW8 & 7.00 & 5.55 & 6.3 & 5.3 & 5.0 & 6.7 \\
\hline TAV-MW9 & 2.06 & 2.40 & $5.0 \mathrm{P} 2$ & 3.1 & 3.7 & ND \\
\hline \multicolumn{7}{|c|}{$\begin{array}{l}\mathrm{mg} / \mathrm{L}=\text { milligrams per liter } \\
\text { No Data = Analysis not performed } \\
\text { ND = Not detected } \\
\mathrm{J}=\text { Amount detected is below the practical quantitation limit. The associated value is an estimated quantity. } \\
\text { A2 = Laboratory accuracy and/or bias measurements for the associated matrix spike and/or duplicate do not meet acceptance criteria. } \\
\text { HT = The holding time was exceeded for the associated sample analysis. } \\
\text { P2 = Insufficient quality control data to determine laboratory precision. }\end{array}$} \\
\hline
\end{tabular}


Table A-3. Redox parameters.

\begin{tabular}{|c|c|c|c|c|c|c|c|c|}
\hline & \multicolumn{2}{|c|}{$\begin{array}{l}\text { Ferrous Iron } \\
(\mathrm{mg} / \mathrm{L})\end{array}$} & \multicolumn{2}{|c|}{$\begin{array}{l}\text { Sulfate } \\
(\mathrm{mg} / \mathrm{L})\end{array}$} & \multicolumn{2}{|c|}{$\begin{array}{c}\text { Methane } \\
(\mu \mathrm{g} / \mathrm{L})\end{array}$} & \multicolumn{2}{|c|}{$\begin{array}{c}\text { Manganese II } \\
(\mathrm{mg} / \mathrm{L})\end{array}$} \\
\hline & $\begin{array}{c}\text { 1st } \\
\text { quarter }\end{array}$ & $\begin{array}{l}\text { 2nd } \\
\text { quarter }\end{array}$ & $\begin{array}{c}1 \text { 1st } \\
\text { quarter }\end{array}$ & $\begin{array}{l}\text { 2nd } \\
\text { quarter }\end{array}$ & $\begin{array}{c}1 s t \\
\text { quarter }\end{array}$ & 2nd quarter & $\begin{array}{c}1 \mathrm{st} \\
\text { quarter }\end{array}$ & $\begin{array}{l}\text { 2nd } \\
\text { quarter }\end{array}$ \\
\hline AVN-1 & $0.03 \mathrm{U}$ & $0.03 \mathrm{U}$ & 32.2 & 33.9 & $14 \mathrm{U}$ & $0.57 \mathrm{~B}, \mathrm{~J}, 5.0 \mathrm{U}$ & $0.05 \mathrm{U}$ & $0.05 \mathrm{U}$ \\
\hline AVN-2 & 0.03 & $0.03 \mathrm{U}$ & 30.8 & 29.9 & $14 U$ & $2.3 \mathrm{~B}, \mathrm{~J}$ & $0.05 \mathrm{U}$ & $0.05 \mathrm{U}$ \\
\hline LWDS-MW1 & $0.03 U$ & $0.03 U$ & 45.5 & 38.0 & $14 \mathrm{U}$ & $0.33 \mathrm{~B}, \mathrm{~J}, 5.0 \mathrm{U}$ & $0.05 \mathrm{U}$ & $0.05 \mathrm{U}$ \\
\hline LWDS-MW1 (Duplicate) & $0.03 \mathrm{U}$ & $0.03 U$ & 37.8 & 37.9 & $14 U$ & $0.34 \mathrm{~B}, \mathrm{~J}, 5.0 \mathrm{U}$ & $0.05 \mathrm{U}$ & $0.05 \mathrm{U}$ \\
\hline LWDS-MW2 & $0.03 \mathrm{U}$ & $0.03 \mathrm{U}$ & 40.2 & 38.3 & $14 \mathrm{U}$ & $0.53 \mathrm{~B}, \mathrm{~J}, 5.0 \mathrm{U}$ & $0.05 \mathrm{U}$ & $0.05 \mathrm{U}$ \\
\hline TAV-MW1 & $0.03 \mathrm{U}$ & $0.03 \mathrm{U}$ & 49.5 & 52.6 & $14 U$ & $0.87 \mathrm{~B}, \mathrm{~J}, 5.0 \mathrm{U}$ & $0.05 \mathrm{U}$ & $0.05 \mathrm{U}$ \\
\hline TAV-MW2 & $0.03 \mathrm{U}$ & $0.03 \mathrm{U}$ & 65.6 & 76.6 & $14 \mathrm{U}$ & $0.58 \mathrm{~B}, \mathrm{~J}, 5.0 \mathrm{U}$ & $0.05 \mathrm{U}$ & $0.05 \mathrm{U}$ \\
\hline TAV-MW3 & $0.03 \mathrm{U}$ & $0.03 \mathrm{U}$ & 61.0 & 62.7 & $14 U$ & $0.54 \mathrm{~B}, \mathrm{~J}, 5.0 \mathrm{U}$ & $0.05 U$ & $0.05 \mathrm{U}$ \\
\hline TAV-MW4 & $0.03 \mathrm{U}$ & $0.03 U$ & 34.4 & 39.4 & $14 U$ & $0.70 \mathrm{~B}, \mathrm{~J}, 5.0 \mathrm{U}$ & $0.05 \mathrm{U}$ & $0.05 \mathrm{U}$ \\
\hline TAV-MW5 & $0.03 U$ & $0.03 \mathrm{U}$ & 41.5 & 40.3 & $14 U$ & $0.51 \mathrm{~B}, \mathrm{~J}, 5.0 \mathrm{U}$ & $0.05 \mathrm{U}$ & $0.05 \mathrm{U}$ \\
\hline TAV-MW6 & $0.03 \mathrm{U}$ & $0.03 \mathrm{U}$ & 45.3 & 50.9 & $14 \mathrm{U}$ & $0.33 \mathrm{~B}, \mathrm{~J}, 5.0 \mathrm{U}$ & $0.05 \mathrm{U}$ & $0.05 \mathrm{U}$ \\
\hline TAV-MW7 & $0.03 U$ & 0.06 & 58.2 & 60.4 & $14 U$ & $0.31 \mathrm{~B}, \mathrm{~J}, 5.0 \mathrm{U}$ & $0.05 U$ & $0.05 \mathrm{U}$ \\
\hline TAV-MW7 (Duplicate) & $0.03 U$ & No Data & 62.2 & 60.9 & $14 U$ & $0.30 \mathrm{~B}, \mathrm{~J}, 5.0 \mathrm{U}$ & $0.05 \mathrm{U}$ & $0.05 \mathrm{U}$ \\
\hline TAV-MW8 & $0.03 \mathrm{U}$ & $0.03 U$ & 43.1 & 50.0 & $14 U$ & $\begin{array}{c}0.22 \mathrm{~B}, \mathrm{~J}, \mathrm{COL} \\
5.0 \mathrm{U}\end{array}$ & $0.05 U$ & $0.05 \mathrm{U}$ \\
\hline TAV-MW9 & $0.03 \mathrm{U}$ & 0.06 & 50.8 & 49.7 & $14 U$ & $0.33 \mathrm{~B}, \mathrm{~J}, 5.0 \mathrm{U}$ & $0.05 \mathrm{U}$ & $0.05 \mathrm{U}$ \\
\hline \multicolumn{9}{|c|}{ 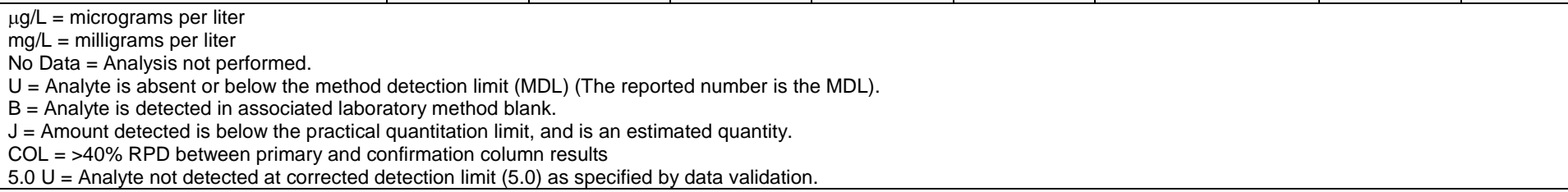 } \\
\hline
\end{tabular}


Table A-4. Dechlorination products (ethene, ethane, and chloride) and surrogate measure for bioavailable electron donor (DOC and COD).

\begin{tabular}{|c|c|c|c|c|c|c|c|c|c|c|}
\hline & \multicolumn{2}{|c|}{$\begin{array}{c}\text { Ethene } \\
(\mu \mathrm{g} / \mathrm{L})\end{array}$} & \multicolumn{2}{|c|}{$\begin{array}{c}\text { Ethane } \\
(\mu \mathrm{g} / \mathrm{L})\end{array}$} & \multicolumn{2}{|c|}{$\begin{array}{c}\text { Chloride } \\
\text { (mg/L) }\end{array}$} & \multicolumn{2}{|c|}{$\begin{array}{l}\text { DOC (filtered) } \\
\text { (mg/L) }\end{array}$} & \multicolumn{2}{|c|}{$\begin{array}{l}\text { COD } \\
(\mathrm{mg} / \mathrm{L})\end{array}$} \\
\hline & $\begin{array}{c}1 \text { st } \\
\text { quarter }\end{array}$ & $\begin{array}{l}\text { 2nd } \\
\text { quarter }\end{array}$ & $\begin{array}{c}1 \text { st } \\
\text { quarter }\end{array}$ & $\begin{array}{l}\text { 2nd } \\
\text { quarter }\end{array}$ & $\begin{array}{c}1 s t \\
\text { quarter }\end{array}$ & $\begin{array}{c}\text { 2nd } \\
\text { quarter }\end{array}$ & $\begin{array}{c}1 \text { st } \\
\text { quarter }\end{array}$ & $\begin{array}{c}\text { 2nd } \\
\text { quarter }\end{array}$ & $\begin{array}{c}\text { 1st } \\
\text { quarter }\end{array}$ & $\begin{array}{c}\text { 2nd } \\
\text { quarter }\end{array}$ \\
\hline AVN-1 & $4.36 \mathrm{U}$ & $0.40 \mathrm{U}$ & $4.77 \mathrm{U}$ & $0.39 \mathrm{U}$ & 9.19 & 9.27 & 1.38 & 0.722 & 29.2 & $\begin{array}{c}0.890 \mathrm{U}, \mathrm{B} 3, \\
\mathrm{R}\end{array}$ \\
\hline AVN-2 & $4.36 \mathrm{U}$ & $0.40 \mathrm{U}$ & $4.77 \mathrm{U}$ & $0.39 \mathrm{U}$ & 10.5 & 10.2 & 0.540 & 0.269 & 29.2 & $1.46 \mathrm{~J}, \mathrm{~B} 3$ \\
\hline LWDS-MW1 & $4.36 \mathrm{U}$ & $0.40 \mathrm{U}$ & $4.77 \mathrm{U}$ & $0.39 \mathrm{U}$ & 83.6 & $75.5 \mathrm{~B}$ & 0.595 B & $0.586 \mathrm{~B}, \mathrm{~B} 3, \mathrm{~J}$ & 20.9 B, B3, J & 11.5 \\
\hline $\begin{array}{l}\text { LWDS-MW1 } \\
\text { (Duplicate) }\end{array}$ & $4.36 \mathrm{U}$ & $0.40 \mathrm{U}$ & $4.77 \mathrm{U}$ & $0.39 \mathrm{U}$ & 69.9 & $75.4 \mathrm{~B}$ & $0.675 \mathrm{~B}$ & $0.592 \mathrm{~B}, \mathrm{~B} 3, \mathrm{~J}$ & $24.9 \mathrm{~B}, \mathrm{~B} 3, \mathrm{~J}$ & 10.4 \\
\hline LWDS-MW2 & $4.36 \mathrm{U}$ & $0.40 \mathrm{U}$ & $4.77 \mathrm{U}$ & $0.39 \mathrm{U}$ & 19.8 & 18.6 & 1.03 & 0.272 & 19.6 B, B3, J & $1.46 \mathrm{~J}, \mathrm{~B} 3$ \\
\hline TAV-MW1 & $4.36 \mathrm{U}$ & $0.40 \mathrm{U}$ & $4.77 \mathrm{U}$ & $0.39 \mathrm{U}$ & 44.2 & 48.0 & $1.27 \mathrm{~B}$ & $0.731 \mathrm{~B}$ & $4.88 \mathrm{U}$ & 7.39 \\
\hline TAV-MW2 & $4.36 \mathrm{U}$ & $0.40 \mathrm{U}$ & $4.77 \mathrm{U}$ & $0.39 \mathrm{U}$ & 71.4 & 94.1 & $0.624 \mathrm{~B}$ & 0.446 & $15.1 \mathrm{~B}, \mathrm{~B} 3, \mathrm{~J}$ & 6.02 \\
\hline TAV-MW3 & $4.36 \mathrm{U}$ & $0.40 \mathrm{U}$ & $4.77 \mathrm{U}$ & $0.39 \mathrm{U}$ & 26.9 & 25.7 & $0.550 \mathrm{~B}$ & 0.495 & $4.88 \mathrm{U}$ & $4.72 \mathrm{~J}$ \\
\hline TAV-MW4 & $4.36 \mathrm{U}$ & $0.40 \mathrm{U}$ & $4.77 \mathrm{U}$ & $0.39 \mathrm{U}$ & 29.7 & 25.9 & 1.16 & 0.55 & 16.6 B, B3,J & $0.890 \mathrm{U}$ \\
\hline TAV-MW5 & $4.36 \mathrm{U}$ & $0.40 \mathrm{U}$ & $4.77 \mathrm{U}$ & $0.39 \mathrm{U}$ & 17.3 & 17.6 & 1.08 & 0.206 & 29.2 & $1.46 \mathrm{~J}$ \\
\hline TAV-MW6 & $4.36 \mathrm{U}$ & $0.40 \mathrm{U}$ & $4.77 \mathrm{U}$ & $0.39 \mathrm{U}$ & 31.5 & $37.3 \mathrm{~B}$ & $0.801 \mathrm{~B}$ & $0.403 \mathrm{~B}, \mathrm{~B} 3, \mathrm{~J}$ & $4.88 \mathrm{U}$ & $10.4 \mathrm{~A} 2, \mathrm{~J}$ \\
\hline TAV-MW7 & $4.36 \mathrm{U}$ & $0.40 \mathrm{U}$ & $4.77 \mathrm{U}$ & $0.39 \mathrm{U}$ & 24.7 & $26.3 \mathrm{~B}$ & $0.452 \mathrm{~B}$ & $0.394 \mathrm{~B}, \mathrm{~B} 3, \mathrm{~J}$ & $4.88 \mathrm{U}$ & $11.1 \mathrm{~A} 2, \mathrm{~J}$ \\
\hline $\begin{array}{l}\text { TAV-MW7 } \\
\text { (Duplicate) }\end{array}$ & $4.36 \mathrm{U}$ & $0.40 \mathrm{U}$ & $4.77 \mathrm{U}$ & $0.39 \mathrm{U}$ & 26.8 & $26.6 \mathrm{~B}$ & $0.561 \mathrm{~B}$ & 0.504 B, B3, J & $4.88 \mathrm{U}$ & 10.8 A2, J \\
\hline TAV-MW8 & $4.36 \mathrm{U}$ & $0.40 \mathrm{U}$ & $4.77 \mathrm{U}$ & $0.39 \mathrm{U}$ & 51.2 & 32.8 & 1.24 & 0.610 & $15.0 \mathrm{~B}, \mathrm{~B} 3, \mathrm{~J}$ & $4.72 \mathrm{~B} 3, \mathrm{~J}$ \\
\hline TAV-MW9 & $4.36 \mathrm{U}$ & $0.40 \mathrm{U}$ & $4.77 \mathrm{U}$ & $0.39 \mathrm{U}$ & 31.6 & $26.5 \mathrm{~B}$ & $1.41 \mathrm{~B}$ & $1.89 \mathrm{~B}$ & $4.88 \mathrm{U}$ & 16.8 \\
\hline \multicolumn{11}{|c|}{$\begin{array}{l}\mu \mathrm{g} / \mathrm{L}=\text { micrograms per liter } \\
\mathrm{mg} / \mathrm{L}=\text { milligrams per liter } \\
\mathrm{U}=\text { Analyte is absent or below the method detection limit }(\mathrm{MDL}) \text { (The reported number is the MDL). } \\
\mathrm{B}=\text { Analyte is detected in associated laboratory method blank. } \\
\mathrm{B} 3=\text { Analyte present in associated continuing calibration blank } \\
\mathrm{J}=\text { Amount detected is below the practical quantitation limit, and is an estimated quantity. } \\
\mathrm{R}=\text { The data are unusable for their intended purpose. } \\
\mathrm{A} 2=\text { Laboratory accuracy and/or bias measurements for the associated matrix spike and/or duplicate do not meet acceptance criteria. } \\
\mathrm{DOC}=\text { dissolved organic carbon } \\
\text { COD = chemical oxygen demand }\end{array}$} \\
\hline
\end{tabular}


Table A-5. Microbial nutrients (orthophosphate and ammonia) and indicators of microbial respiration (carbon dioxide and alkalinity).

\begin{tabular}{|c|c|c|c|c|c|c|c|c|}
\hline & \multicolumn{2}{|c|}{$\begin{array}{l}\text { Orthophosphate as } \\
\text { Phosphorous (mg/L) }\end{array}$} & \multicolumn{2}{|c|}{$\begin{array}{l}\text { Ammonia as Nitrogen } \\
(\mathrm{mg} / \mathrm{L})\end{array}$} & \multicolumn{2}{|c|}{$\begin{array}{l}\text { Carbon Dioxide } \\
\text { (mg/L) }\end{array}$} & \multicolumn{2}{|c|}{$\begin{array}{l}\text { Alkalinity } \\
\text { (mg/L) }\end{array}$} \\
\hline & 1st quarter & 2nd quarter & 1st quarter & 2nd quarter & 1st quarter & 2nd quarter & 1st quarter & 2nd quarter \\
\hline AVN-1 & $0.5 \mathrm{U}, \mathrm{P} 2$ & $0.13 \mathrm{U}$ & $0.024 \mathrm{U}$ & $0.0159 \mathrm{U}$ & 250 & 240 & 153 & 125 \\
\hline AVN-2 & $0.5 \mathrm{U}, \mathrm{P} 2$ & $0.13 U$ & $0.040 \mathrm{~J}$ & $\begin{array}{c}0.0159 \mathrm{~B} \\
\text { B3,UJ }\end{array}$ & 250 & 200 & 150 & 155 \\
\hline LWDS-MW1 & $0.5 \mathrm{U}$ & $0.13 U$ & $0.024 \mathrm{U}$ & 0.0159 UJ, B3 & 420 & 230 & 186 & 193 \\
\hline $\begin{array}{l}\text { LWDS-MW1 } \\
\text { (Duplicate) }\end{array}$ & $0.5 \mathrm{U}$ & $0.13 \mathrm{U}$ & $0.024 \mathrm{U}$ & $0.0159 \mathrm{UJ}, \mathrm{B} 3$ & No Data & No Data & No Data & No Data \\
\hline LWDS-MW2 & $0.5 \mathrm{U}, \mathrm{P} 2$ & $0.13 \mathrm{U}$ & $0.024 \mathrm{U}$ & $0.0159 \mathrm{UJ}, \mathrm{B} 3$ & 330 & 250 & 175 & 165 \\
\hline TAV-MW1 & $0.5 \mathrm{U}, \mathrm{UJ}, \mathrm{HT}$ & $0.13 U$ & $0.024 \mathrm{U}$ & 0.0159 UJ, B3 & 340 & 250 & 124 & 174 \\
\hline TAV-MW2 & $0.5 \mathrm{U}$ & $0.13 \mathrm{U}$ & $0.024 \mathrm{U}$ & 0.0159 UJ, B3 & 325 & 360 & 216 & 207 \\
\hline TAV-MW3 & $0.5 \mathrm{U}$ & $0.13 U$ & $0.024 \mathrm{U}$ & $\begin{array}{c}0.0159 \text { B, UJ, } \\
\text { B3 }\end{array}$ & 300 & 230 & 177 & 174 \\
\hline TAV-MW4 & $0.5 \mathrm{U}, \mathrm{P} 2$ & $0.13 \mathrm{U}$ & $0.024 \mathrm{U}$ & $0.0159 \mathrm{U}$ & 370 & 200 & 168 & 148 \\
\hline TAV-MW5 & $0.5 \mathrm{U}, \mathrm{P} 2$ & $0.13 \mathrm{U}$ & $0.024 \mathrm{U}$ & $0.0159 \mathrm{UJ}, \mathrm{B} 3$ & 290 & 250 & 171 & 175 \\
\hline TAV-MW6 & $0.5 \mathrm{U}, \mathrm{UJ}, \mathrm{HT}$ & $0.13 \mathrm{U}$ & $0.024 \mathrm{U}$ & $0.0159 \mathrm{UJ}, \mathrm{B} 3$ & 320 & 250 & 202 & 171 \\
\hline TAV-MW7 & $0.5 \mathrm{U}, \mathrm{UJ}, \mathrm{HT}$ & $0.13 \mathrm{U}$ & $0.024 \mathrm{U}$ & $0.0159 \mathrm{UJ}, \mathrm{B} 3$ & 250 & 225 & 221 & 205 \\
\hline $\begin{array}{l}\text { TAV-MW7 } \\
\text { (Duplicate) }\end{array}$ & $0.5 \mathrm{U}, \mathrm{UJ}, \mathrm{HT}$ & $0.13 U$ & $0.024 \mathrm{U}$ & $0.0159 \mathrm{UJ}, \mathrm{B} 3$ & No Data & No Data & No Data & No Data \\
\hline TAV-MW8 & $0.5 \mathrm{U}, \mathrm{P} 2$ & $0.13 \mathrm{U}$ & $0.024 \mathrm{U}$ & $0.0159 \mathrm{UJ}, \mathrm{B} 3$ & 440 & 330 & 183 & 161 \\
\hline TAV-MW9 & $0.5 \mathrm{U}$ & $0.13 \mathrm{U}$ & $0.024 \mathrm{U}$ & 0.0159 UJ, B3 & 480 & 380 & 163 & 172 \\
\hline \multicolumn{9}{|c|}{$\begin{array}{l}\text { mg/L = milligrams per liter } \\
\text { No Data = Analysis not performed. } \\
\text { B = Analyte is detected in associated laboratory method blank. } \\
\text { B3 = Analyte present in associated continuing calibration blank. } \\
\text { = Analyte is absent or below the method detection limit (MDL) (The reported number is the MDL). } \\
\text { UJ = Analyte not detected above laboratory method detection limit, but associated value is an estimate and may be inaccurate or imprecise. } \\
2=\text { Insufficient quality control data to determine laboratory precision. } \\
\mathrm{HT}=\text { The holding time was exceeded for the associated sample analysis. }\end{array}$} \\
\hline
\end{tabular}


Table A-6. Water quality measurements.

\begin{tabular}{|c|c|c|c|c|c|c|c|c|}
\hline & \multicolumn{2}{|c|}{$\begin{array}{l}\text { Dissolved Oxygen } \\
\quad(\mathrm{mg} / \mathrm{L})\end{array}$} & \multicolumn{2}{|c|}{$\begin{array}{l}\text { ORP } \\
(\mathrm{mV})\end{array}$} & \multicolumn{2}{|c|}{$\mathrm{pH}$} & \multicolumn{2}{|c|}{$\begin{array}{c}\text { Temperature } \\
\left({ }^{\circ} \mathrm{C}\right)\end{array}$} \\
\hline & 1st quarter & 2nd quarter & 1st quarter & 2nd quarter & 1st quarter & 2nd quarter & 1st quarter & 2nd quarter \\
\hline AVN-1 & 4.36 & 5.04 & 242.7 & 100.2 & 7.77 & 7.71 & 16.41 & 20.40 \\
\hline AVN-2 & 3.30 & 5.27 & 234.4 & 197.3 & 8.39 & 7.75 & 14.78 & 19.69 \\
\hline LWDS-MW1 & 6.86 & 6.42 & 188.1 & 163.0 & 7.55 & 7.51 & 16.90 & 16.33 \\
\hline LWDS-MW2 & 5.23 & 4.80 & 244.3 & 97.5 & 7.66 & 7.63 & 16.01 & 18.34 \\
\hline TAV-MW1 & 8.19 & 4.97 & 185.0 & 159.7 & 7.84 & 7.40 & 16.03 & 20.52 \\
\hline TAV-MW2 & 6.03 & 5.03 & 220.8 & 136.9 & 7.42 & 7.39 & 17.18 & 19.49 \\
\hline TAV-MW3 & 8.04 & 7.51 & 210.4 & 242.5 & 7.72 & 7.58 & 16.18 & 21.10 \\
\hline TAV-MW4 & 7.10 & 7.44 & 274.1 & 202.8 & 7.70 & 7.62 & 16.68 & 20.90 \\
\hline TAV-MW5 & 3.84 & 4.82 & 267.8 & 191.8 & 7.68 & 7.57 & 15.73 & 17.19 \\
\hline TAV-MW6 & 6.38 & $\begin{array}{c}\text { Not } \\
\text { Measured }\end{array}$ & 200.7 & 171.4 & 7.58 & 7.43 & 17.67 & 20.46 \\
\hline TAV-MW7 & 2.04 & 0.46 & 177.0 & 52.4 & 7.54 & 7.18 & 16.11 & 20.43 \\
\hline TAV-MW8 & 7.12 & 6.79 & 265.5 & 208.6 & 7.59 & 7.61 & 16.84 & 20.27 \\
\hline TAV-MW9 & 4.49 & 1.37 & 97.5 & 69.3 & 7.60 & 7.41 & 15.78 & 18.59 \\
\hline
\end{tabular}


This Page Intentionally Left Blank 
Attachment E

Evaluation of an Intrinsic Aerobic Degradation Mechanism

E-1 
This Page Intentionally Left Blank

E-2 


\title{
Evaluation of an Intrinsic Aerobic Degradation Mechanism, Technical Area-V Groundwater at Sandia National Laboratories/New Mexico
}

\author{
April 2005
}

Prepared by

Sandia National Laboratories

Albuquerque, New Mexico 87185 and Livermore, California 94550

Sandia is a multiprogram laboratory operated by Sandia Corporation,

a Lockheed Martin Company, for the United States Department of Energy's

National Nuclear Security Administration under Contract DE-AC04-94AL85000.

Approved for public release; further dissemination unlimited.

17. Sandia National Laboratories 


\begin{abstract}
The objective of this document is to describe the field scale studies and the data analysis and interpretation for the sampling activities at Sandia National Laboratories/New Mexico (SNL/NM) Technical Area V (TA-V). The contaminants of concern at SNL/NM TA-V include nitrate and two volatile organic compounds, trichloroethene (TCE) and tetrachloroethene (PCE). This report documents the application of enzyme activity-dependent probes and DNA studies to evaluate the potential for cometabolic activity to degrade TCE at TA-V. Positive results from the application of probes to both contaminated and uncontaminated groundwater provided direct evidence of cometabolic enzymatic activity in all of the wells sampled at TA-V. This study coupled enzymatic probes (evidence of activity) with DNA analysis (evidence of the degradative gene and potential for activity) to establish defensible, direct evidence that intrinsic aerobic TCE cometabolism by indigenous microbial populations is an existing mechanism for natural attenuation at TA-V.
\end{abstract}




\section{CONTENTS}

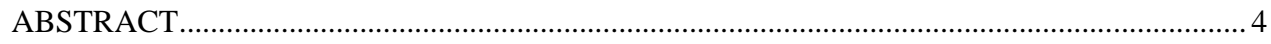

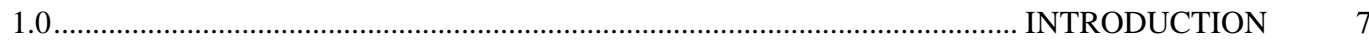

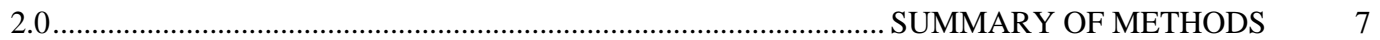

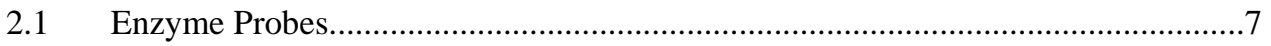

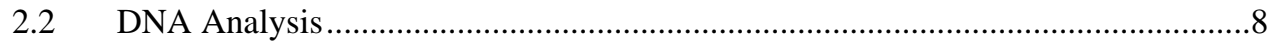

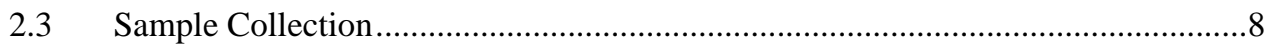

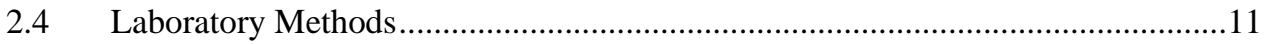

2.4.1 Enzyme Activity Determination 11

2.4.2 DNA analysis (PCR) 12

2.4.3 DAPI Staining 12

3.0 RESULTS

3.1 Enzyme Probe Sample Results

3.2 DNA Studies

4.0 .

..SUMMARY AND CONCLUSIONS

5.0 REFERENCES

Appendix A. Enzyme Probe Data.

\section{FIGURES}

1. TCE Concentration in TA-V Groundwater. ............................................................... 9

2. Micrographs of TAV-MW5 (Sample ID 066467-042)................................................. 15

3. Amplification of toluene genes using the PHE primers. ................................................... 16

4. Amplification of toluene genes using the RMO primers................................................. 16

5. Amplification of toluene genes using the TOD primers............................................. 16

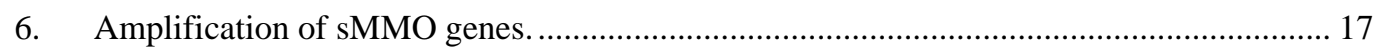

\section{TABLES}

1. Results of enzyme probe analysis................................................................... 13

2. Outcome of combining enzyme probe and DNA analysis results................................... 15

3. Results of amplification of DNA in groundwater from wells at Sandia TA-V................. 17

E-5 


\section{ACRONYMS}

$\begin{array}{ll}\text { 3-HPA } & \text { 3-hydroxyphenylacetylene } \\ \text { AR/COC } & \text { analysis request/chain-of-custody } \\ \text { bp } & \text { base pair } \\ \text { CME } & \text { Corrective Measures Evaluation } \\ \text { COC } & \text { contaminant of concern } \\ \text { COOC } & \text { Compliance Order of Consent } \\ \text { DAPI } & \text { 4,6-diamindino-phenylindole } \\ \text { DCE } & \text { dichloroethene } \\ \text { DNA } & \text { deoxyribonucleic acid } \\ \text { LWDS } & \text { Liquid Waste Disposal System } \\ \text { MNA } & \text { monitored natural attenuation } \\ \text { NMED } & \text { New Mexico Environment Department } \\ \text { PA } & \text { phenylacetylene } \\ \text { PCE } & \text { tetrachloroethene } \\ \text { PCR } & \text { polymerase chain reaction } \\ \text { PHE } & \text { phenol monooxygenase } \\ \text { RMO } & \text { toluene monooxygenase } \\ \text { sMMO } & \text { soluble methane monooxygenase } \\ \text { SNL/NM } & \text { Sandia National Laboratories/New Mexico } \\ \text { TA-V } & \text { tochnical Area-V } \\ \text { TCE } & \text { volatile organic compounds } \\ \text { TOD } & \text { UV }\end{array}$




\subsection{INTRODUCTION}

The Corrective Measures Evaluation (CME) Work Plan Technical Area-V Groundwater (SNL/NM, 2004a) was prepared as directed by the Compliance Order on Consent (COOC) issued by the New Mexico Environment Department (NMED) (NMED, 2004). The Work Plan outlined a process for evaluating remedial alternatives in order to identify a corrective measure for the contaminants of concern (COCs) in Sandia National Laboratories/New Mexico Technical Area-V (TA-V) groundwater. The COCs at TA-V include volatile organic compounds (VOCs) trichloroethene (TCE) and tetrachloroethene (PCE), as well as nitrate. The CME Work Plan identified a four-stage data collection and interpretation process, as follows:

1. Paper study,

2. Mathematical modeling,

3. Laboratory studies, and

4. Field scale studies.

In order to determine the effectiveness of implementation of monitored natural attenuation (MNA) at TA-V, the field-scale studies stage includes investigating natural attenuation mechanisms in TA-V groundwater. One such mechanism is aerobic cometabolic oxidation, a process by which a microbial cell metabolizes a substrate (in this case, TCE) in the presence of a second substrate which is used as the primary source of carbon and energy. This paper presents results and interpretations of enzyme probe analyses applied to TA-V groundwater samples.

\subsection{SUMMARY OF METHODS}

This section presents a summary of the techniques used for the analysis of groundwater samples. Enzyme probes are research tools that have the potential to provide direct evidence for aerobic cometabolic oxidation of VOCs, most notably TCE. DNA analysis serves as supportive evidence for the enzyme probe analysis and findings.

\subsection{Enzyme Probes}

Studies have shown that subsurface microbial communities are metabolically active and produce enzymes that catalyze diverse biochemical reactions, including cometabolism of a wide variety of chlorinated hydrocarbons (Wilson and Wilson, 1985; Fogel et al., 1986; Little et al., 1988; Oldenhuis et al., 1989, 1991; Tsien et al., 1989; Alvarez-Cohen and McCarty, 1991; Speitel and Alley, 1991; Brockman, 1995; Pfiffner et al., 1997). In contrast to anaerobic microbial populations that reductively dechlorinate TCE, many aerobic microorganisms cometabolically degrade TCE via oxygenase-catalyzed reactions, including organisms that use methane, propane, benzene, phenol, toluene, and ammonia as natural growth substrates (Ensley, 1991). Thus, aerobic cometabolism requires the presence of a primary substrate and oxygen but can fortuitously transform a cometabolic substrate if both requirements are met. If the primary substrate is absent, the enzyme required for cometabolic transformation will not be induced and the cometabolic transformation will not occur. TCE, cis-DCE (dichloroethene), trans-DCE, and vinyl chloride have all been shown to be susceptible to cometabolic oxidation under aerobic conditions (Wilson and Wilson, 1985; Semprini et al., 1990). For more details of cometabolic enzyme and pathways, refer to Final Quick Win Profile Sampling Effort (Wymore et al., 2004). 
Activity-dependent enzyme probes are research tools that provide direct evidence that the mechanism for aerobic cometabolic oxidation of chlorinated ethenes, most notably TCE, is present and active in the aquifer. Enzyme activity probes that serve as alternate substrates for TCE cometabolizing enzymes have been developed for four separate toluene oxygenases (Keener et al., 1997; Keener et al., 1998; Kauffman et al., 2003; Clingenpeel et al., 2005a), and for the soluble methane monooxygenase (sMMO; Miller et al., 2002). These non-fluorescent probes are transformed by either the toluene or methane oxygenase enzymes into a strongly fluorescent product upon transformation. A clear, quantifiable signal (i.e., fluorescent probe product) is detected only when the enzyme of interest is actively functioning. If the appropriate enzyme is not present, or it is present but not active in a given sample, then the probes will not be transformed and no fluorescence will be detected. This class of probes provides direct evidence of specific cometabolic enzyme activity toward chlorinated solvents at remediation sites; this evidence is essential for documenting that intrinsic bioremediation is occurring in a given environment (Madsen, 1991; Madsen, 1998).

The nomenclature "toluene oxygenase" is derived from early laboratory studies and the presence of these enzymes is not an indication that toluene is present in the groundwater. The toluene enzymes may under ambient conditions be induced by the presence of any number of aromatic substances. Genes coding for toluene oxygenases have highly conserved overlap regions with genes for other aromatic oxygenases, including phenol and benzene (Fries et al., 1997; Mesarch et al., 2000; Parales et al., 2000; Baldwin et al., 2003). While the activity detected with the enzyme probe is derived from toluene induced pathways (fluorescent products are specific to degradation by the toluene induced enzymes), laboratory studies have suggested that these enzymes are not limited to degradation of or induction by toluene (Wackett, 1984; Parales et al., 2000).

\subsection{DNA Analysis}

In addition to the enzyme probes, a series of DNA probes have been developed or adapted to investigate the genetic potential of toluene and methane-oxidizing microbial populations (McDonald et al., 1995; Baldwin et al., 2003). While enzyme probes measure actual activity and provide data that are otherwise not obtainable, DNA techniques should be used to provide context for the activity probes by detecting functional gene presence. These techniques are designed to look for the presence of the genes coding for toluene or methane (sMMO) oxygenases. If these analyses find that the gene is present, then the sample is considered to have the potential for degradative activity, which is not related to what the organisms are actually doing (i.e. activity). This is considered indirect or supporting evidence for the enzyme activity measurements. However, if the sample has an enzyme activity probe response, then there is direct evidence of degradative activity.

\subsection{Sample Collection}

Samples were collected from all $13 \mathrm{TA}-\mathrm{V}$ groundwater monitoring wells (Figure 1) in conjunction with the current voluntary monitoring program for TA-V by SNL/NM sampling crews. Samples were shipped to Northern Arizona University for analysis. 


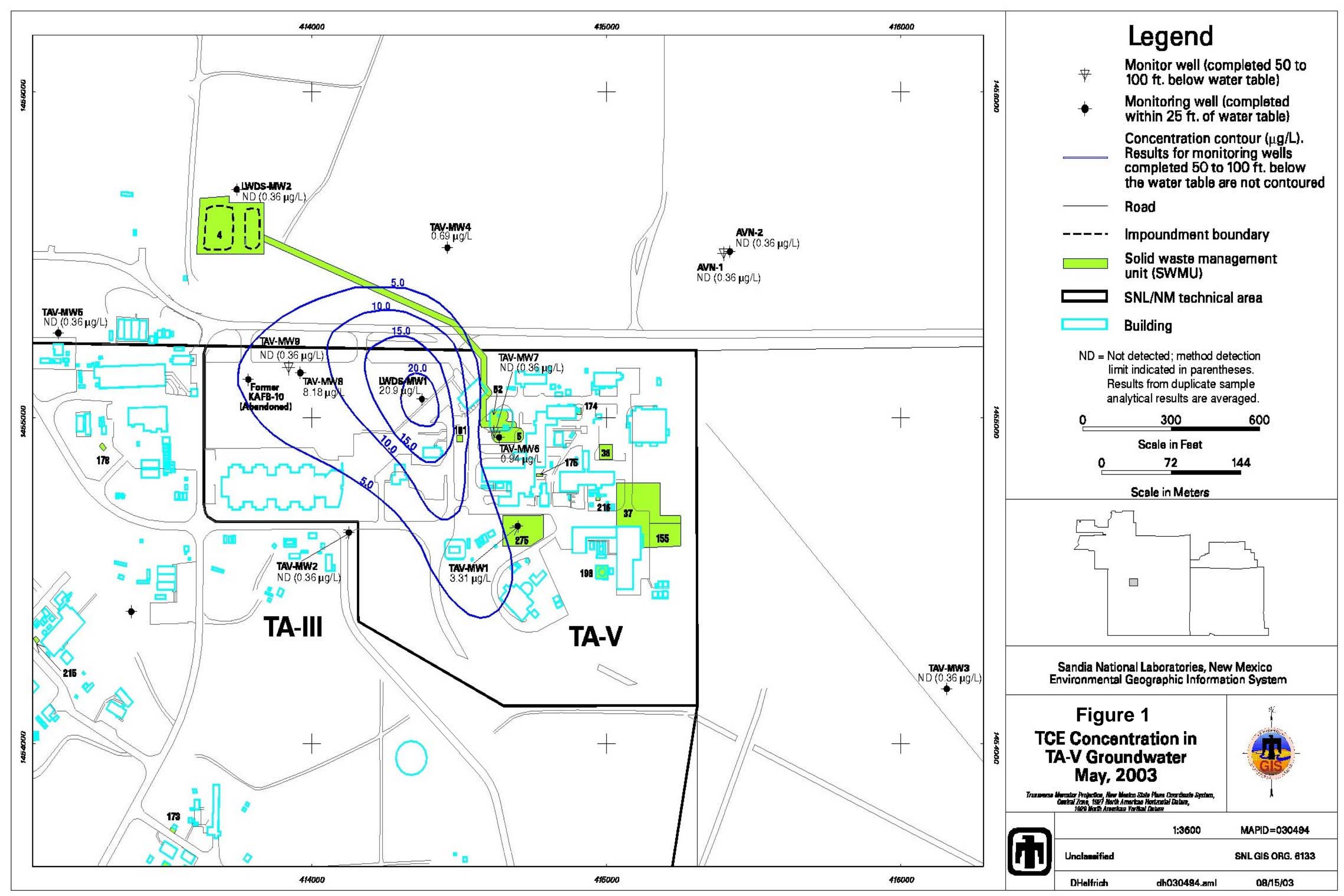

Figure 1. TCE Concentration in TA-V Groundwater 
This Page Intentionally Left Blank 


\subsection{Laboratory Methods}

This section describes the analytical techniques used, including enzyme probe analysis, total cell count (DAPI), and deoxyribonucleic acid (DNA) analysis. DAPI (4,6-diamindino-phenylindole) staining provides a total microbial cell count for a given sample. This number provides a relative means of quantifying the number of cells that have active enzymes, as determined by enzyme probe analysis. Enzyme probes provide a direct measure of the activity of both the sMMO and toluene oxygenases. Polymerase chain reaction (PCR) provides proof of the presence the gene of interest (sMMO or toluene oxygenase) by amplifying these regions of microbial DNA.

The following techniques are widely accepted for use in laboratory studies (Keener et al., 1998; 2001; Miller et al., 2002; Kauffman et al., 2003; Clingenpeel et al., 2005a) but have been modified herein for assessment of a contaminated field site (Wymore et al., 2004; Howard et al., 2005). The sequence for analysis is as follows:

1. Enzyme activity probe analysis,

2. DNA analysis, and

3. DAPI staining.

\subsubsection{Enzyme Activity Determination}

Enzyme activity was determined using two methods, toluene probes and the sMMO probe, for all $13 \mathrm{TA}-\mathrm{V}$ groundwater monitoring locations. Evaluation with the toluene probes is performed by filtering $10 \mathrm{~mL}$ of groundwater onto black, polycarbonate filters on a vacuum manifold. One $\mathrm{mL}$ of an enzyme activity probe ( $5 \mathrm{mM}$ phenylacetylene (PA), $5 \mathrm{mM}$ trans-cinnamonitrile, and 5 $\mathrm{mM}$ 3-hydroxyphenylacetylene (3-HPA)) was pipetted onto the surface of the filter and incubated at room temperature for 10 minutes. PA and 3-HPA label cells with varying affinities that express the following toluene enzymes: 2,3 dioxygenase, toluene 2-monooxygenase and toluene 3-monooxygenase (Keener et al., 1998; Kauffman et al., 2003), while transcinnamonitrile only labels cells with active toluene-2,3 dioxygenase enzymes. A separate filter was used for each of the three probes. After 10 minutes, vacuum was reapplied to remove the solution and the filter was washed with buffer to remove any residual substrate that could potentially interfere with seeing a fluorescent signal. The filter was mounted on a glass microscope slide and examined for fluorescent cells by epifluorescent microscopy. If any of the toluene enzymes are active, a clear fluorescent signal will be seen when looking at the filter under the microscope; however, if no enzyme is active, the filter will appear black and no cells will be fluorescent.

Evaluation with the sMMO probe is similar to the toluene probes with the following modifications. Water samples are filtered onto Supor filters to prevent background interference from polycarbonate filters. In addition, the product of coumarin transformation by the sMMO enzyme is highly soluble (7-hydroxycoumarin, Miller et al., 2002); therefore, the fluorescence is measured fluorometrically (i.e., in solution). 


\subsubsection{DNA analysis (PCR)}

DNA was extracted from all $13 \mathrm{TA}-\mathrm{V}$ groundwater monitoring well locations. Polymerase chain reaction (PCR) amplification of gene-specific regions of DNA was used to determine if the genes that encode for the soluble methane or toluene enzymes were present. The sMMO gene was amplified with primers which target the mmoX component of the sMMO oxygenase (McDonald et al., 1995). Amplification of the toluene enzyme genes was achieved by using degenerate primers that do not amplify a specific enzyme but multiple toluene enzyme genes (Baldwin et al., 2003). Therefore, many PCR amplifications with multiple primer sets are required to cover all of the possible toluene enzyme pathways. Three primer sets were used: phenol monooxygenase (PHE), toluene monooxygenase (RMO), and toluene dioxygenase (TOD). For example, the PHE primers amplify the toluene enzyme gene fragment (206 base pair [bp]) of the 2-monooxygenase, 3-monoxygenase, and 4-monoxygenase, the RMO primers amplify a fragment (466 bp) specific to the toluene-3 and 4-monooxygenase genes, and the TOD series amplify an approximate $757 \mathrm{bp}$ fragment from toluene-2,3-dioxygenase genes.

PCR amplified DNA was visualized by gel electrophoresis; the gels were stained with $0.5 \mu \mathrm{g} / \mathrm{ml}$ ethidium. After running the samples on a gel and staining with ethidium, fragments of DNA were stained and easily visualized when viewed with ultraviolet (UV) light. Photographs of gels are taken to determine the density of the bands (concentration) as well as for comparison to DNA ladders to determine the size of the fragment. Ladders produce "stained" bands at $100 \mathrm{bp}$ intervals and serve as a standard for running accurate gels.

\subsubsection{DAPI Staining}

DAPI is a general fluorescent stain that binds to the DNA of bacterial cells. The total number of cells is determined by the number of cells that can be stained and counted using epifluorescent microscopy. Groundwater samples $(10 \mathrm{~mL})$ were filtered onto black polycarbonate filters. DAPI was added onto the surface of the filter and incubated for 5 minutes $(60 \mu \mathrm{l} / \mathrm{ml}$; final concentration $3 \mu \mathrm{g} / \mathrm{ml}$ ) at room temperature. Following the staining protocol, samples were washed with $1 \mathrm{~mL}$ of nanopure water and vacuum-filter dried. Filters were mounted on glass microscope slides, covered with immersion oil and a coverslip and visualized using an epifluorescent microscope equipped with UV capabilities. 


\subsection{RESULTS}

This section presents the enzyme probe and DNA results for the TA-V groundwater. Section 3.1 presents the results of the enzyme probe (fluorescence data), while Section 3.2 presents the results of the DNA analysis.

\subsection{Enzyme Probe Sample Results}

Table 1 presents the results of the enzyme probe sample analyses. For each result, the sample date, well location, AR/COC number and SNL/NM Sample ID are listed. For the probes, a positive response with the probe and the presence of active enzymes in the sample is designated as yes $(\mathrm{Y})$. A no $(\mathrm{N})$ indicates there was no probe response detected. More details, primarily about the fraction of the total cells that were probe positive, can be found in Appendix A. The DAPI column shows the total number of microorganisms in a given groundwater sample, as determined by DAPI staining.

Table 1. Results of enzyme probe analysis.

\begin{tabular}{|c|c|c|c|c|c|c|c|c|}
\hline \multirow[b]{2}{*}{ Date } & \multirow[b]{2}{*}{ Well Location } & \multirow[b]{2}{*}{ COC \# } & \multirow[b]{2}{*}{ Sample ID } & \multicolumn{3}{|c|}{ Toluene probes ${ }^{a}$} & \multirow{2}{*}{$\begin{array}{c}\text { sMMO probe }^{a} \\
\text { Coumarin } \\
\end{array}$} & \multirow{2}{*}{$\begin{array}{c}\text { DAPI } \\
\text { Cells/mL }\end{array}$} \\
\hline & & & & 3HPA & PA & Cinn & & \\
\hline $11 / 30 / 04$ & TAV-AVN1 & 608050 & 066449-042 & $\mathrm{Y}$ & $\mathrm{Y}$ & $\mathrm{Y}$ & $\mathrm{Y}$ & $1.75 \mathrm{E}+04$ \\
\hline $11 / 30 / 04$ & LWDS-MW2 & 608056 & 066456-042 & $\mathrm{Y}$ & $\mathrm{Y}$ & $\mathrm{Y}$ & $\mathrm{Y}$ & $1.75 E+04$ \\
\hline $12 / 01 / 04$ & TAV-MW4 & 608066 & 066067-042 & $\mathrm{Y}$ & $\mathrm{Y}$ & $\mathrm{N}$ & $\mathrm{Y}$ & $8.75 E+04$ \\
\hline $12 / 01 / 04$ & TAV-AVN2 & 608052 & 066051-042 & $\mathrm{N}$ & $\mathrm{Y}$ & $\mathrm{Y}$ & $\mathrm{Y}$ & $1.40 \mathrm{E}+05$ \\
\hline $12 / 02 / 04$ & TAV-MW5 & 608066 & 066467-042 & $\mathrm{Y}$ & $\mathrm{N}$ & $\mathrm{Y}$ & $\mathrm{Y}$ & $4.20 \mathrm{E}+04$ \\
\hline $12 / 06 / 04$ & TAV-MW3 & 608062 & 066062-042 & $\mathrm{Y}$ & $\mathrm{N}$ & $\mathrm{Y}$ & $\mathrm{Y}$ & $5.25 \mathrm{E}+04$ \\
\hline $12 / 06 / 04$ & TAV-MW8 & 608072 & 066073-042 & $\mathrm{N}$ & $\mathrm{Y}$ & $\mathrm{N}$ & $\mathrm{Y}$ & $3.50 \mathrm{E}+04$ \\
\hline $12 / 07 / 04$ & TAV-MW1 & 608058 & 066458-042 & $\mathrm{Y}$ & $\mathrm{N}$ & $\mathrm{N}$ & $\mathrm{Y}$ & $5.95 \mathrm{E}+04$ \\
\hline $12 / 08 / 04$ & TAV-MW9 & 608074 & 066475-042 & $\mathrm{Y}$ & $\mathrm{Y}$ & Y & $\mathrm{Y}$ & $8.75 E+04$ \\
\hline $12 / 08 / 04$ & LWDS-MW1 & 608054 & 066453-042 & $\mathrm{Y}$ & $\mathrm{Y}$ & $\mathrm{N}$ & $\mathrm{Y}$ & $1.05 \mathrm{E}+05$ \\
\hline $12 / 09 / 04$ & TAV-MW7 & 608070 & 066471-042 & Y & Y & $\mathrm{Y}$ & Y & $2.10 \mathrm{E}+05$ \\
\hline
\end{tabular}




\begin{tabular}{c|c|c|c|c|c|c|c|c}
\hline $12 / 09 / 04$ & TAV-MW6 & 608068 & $066469-042$ & $\mathrm{~N}$ & $\mathrm{Y}$ & $\mathrm{Y}$ & $\mathrm{Y}$ & $1.75 \mathrm{E}+05$ \\
\hline $12 / 14 / 04$ & TAV-MW2 & 608060 & $066460-042$ & $\mathrm{Y}$ & $\mathrm{Y}$ & $\mathrm{N}$ & $\mathrm{Y}$ \\
\hline
\end{tabular}

Figure 2 shows the results of applying enzyme probes to sample TAV-MW5 (Sample ID 066467-042); the figure shows both a negative and positive response to application of the toluene enzyme probes. The micrograph on the left represents the DAPI-stained or total number of microbial cells present in the sample, while the center micrograph represents the cells that transformed the 3HPA probe into a fluorescent product. The right micrograph shows a negative response with the PA probe. 

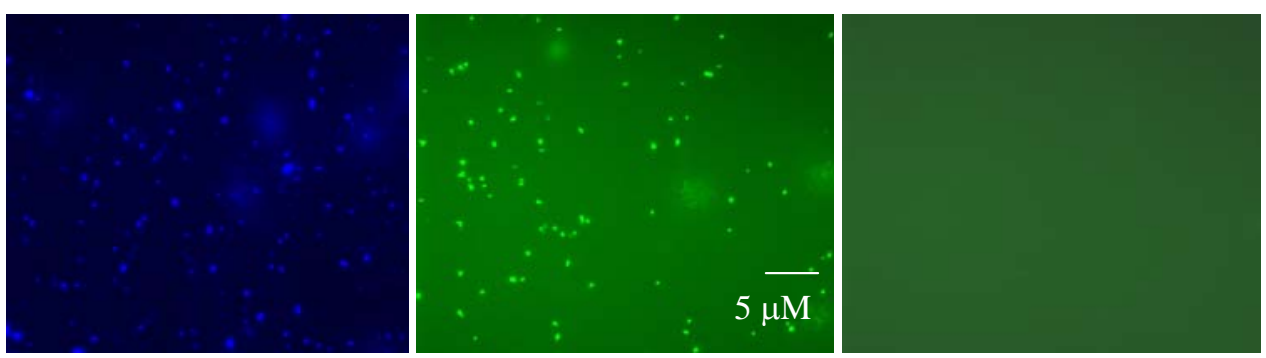

Figure 2. Micrographs of TAV-MW5 (Sample ID 066467-042).

\subsection{DNA Studies}

DNA studies were performed to determine if the genes for the toluene oxygenases or sMMO enzyme were present. The enzyme probes only provide information regarding the activity of the enzyme; if the enzyme is not active, there remains a possibility that the gene is there but not "turned on" and active. Detection of the DNA signal therefore provides context for the enzyme probe results. Table 2 provides the possible combined results and outcomes:

Table 2. Outcome of combining enzyme probe and DNA analysis results.

\begin{tabular}{c|c|l}
$\begin{array}{c}\text { DNA } \\
\text { Analysis }\end{array}$ & $\begin{array}{c}\text { Enzyme } \\
\text { Probes }\end{array}$ & \multicolumn{1}{c}{ Comments } \\
\hline+ & + & $\begin{array}{l}\text { The gene for the enzyme is there and the enzyme is active; TCE is being } \\
\text { cometabolized }\end{array}$ \\
\hline- & + & The gene for the enzyme is not detectable but the enzyme is showing activity \\
\hline- & - & The gene for the enzyme is not there; the enzyme is not active \\
\hline+ & - & $\begin{array}{l}\text { The gene for the enzyme is there but the enzyme is not active; the enzyme is } \\
\text { likely being inhibited by the lack of substrate or inducer }\end{array}$ \\
\hline
\end{tabular}

DNA samples collected from all 13 wells were PCR amplified using both toluene and methane targeted primers. In each case, amplification and visualization of a PCR product provides evidence of the presence, and hence potential, of the gene of interest. The results of the DNA amplification with gene specific primers were variable.

An example of the amplification of the 2, 3, and 4-monoxygenase with the PHE primers from TA-V groundwater is shown in Figure 3. Figure 4 shows amplification of the toluene-3 and -4monooxygenase genes with RMO, Figure 5 shows the toluene-2,3-dioxygenase genes resulting from amplification with the TOD primers, and Figure 6 shows the amplification of the sMMO gene from groundwater. All of these PCRs represent direct amplification of the toluene or sMMO genes from TA-V groundwater. Table 3 provides a summary of these results. A plus sign designates a positive response (i.e., amplification) with a specific set of DNA primers. A blank means that a quantifiable amount of DNA was not amplified. Positive controls with DNA from known toluene or sMMO degraders (laboratory strains) were performed for each of the PCR reactions (data not shown). Negative controls with DNA from E. coli (does not contain any cometabolic genes) were used in each of the reactions (data not shown). Both controls supported the use of the primer sets described above and provided direct evidence that they (primers) targeted a specific gene (sMMO) or multiple genes (toluene oxygenase) as expected. 


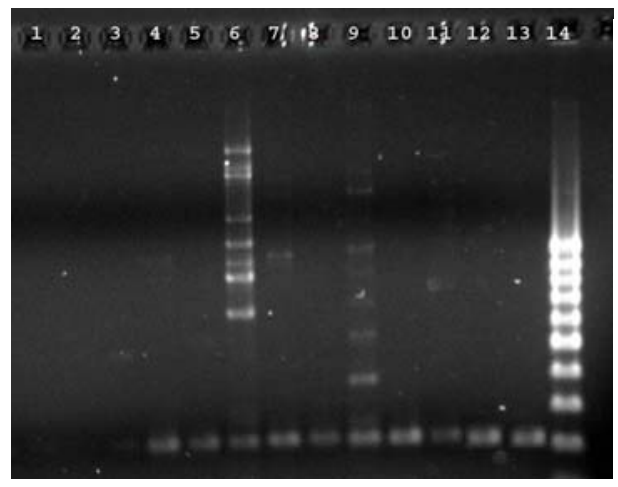
1. TAV-AVN1
2. LWDS-MW1
3. TAV-MW9
4. TAV-MW6
5. TAV-MW7
6. LWDS-MW2
7. TAV-MW2
8. TAV-MW3
9. TAV-AVN2
10. TAV-MW1
11. TAV-MW4
12. TAV-MW5
13. TAV-MW8
14. Ladder

Figure 3. Amplification of toluene genes using the PHE primers.

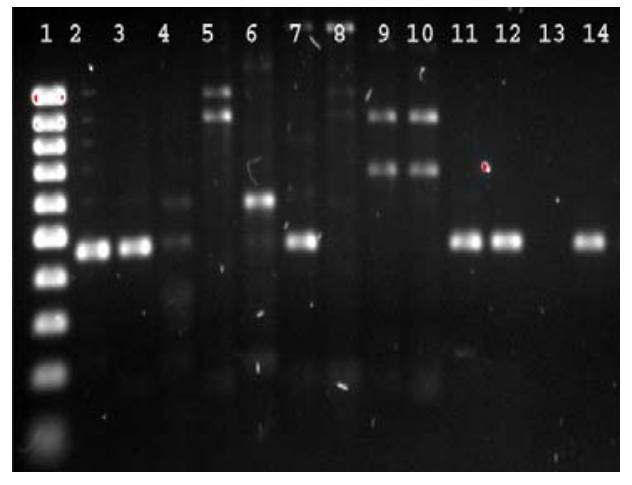
1. Ladder
2. TAV-AVN1
3. LWDS-MW1
4. TAV-MW7
5. LWDS-MW2
6. TAV-MW1
7. TAV-MW8
8. TAV-MW5
9. TAV-MW3
10. TAV-MW4
11. TAV-MW9
12. TAV-MW2
13. TAV-AVN2
14. TAV-MW6

Figure 4. Amplification of toluene genes using the RMO primers.

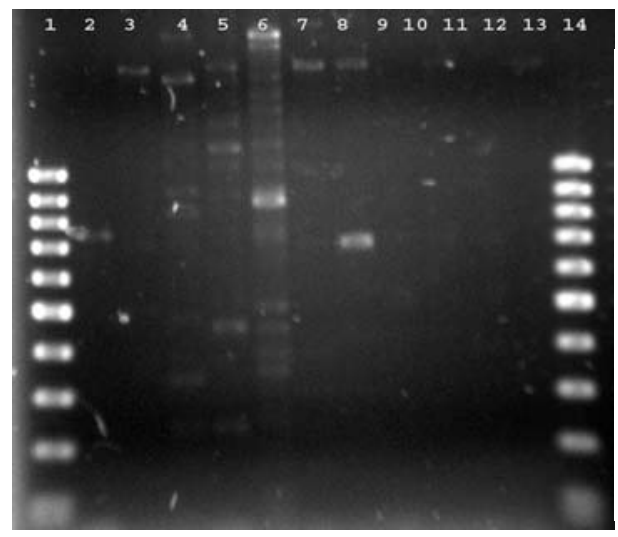
1. Ladder
2. TAV-MW7
3. TAV-MW1
4. TAV-MW3
5. TAV-MW8
6. LWDS-MW1
7. LWDS-MW2
8. TAV-MW9
9. TAV-MW4
10. TAV-MW5
11. TAV-AVN1
12. TAV-AVN2
13. TAV-MW6
14. Ladder

Figure 5. Amplification of toluene genes using the TOD primers. 

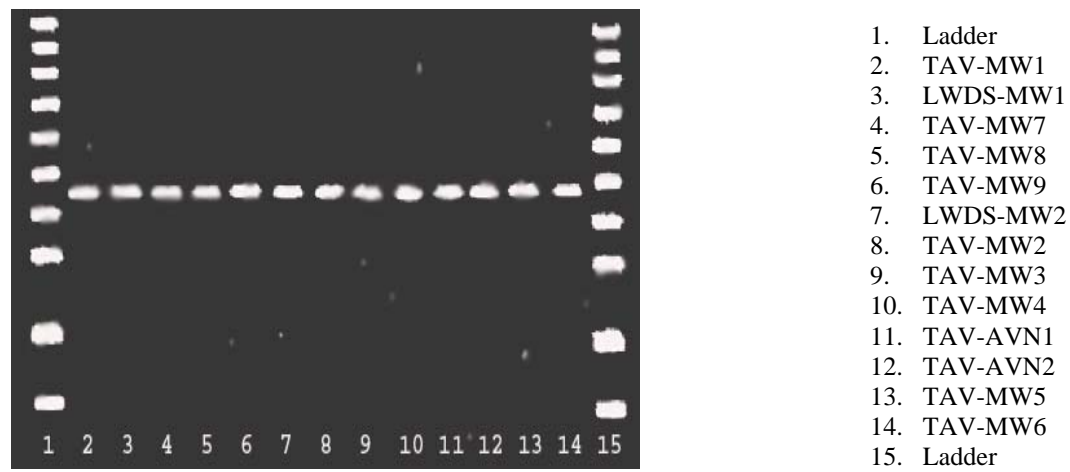

Figure 6. Amplification of sMMO genes.

Table 3. Results of amplification of DNA in groundwater from wells at Sandia TA-V.

\begin{tabular}{|c|c|c|c|c|c|c|c|}
\hline \multirow[b]{2}{*}{ Date } & \multirow[b]{2}{*}{ Well Location } & \multirow[b]{2}{*}{ COC \# } & \multirow[b]{2}{*}{ Sample ID } & \multirow[b]{2}{*}{$\mathrm{sMMO}^{a}$} & \multicolumn{3}{|c|}{ Toluene primers (DNA) } \\
\hline & & & & & $\mathbf{R M O}^{a}$ & TOD $^{a}$ & $\mathrm{PHE}^{a}$ \\
\hline $11 / 30 / 04$ & TAV-AVN1 & 608050 & 066449-042 & + & + & & \\
\hline $11 / 30 / 04$ & LWDS-MW2 & 608056 & 066456-042 & + & & & + \\
\hline $12 / 01 / 04$ & TAV-MW4 & 608066 & 066067-042 & + & & & + \\
\hline $12 / 01 / 04$ & TAV-AVN2 & 608052 & 066051-042 & + & & & + \\
\hline $12 / 02 / 04$ & TAV-MW5 & 608066 & 066467-042 & + & & & + \\
\hline $12 / 06 / 04$ & TAV-MW3 & 608062 & 066062-042 & + & & & + \\
\hline $12 / 06 / 04$ & TAV-MW8 & 608072 & 066073-042 & + & + & & + \\
\hline $12 / 07 / 04$ & TAV-MW1 & 608058 & 066458-042 & + & & & + \\
\hline $12 / 08 / 04$ & TAV-MW9 & 608074 & 066475-042 & + & + & + & \\
\hline $12 / 08 / 04$ & LWDS-MW1 & 608054 & 066453-042 & + & + & & \\
\hline $12 / 09 / 04$ & TAV-MW7 & 608070 & 066471-042 & + & + & + & + \\
\hline $12 / 09 / 04$ & TAV-MW6 & 608068 & 066469-042 & + & + & & + \\
\hline $12 / 14 / 04$ & TAV-MW2 & 608060 & 066460-042 & + & + & & + \\
\hline
\end{tabular}

a- The + designates that DNA was amplified directly from groundwater using the primer listed. 


\subsection{SUMMARY AND CONCLUSIONS}

The purpose of these studies was to investigate biodegradation of TCE in groundwater at TA-V. The main goal was to demonstrate an active aerobic degradation mechanism through the use of enzyme activity probes.

A suite of probes has been developed that indicate activity of enzymes responsible for cometabolic degradation of TCE. Three toluene degradation pathways and the sMMO degradation pathway were evaluated. Enzymes responsible for degradation of these compounds have been shown to cometabolically degrade TCE and have been found in all groundwater systems investigated thus far including the Test Area North site at the Idaho National Laboratory, Technical Area V site at the Sandia National Laboratories, and the Arizona Department of Environmental Quality Park-Euclid WQARF site (Wymore et al., 2004; Clingenpeel et al., 2005b; Howard et al., 2005).

Results for TA-V enzyme probe data demonstrate that toluene oxygenase and sMMO are present and active in all of the wells based on the application of enzyme activity probes to groundwater samples. All 13 of the wells sampled at the TA-V site had a positive response with at least one of the toluene probes. The majority of the wells, 11 out of 13 , showed a positive response with at least two of the three toluene probes, four wells showed a response with all of the toluene probes. Any positive response, even with one probe, provides direct evidence of enzyme activity in the groundwater sample. All of the wells at TA-V showed a positive response with coumarin, the sMMO enzyme activity probe.

DNA results for the sMMO gene showed that all of the wells were positive for the presence of the sMMO gene. However, amplification of the toluene genes was variable. For the majority of the wells, the toluene genes and enzyme activity probe results supported one another, but there were instances when the enzyme probes found activity a nd the DNA analysis was unable to amplify the toluene gene that would be responsible for that activity. Unlike the sMMO, the toluene DNA primers are still in early development stages with respect to application to environmental samples. Toluene and sMMO probe results from groundwater inside and outside the TCE-contaminated area do not differ significantly. All of the groundwater samples showed a response with at least one of the toluene probes and the sMMO probe, suggesting the mechanism for aerobic degradation of TCE is present and active in the entire area sampled (TA-V).

Dissolved oxygen measurements in all TA-V wells averaged 49\% saturation (Orr and Dettmers, 2004), indicating aerobic conditions in the contamination area; these data are consistent with the enzyme probe findings.

The detection of both sMMO and toluene oxygenase enzyme activity, as determined by enzyme activity probes, in TA-V groundwater samples implicate cometabolism as a mechanism of natural attenuation. A widespread positive response (all of the TA-V groundwater samples) to the coumarin (sMMO) assay demonstrates that indigenous methanotrophs are actively expressing the sMMO enzyme; this activity alone is more than sufficient evidence of the cometabolic activity at this site. Active enzymes were found throughout the tested area, including samples taken from both inside and outside the area of contamination, defined as $<5$ ppb TCE concentration (Figure 1), demonstrating that the process is not driven by constituents in the contaminated groundwater, but by the presence of the enzymes and oxygen. These data provide conclusive evidence of active enzyme systems capable of TCE degradation at TA-V and more importantly, represent an active mechanism for the natural attenuation of contaminants. 


\subsection{REFERENCES}

10. Alexander, M. (1967). In “Agriculture and the Quality of Our Environment” (N.C. Brady, ed.), American Association for the Advancement of Science, Washington D.C., pp. 331-342.

11. Alvarez-Cohen, L., and McCarty, P. L. (1991). "Effects of toxicity, aeration, and reductant supply on trichloroethylene transformation by a mixed methanotrophic culture." Appl. Environ. Microbiol., 57, 228-235.

12. Baldwin, B. R., Nakatsu, C. H., and Nies, L. (2003). "Detection and enumeration of aromatic oxygenase genes by multiplex and real-time PCR." Appl. Environ. Microbiol., 69(6), 33503358.

13. Brockman, F. J. (1995). "Nucleic-acid based methods for monitoring the performance of in situ bioremediation." Molecular Ecology, 4, 567-578.

14. Clingenpeel, S. R., Keener, W. K., Keller, C. R., De Jesus, K., Howard, M. H., and Watwood, M. E. (2005). "Activity-dependent fluorescent labeling of bacterial cells expressing the TOL pathway." Journal of Microb. Meth., 60, 41-46.

15. Clingenpeel, S.R., Howard, M.H., Wymore, R.A., Sorenson, K.S, and Watwood, M.E. (2005b). "Evaluation of Enzyme Activity Probes for Detection of Contaminant-Degrading Microorganisms in Trichloroethylene-Contaminated Groundwater at Three Field Sites.” Abstr. $105^{\text {th }}$ Gen. Meet. Am. Soc. Microbiol., O-004.

16. Ensley, B. D. (1991). "Biochemical diversity og trichloroethylene metabolism." Annu. Rev. Microbiol., 45, 283-299.

17. Fogel, M. M., Taddeo, A. R., and Fogel, S. (1986). "Biodegradation of chlorinated ethenes by a methane-utilizing mixed culture." Appl. Environ. Microbiol., 51, 720-724.

18. Fries, M. R., Forney, L. J., and Tiedje, J. M. (1997). "Phenol- and Toluene-degrading microbial populations from an aquifer in which successful trichloroethene cometabolism is observed." Appl. Environ. Microbiol., 63(4), 1523-1530.

19. Howard, M.H., Clingenpeel, S.C., Leiser, O.P. and Watwood, M.E. (2005). "Molecular and Physiological Characterization of Aerobic TCE Degradation Potential.” Eighth International In Situ and On-Site Bioremediation Symposium. Battelle Press, Columbus, OH.

20. Kauffman, M. E., Keener, W. K., Watwood, M. E., and Lehman, R. M. (2003). "Use of 3hydroxyphenylacetylene for activity-dependent, fluorescent labeling of bacteria that degrade toluene via 3-methylcatechol.” Journal of Microb. Meth. 55, 801-805.

21. Keener, W. K., Watwood, M. E., and Apel, W. A. (1998). "Activity-dependent fluorescent labeling of bacteria that degrade toluene 2,3-dioxygenase." Applied Microbiology and Biotechnology, 49, 455-462. 
22. Keener, W. K., Watwood, M. E., and Apel, W. A. (1997). Probes for enzyme-dependent fluorescent labeling of bacteria degrading trichloroethylene, Battelle Press, Columbus, Ohio.

23. Little, C. D., Palumbo, A. V., Herbes, S. E., Lidstom, M. E., Tyndall, R. L., and Gilmer, P. J. (1988). "Trichloroethylene biodegradation by a methane-oxidizing bacterium." Appl.

Environ. Microbiol., 951-956.

24. Madsen, E. L. (1998). "Epistemology of environmental microbiology." Environmental Science and Technology, 32, 429-539.

25. Madsen, E. L. (1991). "Determining in situ biodegradation: facts and challenges." Environ. Sci. Technol., 25, 1662-1673.

26. McDonald, I. R., Kenna, E. M., and Murrell, J. C. (1995). "Detection of methanotrophic bacteria in environmental samples with PCR." Appl. Environ. Microbiol, 61(1), 116-121.

27. Mesarch, M. B., Nakatsu, C. H., and Nies, L. (2000). "Development of Catechol 2,3dioxygenase-specific primers for monitoring bioremediation by competitive quantitative PCR." Appl. Environ. Microbiol., 66(2), 678-683.

28. Miller, A. R., Keener, W. K., Watwood, M. E., and Roberto, F. F. (2002). "A rapid fluorescence-based assay for detecting soluble methane monooxygenase." Applied Microbiology and Biotechnology, 58, 183-188.

29. NMED, 2004, "Compliance Order on Consent Pursuant to the New Mexico Hazardous Waste Act 74-4-10: Sandia National Laboratories Consent Order,” New Mexico Environment Department, April 29, 2004.

30. Oldenhuis, R., Oedzes, J. Y., Waarde, J. J. v. d., and Janssen, D. B. (1991). "Kinetics of chlorinated degradation by Methylosinus trichosporium OB3b and toxicity of trichloroethylene." Appl. Environ. Microbiol, 57, 7-14.

31. Oldenhuis, R. R. L., Vink, J. M., Jannsen, D. B., and Wiltholt, B. (1989). "Degradation of chlorinated aliphatic hydrocarbons by Methylosinus trichosporium OB3b expressing soluble methane monooxygenase." Appl. Environ. Microbiol, 55, 2819-2826.

32. Orr, B.R. and Dettmers, D.L. (2004). "Current conceptual model of groundwater flow and contaminant transport at Sandia National Laboratories/New Mexico Technical Area V,", SAND2004-11470, Sandia National Laboratories, New Mexico.

33. Parales, R. E., Ditty, J. L., and Harwood, C. S. (2000). "Toluene-degrading bacteria are chemotactic towards the environmental pollutants benzene, toluene, and trichloroethylene." Appl. Environ. Microbiol., 66(9), 4098-4104.

34. Pfiffner, S. M., Phelps, T. J., Palumbo, A. V., and Hazen, T. C. (1997). "The effects of nutrient dosing on subsurface methanotrophic populations and TCE degradation capabilities." Journal of Industrial Microbiology, 18, 204-212. 
35. Semprini, L., Roberts, P.V., Hopkins, G.D., McCarty, P.L., 1990, “A Field Evaluation of In-Situ Biodegradation of Chlorinated Ethenes: Part 2, Results of Biostimulation and Biotransformation Experiments," Ground Water, Vol. 28, No. 5, pp. 715-727.

36. SNL/NM, 2004a, "Corrective Measures Evaluation Work Plan Technical Area-V Groundwater,” SAND2004-1471, Sandia National Laboratories/New Mexico.

37. Speitel, G. E., and Alley, E. R. (1991). "Bioremediation of unsaturated soils contaminated with chlorinated solvents." Journal of Hazardous Materials, 28, 81-90.

38. Tsien, H.-C., Brusseau, G. A., Hanson, R. S., and Wackett, L. P. (1989). "Biodegradation of trichloroethylene by Methylosinus trichosporium OB3b." Appl. Environ. Microbiol, 55(12), 3155-3161.

39. Wackett, L.P. (1984). “P.h.D. Dissertation” The University of Texas, Austin.

40. Wilson, J.T. and Wilson, B.H. (1985). "Biotransformation of Trichloroethylene in soil." Appl. Environ. Microbiol, 49, 242-243.

41. Wymore, R.A., Harris, K.L., and Sorenson, K.S. (2004). "Final Quick Win Vertical Profile Sampling Report” NEW-ID-2003-046, Revision 0, North Wind, Inc. 
Appendix A

Enzyme Probe Data

E-22 
Table A-1. Results of toluene enzyme activity probe application at TA-V.

\begin{tabular}{c|c|c|c|c|c|c}
\hline \multicolumn{1}{c}{} & \multicolumn{3}{c}{ Toluene Probes $^{a}$} \\
\hline Date & Well Location & COC \# & Sample ID & 3HPA & PA & Cinn \\
\hline $11 / 30 / 04$ & TAV-AVN1 & 608050 & $066449-042$ & ++ & ++ & ++++ \\
\hline $11 / 30 / 04$ & LWDS-MW2 & 608056 & $066456-042$ & +++ & ++ & +++ \\
\hline $12 / 01 / 04$ & TAV-MW14 & 608066 & $066067-042$ & ++ & + & - \\
\hline $12 / 01 / 04$ & TAV-AVN2 & 608052 & $066051-042$ & - & + & ++ \\
\hline $12 / 02 / 04$ & TAV-MW5 & 608066 & $066467-042$ & +++ & - & ++ \\
\hline $12 / 06 / 04$ & TAV-MW3 & 608062 & $066062-042$ & + & - & ++ \\
\hline $12 / 06 / 04$ & TAV-MW8 & 608072 & $066073-042$ & - & +++ & - \\
\hline $12 / 07 / 04$ & TAV-MW1 & 608058 & $066458-042$ & + & - & - \\
\hline $12 / 08 / 04$ & TAV-MW9 & 608074 & $066475-042$ & +++ & +++ & +++ \\
\hline $12 / 08 / 04$ & LWDS-MW1 & 608054 & $066453-042$ & ++ & +++ & - \\
\hline $12 / 09 / 04$ & TAV-MW7 & 608070 & $066471-042$ & ++ & + & ++ \\
\hline $12 / 09 / 04$ & TAV-MW6 & 608068 & $066469-042$ & - & + & + \\
\hline $12 / 14 / 04$ & TAV-MW2 & 608060 & $066460-042$ & + & + & - \\
\hline
\end{tabular}

$a$ - The number of plus signs designated the percentage of positive response resulting from each probe. For example, a single plus sign indicates that between $10-25 \%$ of the total cells in the sample demonstrated a clear quantifiable response when exposed to that particular probe; Two plus signs represents $25-50 \%$; three, $50-75 \%$; and four $75-100 \%$ of the total microbial population were probe positive, verifying enzyme activity. A minus sign indicates that no enzyme activity was determined; no fluorescence was detected. 
This Page Intentionally Left Blank

E-24 


\section{Distribution:}

\section{External:}

Joe Rothermel (6)

North Wind, Inc.

1425 Higham Street

Idaho Falls, ID 83405

Robert Ferry (1)

CE2 Corporation

2702 Gelding Lane

Livermore, CA 94551

Karren Suesz (4)

DOE/SNL Community Resources Information Office c/o Epsilon Systems Solutions

2017 Yale Boulevard SE, Suite E

Albuquerque, NM 87106

\section{Kim Ong (1)}

316 Dartmouth SE

Albuquerque, NM 87106

Internal:

$\begin{array}{llll}1 & \text { MS-0750 } & \text { P. Brady } & 6118 \\ 1 & \text { MS-1042 } & \text { F. Lauffer } & 6331 \\ 1 & \text { MS-1087 } & \text { S. Griffith } & 6146 \\ 1 & \text { MS-0754 } & \text { S. Collins } & 6118 \\ 1 & \text { MS-1087 } & \text { T. Jackson } & 6146 \\ 1 & \text { MS-1087 } & \text { M. Skelly } & 6146 \\ 10 & \text { MS-1089 } & \text { M. Bachicha } & 6031 \\ & & & \\ 2 & \text { MS-0899 } & \text { Technical Library } & 9616 \\ 1 & \text { MS-9018 } & \text { Central Tech Files } & 8945-1\end{array}$

